VILNIAUS GEDIMINO TECHNIKOS UNIVERSITETAS

Luiza USEVIČIŪTÉ

\title{
LIGNOCELIULIOZINĖS \\ ŽEMATEMPERATŪRĖS BIOANGLIES HIDROFILIŠKUMO DIDINIMO TYRIMAI IR TECHNOLOGIJOS KÜRIMAS
}

DAKTARO DISERTACIJA

TECHNOLOGIJOS MOKSLAI, APLINKOS INŽINERIJA (T 004)

Vilnius, 2021 
Disertacija rengta 2017-2021 metais Vilniaus Gedimino technikos universitete.

\section{Vadovai}

prof. dr. Edita BALTRÉNAITÉ-GEDIENĖ (Vilniaus Gedimino technikos universitetas, aplinkos inžinerija - T 004) (2017-09-01-2020-03-11; 2021-0115-2021-08-31),

prof. habil. dr. Pranas BALTRĖNAS (Vilniaus Gedimino technikos universitetas, aplinkos inžinerija - T 004) (2020-03-12-2021-01-14).

Vilniaus Gedimino technikos universiteto Aplinkos inžinerijos mokslo krypties disertacijos gynimo taryba:

\section{Pirmininkas}

dr. Jurgita MALAIŠKIENĖ (Vilniaus Gedimino technikos universitetas, aplinkos inžinerija - T 004).

Nariai:

dr. Abhishek DUTTA (Izmiro technologijos institutas, chemijos inžinerija T 005),

dr. Dalia FEIZIENE (Lietuvos agrarinių ir miškų mokslų centras, agronomija A 001),

doc. dr. Aušra MAŽEIKIENĖ (Vilniaus Gedimino technikos universitetas, aplinkos inžinerija - T 004),

doc. dr. Rasa VAIŠKŪNAITĖ (Vilniaus Gedimino technikos universitetas, aplinkos inžinerija - T 004).

Disertacija bus ginama viešame Aplinkos inžinerijos mokslo krypties disertacijos gynimo tarybos posėdyje $2021 \mathrm{~m}$. lapkričio $12 \mathrm{~d}$. 10 val. Vilniaus Gedimino technikos universiteto senato posédžių salëje.

Adresas: Sauletekio al. 11, LT-10223 Vilnius, Lietuva.

Tel.: (8 5) 274 4956; faksas (8 5) 270 0112; el. paštas doktor@ vilniustech.lt

Pranešimai apie numatomą ginti disertaciją išsiųsti $2021 \mathrm{~m}$. spalio $11 \mathrm{~d}$.

Disertaciją galima peržiūrèti Vilniaus Gedimino technikos universiteto talpykloje http://dspace.vgtu.lt ir Vilniaus Gedimino technikos universiteto bibliotekoje (Saulètekio al. 14, LT-10223 Vilnius, Lietuva).

Vilniaus Gedimino technikos universiteto 2021-044-M mokslo literatūros knyga doi:10.20334/2021-044-M

(C) Vilniaus Gedimino technikos universitetas, 2021

(C) Luiza Usevičiūtè, 2021

luiza.useviciute@vilniustech.lt 
VILNIUS GEDIMINAS TECHNICAL UNIVERSITY

Luiza USEVIČIŪTÉ

\section{INVESTIGATIONS AND TECHNOLOGY DEVELOPMENT OF HYDROPHILICITY ENHANCEMENT OF LIGNOCELLULOSIC LOW TEMPERATURE BIOCHAR}

DOCTORAL DISSERTATION

TECHNOLOGICAL SCIENCES,

ENVIRONMENTAL ENGINEERING (T 004)

Vilnius, 2021 
Doctoral dissertation was prepared at Vilnius Gediminas Technical University in 2017-2021.

\section{Supervisors}

Prof. Dr Edita BALTRĖNAITĖ-GEDIENĖ (Vilnius Gediminas Technical University, Environmental Engineering - T 004) (2017-09-01-2020-03-11; 2021-01-15-2021-08-31),

Prof. Dr Habil. Pranas BALTRÉNAS (Vilnius Gediminas Technical University, Environmental Engineering - T 004) (2020-03-12-2021-01-14).

The Dissertation Defence Council of Scientific Field of Environmental Engineering of Vilnius Gediminas Technical University:

\section{Chairman}

Dr Jurgita MALAIŠKIENĖ (Vilnius Gediminas Technical University, Environmental Engineering - T 004).

\section{Members:}

Dr Abhishek DUTTA (Izmir Institute of Technology, Chemical Engineering T 005),

Dr Dalia FEIZIENE (Lithuanian Research Centre for Agriculture and Forestry, Agronomy - A 001),

Assoc. Prof. Dr Aušra MAŽEIKIENĖ (Vilnius Gediminas Technical University, Environmental Engineering - T 004),

Assoc. Prof. Dr Rasa VAIŠKŪNAITĖ (Vilnius Gediminas Technical University, Environmental Engineering - T 004).

The dissertation will be defended at the public meeting of the Dissertation Defense Council of Environmental Engineering in the Senate Hall of Vilnius Gediminas Technical University at 10 a. m. on 12 November 2021.

Address: Saulètekio al. 11, LT-10223 Vilnius, Lithuania.

Tel.: +370 5274 4956; fax +370 5270 0112; e-mail: doktor@ vilniustech.lt

A notification on the intend defending of the dissertation was send on 11 October 2021.

A copy of the doctoral dissertation is available for review at Vilnius Gediminas Technical University repository http://dspace.vgtu.lt and at the Library of Vilnius Gediminas Technical University (Sauletekio al. 14, LT-10223 Vilnius, Lithuania). 


\section{Reziumè}

Disertacijoje aprašoma bioanglies fizikinių ir cheminių savybių priklausomybė nuo pirolizès temperatūros, laiko ir pradinès žaliavos. Tiriamas ryšys tarp bioanglies drékumo bei kitų jos fizikinių ir cheminių savybių. Vertinama, kaip kinta bioanglies drèkumas po jos modifikacijos skirtingų tirpalų garais. Teoriškai ir eksperimentiškai analizuojamas skysčių kapiliarinis pakilimo aukštis esant skirtingiems pradinių žaliavų, drėkumo ir dalelių dydžio bioanglies tipams.

Disertaciją sudaro įvadas, trys skyriai, bendrosios išvados ir rekomendacijos, naudotos literatūros ir autoriaus publikacijų disertacijos tema sąrašai, priedai.

Ivadiniame skyriuje aptariama tiriamoji problema, darbo aktualumas, tyrimų objektas, formuluojamas darbo tikslas ir uždaviniai, aprašoma tyrimų metodika, darbo mokslinis naujumas, darbo rezultatų praktinè reikšmè, pateikiami ginamieji teiginiai. Ivado pabaigoje pristatomos disertacijos tema autoriaus paskelbtos publikacijos ir pranešimai konferencijose, pateikiama disertacijos struktūra bei pareiškiamos padèkos.

Pirmasis skyrius skirtas mokslinès literatūros analizei. Jame pateikiama informacija apie fundamentinę bioanglies ir vandens sąveiką, ją lemiančius veiksnius, skirtingus bioanglies sudrèkimo vertinimo metodus, oro taršą lakiaisiais organiniais teršalais, biofiltracijos būdą užterštam orui valyti, drègmės itaką biofiltrų veikimui, kapiliarumo reiškinių deformuojamoje poringojoje medžiagoje ir mišinių teorinius modelius. Skyriaus pabaigoje formuluojamos išvados ir tikslinami disertacijos uždaviniai.

Antrajame skyriuje aprašoma atliktų tyrimų metodologija. Pristatyti metodai, kuriais vertinamos bioanglies fizikinès ir cheminès savybès, analizuojamas bioanglies drèkumas remiantis vandens lašelio skverbimosi laiko testu, etanolio lašelio molingumo testu bei kontakto laipsnio analize, nagrinèjama bioanglies modifikacija gamtos procesais pagrịstais būdais bei jos fizikinių ir cheminių savybių pokyčiai, nustatoma modifikuotos bioanglies geba šalinti lakiuosius organinius ir neorganinius teršalus biofiltracijos sistemoje, ịvertinama bioanglies geba didinti smèlingojo rudžemio fizikines ir chemines savybes. Skyriaus pabaigoje suformuotos išvados.

Trečiasis skyrius skirtas atliktų tyrimų rezultatams apibendrinti, ryšiams tarp skirtingų bioanglies savybių atskleisti bei bioanglies naudojimo biofiltracijos sistemoje ir dirvožemyje galimybėms įvertinti. Visų tyrimų rezultatai lyginti su kitų autorių darbais. Rezultatų skyrius baigiamas išvadomis. 


\section{Abstract}

The dissertation describes dependence of biochar's physical-chemical properties on pyrolysis temperature, holding time, and primary feedstock. The connection between biochar wettability and its physical-chemical properties was analysed. It was shown how biochar wettability alters after its modification with steam of different solutions. Height of solutions capillary rise of biochar (in the case of different sizes of particles, primary feedstock, and wettability) was analysed theoretically and experimentally.

The dissertation consists of an introduction, three chapters, general conclusions and recommendations, references, as well as a list of the author's publications and annexes.

Introduction consists of the research problem, relevance of the thesis, the research object, wordings of the aim and objectives of the thesis. It also includes scientific novelty and practical value of the thesis, presents the defended propositions. At the end of the introduction, the author's publications on the topic of the dissertation as well as the structure of the dissertation and acknowledgements are provided.

The first chapter is dedicated to the review of scientific literature. Fundamental interaction of biochar with water as well as the controlling factors, various methods for determination of biochar wettability, application of biochar in biofiltration technology, effect of moisture content on biofilters' operation, mathematical models of capillarity phenomena in deformable porous media and mixture theoretical models. At the end of the chapter, the conclusions are drawn and the objectives of the thesis are revised.

The second chapter is devoted to the description of the research methodology. It presents methods used to evaluate physico-chemical properties of biochar, biochar wettability according to water drop penetration time test, the molarity of ethanol droplet test and contact angle analysis, modification of biochar by naturebased methods, and evaluation of changes in physico-chemical properties, modified biochar's ability to remove volatile organic and inorganic contaminants in the biofiltration system, its ability in enhancing physical-chemical properties in sandy loam. Conclusions are made at the end of the chapter.

The third chapter deals with summarizing the results of the research, revealing the relationships between different biochar's properties and its application in the biofiltration system and soil. The results of all studies are compared with the works of other authors. The section of conclusion sums up the key findings. 


\section{Simboliai}
$A \quad-$ medžiagos skerspjūvio plotas, $\mathrm{cm}^{2}$
$C \quad-\quad$ energijos paradimo koeficientas, $\mathrm{J} / \mathrm{m}$
$g \quad-$ laisvasis kritimo pagreitis, $\mathrm{m} / \mathrm{s}^{2}$
$G_{m} \quad-\quad$ vamzdelio masè, $\mathrm{g}$
$h \quad-\quad$ kapiliarinio kilimo aukštis, $m$
$K \quad-$ medžiagos laidumas, $\mathrm{m}^{2}$
$m \quad$ - medžiagos masė skysčio kapiliarinio kilimo metu, g
$P_{c} \quad-\quad$ kapiliarinis slègis, $\mathrm{N} / \mathrm{m}^{2}$
$r \quad-\quad$ kapiliaro spindulys, $\mathrm{m}$
$R \quad-\quad$ vamzdelio spindulys, $\mathrm{m}$
$r_{h} \quad-$ hidraulinis kapiliaro spindulys, $\mathrm{m}$
$r_{s} \quad-\quad$ išbrinkusio kapiliaro spindulys, $m$
$S_{w f} \quad-$ galutinė medžiagos prisotinimo būsena
$S_{w i} \quad-$ pradinè medžiagos prisotinimo būsena
$u \quad-\quad$ tūrinis vidutinis Darsi greitis, $\mathrm{m} / \mathrm{s}$ 


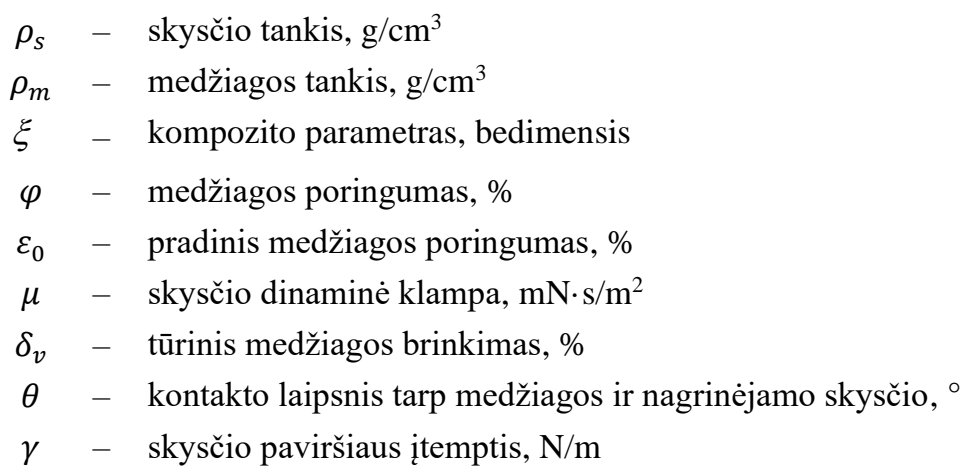

\section{Santrumpos}

$\begin{array}{ll}\text { BET } & - \text { Braunauer, Emmerr ir Teller } \\ \text { BMR } & - \text { branduolio magnetinis rezonansas } \\ \text { CTAB } & - \text { cetiltrimetilamonio bromidas } \\ \text { EBS } & - \text { Europinis bioanglies sertifikatas } \\ \text { ELM } & - \text { etanolio lašelio molingumo testas } \\ \text { GCL } & - \text { greitojo ciklo laukas } \\ \text { MEK } & - \text { metiletilketonas } \\ \text { NPK } & - \text { natrio, fosforo ir kalio trąšos } \\ \text { PCP } & - \text { pentachlorofenolis } \\ \text { PDP } & - \text { porų dydžio pasiskirstymas } \\ \text { PSO } & - \text { Pasaulio sveikatos organizacija } \\ \text { SEM } & - \text { skenuojančioji elektronų mikroskopija } \\ \text { VSG } & - \text { vandens laikomoji geba } \\ \text { VLSL } & - \text { vandens lašelio skverbimosi laiko testas } \\ \text { XSD } & - \text { X spindulių difrakcija }\end{array}$

\section{Apibrëžtys}

Absorbcija - procesas, kurio metu viena medžiaga (absorbatas) sulaikoma kitos (absorbento) (PAC, 1990).

Adsorbcija - ištirpusios medžiagos koncentracijos padidejimas, esant kondensuotos ir skystosios fazès sąsajai, dèl paviršiaus jègų veikimo (PAC, 1990).

Bioanglis - heterogeniškas junginys, sudarytas iš aromatinès anglies ir mineralų; gaminama pirolizès būdu iš tvariais būdais gautos biomasės kontroliuojamomis sąlygomis (EBC, 2012). 
Biofiltras - oro valymo įrenginys, kuriame aktyviąją biomasę laiko inertinis užpildas (Daukšas et al., 2003).

Biomasè - mikroorganizmų, augalų ir gyvūnų gaminama biomasė (PAC, 1992).

Bioplèvele - mikroorganizmų apaugos arba sluoksnelis reaktoriaus ar biofiltro inertinès ikrovos paviršiuje (Daukšas et al., 2003).

Biotechnologija - gamtos ir inžinerijos mokslų integracija dèl organizmų, ląstelių, molekulių ir jų dalių panaudojimo prekèms ir paslaugoms (PAC, 1992).

Cheminis modifikavimas - procesas, kurio metu bent viena polimero cheminès sandaros dalis pakeičiama cheminèmis reakcijomis (PAC, 2004).

Fizikinès savybès - spalva, kietumas, lydymosi bei virimo temperatūra ir kitos savybès, lemiančios medžiagos kokybę ir atskiriančios ją nuo kitų medžiagų (Daukšas et al., 2003). Fizikinis modifikavimas - medžiagų savybių keitimas fizikiniais metodais, pvz., kristalizuojant, maišant su priedais ir pan. (Daukšas et al., 2003).

Funkciné grupé - atomas ar atomų grupé, turinti panašių cheminių savybių (PAC, 1994). Hidrofiliškumas - tendencija, kai molekulè yra tirpinama vandeniu (PAC 1997).

Hidrofobiškumas - medžiagos nesugebèjimas sudaryti molekulinių ryšių su vandens molekulèmis (Daukšas et al., 2003).

I krova - 1) technologiniam procesui paruoštas žaliavų rinkinys; 2) inertiniai kūnai (pvz., keraminiai žiedai), padidinantys fazių sąlyčio paviršių (Daukšas et al., 2003).

Kapiliariniai reiškiniai - reiškiniai, susiję su skysčiu paviršiaus ịtemptimi fazių riboje (Daukšas et al., 2003).

Kapiliarinis slègis - slėgių skirtumas tarp dviejų fazių, kurias kapiliare skiria kreivas paviršius (Daukšas et al., 2003).

Lignoceliuliozine biomase - biomasè, sudaryta iš trijų polimerų (celiuliozès, hemiceliuliozès ir lignino) bei nedidelio kiekio kitų komponentų, pvz., acetilo grupių, mineralų ir fenolinių junginių (Isikgor, Becer, 2015).

Lietaus vanduo - lietaus pavidalu ị žemę patenkantis vanduo, kuris kaupiasi paviršiuje, nuteka ị gruntą ar gilesnius požeminius sluoksnius (Paulauskas et al., 2008).

Paviršiaus aktyvumo medžiaga, PAM - medžiaga, mažinanti terpès, kurioje ji yra ištirpusi, paviršiaus ịtempti (PAC, 1972).

Paviršiaus įtemptis - jèga, mažinanti kūno paviršių (PAC, 1996).

Pirolize - termolizè, paprastai susijusi su aukštos temperatūros poveikiu inertiškoje aplinkoje (PAC, 2007).

Repelentas - atbaidančioji medžiaga (Daukšas et al., 2003).

Sorbcija - procesas, kurio metu medžiaga (sorbatas) sorbuojama (adsorbuojama arba absorbuojama) ant ar kitoje medžiagoje (sorbente) (PAC, 1990).

Žematemperatūré bioanglis - bioanglis, gaminama žemose pirolizès temperatūrose $\left(<500{ }^{\circ} \mathrm{C}\right)$, kurios lemia didesni jos hidrofobiškumo laipsni (Werdin et al., 2020). 



\section{Turinys}

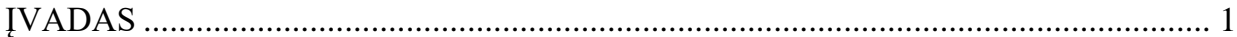

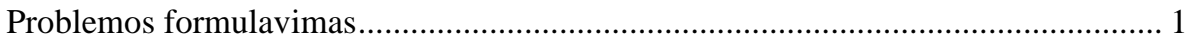

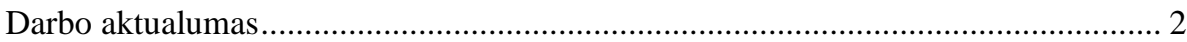

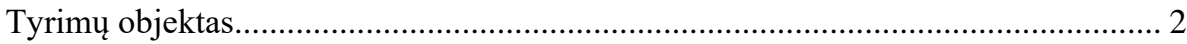

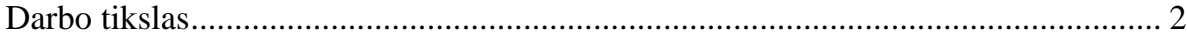

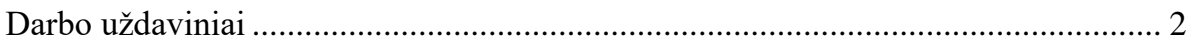

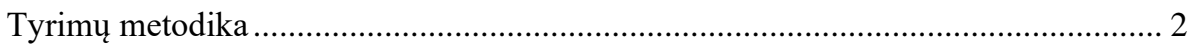

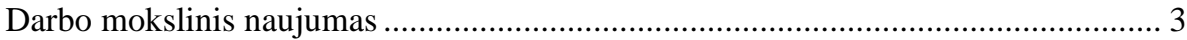

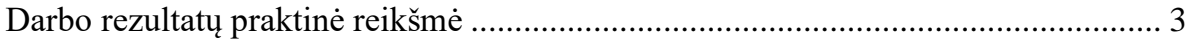

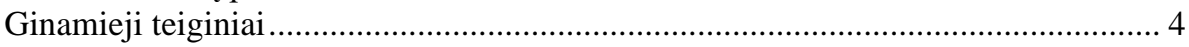

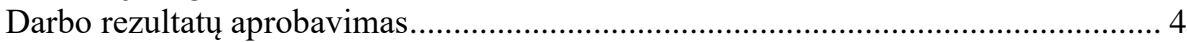

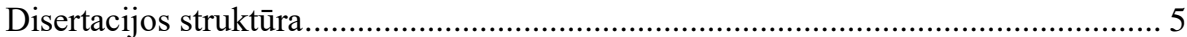

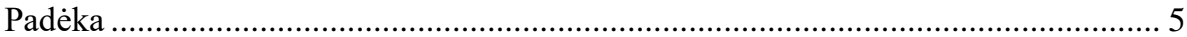


1. LIGNOCELIULIOZINĖS ŽEMATEMPERATŪRĖS BIOANGLIES HIDROFILIŠKUMO DIDINIMAS IR JOS PRITAIKYMAS DIRVOŽEMYJE, ORO

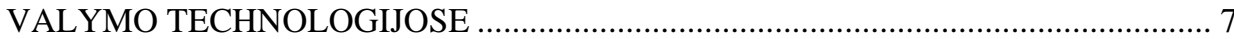

1.1. Bioanglies ir vandeninių tirpalų sąveikos svarba .............................................. 7

1.2. Bioanglies drèkumas ir ji lemiantys veiksniai ................................................... 10

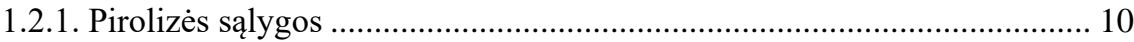

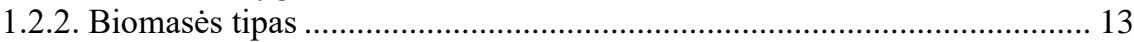

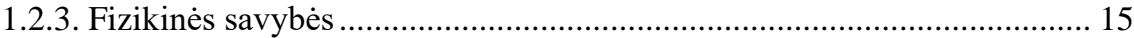

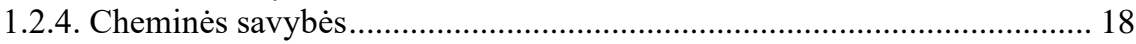

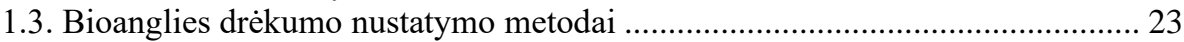

1.4. Biologiniai, fizikiniai ir cheminiai bioanglies modifikacijos büdai................... 27

1.5. Bioanglies naudojimas oro valymo technologijose ……………........................ 29

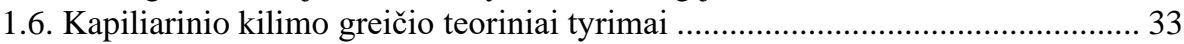

1.7. Kapiliarinio kilimo greičio skaitinis modeliavimas.............................................. 37

1.8. Tvarumo aspektai bioanglies modifikavimo technologijose ............................. 38

1.9. Pirmojo skyriaus išvados ir disertacijos uždavinių formulavimas...................... 40

2. BIOANGLIES FIZIKINIŲ IR CHEMINIŲ SAVYBIŲ NUSTATYMAS, MODIFIKAVIMAS, KAPILIARINIS KILIMAS, NAUDOJIMAS DIRVOŽEMYJE

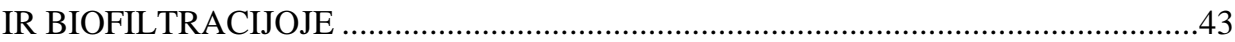

2.1. Kapiliarinio kilimo greičio teoriniai tyrimai ................................................... 44

2.2. Bioanglies drèkumo ryšio su jos fizikinėmis ir cheminėmis savybèmis

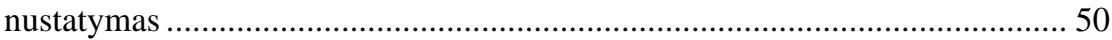

2.3. Bioanglies drékumo ịvertinimas vandens lašelio skverbimosi laiko testu, molingumo testu ir kontakto laipsnio analize ................................................... 54

2.4. Bioanglies modifikacija fizikiniais ir cheminiais metodais .............................. 55

2.5. Bioanglies naudojimas biofitracijos procese lakiesiems teršalams iš oro

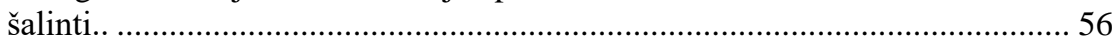

2.6. Bioanglies poveikis dirvožemio cheminių ir hidrofizikinių savybių

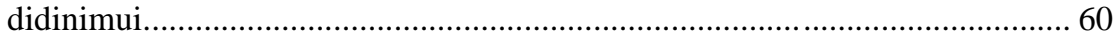

2.7. Kapiliarinio kilimo greičio bioanglyje skaitinis modeliavimas .......................... 63

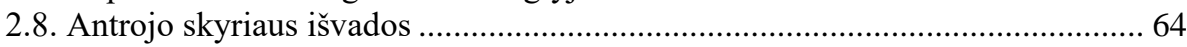

3. BIOANGLIES DRĖKUMO TEORINIŲ IR EKSPERIMENTINIŲ TYRIMŲ

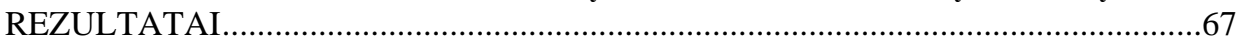

3.1. Kapiliarinio kilimo greičio bioanglyje teoriniai tyrimai .................................... 68

3.2. Bioanglies drèkumo bei kitų jos fizikinių ir cheminių savybių ryšys................. 72

3.3. Bioanglies drèkumas, ịvertintas vandens lašelio skverbimosi laiko testu, etanolio lašelio molingumo testu ir kontakto laipsnio analize ........................... 93

3.4. Bioanglies, modifikuotos fizikiniais ir cheminiais metodais, savybès ............ 100

3.5. Modifikuotos bioanglies įtaka lakiųų teršalų šalinimo efektyvumo

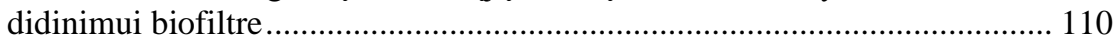

3.6. Trumpalaikè bioanglies geba didinti rudžemio drèkumą .............................. 113

3.7. Kapiliarinio kilimo greičio bioanglyje skaitinio modeliavimo rezultatai ........ 130

3.8. Inžineriniai bioanglies modifikacijos garais sprendimai ................................... 136 
3.9. Trečiojo skyriaus išvados

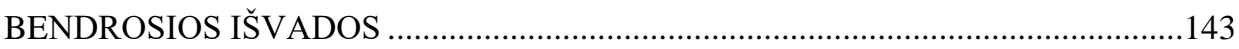

REKOMENDACIJOS ................................................................................... 147

LITERATŪROS SĄRAŠAS ...........................................................................149

AUTORĖS MOKSLINIŲ PUBLIKACIJŲ DISERTACIJOS TEMA SĄRAŠSAS ......163

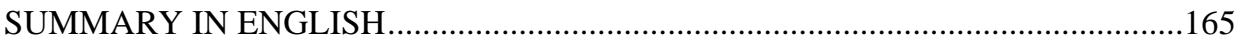

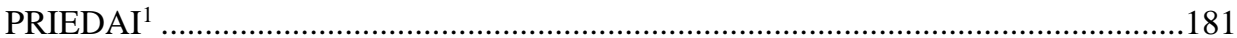

A priedas. Disertacijos autorès sąžiningumo deklaracija ................................... 183

B priedas. Autorès mokslinių publikacijų disertacijos tema kopijos ...................... 184

${ }^{1}$ Priedai pateikiami pridètoje kompaktinèje plokštelèje. 



\section{Contents}

INTRODUCTION

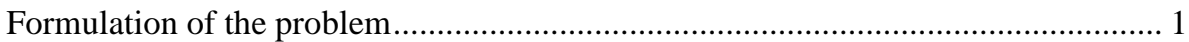

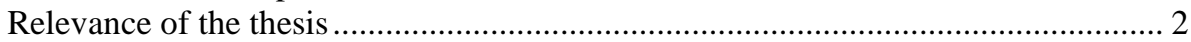

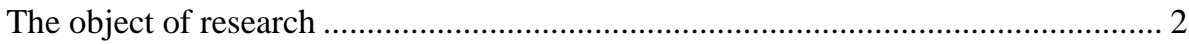

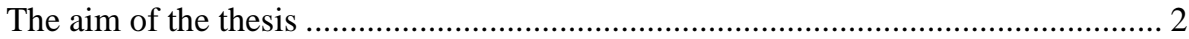

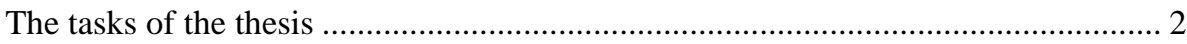

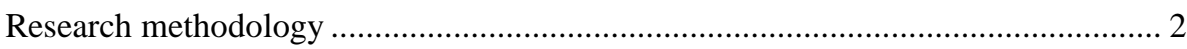

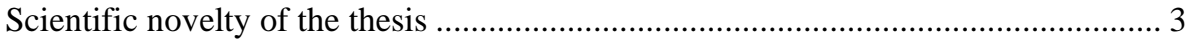

Practical value of the research findings ................................................................. 3

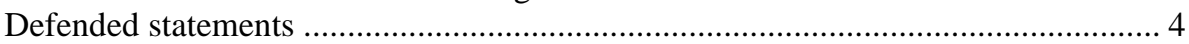

Approval of the research findings ...................................................................... 4

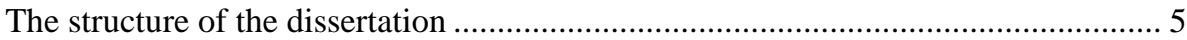

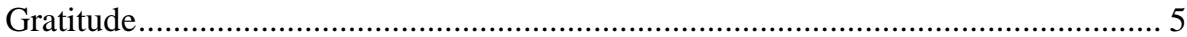

1. INCREASING THE HYDROPHILITY OF LIGNOCELLULOSIS LOW TEMPERATURE BIOCHAR AND ITS APPLICATION IN SOIL, AIR CLEANING

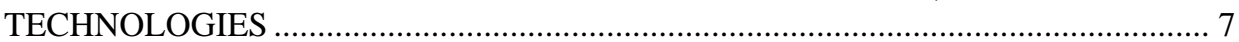

1.1. The importance of the interaction between biochar and water .......................... 7

1.2. Biochar wettability and its factors ................................................................ 10 


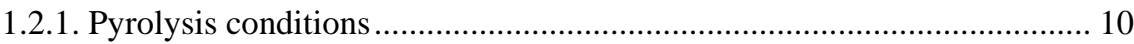

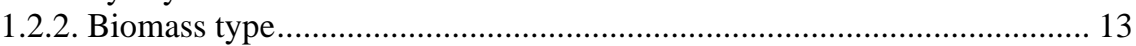

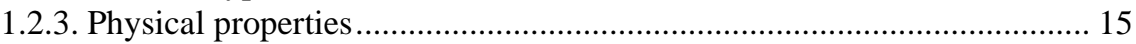

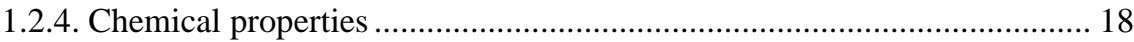

1.3. Methods for the determination of biochar wettability ....................................... 23

1.4. Biological, physical and chemical biochar modification techniques................. 27

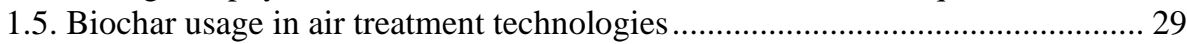

1.6. Theoretical studies of capillary rise height....................................................... 33

1.7. Numerical modelling of capillary rate ............................................................. 37

1.8. Sustainability aspects of biochar modification technologies ............................ 38

1.9. Conclusions of the first chapter and formulation of dissertation tasks .............. 40

2. DETERMINATION OF BIOCHAR PHYSICO-CHEMICAL PROPERTIES, MODIFICATION, CAPILLARY RISE, ITS USAGE IN SOIL AND

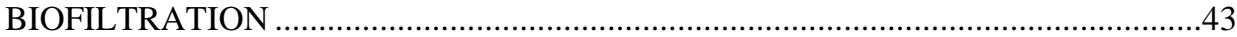

2.1. Theoretical studies of capillary rise rate ........................................................ 44

2.2. Determination of biochar wettability relationship with its physico-chemical

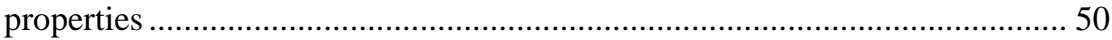

2.3. Estimation of biochar wettability by water droplet penetration time test, molarity of ethanol droplet test and contact angle analysis .............................. 54

2.4. Modification of biochar by physico-chemical methods ................................... 55

2.5. Usage of biochar in biofiltration to remove volatile pollutants from the air .... 56

2.6. Effect of biochar on increasing soil physico-chemical properties ...................... 60

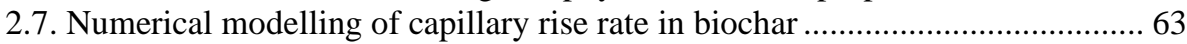

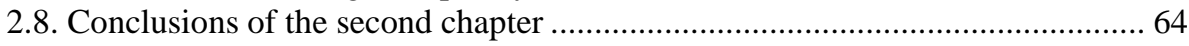

\section{RESULTS OF THEORETICAL AND EXPERIMENTAL INVESTIGATIONS OF}

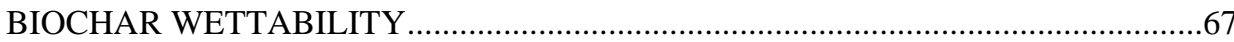

3.1. Theoretical studies of capillary rise rate in biochar........................................ 68

3.2. Relationship between biochar wettability and its other physicochemical

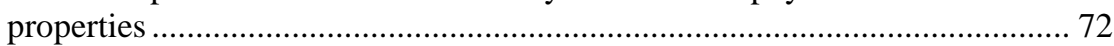

3.3. Biochar wettability assessed by the water droplet penetration time test, ethanol droplet molarity test and contact angle analysis.................................. 93

3.4. Properties of biochar modified by physico-chemical methods........................ 100

3.5. Influence of modified biochar on the increase of volatile pollutant removal

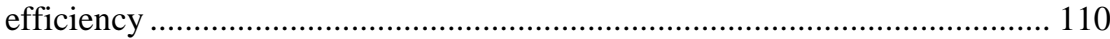

3.6. Short-term effect of biochar ability to increase hydro-physico-chemical

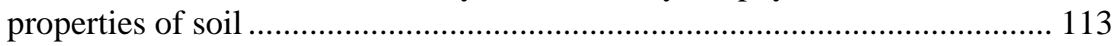

3.7. Results of numerical modelling of capillary rise rate in biochar ..................... 130

3.8. Engineering solutions for biochar modification with steam ........................... 136

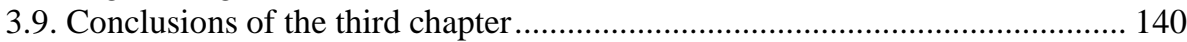

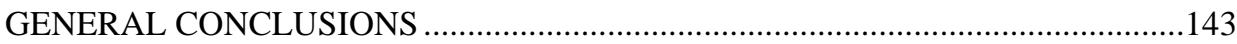

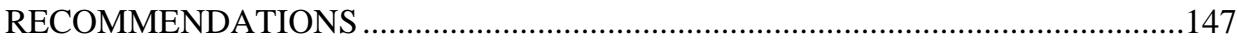


THE LIST OF SCIENTIFIC PUBLICATIONS BY THE AUTHOR ON THE

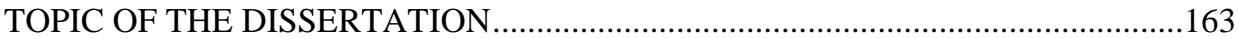

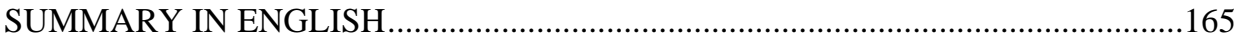

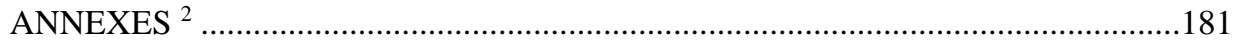

Annex A. Declaration of academic integrity ........................................................... 183

Annex B. Copies of the scientific publications by the author on the topic of the

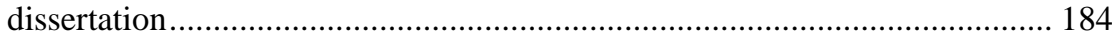

${ }^{2}$ The annexes are supplied in the enclosed compact disc. 



\section{Ivadas}

\section{Problemos formulavimas}

Su vandens sąveika susiję fenomenai, kurie vyksta tik hidrofiliniuose paviršiuose, buvo neseniai pastebėti ir ant bioanglies paviršių. Bioanglis, kaip ir juodoji anglis, pagaminta iš miško kirtimo atliekų, yra natūraliai hidrofobiška. Bioanglies hidrofobiškumas gali neleisti vandeniui prasiskverbti i jos vidines poras. Taip pat bioanglies hidrofobiškumas nèra pastovus. Nustatyta, kad nors bioanglis pasižymi pradiniu hidrofobiškumu, praèjus tam tikram laiko tarpui (vieneriems metams), ji gali virsti hidrofiline (remiantis kontakto laipsnio sumažèjimu iki 69,5 \%). Todèl bioanglies drèkumo savybès nèra pastovios laiko atžvilgiu ir dar nèra gerai suprastos.

Bioanglis, pagaminta aukštesneje kaip $500{ }^{\circ} \mathrm{C}$ temperatūroje, yra hidrofiliškesnè nei pagaminta žemesnèje. Kita vertus, bioanglies gaminimas aukštose temperatūrose yra energiniu ir sąnaudų požiūriu brangus procesas. Dèl šios priežasties yra poreikis gaminti bioangli kuo mažesnèse pirolizės temperatūrose bei mažinti energijos sąnaudas intensyviam pirolizès procesui, kuris naudojamas gaminti bioangli, pasižyminčią didele sorbcijos geba vandens atžvilgiu. 


\section{Darbo aktualumas}

Nuo praeito dešimtmečio pradžios vis daugiau mokslininkų atlieka bioanglies tyrimų atsižvelgiant i jos panaudojimą dirvožemyje anglies sekvestracijai, šiltnamio efektą sukeliančių dujų mažinimui, atsinaujinančioje energetikoje, atliekų mažinime ir dirvožemio gerinime. Šiuo metu ji plačiai tyrinejjama dẻl jos pritaikymo žemės ūkyje, dẻl kurio padideja javų derlius, gerejja naudingosios dirvožemio savybės ir padideja atmosferinès anglies sekvestracija. Ateityje aktuali bioanglies tyrimų sritis gali būti jos ekotoksikologinis poveikis, bioanglies maistinių medžiagų ir kenksmingujų junginių pernešimas, pradinès žaliavos ir pirolizès sąlygų poveikis pagrindinèms bioanglies savybėms.

Reikia gauti daugiau žinių apie pageidautinų savybių bioanglies kūrimą, atsižvelgiant i pradinę žaliavą ir pirolizès procesus. Bioanglies poveikis dirvožemio aplinkai, įtraukiant jo fizikines ir chemines savybes, vis dar nèra gerai suprastas, todèl būtina atlikti daugiau tyrimų.

\section{Tyrimu objektas}

Darbo tyrimų objektas - hidrofobinès žematemperatūrès $\left(450{ }^{\circ} \mathrm{C}\right)$ lignoceliuliozinès bioanglies sąveika su vandeniniais tirpalais.

\section{Darbo tikslas}

Šio darbo tikslas - ịvertinti žematemperatūrès lignoceliuliozinès bioanglies ir tirpalų sąveiką jos hidrofiliškumui didinti.

\section{Darbo uždaviniai}

Darbo tikslui pasiekti reikia spręsti šiuos uždavinius:

1. Sudaryti modifikuotą Luko ir Vašburno modelį organinių ir neorganinių skysčiu kapiliarinio kilimo greičiui lignoceliuliozinèje bioanglyje ịvertinti.

2. Nustatyti lignoceliuliozinès bioanglies, pagamintos žematemperatūrès $\left(300-500{ }^{\circ} \mathrm{C}\right)$ pirolizès sąlygomis, fizikines ir chemines savybes bei jų ryši su drèkumu ir vandens laikomaja geba. 
3. Pritaikyti medžiagos drèkumo įvertinio metodus žematemperatūrei lignoceliuliozinei bioangliai.

4. Sukurti bioanglies hidrofiliškumo didinimo i̧renginį ir sumažinti žematemperatūrès bioanglies $\left(450^{\circ} \mathrm{C}\right)$ hidrofobiškumą gamtos procesais pagrịstais būdais (lietaus vandens garais, ramnolipidinès medžiagos tirpalo garais).

5. Palyginti modifikuotos ir nemodifikuotos bioanglies poveiki lakiụjų organinių ir neorganinių teršalų šalinimo efektyvumui biofiltre su kapiliarine drèkinimo sistema.

6. İvertinti dirvožemio, pagerinto lignoceliuliozine bioanglimi, hidrofiliškumo pokyčius lauko sąlygomis.

7. Taikant modifikuotus Luko ir Vašburno bei multifazès tekejjimo poringaja medžiaga modelius, ivvertinti vandens kapiliarinio kilimo greitị lignoceliuliozinèje bioanglyje.

\section{Tyrimų metodika}

Atliekant bioanglies hidrofiliškumo didinimo teorinius, eksperimentinius ir skaitinio modeliavimo tyrimus, buvo taikytos metodikos, kuriomis eksperimentiškai ịvertintas skysčių kapiliarinio kilimo greitis bioanglies įkrovose (remiantis modifikuotu Luko ir Vašburno modeliu, Brooks ir Corey modeliu bei Darsi dèsniu), taip pat bioanglies fizikinès ir cheminès savybès priklausomai nuo kaitinimo temperatūros ir laiko, drèkumas (taikant vandens lašelio skverbimosi laiko testą, etanolio molingumo testą, kontakto laipsnio analizę), analizuoti bioanglies savybių pokyčiai po jos modifikavimo fizikiniais (ramnolipidinio tirpalo garais ir lietaus vandens garais) ir cheminiais (azoto tirpalu) metodais, ivertinta bioanglies geba šalinti lakiuosius organinius ir neorganinius teršalus biofiltre bei didinti dirvožemio hidrofizikines ir chemines savybes.

\section{Darbo mokslinis naujumas}

Suformuotas bioanglies drèkumo nustatymo metodas. Modifikuotas matematinis modelis skysčiu kapiliarinio greičio prognozei bioanglyje, ịtraukiant tūrinị bioanglies brinkimą ir išbrinkusio kapiliaro spindulį. 


\section{Darbo rezultatų praktinè reikšmė}

Žematemperatūrè pušies medienos bioanglis yra tinkama lakiujų neorganinių teršalų šalinimo efektyvumui biofiltre ir vandens sulaikymui smëlingo lengvojo priemolio rudžemyje didinti. Aukštesnè nei $500^{\circ} \mathrm{C}$ pirolizès temperatūra tinkama bioanglies dideliam savitajam paviršiaus plotui ir hidrofiliškumui sukurti. Beržo medienos ir kanapių bioanglies tipai lemia hidrofiliškos bioanglies pasigaminimą nuo $300{ }^{\circ} \mathrm{C}$ ir $350{ }^{\circ} \mathrm{C}$.

\section{Ginamieji teiginiai}

1. Medienos bioanglis pasižymi didesniu drèkumu ir vandens laikomaja geba, lyginant su žievès bioanglimi dèl šešiais kartais mažesnio pelenų kiekio, blokuojančio porų ertmę.

2. Bioanglies savitajam paviršiaus plotui padidejus tris kartus, amoniako biofiltracijos išvalymo efektyvumas padideja 18 procentinių vienetų.

3. Nepriklausomai nuo hidrofobiškos bioanglies ịterpimo normos $\mathfrak{i}$ smėlingajị rudžemi, jis išlieka hidrofilinis dẻl paviršiaus hidroksilinių oksidacinių funkcinių grupių.

\section{Darbo rezultatų aprobavimas}

Disertacijos tema yra publikuotos penkios mokslinès publikacijos, kurios įtrauktos ị tarptautinius žurnalus. Trys iš jų išspausdintos tarptautiniuose mokslo žurnaluose, referuojamame Clarivate analytics Web of Science duomenų bazeje, ir dvi mokslinès publikacijos yra paskelbtos tarptautiniuose mokslo žurnaluose, referuojamuose Clarivate analytics Web of Science duomenų bazeje.

Disertacijoje atliktų tyrimų rezultatai buvo paskelbti keturiose respublikinėse konferencijose ir dviejose užsienio konferencijose:

- Respublikinėse jaunujų mokslininkų konferencijose „Mokslas Lietuvos ateitis“, 2018-2021 m. Vilniuje;

- Tarptautinejje mokslinèje konferencijoje "International Conference on Plant Systems Biology and Biotechnology" 2021, Auksinès Smiltys, Bulgarija.

- Tarptautinejje mokslinejje konferencijoje „European Geosciences Union", 2019 m. Vienoje, Austrijoje; 
- Tarptautinejje mokslinejje konferencijoje „Central and Eastern European Conference on Health and the Environment", $2018 \mathrm{~m}$. Krokuvoje, Lenkijoje.

\section{Disertacijos struktūra}

Disertaciją sudaro ịvadas, trys skyriai, bendrosios išvados ir rekomendacijos, literatūros ir autoriaus mokslinių publikacijų disertacijos tema sąrašai. Taip pat yra du priedai.

Darbo apimtis - 181 puslapis, neskaitant priedų, tekste panaudota 31 numeruota formulè, 78 paveikslai ir 32 lentelès. Rašant disertaciją buvo panaudotas 181 literatūros šaltinis.

\section{Padéka}

Visų pirma dėkoju savo vadovams - prof. dr. Editai Baltrènaitei-Gedienei ir prof. habil. dr. Pranui Baltrènui už pagalbą rengiant disertaciją. Už pagalbą atliekant dirvožemio, papildyto bioanglimi, lauko tyrimus, dékoju dr. Daliai Feizienei iš Lietuvos agrarinių ir miškų mokslų centro. Už pagalbą atliekant statistinę duomenų analizę nuoširdžiai dèkoju doc. dr. Rūtai Simanavičienei iš Matematinės statistikos katedros. Taip pat dèkoju doc. dr. Teresei Leonavičienei iš Matematinio modeliavimo katedros už mokslinius patarimus atliekant teorinius tyrimus. Nuoširdžiai dèkoju Latvijos valstybinio medienos chemijos instituto darbuotojams - habil. dr. Galinai Duobelei (Galina Dobele), Aleksandrui Volpertsui (Aleksandrs Volperts) ir dr. Oskarsui Bikovensui (Oskars Bikovens) už šiltą prièmimą ir pagalbą stažuotès metu. 



\section{1}

\section{Lignoceliuliozinės žematemperatūrès bioanglies hidrofiliškumo didinimas ir jos pritaikymas dirvožemyje, oro valymo technologijose}

Skyriuje aptariama bioanglies drèkumo samprata ir procesai, veiksniai, darantys ịtaką jos drèkumui, skirtingi bioanglies drèkumo įvertinimo metodai, oro tarša lakiaisiais organiniais ir neorganiniais teršalais, šių teršalų valymas biofiltracijos metu, biofiltro efektyvumą veikiantys veiksniai, kapiliariniai reiškiniai poringojoje medžiagoje, kapiliarinio kilimo vertinimo lygtys.

Skyriaus tematika kartu su bendraautoriais paskelbti keturi straipsniai (Usevičiūtè, Baltrėnaitè, 2019; Usevičiūtè, Baltrėnaitė 2020; Usevičiūtė, Baltrènaitè-Gedienè, 2020; Usevičiūtè et al., 2021). 


\subsection{Bioanglies ir vandeninių tirpalų sąveikos svarba}

Bioanglies ir vandens sąveika yra svarbi daugelyje procesų, iš kurių praktiniu požiūriu svarbiausi vyksta filtravimo sistemose. Bioanglies pritaikomumą lemia skirtingos jos savybès: didelis paviršiaus plotas, mikroporingumas, adsorbcinè geba ir jonų mainų geba (Oliveira et al., 2017). Bioanglies savybės turi reikšmę jos efektyvumui šalinant teršalus iš vandeninès terpès.

Bioanglies naudojimas yra tvarus pasirinkimas siekiant ilgą laiką išlaikyti dirvožemio derlingumą, ypač smélinguosiuose dirvožemiuose, kur tvari žemdirbystė yra apribota dèl mažos vandens laikomosios gebos bei didelio maistinių medžiagų išsiplovimo. Jos naudojimas smèlinguosiuose dirvožemiuose gali suformuoti patrauklų dirvožemio valdymo būdą, nes ją taikant sumažèja papildomas sintetinių trąšų ir intensyvaus drèkinimo poreikis. Suliman et al. (2017) parodè, kad teigiamas bioanglies poveikis dirvožemio drèkumo didinimui vyksta dẻl jos oksidacijos (oksidacinių funkcinių grupių sukūrimo). Kita vertus, geresnis bioanglies veikimas drèkumo požiūriu vyksta dèl kompleksinio savybių poveikio (pvz., poringumo, rūgštinių funkcinių grupių) ir tai negali būti siejama tik su viena jos savybe. Dél poringos struktūros ir didelio paviršiaus ploto bioanglis naudojama ne tik kaip dirvožemio gerintojas, didinantis derlingumą, bet ir kaip efektyvus vandenyje ištirpusių organinių ir neorganinių teršalų sorbentas (Rao et al., 2017).

Bioanglis naudojama ir vandens filtravimo sistemose. Dél bioanglies gebos šalinti daugelị teršalų iš vandeninio tirpalo ji yra efektyvus adsorbentas (Gwenzi et al., 2017). Buvo įrodyta, kad bioanglis yra efektyvi mažinant vandenyje ištirpusių metalų koncentracijas, organinius junginius, suspenduotas kietąsias medžiagas, todèl ji gali būti naudojama ịvairiuose pramoniniuose procesuose.

Samprata apie vandens ir kietos poringosios medžiagos sąveiką yra svarbus veiksnys efektyvaus produkto gamyboje. Kol kas atlikta mažai tyrimų apie bioanglies ir vandens sąveiką (Gray et al., 2014). Vandens patekimas ị poringają medžiagą priklauso nuo kapiliarinių jègų, kurios gali paskatinti arba trukdyti vandens patekimui i poras. Kapiliarinių jègų stiprumas priklauso nuo terpès paviršiaus cheminių ir fizikinių savybių ir yra apibūdinamas Laplaso lygtimi:

$$
P_{c}=\frac{2 \gamma \cos \theta}{r},
$$

čia $P_{c}$ - diferencialinis kapiliarinis slėgis tarp skysčių ir dujų vidinio paviršiaus, $\mathrm{N} / \mathrm{m}^{2} ; \gamma-$ vandens paviršiaus itemptis, $\mathrm{N} / \mathrm{m} ; \theta$ - kontakto laipsnis, kuris priklauso nuo vidinès energijos ir kietosios medžiagos paviršiaus cheminių savybių; $r$-porų spindulys, $m$. Kapiliarinè jèga yra tiesiogiai proporcinga vandens lašelio ir medžiagos paviršiaus kontakto laipsniui ir atvirkščiai proporcinga poru spinduliui (Das, Sarmah, 2015). Kapiliarinio slègio jègos gali būti teigiamosios 
arba neigiamosios, atsižvelgiant ị paviršiaus savybes: hidrofiliniai paviršiai $\left(<90^{\circ}\right)$ sukuria teigiamaji kapiliarini slègi, dèl ko gerejja vandens patekimas i poras, o hidrofobiniai paviršiai $\left(>90^{\circ}\right)$ sukuria neigiamaji kapiliarinị slègị, dẻl ko trukdomas vandens patekimas ị poras (Gray et al., 2014).

Trys fundamentinès fizinès savybès, besisiejančios su kapiliariniu kilimu, yra svarbios praktiniu požiūriu: 1) didžiausias kapiliarinio kilimo aukštis; 2) kapiliarinio kilimo skysčio laikomoji geba; 3) kapiliarinio kilimo greitis. Kiekvienas iš šių aspektų turi svarbią reikšmę visuminiam inžineriniam neprisotinto dirvožemio / vandens sistemos veikimui ir yra sudètinè dirvožemio porų vandens savybių funkcija (Lu, Likos, 2004). Kapiliarinis aukštis priklauso nuo porų dydžio. Kita vertus, didelès poros neturi didelès gebos sulaikyti vandenį. Dèl šios priežasties smèlingieji dirvožemiai greitai išdžiūsta. Kadangi mikroporos turi didesnę gebą sulaikyti vandenį, molingieji dirvožemiai tendencingai turi didesnę vandens laikomają gebą. Todèl kuo mažesnès poros, tuo aukštesnis kapiliarinis kilimas.

Kontakto laipsnis yra labai svarbus, nes jis parodo, kiek paviršius yra drèkus. Kontakto laipsnis yra skysčio traukos prie kietosios medžiagos paviršiaus indikatorius ir susidaro dèl pusiausvyros balanso tarp adhezinių ir kohezinių jègų. Jango lygtis (Depalo, Santomaso, 2013):

$$
\cos \theta_{E}=\frac{\gamma_{S E}-\gamma_{S L}}{\gamma_{L V}}
$$

Ši lygtis sieja kontakto laipsnị su trimis paviršiaus įtempties jègomis, kurios lemia skysčio lašelio formavimąsi ant plokščiojo gulsčiojo kietosios medžiagos paviršiaus, kaip parodyta 1.1 paveiksle.

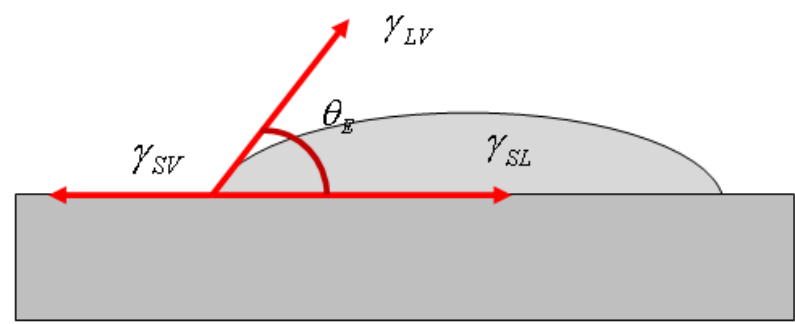

1.1 pav. Pusiausvyros kontakto laipsnis tarp lašelio ir gulsčiojo plokščiojo kietosios medžiagos paviršiaus: $\gamma_{S L}$ - paviršiaus įtempties jèga tarp kietosios medžiagos ir skysčio; $\gamma_{S V}-\operatorname{tarp~kietosios~medžiagos~ir~garų;~} \gamma_{L V}$ - tarp skysčio ir garų (Depalo, Santomaso, 2013)

Fig. 1.1. Equilibrium contact angle between a droplet and a horizontal flat solid surface, where: $\gamma_{S L}-$ surface tension force between solid and liquid; $\gamma_{S V}$ - between solid and vapor; $\gamma_{L V}$ - between liquid and vapor (Depalo, Santomaso, 2013) 
Dvi jègos, lemiančios skysčio kilimą arba nekilimą kapiliaru aukštyn, yra vadinamos adhezinèmis ir kohezinèmis jègomis. Abipusès traukos jègos, egzistuojančios tarp skysčio molekulių, vadinamos kohezija, kuri atsakinga už lašelių susijungimą. Ji lemia paviršiaus ịtempties susidarymą. Kai traukos jẻgos egzistuoja tarp dviejų nepanašių medžiagų, kaip kad skystis ir kietoji medžiaga, jos yra vadinamos adhezija. Jei adhezinès jègos tarp skysčio ir kietosios medžiagos yra didesnès už kohezines jëgas tarp skysčio, tuomet skystis drèkina paviršių. Kapiliarumą lemia vandens molekulių kohezija ir šių molekulių kartu su kietaja medžiaga adhezija.

\subsection{Bioanglies drẻkumas ir jị lemiantys veiksniai}

Aiškus bioanglies ir vandens sąryšio nustatymas yra svarbus jos tolesniam naudojimui. Hidrofiline bioanglis yra tinkamesnè organinių teršalų sorbcijai. Šiuo metu nèra ịvertinti visi veiksniai, skatinantys bioanglies drèkumą. Veiksnių, turinčių įtakos bioanglies ir vandens sąveikai, supratimas leidžia kurti pageidautinų savybių bioanglị. Jos drèkumas gali būti projektuojamas pasirenkant tinkamą pradinę žaliavą ir pirolizès temperatūrą (Kinney et al., 2012). Dažniausiai vartojamas terminas bioanglies hidrofobiškumui ir hidrofiliškumui apibūdinti yra drèkumas (Stevenson, 2016).

\subsubsection{Pirolizès sąlygos}

Pirolizè - biomasės skaidymas esant karščiui ir bedeguonėms sąlygoms (Herath, 2012). Ji gali būti kategorizuojama ị lètąją ir greitają priklausomai nuo kaitinimo greičio ir laiko. Lètoji pirolizè gamina bioanglies tipus, kaitinant biomasę esant mažam greičiui palyginti ilgą laiką (iki kelių dienų). Greitosios pirolizès metu bioanglis gaminama esant dideliam greičiui ir trumpam laikui. Greitoji pirolizė lemia didesni dervų produktyvumą, o lètoji pirolizè lemia didesnị bioanglies produktyvumą (Xiu et al., 2017). Tipinès bioanglies gamybos sąlygos ir jos išeigos esant skirtingiems termocheminiams procesams pateiktos 1.1 lentelëje.

1.1 lentelè. Termocheminiai procesai ir tipinè bioanglies išeiga (Xiu et al., 2017)

Table 1.1. Thermochemical processes and typical biochar yield (Xiu et al., 2017)

\begin{tabular}{|l|l|l|l|}
\hline \multicolumn{1}{|c|}{ Procesas } & \multicolumn{1}{|c|}{ Temperatūra, ${ }^{\circ} \mathrm{C}$} & \multicolumn{1}{|c|}{ Kaitinimo laikas } & \multicolumn{1}{c|}{$\begin{array}{c}\text { Bioanglies išeiga, } \\
\%\end{array}$} \\
\hline Lètoji pirolizè & $400-600$ & $\begin{array}{l}\text { Nuo 3600 s iki } \\
86400 \mathrm{~s}\end{array}$ & $20-50$ \\
\hline Greitoji pirolizė & $400-600$ & $\sim 1 \mathrm{~s}$ & $10-20$ \\
\hline
\end{tabular}


Pirolizės metu medienos biomasės išeigą sudaro trys pagrindiniai produktai: bioanglis, tankios dervos ir dujų mišinys, sudarytas iš anglies oksidų, angliavandenilių ir vandenilio (Solar et al., 2016). Produktų išeiga priklauso nuo proceso sąlygų, o daugiausia - nuo pirolizès reaktoriaus tipo, darbinių sąlygų bei fizikinių ir cheminių biomasès savybių (Nsamba et al., 2015).

Pirolizès metu skaidomi pagrindiniai lignoceliuliozinès biomasès organiniai junginiai, kaip kad celiuliozè $\left(\mathrm{C}_{6} \mathrm{H}_{10} \mathrm{O}_{5}\right)_{\mathrm{n}}$, hemiceliuliozė $\left(\mathrm{C}_{5} \mathrm{H}_{8} \mathrm{O}_{4}\right)_{\mathrm{n}}$ ir ligninas $\left(\mathrm{C}_{10} \mathrm{H}_{12} \mathrm{O}_{3}\right)$ (1.2 pav.). Šių trijų organinių junginių terminio skaidymo greičiai apibrèžiami taip: hemiceliuliozè $>$ celiuliozè $>$ ligninas, todèl galutinių produktų kokybè priklauso nuo žaliavos sudèties. Pirmiausia skaidoma hemiceliuliozė (197$\left.257^{\circ} \mathrm{C}\right)$, po kurios eina celiuliozè $\left(237-347^{\circ} \mathrm{C}\right)$ ir ligninas $\left(277-497^{\circ} \mathrm{C}\right)$.

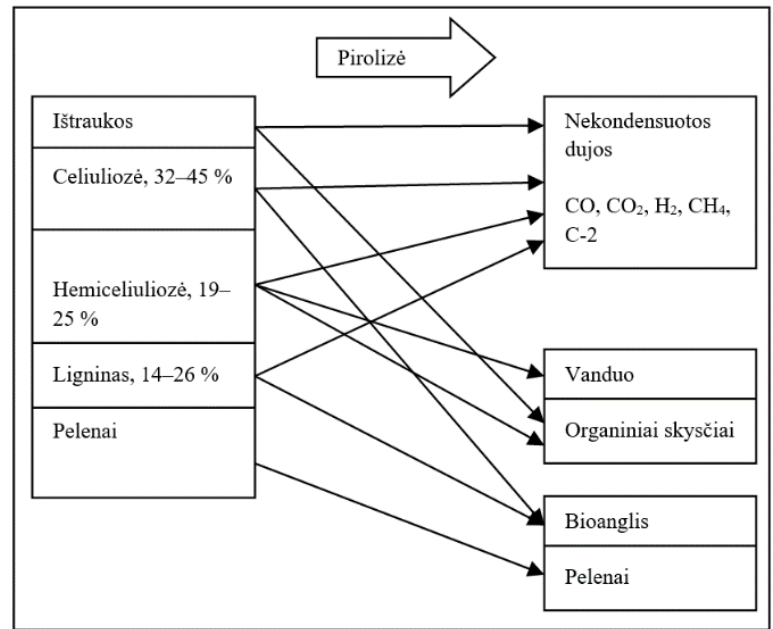

1.2 pav. Supaprastinta biomasès pirolizès schema (Brownsort 2009)

Fig. 1.2. Simplified scheme of biomass pyrolysis scheme (Brownsort 2009)

Tyrimais nustatyta, kad bioanglies drèkumą stipriai veikia pirolizès temperatūra. Viename tyrime (Kinney et al., 2012) bioanglies hidrofobiškumas mažèjo augant produkcijos temperatūrai. Visų žaliavų atveju buvo pastebėtas mažesnis bioanglies hidrofiliškumas esant žemesnèms pirolizès temperatūroms. Remiantis etanolio lašelio molingumo testu (ELM), bioanglies drékumas kito nuo ypač hidrofobiško (ELM = 17, magnolijos lapų bioanglis, $300^{\circ} \mathrm{C}$ ) iki hidrofilinio $\left(\mathrm{ELM}=0\right.$, kukurūzų ir obelų medienos bioanglies tipai, $\left.>500{ }^{\circ} \mathrm{C}\right)$ atvejais $(1.3$ pav.). Kukurūzų ir obelų medienos bioanglies tipai tapo hidrofiliniai $(E L M=0)$ $>400{ }^{\circ} \mathrm{C}$ temperatūroje. Didèjantis bioanglies hidrofiliškumas aukštesnèse produkcijos temperatūrose sudaro galimybes sulaikyti daugiau vandens (Gray et al., 2014). 


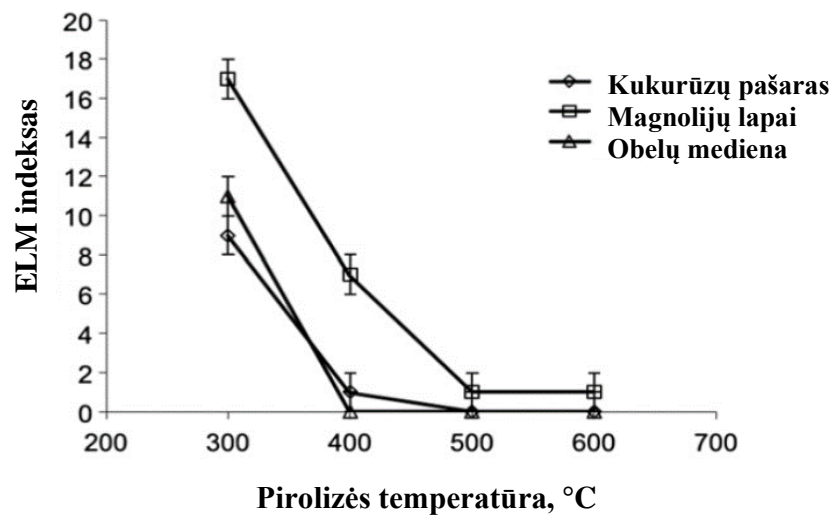

1.3 pav. Bioanglies drèkumo priklausomybè nuo pirolizės temperatūros (Kinney et. al., 2012)

Fig. 1.3. Dependence of biochar wettability on pyrolysis temperature (Kinney et. al., 2012)

Zornoza et al. (2016) tyrè žaliavos savybių, pirolizès temperatūros $(300,400$, 500 ir $\left.700{ }^{\circ} \mathrm{C}\right)$ ir laiko $(1,2,4$ ir 5 val.) poveikị bioanglies stabilumui, maistiniu medžiagu kiekiui ir drèkumui. Temperatūra turèjo ịtakos visoms savybèms, o pirolizès trukmè neturejo jokio poveikio, tik drèkumui bei terminiam stabilumui. Bioanglies tipai, pagaminti $300{ }^{\circ} \mathrm{C}$ temperatūroje, buvo stipriai hidrofobiški (>3600 s), o pasiekus $500{ }^{\circ} \mathrm{C}$ hidrofobiškumas išnyko dèl alifatinių junginių praradimo. Praejus 4 val. javų atliekų bioanglis padidino savo hidrofiliškumo laipsni. Viršijus $500{ }^{\circ} \mathrm{C}$, visi bioanglies tipai tapo hidrofiliški (1.4 pav.).

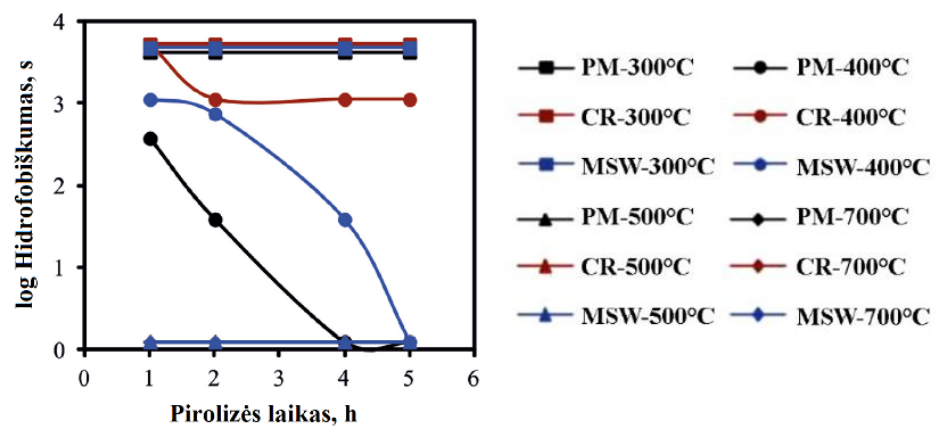

1.4 pav. Ekskrementų, javų atliekų ir komunalinių atliekų bioanglies, pagamintos esant skirtingoms temperatūroms bei kaitinimo laikams, drëkumas (Zornoza et al., 2016)

Fig. 1.4. Wettability of biochar produced from pig excrement, cereal waste, and municipal solid waste at different pyrolysis and heating times (Zornoza et al., 2016) 
Kitame tyrime (Aston et al., 2014) bioanglies drékumui ịtakos turèjo tiek pradinè medžiaga (žilvitinis karklas, drambliažolè, sitkinė eglè), tiek pirolizès temperatūra $\left(350,500,600\right.$ ir $\left.800^{\circ} \mathrm{C}\right)$. Nepriklausomai nuo biomasès, bioanglies hidrofiliškumas didèjo augant temperatūrai. Tai siejama tiek su alkilinių grupių skaidymu, tiek su dalelių susitraukimu pirolizès metu.

\subsubsection{Biomasès tipas}

Biomasè teikia daugelị pranašumų, lyginant su tradiciniu iškastiniu kuru: tai tvarus ir atsinaujinantis energijos šaltinis, lengvai prieinamas daugelyje šalių ir teikiantis neigiamą anglies balansą. Tvari bioanglis gali būti neigiama, kai anglis biomasèje yra transformuojama ị stabilias struktūras, kaip kad bioanglis, kuri gali sekvestruoti anglị dirvožemyje šimtus ar tūkstančius metų. Tai lemia bendros $\mathrm{CO}_{2}$ koncentracijos sumažèjimą atmosferoje, kaip parodyta diagramoje (1.5 pav.).
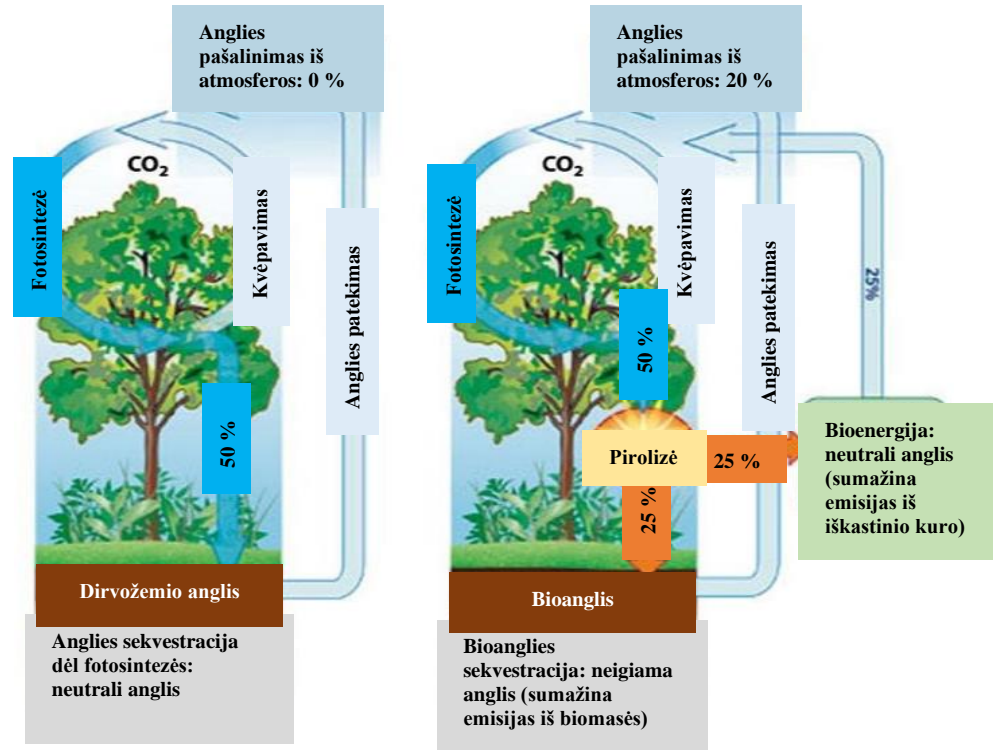

1.5 pav. Neigiamos bioanglies teorija (bioachar-international.org)

Fig. 1.5. Theory of biochar negative (bioachar-international.org)

Kiekvienos biomasès žaliavos savybès yra svarbios pirolizès procesui, ypač tiesioginėms analizėms (pelenų ir drègmès kiekiui), šiluminei vertei, fiksuotos anglies frakcijoms ir lakiesiems komponentams, lignino, celiuliozès, hemiceliuliozès procentinei sudèčiai, neorganinių junginių procentinei sudèčiai, piltiniam ir tikrajam tankiui, dalelių dydžiui. Bioanglies gamybai gali būti naudojamos įvairios biomasès atliekos: energiniai javai, miškininkystės atliekos, 
organinès atliekos, žemès ūkio atliekos, virtuvès atliekos ir nuotekų dumblas. Taigi didesnès išeigos ir poringumo bioanglis gaunama iš biomasès su didesniu lignino ir mažesniu celiuliozès kiekiu (Nartey, Zhao, 2014). Esant aukštoms pirolizès temperatūroms, medienos ir žolinès biomasès dažnai kuria daugiau karbonizuotą bioangli, lyginant su kitomis žaliavomis, kaip kad nuotekų dumblas ar gyvūnų ekskrementai (Suliman et al., 2016).

Per paskutinius dešimtmečius ypatingą dèmesị igauna lignoceliuliozinè biomasè dèl savo gausumo ir lengvo prieinamumo. Lignoceliuliozinę biomasę sudaro miškininkystès atliekos, žoliniai augalai ir aridinių teritorijų augalai (Kumar et al., 2016). Ji sudaryta iš celiuliozès (25-50\%), hemiceliuliozès (15-40\%), lignino (0-40\%), ekstraktų (0-15\%) ir paprastai mažos neorganinių mineralinių medžiagų frakcijos (Kan et al., 2016). Lignoceliuliozinès biomasès fizikinès ir cheminès savybès pateiktos 1.2 lentelèje.

1.2 lentelè. Lignoceliuliozinès biomasès fizikinès-cheminès savybès (Kambo, Dutta, 2015)

Table 1.2. Physico-chemical properties of lignocellulosic biomass (Kambo, Dutta, 2015)

\begin{tabular}{|c|c|c|c|}
\hline Junginys & Celiuliozè & Hemiceliuliozè & Ligninas \\
\hline $\begin{array}{l}\text { Cheminè } \\
\text { struktūra }\end{array}$ & {$[\mathrm{HO}_{\mathrm{OH}}^{\mathrm{OH}} \underbrace{\mathrm{O}_{\mathrm{O}}^{\mathrm{O}}}_{\mathrm{O}_{\mathrm{OH}}^{\mathrm{OO}}} \mathrm{O}$} & OH & 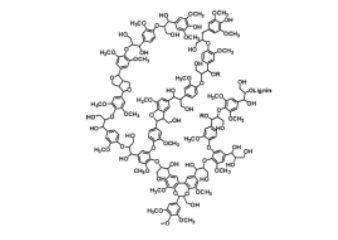 \\
\hline $\begin{array}{l}\text { Molekulinè } \\
\text { formule }\end{array}$ & $\left(\mathrm{C}_{6} \mathrm{H}_{10} \mathrm{O}_{5}\right)_{\mathrm{n}}$ & $\mathrm{C}_{5} \mathrm{H}_{10} \mathrm{O}_{5}$ & $\mathrm{C}_{9} \mathrm{H}_{10} \mathrm{O}_{2}$ \\
\hline \multirow{3}{*}{$\begin{array}{l}\text { Tipinè } \\
\text { biomasès } \\
\text { sudètis }\end{array}$} & $\begin{array}{l}\text { a) kietoji mediena: } \\
39-54 \%\end{array}$ & $\begin{array}{l}\text { a) kietoji mediena: } \\
15-36 \%\end{array}$ & $\begin{array}{l}\text { a) kietoji mediena: } \\
17-29 \%\end{array}$ \\
\hline & $\begin{array}{l}\text { b) minkštoji } \\
\text { mediena: } 41-50 \%\end{array}$ & $\begin{array}{l}\text { b) minkštoji } \\
\text { mediena: } 11-27 \%\end{array}$ & $\begin{array}{l}\text { b) minkštoji mediena: } \\
27-30 \%\end{array}$ \\
\hline & $\begin{array}{l}\text { c) žemės ūkio } \\
\text { augalai: } 24-50 \%\end{array}$ & $\begin{array}{l}\text { c) žemès ūkio } \\
\text { augalai: } 22-35 \%\end{array}$ & $\begin{array}{l}\text { c) žemès ūkio augalai: } \\
7-29 \%\end{array}$ \\
\hline Struktūra & $\begin{array}{l}\text { Homopolimeriniai } \\
\text { D-gliukozės } \\
\text { subvienetai }\end{array}$ & $\begin{array}{l}\text { Ksilozès, manozės, } \\
\text { gliukozès ir } \\
\text { galaktozės } \\
\text { hetropolimeras }\end{array}$ & $\begin{array}{l}\text { Hetropolimeras, } \\
\text { sudarytas iš triju } \\
\text { skirtingų fenil-propano } \\
\text { monomero grupių }\end{array}$ \\
\hline Drèkumas & Vidutinis & Mažas & Didelis \\
\hline
\end{tabular}


Medienos biomasè - svarbiausias šaltinis anglies gamybai pasauliniu mastu. Medienos biomasę sudaro ịvairūs hemiceliuliozès, celiuliozès, lignino ir nedideli kitų organinių ištraukų (pvz., riebalų, fitosterolių ir fenolių) ir neorganinių junginių (kaip kad azoto, fosforo, sieros, silicio bei šarminių žemès metalų ir ịvairių mineralų) kiekiai. Gautos bioanglies struktūra gali kisti priklausomai nuo botaninès rūšies, augalo dalies, dirvožemio tipo, klimato sąlygų ir laiko (Suliman et al., 2016). Medienos biomasès naudojimo potencialas yra didelis dèl palyginti neišnaudotų jos išteklių. Kai kurie tyrëjai apskaičiavo, kad Europoje susidaro $4 \cdot 10^{18} \mathrm{~J} /$ metus medienos biomasès potencialas (beveik $2 \cdot 10^{6} \mathrm{~km}^{2}$ miškų plotas), kuris apima $45 \%$ viso bendro biomasès (medienos ir ne medienos) potencialo tame pačiame regione ir tik $2 \cdot 10^{18} \mathrm{~J} /$ metus viso bendro biomasès potencialo yra panaudojama (Solar et al., 2016).

Taigi bioanglies gamybai gali būti naudojami ịvairūs lignoceliuliozinès biomasès šaltiniai (energiniai javai, miškininkystès atliekos, organinès atliekos, žemès ūkio atliekos ir kt.). Vienas iš svarbesnių bioanglies gamybos šaltinių yra mediena dèl jos didelio naudojimo potencialo. Nustatyta, kad daugiau lignino ir mažiau celiuliozès turinti biomasė yra tinkamesnè didesnio poringumo ir išeigos bioangliai gauti.

\subsubsection{Fizikinès savybès}

Bioanglies savitojo paviršiaus plotas (SPP) ir poringumas yra tarp svarbiausių savybių, lemiančių bioanglies aktyvių vietų kiekybę ir kokybę, todėl yra skatinamos tokios savybès, kaip katijonų mainu geba, vandens laikomoji geba ir adsorbcinė geba. Buvo atlikti tyrimai, kuriais nagrinètas biomasės žaliavos, pirolizès parametrų bei modifikacijos poveikis pageidaujamo bioanglies paviršiaus ploto ir poringumo gamybai. Bioanglis, pagaminta iš didesnio peleningumo žaliavu (ekskrementų), turi mažesnị paviršiaus plotą nei bioanglis, pagaminta iš struktūrizuotos, mažesnio peleningumo žaliavos (Leng et al., 2021). Zhao et al. (2013) nustate, kad iš 12 žaliavų pjuvenos bioanglis, kurios peleningumas mažiausias $(2,8 \%)$, lèmé didžiausią bioanglies SPP $\left(203 \mathrm{~m}^{2} / \mathrm{g}\right)$, o karviụ ekskrementai (peleningumas apie $38 \%)$ lèmé mažiausią SPP $\left(3 \mathrm{~m}^{2} / \mathrm{g}\right)$. Ekskrementų biomase turi didžiausią pelenų kiekį, po kurios eina dumblių biomasè, žolinè ir žemès ūkio atliekų biomasè, medienos ir medienos biomasè.

Didesnè pirolizès temperatūra $\left(>500^{\circ} \mathrm{C}\right)$ siejama su didesniu bioanglies SPP, nes tokiomis sąlygomis formuojama tvarkingesnè struktūra ir didesnis mikroporu $(<1 \mathrm{~nm})$ kiekis, prisidedantis prie didžiosios dalies SPP. Žemose temperatūrose $\left(<500{ }^{\circ} \mathrm{C}\right)$ ir esant dideliems kaitinimo greičiams $\left(30-1000^{\circ} \mathrm{C} / \mathrm{min}\right)$, bioanglies SPP siekia mažiau nei $10 \mathrm{~m}^{2} / \mathrm{g}$. Elnour et al. (2019) nustatè, kad žematemperatūrès palmių bioanglies SPP buvo kur kas mažesnis nei aukštatemperatūrès. $300{ }^{\circ} \mathrm{C}$ ir 
$400{ }^{\circ} \mathrm{C}$ bioanglies SPP buvo gana mažas $\left(2,04\right.$ ir $\left.5,54 \mathrm{~m}^{2} / \mathrm{g}\right)$, o $500{ }^{\circ} \mathrm{C}$ bioanglies jis reikšmingai padidejo ir siekè $124 \mathrm{~m}^{2} / \mathrm{g}$.

Procesai, lemiantys bioanglies SPP didèjimą augant kaitinimo temperatūrai arba kaitinimo greičiui, dar nèra gerai suprasti. Derva, atsirandanti iš pradinès biomasès ląstelinès struktūros, gali užpildyti bioanglies poras žemose kaitinimo temperatūrose, taip mažinant SPP. Dervos komponentai garuoja esant aukštesnèms temperatūroms $\left(650-750^{\circ} \mathrm{C}\right)$, todèl tokiomis sąlygomis poros tampa prieinamos. Viršijus šią temperatūros ribą, bioanglies mikroporų struktūra suyra ir SPP mažeja (Mukherjee, Lal, 2013).

Bioanglies poringumas gali būti klasifikuojamas taip: mikroporos $(<2 \mathrm{~nm})$, mezoporos $(2-50 \mathrm{~nm})$ ir makroporos $(>50 \mathrm{~nm})$, remiantis IUPAC poringuju medžiagų klasifikacine sistema. Remiantis kitais autoriais (Atkinson et al., 2010), bioanglies poringumas yra labai ịvairus ir susideda iš nano- $(<0,9 \mathrm{~nm})$, mikro$(<2 \mathrm{~nm})$ ir makroporu $(>50 \mathrm{~nm})$. Kadangi visų porų dydis yra apribotas nanoskaleje, bioanglies poringumas buvo ivardytas kaip bioanglies nanoporingumas (Lehmann, Joseph, 2009).

Pirolizės temperatūra laikoma dominuojančiu parametru, darančiu ịtaką bioanglies paviršiaus plotui ir poringumui (Leng et al., 2021). Didesnès temperatūros skatina lakiosios medžiagos išgaravimą, taip skatinant erdvių tarp poru susidarymą. Vieno tyrimo rezultatai parode (Gray et al., 2014), kad vandens patekimas i bioangli priklausé tiek nuo pradinès žaliavos, kuri reguliuoja makroporingumą, tiek nuo produkcijos temperatūros, kuri kontroliuoja drékumą ir pirogeninių nanoporu formavimąsi. Didejjant produkcijos temperatūrai, makroporingumas išliko palyginti pastovus, o pirogeninis nanoporingumas gerokai padidèjo (1.6 pav.).

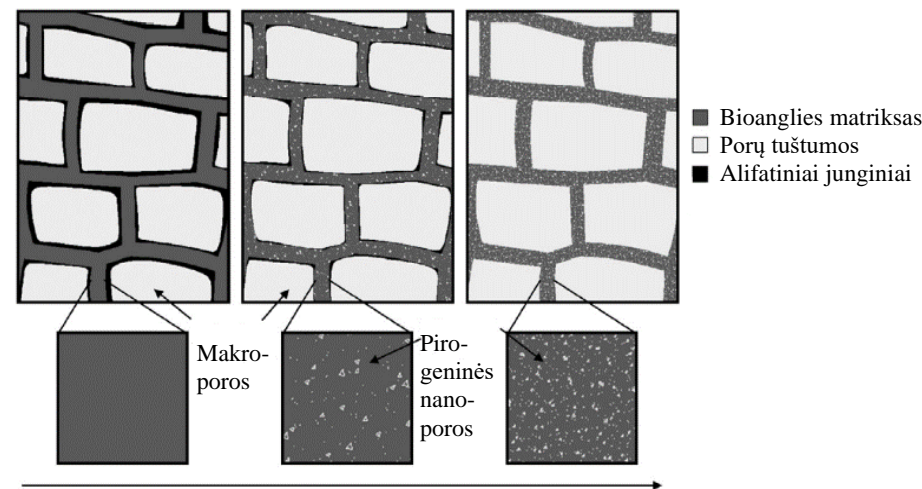

Produkcijos temperatūros didèjimas

1.6 pav. Fizikinis porų modelis (Gray et al., 2014)

Fig. 1.6. Physical pore model (Gray et al., 2014) 
Morfologinė biomasès struktūra yra glaudžiai susijusi su porų išsivystymu ir lemia porų formas (Leng et al., 2021). Medienos bioanglis pasižymi vamzdinėmis porų struktūromis, kurios susidaro dèl jos pradinès žaliavos medienos indų. Remiantis SEM nuotraukomis (Komkiene, Baltrenaite, 2016), matyti, kad karščiu paveikta mediena išlaikè savo pradinę porų struktūrą (1.7 pav.). Paprastosios pušies (Pinus sylvestris) bioanglies mėginių poringumas labai nereikšmingai skyrèsi lètosios ir greitosios pirolizès atvejais. Karpotojo beržo (Betula pendula) mėginių, pagamintų lètosios pirolizès būdu, didžiausias poringumas buvo $8,4 \%$ didesnis nei mèginių, pagamintų greitosios pirolizès būdu. Karpotojo beržo bioanglies poru struktūra reikšmingai skyrèsi nuo paprastosios pušies bioanglies mėginių. Tiek poringumas, tiek porų paviršiaus plotas buvo mažesni. Paprastosios pušies ir karpotojo beržo bioanglies mėginius sudare didelio (40-80) $\mu \mathrm{m}$ ir mažo (5-10) $\mu \mathrm{m}$ skersmens poros, kurių ilgis buvo didesnis nei skersmuo ir sieké $<1000 \mu \mathrm{m}$.
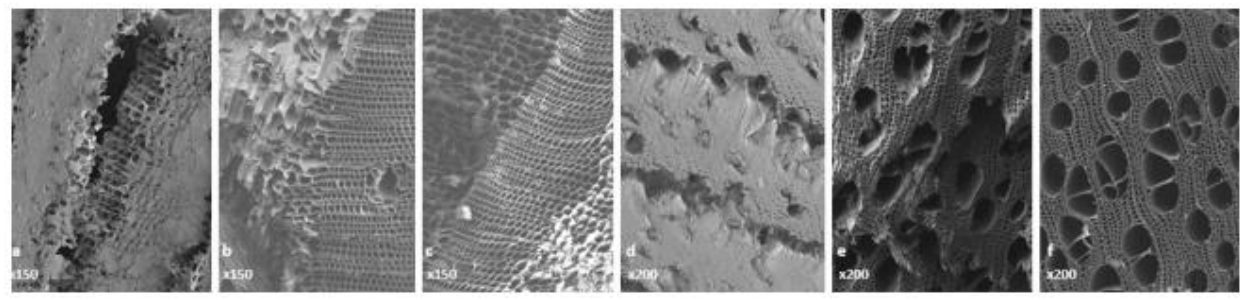

1.7 pav. Žaliavos ir bioanglies nuotraukos, gautos naudojantis skenuojančiu elektroniniu mikrosopu: a) pušies mediena; b) pušies medienos bioanglis (lètoji pirolizè); c) pušies medienos bioanglis (greitoji pirolizė); d) beržo mediena; e) beržo medienos bioanglis (lètoji pirolizè); beržo medienos bioanglis (greitoji pirolizè)

(Komkiene, Baltrenaite, 2016)

Fig. 1.7. Feedstock and biochar images obtained using a scanning electron microscope:

a) pine wood; b) pine wood biochar (slow pyrolysis); c) pine wood biochar (fast pyrolysis); d) birch wood; e) birch wood biochar (slow pyrolysis); birch wood biochar (fast pyrolysis) (Komkiene, Baltrenaite, 2016)

Kitame tyrime (Brewer et al., 2014) bioanglies poringumas daugiausia priklausė nuo pradinès žaliavos (medienos < žolių) ir nežymiai didejo augant pirolizès temperatūrai (1.8 pav.). Bioanglies tipų poringumas kito nuo 0,55 iki 0,86 . Poringumo skirtumai tarp žaliavų siejami su dalelių dydžio skirtumais ir formų pasiskirstymu medienos ir žoliniuose augaluose, nes didžioji dalis pirminès augalo struktūros išsilaiko bioanglyje po pirolizès. Spejjama, kad poringumo didejjimas augant pirolizès temperatūrai vyksta dèl lakiụjų junginių pasišalinimo iš porų ir išliekančios skeletinès struktūros. Bioanglies paviršiaus plotas ir poringumas lemia svarbų poveiki jos pritaikymui. Bioanglis dažnai veikia kaip sorbentas ir jos sorbciné geba stipriai koreliuoja su paviršiaus plotu ir poringumu. 


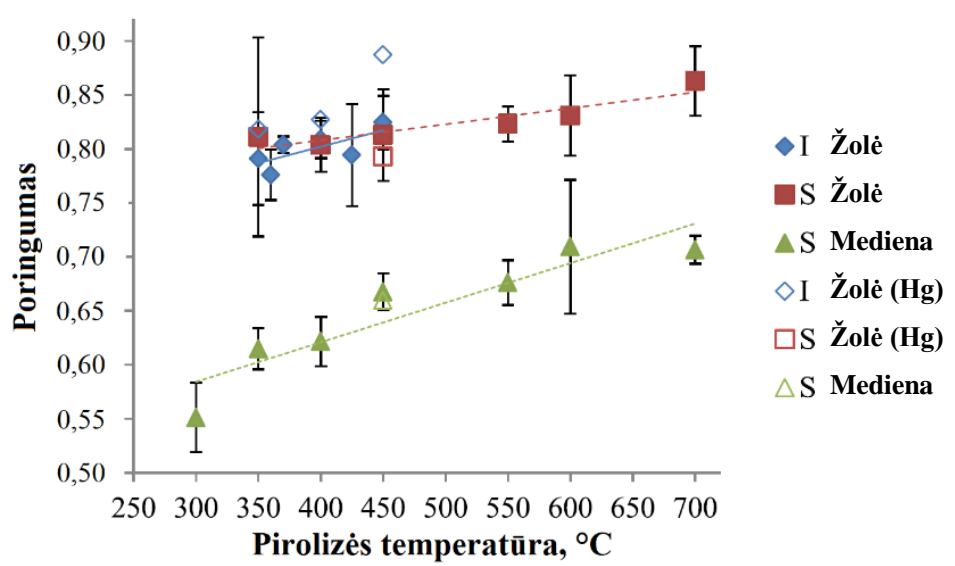

1.8 pav. Bioanglies poringumo priklausomybè nuo pirolizès temperatūros (Brewer et al., 2014)

Fig. 1.8. Dependence of biochar porosity on pyrolysis temperature (Brewer et al., 2014)

Bioanglies tankis priklauso nuo pradinès žaliavos bei pirolizès sąlygų ir yra labai ịvairus. Karim et al. (2020) nustaté, kad akacijos medienos bioanglies $\left(550{ }^{\circ} \mathrm{C}, 3,5\right.$ val.) piltinis tankis sieke $0,11 \mathrm{~g} / \mathrm{cm}^{3}$. Atlikus kitą tyrimą (Werdin et al., 2020) buvo padaryta išvada, kad bioanglis, pagaminta iš mažesnio tankio eukalipto medžio rūšių, pasižymėjo didesne vandens laikomaja geba ir augalams prieinamu vandens kiekiu nei didesnio tankio žaliavos. Bioanglis $\left(550^{\circ} \mathrm{C}, 4\right.$ val.), pagaminta iš spindulinio eukalipto (Eucalyptus radiata), pasižymèjo didžiausiu augalams prieinamu vandens kiekiu (42,2\%), kai minèta mediena pasižymèjo palyginti mažu tankiu $\left(689 \mathrm{~kg} / \mathrm{m}^{3}\right)$. O bioanglis, pagaminta iš didžiausio tankio $\left(960 \mathrm{~kg} / \mathrm{m}^{3}\right)$ medienos (E. polybractea), pasižymèjo mažiausiu augalams prieinamu vandens kiekiu (28,6 \%). Panašiai bioanglis, pagaminta iš mažesnio tankio eukalipto medienos, pasižymèjo iki $35 \%$ didesne vandens laikomaja geba, lyginant su didesnio tankio mediena. Medienos tankis stipriai siejosi su žaliavos ląstelių struktūra. Buvo pasiūlyta, kad mažesnio tankio mediena su didesniais skaidulų skersmenimis ir plonesnèmis sienelèmis yra tinkamesnès bioanglies, pasižyminčios didesne augalams prieinamo vandens porų proporcija, gamybai.

Taigi atlikti tyrimai rodo, kad lignoceliuliozinè medienos biomasė yra tinkama gaminti poringają bioangli dèl jos mažo pelenų kiekio, didelio lignino kiekio ir originalios biomasès porų struktūros išlaikymo. Bioanglies poringumas, išreikštas porų skersmeniu, mikroporų, mezoporų ir makroporų tūriu bei paviršiaus plotu, turi didelę svarbą sorbcijos procesams. Lignoceliuliozinès biomasès morfologinė struktūra yra palanki mikroporingumo vystymuisi, lyginant su kitomis žaliavomis. 


\subsubsection{Cheminès savybès}

Daugelis cheminiu reakcijų tarp bioanglies ir aplinkos tiesiogiai siejasi su paviršiaus cheminėmis savybėmis (Brewer, 2012). Medžiagos paviršiaus funkcinès grupès atlieka svarbų vaidmenị ịvertinant sorbentų adsorbcinę gebą dviem būdais. Pirma, funkcinès grupès sukelia tikrajj paviršiaus rūgštingumą / baziškumą. Jos yra hidrofiliškos arba hidrofobiškos ir gali veikti kaip adsorbcinès vietos vandeniui. Antra, funkcinės grupès yra protonacijos $\left(\mathrm{H}^{+}\right.$jono prisijungimo) ir deprotonacijos $\left(\mathrm{H}^{+}\right.$jono praradimo) veiksnys, dèl ko atsiranda krūvis ant viso paviršiaus ir susiformuoja dvigubas elektrinis laukas šalia paviršiaus esančiame tirpale. Hidrofobinès ir hidrofilinès bioanglies paviršiaus sritys gali veikti kaip aplinkos nepolinių ir polinių organinių molekulių adsorbentai. Ši adsorbcinė geba gali teikti naudą, kai bioanglis adsorbuoja organinę medžiagą arba aplinkos teršalus.

Kiekviena bioanglies dalelè yra sudaryta iš dviejų dalių: kristalinių grafeno lakštų ir atsitiktinai išsidèsčiusių amorfinių aromatinių struktūrų. Kristalines bioanglies dalis sudaro konjuguoti aromatiniai junginiai (Gezahegn et al., 2019). Bioanglies matriksą taip pat sudaro aromatiniai-alifatiniai junginiai, lakieji junginiai ir neorganiniai pelenai su įvairiomis tuštumomis ir poromis. Šiuose aromatiniuose žieduose yra inkorporuoti H, O, N, P ir S atomai (Brewer 2012). Bioanglies paviršiaus cheminè sudètis yra kompleksiška ir heterogeniška, todèl ji gali sąveikauti su daugybe aplinkos organinių ir neorganinių junginių. Šių sąveikų produktai yra funkcinès grupès. Lignoceliuliozinèse žaliavose paviršiaus funkcines grupes daugiausia sudaro hidroksilinès $(-\mathrm{OH})$, karboksilinès rūgštys $(-\mathrm{COOH})$ ir mažos alkilinès grandinès, pvz., metilo grupès $\left(-\mathrm{CH}_{3}\right)$. Tipinès bioanglies funkcinès grupés pavaizduotos 1.9 paveiksle.

Rūgštinès grupès

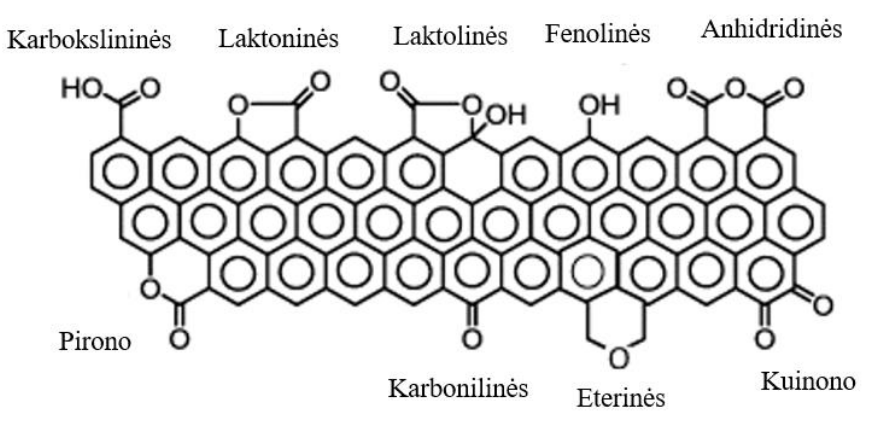

Neutralios arba bazinès grupès

1.9 pav. Tipinės deguonị turinčios funkcinès grupès ant bioanglies paviršiaus (Li et al., 2011)

Fig. 1.9. Typical oxygen-containing functional groups on the biochar surface (Li et al., 2011) 
Remiantis Zhao et al., (2019) tyrimu, juodosios tuopos bioanglis $\left(500-550{ }^{\circ} \mathrm{C}\right)$ pasižymejjo FTIR pikais ties $1698 \mathrm{~cm}^{-1}$ (karboksilinè grupè), $1672 \mathrm{~cm}^{-1}$ (ketoninès ir esterinès grupès), $1236 \mathrm{~cm}^{-1}(\mathrm{C}=\mathrm{O} / \mathrm{C}-\mathrm{O}-\mathrm{O}$ grupès $)$ ir $1029 \mathrm{~cm}^{-1}(\mathrm{C}-\mathrm{N}$ grupè $)$. Kukurūzų bioanglis $\left(400-500^{\circ} \mathrm{C}\right)$ pasižymèjo dviem pikais ties $1723 \mathrm{~cm}^{-1}$ (karboksilinè grupè) ir $1644 \mathrm{~cm}^{-1}$ (ketoninès ir esterinès grupès). Karboksilinè rūgštinè grupè yra labai naudinga sunkiujų metalų adsorbcijai ir gali būti randama daugelyje lignoceliuliozinè kilmės adsorbentų. Zhao et al. (2017) nustatè, kad kai pirolizès temperatūra didèjo nuo $300 \mathrm{iki} 600^{\circ} \mathrm{C}$, bendras rūgštinių funkcinių grupių skaičius, paviršiaus karboksilinių, fenolinių ir laktoninių funkcinių grupių skaičius mažejo atitinkamai nuo 1,16 iki $0,44 \mathrm{mmol} / \mathrm{g}$, nuo $0,49 \mathrm{iki} 0,23 \mathrm{mmol} / \mathrm{g}$, nuo 0,33 iki $0,09 \mathrm{mmol} / \mathrm{g}$ ir nuo $0,34 \mathrm{iki} 0,13 \mathrm{mmol} / \mathrm{g}$. Pirolizès proceso metu organinè medžiaga verčiama ị vandenị ir dujas, todèl aukštesnè temperatūra lemia didesnị lakiưjų junginių susidarymą, dèl ko bendras rūgštinių grupių kiekis mažèja. 1.3 lentelèje parodytos funkcinès grupés, kurios aptinkamos bioanglyje FTIR technika.

1.3 lentelè. Funkcinès grupès, aptiktos Furjè transformacijos infraraudonujų spindulių spektru bioanglyje (Zhao et al., 2017)

Table 1.3. Functional groups detected by Fourier-transform infrared spectrum in biochar (Zhao et al., 2017)

\begin{tabular}{|l|l|}
\hline \multicolumn{1}{|c|}{ Bangos skaičius $\left(\mathrm{cm}^{-1}\right)$} & \multicolumn{1}{c|}{ Funkcinè grupe் } \\
\hline $3500-3200$ & $\mathrm{O}-\mathrm{H}$ \\
\hline 2935 & $\mathrm{C}-\mathrm{H}$ \\
\hline 1600 & Aromatinè $\mathrm{C}=\mathrm{C}$, ketonų ir kuinonų $\mathrm{C}=\mathrm{O}$ \\
\hline 1440 & Lignino angliavandenilių $\mathrm{C}=\mathrm{C}$ \\
\hline 1325 & Fenolių $\mathrm{O}-\mathrm{H}$ \\
\hline $1100-1030$ & Celiuliozès, hemiceliuliozės ir lignino $\mathrm{C}-\mathrm{O}$ \\
\hline 885 & Aromatinė $\mathrm{C}-\mathrm{H}$ \\
\hline
\end{tabular}

Bioanglies struktūra paprastai priklauso nuo anglies atomų išsidèstymo pirogeniniuose junginiuose, susiformuojančiuose terminio skaidymo metu. Supratimas apie dominuojančias anglies (C) atomų formas bioanglyje yra svarbus veiksnys nustatant bioanglies chemines savybes ir reaktyvumą. Dominuojančias $\mathrm{C}$ formas sudaro alifatinès, aromatinès, karboksilinès ir karbonilinès struktūrinès grupès. 1.4 lentelè rodo, kad bendras anglies atomų kiekis, nustatytas Bruker DSX300 13C BMR spektrometru, yra pasiskirstęs tarp skirtingų struktūrinių grupių priklausomai nuo pasirinktos medžiagos ir pirolizès temperatūros (Herath et al., 2012). 
1.4 lentelè. Procentinis bendro $\mathrm{C}$ kiekio pasiskirstymas tarp bioanglies, pagamintos iš skirtingų žaliavų ir temperatūrų, funkcinių grupių, ND - nèra duomenų (Herath 2012)

Table 1.4. Percentage distribution of total $\mathrm{C}$ between biochar produced from different feedstocks and at different temperatures, functional groups, ND - no data available (Herath 2012)

\begin{tabular}{|c|c|c|c|c|c|}
\hline Žaliava & $\begin{array}{c}\text { Pirolizès } \\
\text { temperatūra } \\
\left({ }^{\circ} \mathrm{C}\right)\end{array}$ & Alifatinès & $\begin{array}{l}\text { Aromati- } \\
\text { nès }\end{array}$ & $\begin{array}{l}\text { Karboksili- } \\
\text { nès }\end{array}$ & $\begin{array}{l}\text { Karboni- } \\
\text { linès }\end{array}$ \\
\hline \multirow{2}{*}{$\begin{array}{l}\text { Žemès riešutų } \\
\text { kevalai }\end{array}$} & 400 & 35 & 57 & 5 & 3 \\
\hline & 500 & 12 & 82 & 3 & 3 \\
\hline \multirow{2}{*}{$\begin{array}{l}\text { Pekano riešutų } \\
\text { kevalai }\end{array}$} & 350 & 49 & 42 & 4 & 5 \\
\hline & 700 & 29 & 58 & 14 & 0 \\
\hline \multirow{2}{*}{$\begin{array}{l}\text { Viščiukų } \\
\text { ekskrementai }\end{array}$} & 350 & 36 & 57 & 4 & 3 \\
\hline & 700 & ND & ND & ND & ND \\
\hline \multirow[t]{2}{*}{ Soros augalas } & 250 & 63 & 29 & 5 & 3 \\
\hline & 500 & 12 & 82 & 3 & 3 \\
\hline
\end{tabular}

Be anglies ir vandenilio $(\mathrm{H})$, bioanglis susideda daugiausia iš deguonies $(\mathrm{O})$, azoto $(\mathrm{N})$ ir sieros $(\mathrm{S})$ atomų. Šių elementų randama aromatinių žiedų funkcinèse grupèse ir turi poveikị specifinėms bioanglies cheminèms savybėms. Galutinès pirogeninès medžiagos elementinè sudètis labiausiai priklauso nuo žaliavos tipo ir pirolizès temperatūros. Kitaip tariant, šie veiksniai daugiausia nusako bioanglies kiekybę bei savybes. 1.5 lentelëje pateikiama informacija apie bioanglies tipu elementinę analizę po žaliavos pirolizès (Herath et al., 2012).

1.5 lentelė. Bioanglies elementinè sudètis, SM - sausoji masè (Herath et al., 2012)

Table 1.5. Elemental composition of biochar, SM - dry mass (Herath et al., 2012)

\begin{tabular}{|l|l|l|l|l|l|l|}
\hline \multicolumn{1}{|c|}{ Žaliava } & $\begin{array}{c}\mathrm{C} \\
(\mathrm{SM} \%)\end{array}$ & $\begin{array}{c}\mathrm{H} \\
(\mathrm{SM} \%)\end{array}$ & $\begin{array}{c}\mathrm{O} \\
(\mathrm{SM} \%)\end{array}$ & $\begin{array}{c}\mathrm{N} \\
(\mathrm{SM} \%)\end{array}$ & $\begin{array}{c}\mathrm{S} \\
(\mathrm{SM} \%)\end{array}$ & $\begin{array}{l}\text { Pelenai } \\
(\mathrm{SM} \%)\end{array}$ \\
\hline Kukurūzų burbuolès & 86,4 & 1,2 & 5,34 & 0,56 & 0,05 & 4,31 \\
\hline $\begin{array}{l}\text { Mimosoidinio medžio } \\
\text { (Laucaena) mediena }\end{array}$ & 85,4 & 1,27 & 6,37 & 0,53 & 0,04 & 4,62 \\
\hline Ažzuolo lentelès & 91,5 & 1,22 & 3,55 & 0,18 & 0,01 & 1,04 \\
\hline Pušies mediena & 94,6 & 1,06 & 3,09 & 0,11 & 0,04 & 0,69 \\
\hline Ryžiu lukštai & 52,6 & 0,82 & 3,87 & 0,57 & 0,06 & 41,3 \\
\hline
\end{tabular}


Pagrindinis bioanglies gamybos tikslas - pakeisti biomasės cheminę sudètį, o daugiausia - didinti $\mathrm{C}$ kiekį. Tai vyksta dèl funkcinių grupių, turinčių $\mathrm{O}$ ir $\mathrm{H}$, atskyrimo, todèl, didèjant gamybos temperatūrai, $\mathrm{C}$ kiekis taip pat didejja, o $\mathrm{H}$ ir O kiekiai mažèja. $\mathrm{C}$ ir O kiekio kitimas medienos bioanglyje pasižymi veidrodiniu atspindžiu (1.10 pav.). C kiekis nepaveiktoje medienoje paprastai siekia per $50 \%$, o kiekis - daugiau nei $40 \%$. Aukštos temperatūros bioanglies tipai gali pasiekti C kiekius, viršijančius $95 \%$, O kiekius, mažesnius nei $5 \%$. H kiekis medienoje varijuoja nuo 5 iki $7 \%$ ir mažejja iki $2 \%$, didejant temperatūrai $\left(>700^{\circ} \mathrm{C}\right)$. C, O ir $\mathrm{H}$ kiekiai medienos bioanglies tipuose kinta panašiai kylant temperatūrai, nepaisant ịvairių medžių rūšių skirtumų ir apdorojimo sąlygų. Nèra aiškios koreliacijos tarp temperatūros ir N kiekio (Weber, Quicker, 2018).

a)

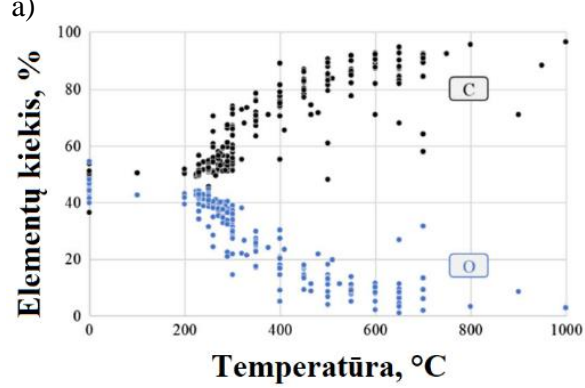

b)

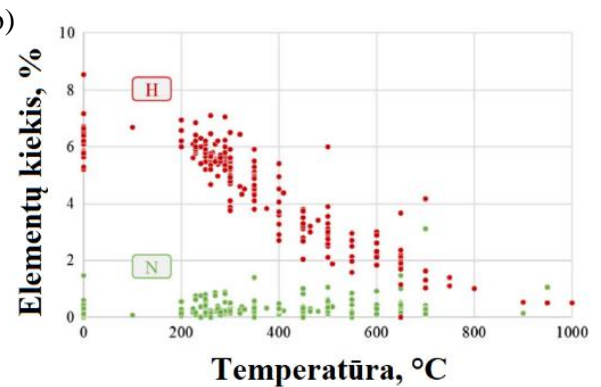

1.10 pav. Medienos bioanglies elementų kiekio (\%) priklausomybè nuo pirolizès temperatūros: a) anglies ir deguonies; b) azoto ir vandenilio (Weber, Quicker, 2018) Fig. 1.10. Content of elements (\%) in wood biochar according to pyrolysis temperature: a) carbon and oxygen; b) nitrogen and hydrogen (Weber, Quicker, 2018)

Dažnai naudojami atominiai $\mathrm{O} / \mathrm{C}$ ir $\mathrm{H} / \mathrm{C}$ santykiai bioanglies cheminei sudèčiai charakterizuoti. Jie svarbūs tuo, kad gali teikti žinių apie bioanglies ryšị su jos poliškumu, todèl ir apie jos sąveiką su vandeniu. H/C santykis gali būti naudojamas vidutiniam $\mathrm{C}-\mathrm{H}$ jungčių ịvertinimui anglies atome (Vantieghem, 2016). Dažnai brěžiama Van Kreveleno diagrama, kuri rodo, kaip kinta bioanglies funkcionalumas priklausomai nuo laiko, siejant ji su $\mathrm{H} / \mathrm{C}$ ir $\mathrm{O} / \mathrm{C}$ atominiais santykiais. Remiantis minèta diagrama, dominuojančios reakcijos, vykstančios pirolizès metu, yra dehidratacijos, dekarboksilizacijos ir demetilizacijos. 1.11 paveiksle Van Krevelenon diagrama pavaizduota remiantis Jafri et al. (2018) darbu. Jame palyginti skirtingų žaliavų bioanglies atominiai santykiai. Nguyen ir Lehmann (2009) nustate didesnị tiek javų, tiek ąžuolo bioanglies, pagamintos esant $600{ }^{\circ} \mathrm{C}$ temperatūrai, lyginant su $350^{\circ} \mathrm{C}$, aromatingumą bei mažesnius $\mathrm{H} / \mathrm{C}$ ir $\mathrm{O} / \mathrm{C}$ santykius. 


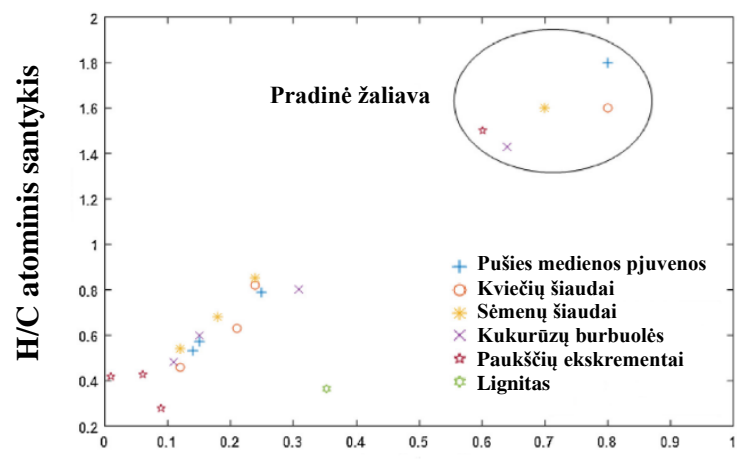

$\mathrm{O} / \mathrm{C}$ atominis santykis

1.11 pav. Van Kreveleno diagrama, vaizduojanti skirtingų bioanglies tipų elementinès sudèties pokyčius priklausomai nuo atominių santykių (Jafri et al., 2018)

Fig. 1.11. Van Krevelen diagram depicting changes in the elemental composition of different biochar types according to atomic ratios (Jafri et al., 2018)

Taigi bioanglies cheminė struktūra ir elementinè sudètis labiausiai priklauso nuo žaliavos tipo ir pirolizès temperatūros. Deguonis siejasi su biomasès žaliavos funkcinėmis grupèmis (hidroksilinėmis, fenolinėmis, eterio, karbonilinėmis ir karboksilinėmis). $\mathrm{H}$ siejasi su alifatiniais junginiais ir paviršiaus aromatinėmis struktūromis (aromatine $\mathrm{C}-\mathrm{H}$ ). Pirolizès metu $\mathrm{H}$ ir $\mathrm{O}$ yra prarandami kaip $\mathrm{H}_{2} \mathrm{O}$, o $\mathrm{C}$ kondensuojasi $\mathrm{i}$ aromatines struktūras. Sisteminius bioanglies elementinès sudèties pokyčius taip pat atspindi atvirkštinis sąryšis tarp $\mathrm{H} / \mathrm{C}$ bei $\mathrm{O} / \mathrm{C}$ atominių santykių bei pirolizès temperatūra.

\subsection{Bioanglies drẻkumo nustatymo metodai}

Kontakto laipsnis yra tipinis bioanglies drékumo nustatymo parametras: kuo mažesnis bioanglies drékumas, tuo didesnis kontakto laipsnis, ir atvirkščiai (Das, Sarmah, 2015). Jis parodo kietosios ir skystosios medžiagos sąveikos drékumo laipsnị. Mažas kontakto laipsnis $\left(<90^{\circ}\right)$ rodo didelị drékumą, o didelis $\left(>90^{\circ}\right)$ mažą drèkumą (Yuan, Lee, 2013).

Daugelis technikų, naudojamų kontakto laipsniui ịvertinti, klasifikuojama ị dvi pagrindines grupes: tiesiogini optinị metodą ir netiesiogini jègų metodą (Yuan, Lee, 2013). Plačiausiai naudojama technika kontakto laipsniui ịvertinti yra tiesioginis tangento laipsnio nustatymas trijų fazių kontakto taške, esančiame nejudriame lašelio profilyje. Kai vandens lašelis užlašinamas ant paviršiaus, jis gali igauti formas, pavaizduotas 1.12 paveiksle. Kontakto laipsni veikia šie veiksniai: cheminès kietosios medžiagos paviršiaus kilmè, paviršiaus poringumo bei kitos 
molekulès, esančios ant paviršiaus. Bet kuris iš šių arba visi veiksniai gali sumažinti kontakto laipsni medžiagai sudrèkstant.
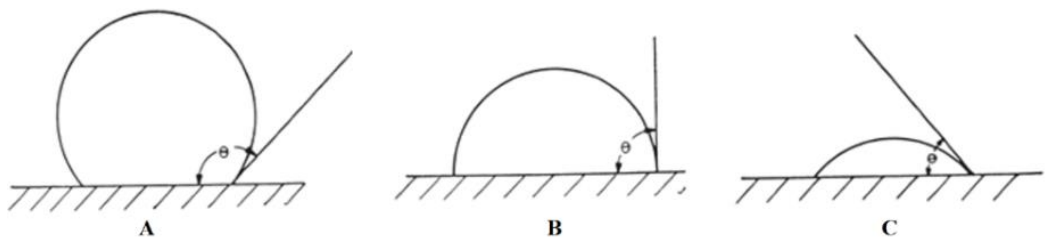

1.12 pav. Lašelių formos ant kietuju paviršių: $\mathrm{A}$ - kontakto laipsnis tarp $90^{\circ}$ ir $180^{\circ}-$ nedrèkus paviršius; $\mathrm{B}-90^{\circ}$ - vidutinio drèkumo; $\mathrm{C}-\operatorname{tarp} 0^{\circ}$ ir $90^{\circ}$ - drèkus (Rowen, Gagliardi, 1947)

Fig. 1.12. Droplet shapes on solid surfaces: $\mathrm{A}$ - contact angle between $90^{\circ}$ and $180^{\circ}$ non-wettable surface; $\mathrm{B}-90^{\circ}$ - medium wettability; $\mathrm{C}$ - between $0^{\circ}$ and $90^{\circ}-$ wet)

(Rowen, Gagliardi, 1947)

Bigelow 1946 m. sukūrè paprastą instrumentą, kurị pavadino teleskopiniu goniometru, skirtu ịvairių skysčiu ant nupoliruotu paviršių kontakto laipsniui ịvertinti. Šis tiesioginis optinis metodas turi pranašumų dẻ jo paprastumo ir fakto, kad reikalingi nedideli skysčio (keli $\mu$ l) ir maži paviršiaus substrato (keli $\mathrm{mm}^{2}$ ) kiekiai. Pirmasis komercinis kontakto laipsnio goniometras, projektuotas W. A. Zismano, buvo pagamintas $1960 \mathrm{~m}$. rema-hart instrumentų kompanijos (1.13 pav.). Šiuo metu visi goniometrų tiekejjai teikia susietą kompiuterių programinę įrangą, kuri leidžia interpretuoti rezultatus (Williams et al., 2010). Trys atvirosios prieigos programos yra ImageJ programos papildiniai.

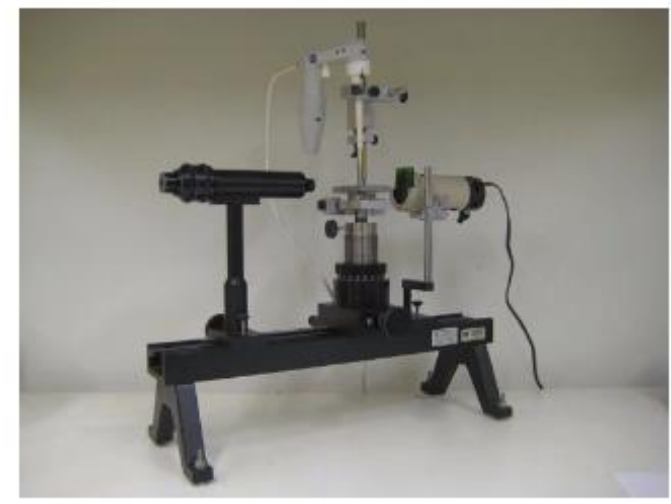

1.13 pav. Teleskopinis goniometras, skirtas kontakto laipsniui matuoti (Yuan, Lee, 2013)

Fig. 1.13. Telescopic goniometer for measuring the contact angle (Yuan, Lee, 2013) 
Vandens lašelio skverbimosi laikas (VLSL) yra naudingas metodas, taikomas tiriamų medžiagų drèkumui vertinti. Jị sudaro vandens lašelio nuleidimas ant tiriamos medžiagos paviršiaus ir laiko, skirto visiškam prasiskverbimui, įvertinimas. Jei lašelis iš karto neprasiskverbia, medžiaga laikoma kaip hidrofobinė (Stevenson, 2016). Atliekant šị testą, naudojantis laikmačiu, vertinama, kiek laiko užtruks vandeniui prasiskverbti pro mėginį (Kinney et al., 2012). Trumpiausias laikas $(0,2 \mathrm{~s})$ atitinka momentinị prasiskverbimą. İvertinimai baigiami praejjus $3600 \mathrm{~s}$ ( 1.6 lentelèje).

1.6 lentelè. Medžiagos drèkumo kategorijos su atitinkamais vandens lašelių skverbimosi laikais (Leelamanie et al., 2008)

Table 1.6. Wettability categories of the material with appropriate water droplet penetration times (Leelamanie et al., 2008)

\begin{tabular}{|l|l|}
\hline \multicolumn{1}{|c|}{ VLSL, $\mathrm{s}$} & \multicolumn{1}{c|}{ Drëkumo kategorija } \\
\hline$\leq 1 \mathrm{~s}$ & Hidrofiliškas \\
\hline $1-60 \mathrm{~s}$ & Nežymiai hidrofobiškas \\
\hline $60-600 \mathrm{~s}$ & Stipriai hidrofobiškas \\
\hline $600-3600 \mathrm{~s}$ & Labai hidrofobiškas \\
\hline$\geq 3600 \mathrm{~s}$ & Ypatingai hidrofobiškas \\
\hline
\end{tabular}

Stevenson (2016) vertino vynmedžio bioanglies drẻkumą priklausomai nuo vėsinimo, įmirkimo ir prisotinimo vandeniu remdamasis VLSL testu. Arbatiniu šaukšteliu buvo paimta maža bioanglies dalis (1.14 pav.). Buvo naudojamas $1 \mathrm{~mm}$ švirkštas, kuriuo vandens lašelis buvo paleistas iš $<10 \mathrm{~mm}$ aukščio. Skverbimosi laikas buvo pradètas skaičiuoti nuo pirmojo vandens ir bioanglies kontakto momento ir baigtas skaičiuoti, kai lašelis visiškai prasiskverbė pro medžiagą.

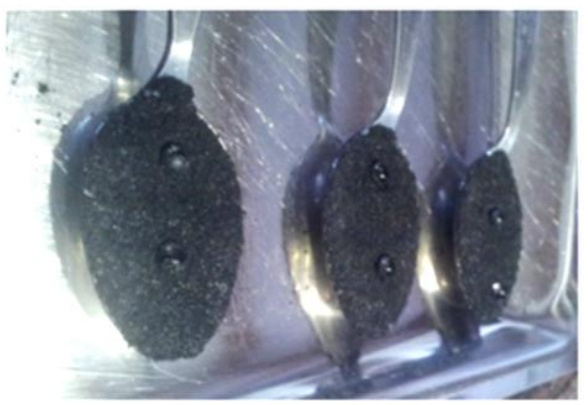

1.14 pav. VLSL testas su bioanglimi (Stevenson 2016)

Fig. 1.14. WDPT test with biochar (Stevenson 2016) 
Etanolio lašelio molingumo (ELM) testas buvo išrastas Doerr 1998 m. ir vèliau modifikuotas kitų tyrèjų, naudojusių įvairias medžiagas. Šiame tyrime naudojami septyni etanolio ir dejonizuoto vandens mišiniai jų sorbcijai pro bioanglies paviršių vertinti. Testuoti naudojamos etanolio tirpalo koncentracijos: 0, 3, 5, 11, 13, 18, 24 ir $36 \%$ (1.7 lentelè). $0 \%$ etanolio verte atitinka labai hidrofilišką medžiagą, o $36 \%$ vertè - ypatingai hidrofobišką. Lašeliai lašinami ant medžiagos paviršiaus iš ne didesnio nei $5 \mathrm{~mm}$ aukščio (Page-Dumroese et al., 2015). Jei tirpalas prasisunkia pro bioangli per $3 \mathrm{~s}$, medžiagai priskiriamas atitinkamas drèkumo indeksas (Bontchev et al., 2016).

1.7 lentelè. Bioanglies drèkumo indeksai su atitinkamomis etanolio tirpalų koncentracijomis (Bontchev et al., 2016)

Table 1.7. Wettability indices of the biochar with appropriate concentrations of ethanol solutions (Bontchev et al., 2016)

\begin{tabular}{|l|l|}
\hline Etanolio koncentracija tirpale, $\%$ & \multicolumn{1}{c|}{ Drèkumo indeksas } \\
\hline 0 & 0 labai hidrofiliškas \\
\hline 3 & 1 hidrofiliškas \\
\hline 5 & 2 nežymiai hidrofiliškas \\
\hline 11 & 3 nežymiai hidrofobiškas \\
\hline 13 & 4 vidutiniškai hidrofobiškas \\
\hline 18 & 5 stipriai hidrofobiškas \\
\hline 24 & 6 labai hidrofobiškas \\
\hline 36 & 7 ypatingai hidrofobiškas \\
\hline
\end{tabular}

Hale et al. (2015) tyrime bioanglies drékumas buvo vertinamas sausuose mèginiuose, persijotuose per $0,5 \mathrm{~mm}$ sietą pagal ELM testą. Žematemperatūrès $\left(300{ }^{\circ} \mathrm{C}\right)$ pušies bioanglies drékumo indeksas siekė 1 (hidrofiliška medžiaga), o aukštatemperatūrès $\left(600^{\circ} \mathrm{C}\right)$ pušies bioanglies - 4, kuris rode vidutinišką medžiagos hidrofobiškumą. Atliekant kitą tyrimą (Kinney et al., 2012) bioanglies, pagamintos iš magnolijos lapų, obels pjuvenų ir paprastojo kukurūzo pašaro meginiu paviršiaus drèkumas taip pat buvo vertinamas naudojantis ELM testu. Korenkova et al. (2015) tyrime, priklausomai nuo etanolio lašelio molingumo (M, mol/l), dirvožemių drèkumas buvo klasifikuojamas taip: 0-0,85 - M drèkus, $0,85-1,45 \mathrm{M}$ - nežymiai hidrofobiškas, $1,45-2,22 \mathrm{M}$ - vidutiniškai hidrofobiškas, 2,22-3,07 M - stipriai hidrofobiškas, 3,07-6,14 M - labai stipriai hidrofobiškas ir $>6,14 \mathrm{M}$ - ypatingai hidrofobiškas. 
Kitas iš bioanglies drèkumo ịvertinimo būdų - branduolių magnetinis rezonansas (BMR). Jis siejasi su atomų branduolių atsaku į magnetinius laukus. Daugelis branduolių turi magnetinị impulsą ir veikia kaip besisukantys magnetai. Šie besisukantys magnetiniai branduoliai gali sąveikauti su išorejje sukurtais magnetiniais laukais ir sukurti išmatuojamą signalą (Branco, Gil, 2017). Daugeliui elementų aptinkami signalai yra labai maži. Kita vertus, $H$ turi palyginti dideli magnetinị impulsą ir jo yra gausu vandenyje ir angliavandeniliuose. BMR metodas paprastai susideda iš $\mathrm{H}$ protonų veikimo medžiagos porų vandens molekulèse.

Conte ir Nestle (2015) tyré bioanglies dalelių dydžio poveiki vandens dinamikai, kad būtų galima gauti informacijos apie maistinių medžiagų mobilumą i augalo šaknis, kai dirvožemis pagerinamas bioanglimi. Tuopos bioanglis nerūdijančiuoju plieniniu ịrankiu buvo susmulkinta ị tris skirtingas frakcijas $(1,0$ $2,0 \mathrm{~mm}, 0,3-1,0 \mathrm{~mm}$ ir $<0,3 \mathrm{~mm})$. Vandenyje prisotintos frakcijos buvo analizuotos naudojantis greitojo lauko ciklo BMR relaksometrija. Rezultatai patvirtino, kad 3D mainai tarp surištojo ir piltinio vandens daugiausia vyko stambiausioje frakcijoje. Kita vertus, kai poringumas mažèjo, vandens judèjimas daugiausia siejosi su ribota $2 \mathrm{D}$ difuzija tarp paviršiaus porų ir piltinio vandens. Kitame tyrime (Bubici et al., 2016) buvo vertinama vandens trauka ant bioanglies paviršiaus naudojantis BMR technika su nauju matematiniu modeliu bei duomenu interpretacija. Tiek BMR, tiek kontakto laipsnio rezultatai parodė panašią tirtų bioanglies tipų drẻkumo tendenciją. BMR relaksometrijos pranašumas prieš kontakto laipsnio ịvertinimą yra tai, kad galima gauti daug skirtingos informacijos mikroskopiniu lygmeniu. Kai kontakto laipsnis teikia tik drékumo įvertinimą, BMR relaksometrija leidžia suprasti vandens molekulinès dinamikos ant bioanglies paviršiaus mechanizmus.

\subsection{Biologiniai, fizikiniai ir cheminiai bioanglies modifikacijos būdai}

Bioanglies modifikacija apibrèžiama kaip apdorojimo technologijų pritaikymas gerinti bioanglies sorbcines savybes (Inyang et al., 2013). Bioanglies sorbcinè geba itin priklauso nuo jos paviršiaus charakteristikų (paviršiaus ploto, krūvio, elementinès sudeties ir funkcinių grupių), kurios savo ruožtu yra veikiamos žaliavos tipo ir produkcijos sąlygų (Lou et al., 2016). Inžineriniai metodai, gerinantys bioanglies savybes, skirstomi i fizikinius, cheminius ir biologinius. Fizikinè modifikacija atliekama dèl bioanglies paviršiaus ploto ir porų tūrio didinimo, apima tokius mechaninius apdorojimo procesus, kaip pradinès biomasès arba bioanglies smulkinimas. Hallin et al. (2015) nustatè, kad smulki bioanglis (dalelių dydis $<250 \mu \mathrm{m}$ ) buvo reikšmingai efektyvesnè didinant hidrofobinių stambios bei vidutinès tekstūros dirvožemių drėkumą nei stambi bioanglis (250- 
$2000 \mu \mathrm{m})$. Cheminę modifikaciją sudaro šarmų $(\mathrm{KOH}, \mathrm{NaOH})$, rūgščių $\left(\mathrm{H}_{3} \mathrm{PO}_{4}\right.$, $\mathrm{H}_{2} \mathrm{O}_{2}$ ) ir organinių medžiagų (vandeninių gelių, aerogelių) ịterpimas, o pastaruoju metu ir metalų oksidų bei nanodalelių naudojimas aktyvintosios anglies, turinčios geresnių paviršiaus cheminių savybių, gamybai. Neseniai buvo pasiūlyta biologinė modifikacija kaip vienas iš bioanglies modifikacijos metodų jos sorbcinèms savybėms didinti. Modifikacijos metodų pasirinkimas priklauso nuo sorbuojamų teršalų tipo (neorganiniai ar organiniai, anijoniniai ar katijoniniai, hidrofiliniai ar hidrofobiniai, poliniai ar nepoliniai), aplinkos sąlygų ir aplinkos atstatymo tikslų (Rajapaksha et al., 2016).

Šiuo metu ieškoma būdų, kaip būtų galima pagerinti žematemperatūrès bioanglies trauką vandeniui atkartojant aukštatemperatūrę bioanglị ir taip mažinant energetiškai intensyvios pirolizès poreikị. Das ir Sarmah (2015) straipsnyje siūloma bioangli paveikti lietaus ar paviršiaus nuotèkio vandeniu, kuris galètų potencialiai pakeisti jų savybes. Taip pat siūloma taikyti techniką, iki šiol naudojamą pakeisti naftą uolienose, taip mažinant bioanglies hidrofobiškumą. Naudojant tokią bioangli žemès ūkyje gali padidèti drègmès kontrolè, maisto medžiagų sulaikymas ir efektyvumas, derlius, sumažèti suvartojamo vandens ir maisto medžiagų kiekis, paviršiaus nuotekis ar išsiplovimas (Bontchev et al., 2016).

Das ir Sarmah (2015) straipsnyje siūloma bioangli paveikti lietaus ar paviršiaus nuotėkio vandeniu, kas galètų potencialiai pakeisti jos savybes dèl drèkumo didinimo. Dèl to būtina žinoti, kokių savybių turi vietinis lietaus vanduo, kuris galètu paveikti bioanglies savybes. Remiantis atmosferos kritulių tyrimais, lietaus vanduo $2017 \mathrm{~m}$. Aukštaitijos integruoto monitoringo (IM) stotyje turèjo šiu cheminių savybių: didelèmis sulfatų $27 \mathrm{mgS} / \mathrm{m}^{2}$ (rugsèjo mèn.), nitratų $28,9 \mathrm{gN} / \mathrm{m}^{2}$ ir amonio 95,5 mgN/m $\mathrm{m}^{2}$ (kovo mèn.) koncentracijomis (Ataskaita, 2016). $\mathrm{SO}_{2}$ vertès siekè nuo 0,09 iki $0,67 \mu \mathrm{gS} / \mathrm{m}^{3} ; \mathrm{NO}_{2}$ - nuo $0,15 \mathrm{iki} 1,30 \mu \mathrm{gN} / \mathrm{m}^{3}$; sulfatų nuo $0,10 \mathrm{iki} 1,20 \mu \mathrm{gS} / \mathrm{m}^{3}$; suminio $\mathrm{NO}_{3}$ - nuo $0,08 \mathrm{iki} 0,79 \mu \mathrm{gN} / \mathrm{m}^{3}$; suminio $\mathrm{NH}_{4}-$ nuo 0,06 iki $1,60 \mu \mathrm{gN} / \mathrm{m}^{3}$. Didžiausios $\mathrm{SO}_{2}$ ir $\mathrm{NO}_{2}$ koncentracijos visose tyrimo vietose nustatytos šaltuoju metų laiku. Aukštaitijos IM stotyje kritulių $\mathrm{pH}$ vertès savaitès mėginiuose kito nuo 4,10 iki 6,52. Rūgštūs krituliai, kurių $\mathrm{pH}$ vertès buvo mažesnès nei 5,0, vyravo sausio-vasario, rugpjūčio-rugsėjo, lapkričio mėnesiais. Kitais mėnesiais kritulių pH kito intervale 5,0-6,52.

Dervos, pelenai ar lakieji organiniai junginiai gali būti pašalinami nuo bioanglies paviršiaus ar porų naudojantis vakuumu, junginiais, mažinančiais skysčio paviršiaus ịtemptị (paviršiaus aktyvūs agentai, kaip kad ramnolipidinė medžiaga (1.15 pav.)), ultragarsu, cheminiu poveikiu ar kitais būdais, kurie šalina arba pakeičia nenaudingus junginius, dèl to galutinè bioanglis gali išlaikyti daugiau vandens bei maistinių medžiagų (Bontchev et al., 2016). Pagrindines biologiškai aktyvių agentų klases sudaro glikolipidai, fosfolipidai, polimeriniai biologiškai aktyvūs agentai ir lipopeptidai (surfaktinai). Geriausiai žinomi glikolipidai yra 
ramnolipidai, soforolipidai ir trehalolipidai. Lyginant su kitais glikolipidiniais agentais, ramnolipidai pritaikomi plačiau - nuo aplinkos atstatymo iki naudojimo pramonèje. Šiuo metu ramnolipidai taikomi organiniams junginiams užterštuose dirvožemiuose skaidyti ( $\mathrm{Vu}$ et al., 2015). Be biologinio skaidymo, jie taip pat skatina žemès ūkio dirvožemių drèkumą.

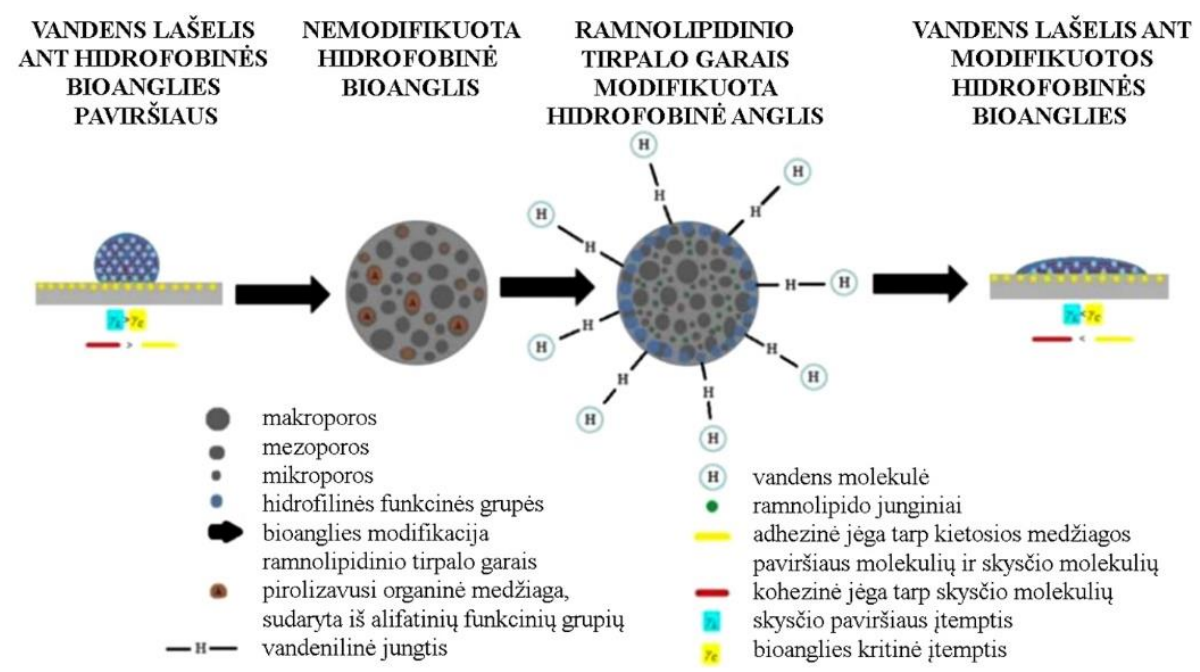

1.15 pav. Schema, vaizduojanti ramnolipidinio tirpalo garų poveikị hidrofobinès bioanglies hidrofiliškumui didinti (autorès paveikslas)

Fig. 1.15. Diagram showing the effect of the steam of rhamnolipid solution on increasing the hydrophilicity of hydrophobic biochar (author's figure)

Siekiant pagerinti adsorbcines bioanglies savybes, dažnai taikoma praktika bioanglies gamybos metu, yra paviršiaus ploto didinimas naudojantis aktyvacija garais. Aktyvacija garais gali pagerinti funkcinių grupių kieki, išlaisvinant lakiąą medžiagą iš užsikimšusių bioanglies porų ir potencialiai modifikuojant funkcines paviršiaus grupes. Garai keičia bioanglies savybes šalinant nevisiško kaitinimo produktus pirolizès metu ir oksiduojant anglies paviršių. Kitu tyrimu (Gray et al., 2014) nustatyta, kad bioanglis, paveikta prisotintais vandens garais, prarado savo pradini hidrofobiškumą po 7 dienų. Tai buvo siejama su erdvès tarp poru užpildymu ir porų paviršiaus oksidacija

Taigi inžineriniai metodai, gerinantys bioanglies savybes, gali būti fizikiniai, cheminiai ar biologiniai. Neseniai buvo pasiūlyta naudoti lietaus vandenį, kuris galètu potencialiai pakeisti bioanglies savybes dẻl drékumo didinimo. Taip pat vieną iš būdų galima laikyti biologines aktyviąsias paviršiaus medžiagas, mažinančias vandens paviršiaus įtemptị. 


\subsection{Bioanglies naudojimas oro valymo technologijose}

Per paskutinius kelis dešimtmečius padidèjusios atmosferinių teršalų emisijos tapo viena svarbiausių problemų, su kuria dabartiniame šimtmetyje susiduria pasaulio šalys. Nustatyta, kad oro tarša sukèlè 420000 priešlaikinių žmonių mirčių Europos Sajungoje (ES) vien 2010 m. (Baltrėnas et al., 2016). Lakiujų organinių junginių (LOJ) emisijos sudaro apie 7 \% visų atmosferos teršalų, kurių kiekis palaipsniui didejja nuo paskutinio šimtmečio pradžios. Nors bendros LOJ emisijos išlieka palyginti nedidelès, jų išmetami kiekiai iš pramonès ir namų ūkių gali sukelti ilgalaikị pavojų žmonių sveikatai (vėži, galvos skausmą, vizualinius sutrikimus), gyvūnams ir aplinkai. Jie taip pat turi poveiki atmosferai bei ekosistemoms (Zhu et al., 2016). Kai kurie LOJ prisideda prie stratosferos ozono išeikvojimo (kaip kad chlorfluorangliavandeniliai), toksiško ir karcinogeninio poveikio žmogaus sveikatai ir globalinio šiltnamio efekto (Singh et al., 2013).

Amoniako emisijos susidaro kaip šalutinis produktas iš pramonès procesų, kaip kad nuotekų valymas, kompostavimas, gyvulininkystè, žemès ūkis (mineralinių trąšų naudojimas) ir naftos perdirbimas (Tsang et al., 2017). Gyvulininkystė sukuria daugiau kaip 70 \% amoniako emisijų Europoje (Unece, 2019). Mineralinių trąšų naudojimas žemès ūkyje sudaro $20 \%$ amoniako emisijų, o transportas ir pramone - tik iki $10 \%$. Kasmet ES susidaro 3,1 mln. $t$ amoniako emisijų (Zeng et al., 2018). Jo emisijos sukelia nemalonius kvapus, galvos skausmą, bronchų dirginimą bei akių ir odos deginimo pojūtị (Tsang et al., 2017). Šiuo metu siūloma mažinti amoniako emisijas ribojant karbamido trąšu naudojimą, pakeičiant mineralinių trąšų naudojimą gyvulių ekskrementais bei pritaikant oro valymo irenginius - skruberius - dideliuose gyvulininkystès ūkiuose (Unece, 2019).

2016 m. lakiujų organinių teršalų kiekis (tūkst. t) atmosferos ore siekè 30,9 tūkst. t (1.8 lentelè). Matyti, kad 2017 m. ir 2018 m. LOJ išmetamų i atmosferą kiekis mažèjo ir atitinkamai siekè 29,5 bei 29,9 tūkst. t.

1.8 lentelè. İ atmosferą išmestų lakiųjų organinių junginių kiekis 2016-2018 m. (Aplinkos apsaugos agentūra, 2020)

Table 1.8. Amount of volatile organic compounds emitted into the atmosphere in 20162018 (Aplinkos apsaugos agentūra [Environmental Protection Agency] 2020)

\begin{tabular}{|c|l|l|l|}
\hline Teršalas & \multicolumn{1}{|c|}{$2016 \mathrm{~m}}$. & \multicolumn{1}{|c|}{$2017 \mathrm{~m}}$. & \multicolumn{1}{c|}{$2018 \mathrm{~m}}$. \\
\hline Lakieji organiniai teršalai & 30,9 & 29,5 & 29,9 \\
\hline
\end{tabular}


LOJ ir kvapus turintys junginiai gali būti pašalinami iš dujų srauto naudojantis fizikiniais, cheminiais ar biologiniais procesais grindžiamomis technologijomis (katalitinè ar fotokatalitinè oksidacija, adsorbcija, biofiltracija, kondensacija, absorbcija) (Pirola, Mattia, 2021). Vienos ar kitos technologijos pasirinkimas priklauso nuo LOJ kilmès ir koncentracijos bei dujų srauto greičio. Absorbcijos procesas gali būti pigus ir saugus, ypač jei naudojamas tik vanduo kaip tirpiklis. Dujų absorbcija naudinga atskiriant dujinius mišinius, šalinant priemaišas ir gali atstatyti vertingus cheminius junginius. Šiuo metu auga ekologiškų ir aplinkai palankių technologijų poreikis, dèl to didèja susidomèjimas biologinemis alternatyvomis (Morral et al., 2020). Keletas biologiniais procesais paremtų konfigūracijų (pvz., biofiltrai, bioskruberiai) buvo naudojama LOJ šalinti iš oro ịvairiomis sąlygomis (Bravo et al., 2017).

Biologinis metodas yra efektyvus ir ekonomiškas mažų koncentracijų kvapų, randamų atliekų dujose, valymo būdas. Šis metodas taip pat tinkamas komposto dujoms valyti. Oro fazès bioreaktoriai (biofiltrai) gali valyti didelio tirpumo ir mažo molekulinio svorio LOJ bei neorganinius junginius. Mikrobiologinès oksidacijos šalutiniai produktai yra vanduo, anglies dioksidas, mineralinès druskos, kai kurie lakieji organiniai junginiai ir mikrobiologine biomase (Environment Agency, 2013). Tipiné biofiltro konfigūracija pateikta 1.16 paveiksle. Užterštas dujų srautas pereina per kondicionierių dẻl dalelių pašalinimo ir sudrèkinimo (Ardjmand et al., 2005). Paskui dujų srautas patenka pro bioịkrovos (dirvožemio, durpių, kompostuotos organinès medžiagos) apačią. Bioịkrova teikia paviršių mikroorganizmams prisitvirtinti ir augti. Kai oras pereina pro filtrą, jo teršalu koncentracija yra veikiama advekcijos, dispersijos, adsorbcijos, absorbcijos ir biologinių procesų (1.16 pav.). Teršalai pradedami šalinti biofiltre nuo teršalų pernešimo iš oro ị vandens fazę, po kurios vyksta teršalų adsorbcija ant bioịkrovos arba absorbcija ant vandens sluoksnio ir galiausiai teršalų skaidymas bioplèvelèje.
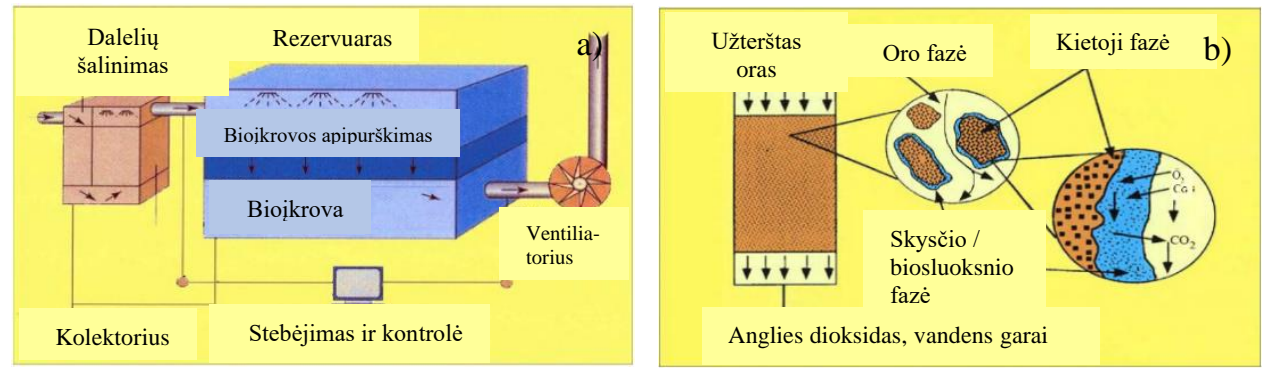

1.16 pav. Biofiltro sudètis ir procesai: a) tipinè konfigūracija;

b) vidinis biofiltro mechanizmas (Ardjmand et al., 2005)

Fig. 1.16. Biofilter composition and processes: a) typical configuration;

b) internal biofilter mechanism (Ardjmand et al., 2005) 
Vykstant biofiltracijai tiriami teršalai turi būti vandenyje tirpūs, bioskaidomi ir netoksiški. Keletas atliktų eksperimentinių tyrimų parodè, kad biofiltrai yra tinkami LOJ, vandenilio sulfidui bei amoniakui šalinti. Dažnai teigiama, kad biofiltrai yra tinkami tik vidutinę ar žemą Henrio konstantą $\left(\mathrm{K}_{\mathrm{H}}\right)$ turintiems LOJ valyti (Cheng et al., 2016). LOJ, kuriems yra būdingos aukštos $K_{H}$, jų pašalinimo geba yra ribota. 1.10 lenteleje pateikiama LOJ klasifikacija remiantis $\mathrm{K}_{\mathrm{H}}$, kurios gali būti naudojamos jų šalinimo efektyvumui ịvertinti biofiltruose dèl masès pernašos. Nepaisant to, kad junginiai su didele $\mathrm{K}_{\mathrm{H}}$ tendencingai turi mažesnius šalinimo greičius, biofiltracija vis dar gali būti efektyvi labai hidrofobiškiems junginiams, kaip kad heksanas ar alfa pinenas, šalinti.

1.10 lentelè. Lakiujų organinių junginių drèkumo laipsnis ir Henrio dèsnio konstantos (Cheng et al., 2016)

Table 1.10. Wettability degree of volatile organic compounds and Henry's law constants (Cheng et al., 2016)

\begin{tabular}{|l|l|l|l|}
\hline \multirow{4}{*}{ Drėkumo laipsnis } & \multicolumn{1}{|c|}{ Hidrofiliniai } & \multicolumn{1}{|c|}{$\begin{array}{c}\text { Vidutiniškai } \\
\text { hidrofiliniai }\end{array}$} & Hidrofobiniai \\
\hline \multirow{5}{*}{ LOJ } & Dimetilsulfidas & Alfa - pinenas & Etenas \\
\cline { 2 - 4 } & Dimetildisulfidas & $\begin{array}{l}\text { Benzenas, toluenas, } \\
\text { etilbenzenas, } \\
\text { ksilenas }\end{array}$ & Etanas \\
\cline { 2 - 4 } & Vandenilio sulfidas & Dichlorometanas & Heksanas \\
\cline { 2 - 4 } & Metanolis & Izopropilbenzenas & Metanas \\
\cline { 2 - 4 } & Metiletilketonas & Stirenas & Pentanas \\
\cline { 2 - 4 } & Formaldehidas & Chlorobenzenas & Acetilenas \\
\cline { 2 - 4 } & Acetonas & Trichlorometanas & Cikloheksanas \\
\hline $\begin{array}{l}\text { Henrio dėsnio }\left(\mathrm{K}_{\mathrm{H}}\right) \\
\text { konstanta } 25^{\circ} \mathrm{C} \\
\text { temperatūroje }\end{array}$ & $0,0001-0,099$ & $0,1-0,99$ & $1-70$ \\
\hline $\begin{array}{l}\text { Masės pernešimo } \\
\text { apribojimo rizika }\end{array}$ & \multicolumn{3}{|l}{} \\
\hline Toksiškumo rizika & \multicolumn{3}{|l}{} \\
\hline
\end{tabular}

Bendras biofiltro efektyvumas daugiausia ịvertinamas pagal bioịkrovos savybes (poringumą, sutankinimo laipsnị, vandens laikomają gebą, mikrobiologinę populiaciją) (Environment Agency, 2013). Temperatūra, pH, maistinių medžiagų koncentracijos, vandens kiekis ir santykinis oro drègnumas yra svarbiausi parametrai, turintys ịtakos biofiltro šalinimo gebai. Ypatingai 
svarbus parametras yra vandens kiekis, jis privalo būti kontroliuojamas, kad būtų galima išvengti bioịkrovos per didelio sudrèkimo arba išsausejjimo. Nustatyta, kad $75 \%$ visų biofiltracijos problemų sukelia prastas ịkrovos drékinimas. Taip pat turètų būti nuolatos tikrinama santykinè oro drègmé dèl ịkrovos išsausejjimo problemos.

Kita problema biofiltre - per didelis drègmès kiekis bioịkrovoje. Vandens perteklius slopina deguonies ir hidrofobinių teršalų pernešimą į bioplèvelę, dèl to skatinamas anaerobinių zonų formavimasis, mažeja reakcijos greitis. Perteklinis vanduo gali skatinti dvokiančių emisijų susidarymą dèl deguonies stygiaus (Mudliar et al., 2010). Jei esti vandens perteklius, ikrovos poros vietomis užsikemša. Tai mažina aerobinių mikroorganizmų aktyvumą, didina aerodinaminị pasipriešinimą ir mažina teršalų šalinimo efektyvumą.

Biofiltro ịkrovos drègmès kiekis yra svarbus veiksnys biofiltro veikimui, nes vanduo reikalingas mikroorganizmų vystymuisi ir jų normaliam metaboliniam aktyvumui (Kauselya et al., 2015). Dèl to tinkamo drègmès kiekio išlaikymas bioịkrovoje yra labai svarbus vertinant biofiltro efektyvumą (Mansoori et al., 2017). Papildomas drègmès tiekimas ị biofiltrą reikalingas, nes mikroorganizmų vykdoma biooksidacija yra egzoterminè reakcija, todèl terpès viduje gali vykti sausèjimas (Mudliar et al., 2010). Siekiant išlaikyti reikalingą drègmès kiekị bioịkrovoje, ji turètų būti papildomai drèkinama iš biofiltro viršaus.

Drègmès kiekis biofiltre dažnai palaikomas tiekiant sudrèkintą dujų srautą. Drègmè gali būti tiekiama ị sistemą dviem būdais: drékinant dujų srautą arba tiesiogiai tiekiant vandenị ant biofiltro paviršiaus. Dujų srautas drèkinamas prieš biofiltro veikimą. Paprastai dujų prisotinimo laipsnis turètų siekti mažiausiai $95 \%$, o prisotinimas nuo $99 \%$ iki $100 \%$ laikomas optimaliu. Ant biofiltro paviršiaus taip pat gali būti purškiama. Taip pat turi būti atsižvelgiama ị vandens lašelių dydị. Paprastai siūlomas vandens lašelių skersmuo mažesnis už $1 \mathrm{~mm}$, kad būtų galima išvengti biofilltro suslègimo. Pažangesnę sistemą sudaro ịkrauti elementai, kurie fiksuoja filtracijos terpès svorị ir yra sujungti su drèkinimo sistema (Mudliar et al., 2010).

Optimalus drègmès kiekis kinta priklausomai nuo skirtingos bioịkrovos medžiagos, kurios skiriasi savo paviršiaus plotu, poringumu ir kitais veiksniais. Drègmès kiekis bioịkrovoje skatina mikrobiologinị vystymąsi, kuris optimaliam biofiltro veikimui turètų siekti 30-60\% pagal svorị (Mansoori et al., 2017; Mudliar et al., 2010). Jis turètų siekti nuo 50 iki $60 \%$ naudojant kompostą ir nuo 60 iki $70 \%$ naudojant durpes (Kauselya et al., 2015). Palyginti didele vandens laikomaja geba pasižymi poliuretano puta ir tai galètų būti aiškinama atvirujų porų struktūra. Dumblo bioanglis ir aktyvintoji anglis sulaiko daugiausia vandens ir tai yra svarbu vandens išsaugojimui prastai drèkinamuose biofiltruose (Dorado et al., 2010). 


\subsection{Kapiliarinio kilimo greičio teoriniai tyrimai}

Kapiliarinis kilimas poringojoje medžiagoje yra dažnas fenomenas tiek gamtinėse, tiek pramoninèse sistemose. Pramoneje šis fenomenas pasitaiko naftos išgavimo, civilinès inžinerijos, tekstilès dažymo, spausdinimo dažais ir daugelyje kitų sričių. Daugelis modelių, apibūdinančių poringają medžiagą, remiasi prielaida, kad tarpai tarp porų atitinka kapiliarinių vamzdelių rinkinị. Tai apibūdinama ir anksčiau minètuose Lucas (1918) ir Washburn (1921) darbuose, kurie tyrè dinaminį skysčio skverbimąsi ị poringosios medžiagos cilindrinius kapiliarus. Kapiliarinio vamzdelio analogas taip pat yra cilindrinis vamzdelis, kuris laikomas kaip netolygus, sinusoidiškai ribotas, tai yra kintančio skersmens.

Kai cilindrinis mažo skersmens stiklinis vamzdelis panardinamas ị vandenị, susiformuoja meniskas, kuris atspindi kontakto laipsnị tarp vandens ir vamzdelio sienelès (Or, Tuller, 2005). Kuo mažesnis vamzdelio spindulys, tuo didesnio vingiuotumo laipsnis bei slègių skirtumas susidaro tarp vandens ir oro paviršiaus. Dažnai naudojamas konceptualus vandens sulaikymo poringojoje medžiagoje modelis siejasi su supaprastintu dirvožemio porų tarpų paveikslu, vadinamu kapiliarų rinkiniu. Dirvožemio porų kaip pusiausvirujų cilindrinių kapiliarų vaizdavimas supaprastina tarpų tarp dirvožemio porų modeliavimą, kuris stipriai siejasi su kapiliarinio kilimo lygtimi.

Kai slègis vandens pusėje $P_{w}$ yra mažesnis už atmosferos slègi $P_{0}$, šis slègių skirtumas skatina vandenị kilti kapiliare tol, kol kapiliarinė jèga subalansuojama. Kapiliarinio kilimo pusiausvirasis aukštis cilindriniame vamzdelyje su kontakto laipsniu $\theta$ yra lygus:

$$
h=\frac{2 \gamma \cos \theta}{\rho g r},
$$

čia $h$ - skysčio pakilimo aukštis, $\mathrm{m} ; g$ - gravitacijos pagreitis, $\mathrm{m} / \mathrm{s}^{2} ; \rho$ - skysčio tankis, $\mathrm{kg} / \mathrm{m}^{3} ; \gamma$ - skysčio paviršiaus ịtemptis, $\mathrm{N} / \mathrm{m} ; \boldsymbol{\theta}$ - kontakto laipsnis tarp skysčio ir vamzdelio, ${ }^{\circ} ; r$ - vamzdelio spindulys, $\mathrm{m}$.

Vašburno teorija rodo, kad jei poringoji kietoji medžiaga kontaktuoja su skysčiu ir nėra įmerkiama ị skystị, skystis liečia kietosios medžiagos paviršių ir skysčio kilimas kietosios medžiagos porose vyks dẻl kapiliarinio veiksmo, kuris nurodomas Vašburno lygtimi:

$$
t=A m^{2},
$$

čia $t$ - laiko tarpas, po kurio ịvyksta kietosios medžiagos ir skysčio kontaktas, s; $m$ skysčio, prasisunkusio pro kietosios medžiagos paviršių, masè, g; $A$ - konstanta, kuri priklauso nuo skysčio ir kietosios medžiagos savybių:

$$
A=\frac{\mu}{c \times \rho^{2} \times \gamma \times \cos \theta},
$$


čia $\mu$-skysčio dinaminè klampa, $\mathrm{N} \cdot \mathrm{s} / \mathrm{m}^{2} ; \gamma$-skysčio paviršiaus įtemptis, $\mathrm{N} / \mathrm{m} ; c-$ medžiagos konstanta, kuri priklauso nuo kietosios medžiagos poringosios architektūros.

Atliekant Vašburno eksperimentą, turètų būti naudojamas skystis su žinomu tankiu $\rho$, klampa $\mu$ ir paviršiaus įtemptimi $\gamma$. Vašburnas nustatè laiko priklausomybę nuo skysčio kilimo aukščio pavieniame tiesiame kapiliare, kurio spindulys yra $r$. Tos lygties išvedimas yra anksčiau mineta Laplaso lygtis. Po to buvo išvesta Vašburno lygtis, kuri dar kitaip yra vadinama Luko ir Vašburno (L-W) lygtimi, sulyginant kapiliarinio slėgio skirtumą su slègio praradimu dèl vidinės frikcijos:

$$
h^{2}=\frac{r \gamma \cos \theta}{2 \mu} t
$$

Lukas, nežinodamas Vašburno darbo, išvedè nepriklausomai tą pačią lygtị. Pagrindiniai kombinuotos Luko ir Vašburno lygties trūkumai yra šie:

- poringoji medžiaga laikoma kaip pavienių, tiesių linijinių kapiliarų, turinčių spinduli $r$, rinkinys;

- gravitacijos jègos poveikis nėra įtraukiamas ị skaičiavimus;

- tariama, kad yra laminarusis skysčio tekëjimas;

- nèra ịvertinamas garavimas iš poringosios medžiagos;

- kontakto laipsnis varijuoja priklausomai nuo naudojamo skysčio;

- nėra ịvertinama skysčio adsorbcija kietosios medžiagos paviršiumi;

- absorbcijos inercija, kuri siejasi su judančio skysčio mase, nèra ịvertinama;

- esant ilgesniems laiko tarpams Luko ir Vašburno lygtis negali iki galo atspindèti skysčio kapiliarinio kilimo;

- nèra įtraukiamas dalelių brinkimo efektas.

Metodai, gerinantys L-W lygtị, ịtraukia kontakto laipsnio pokyčius, porų spindulio netolygumą, poru vingiuotumą, neapskritaji porų skerspjūvị, inercijos poveikị ypač anksčiausiose kapiliarinio kilimo proceso stadijose (Tsunazawa et al., 2016). Vèlesniuose kapiliarinio kilimo aukščio modeliuose vertinama, kaip brinkimo efektas veikia kapiliarumo procesą įvairiose medžiagose (vaistuose, tekstilèje, medienoje, celiuliozinèse kempinèse, maistiniuose biopolimeruose). Shi ir Gardner (2000) vertino brinkimo poveiki vandens kapiliarinio kilimo greičiui trijose medžiagose: polietilene, medienoje ir nailone. Buvo išvestas naujas modelis, apibūdinantis kapiliarinio kilimo greiti priklausomai nuo brinkstančio kapiliaro spindulio $r_{s}$ ) tūrinio medžiagos brinkimo $\delta_{v}$ ir energijos praradimo koeficiento $C$ :

$$
h^{2}=\frac{r_{s}^{2} \gamma \cos \theta}{2 \mu r} t-\frac{C \delta_{v}}{4 \mu \pi}\left(\frac{r_{s}}{r}\right)^{2} t .
$$

Brinkimo efektas šiame tyrime buvo nustatytas dviem pastebejjimais: temperatūros kilimu kapiliarinio kilimo proceso metu ir vidutinio kapiliaro $r$ 
skirtumais naudojantis mažos paviršiaus ịtempties poliniu skysčiu (metanoliu) ir mažos paviršiaus įtempties nepoliniu skysčiu (heksanu).

Markl et al. (2017) sukūrè naują modelị, apibūdinantị skysčio kapiliarinị kilimą vaistų tabletėse. Kai tabletės brinksta, didèja kapiliarinis pakilimo aukštis, o išbrinkusio kapiliaro spindulys $r_{s}$ mažèja (1.17 pav.). Skysčio kapiliarinio kilimo poringojoje medžiagoje modelis aprašomas taip:

$$
h^{2}=\frac{2 P_{c}}{\varepsilon_{0} \mu} \int_{0}^{t} K\left(t^{\prime}\right) d t^{\prime}
$$

čia $\varepsilon_{0}-$ pradinis medžiagos poringumas, $\% ; K$ - medžiagos laidumas. Šiame modelyje būdingasis laidumas $K$ kinta kartu su laiku.

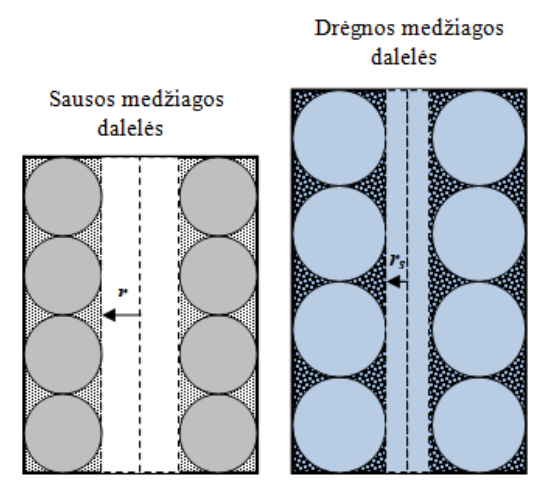

1.17 pav. Dalelių brinkimo schema: $r$ - kapiliaro spindulys; $r_{s}-$ išbrinkusio kapiliaro spindulys (autorès paveikslas)

Fig. 1.17. Particle swelling scheme: $r$ - capillary radius; $r_{s}-$ swelled capillary radius (author's figure)

Celiuliozès poringosios medžiagos, kai jos kontaktuoja su vandeniu, absorbuoja skystị ir tuo pačiu metu brinksta. Celiuliozè yra polimeras, kurio grandinès yra susijungusios vandenilinèmis jungtimis ir vandens molekulès dalyvauja su adsorbcinėmis vietomis taip sukeldamos polimero tūrio didejimą. Tokia fizikinè ir cheminè vandens bei poringosios struktūros sąveika vadinama higroskopiniu plètimusi. Viename iš tyrimų kapiliarinis skysčio kilimas vėlesnèse stadijose celiuliozinèje poringoje terpèje apibūdinamas Darsi dèsniu (Ha et al., 2018):

$$
u \approx \frac{\gamma^{3}}{\mu(\rho g)^{2} r h^{3}}
$$


čia $u$ - tūrinis vidutinis Darsi greitis, $\mathrm{m} / \mathrm{s}$. Teorija remiasi pagrindinèmis prielaidomis, kad porų slègis didejja kartu su vandens kiekiu, t. y. skysčio kiekiu porų tuštumose, tad poros pradeda brinkti.

\subsection{Kapiliarinio kilimo greičio skaitinis modeliavimas}

Skysčio tekèjimo aukštis pavieniame kapiliare taip pat vadinamas Jurino aukščiu, kuri apibūdino Džeimsas Jurinas (1684-1750). Po dviejų šimtmečių Lukas ir Vašburnas apibūdino kapiliarini kilimą poringoje sistemoje, sudarytoje iš tiesių vienodo spindulio kapiliaru tinklo. Vèliau kapiliarinis tekejjimas poringose sistemose buvo modeliuojamas taikant skirtingus kompiuterinius modelius, kaip kad COMSOL Multiphysics, Flow-3D, ANSYS CFX.

Gosselin et al. (2015) tyrè kapiliarinio tekèjimo dinamiką vamzdyje naudojantis COMSOL Multiphysics. Buvo parodyta kvadratinès kapiliarinio kilimo šaknies priklausomybė bei nustatytas Luko ir Vašburno dèsnis cilindriniams vamzdžiams. Taip pat buvo tiriamos skirtingos geometrinès konfigūracijos, kaip kad stabdantys ir trišakiai vožtuvai. Be to, buvo atliktas 3D atvaizdavimas mikrokanaluose su aštriais kampais. Remiantis 1.10 lygtimi greitis $u$ buvo išreikštas taip:

$$
u=\sqrt{\frac{r \gamma \cos (\theta)}{\mu 8}} \frac{1}{\sqrt{t}}
$$

1.18 paveiksle parodytas modeliavimas trišakiame vožtuve ir jo palyginimas su eksperimentiniais duomenimis. Buvo nustatyta, kad skysčio dinamika vožtuve, sumodeliuota COMSOL programa, gerai atitiko eksperimentinius rezultatus.

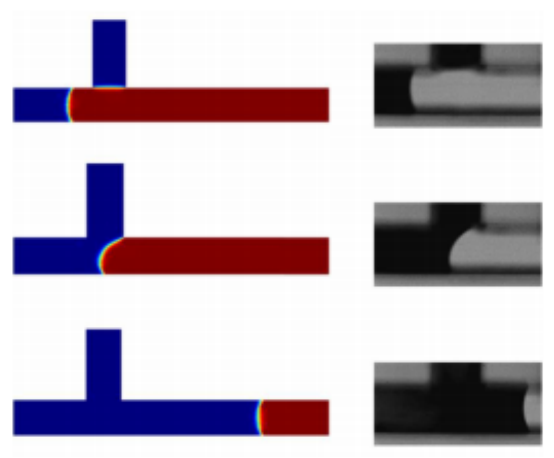

1.18 pav. Sumodeliuota skysčio dinamika trišakiame vožtuve (Gosselin et al., 2015)

Fig. 1.18. Simulated fluid dynamics in a three-way valve (Gosselin et al., 2015) 
FLOW-3D programa turi pagerintą paviršiaus ịtempties modelị, ị kurị įeina kompleksinè geometrija, sieneliu adhezija ir paviršiaus įtempties koeficientai. Kitu tyrimu (Hirt, 2017) buvo modeliuojamas skysčio kilimas 2D angoje, kurios plotis - 0,1 cgs, o storis $w-0,05$. Skysčio tankis buvo 1, paviršiaus įtempties koeficientas -100 , skysčio įtemptis $-0,5$, o kontakto kampas su sienele $-30^{\circ}$. Sienelès adhezija buvo subalansuota gravitacinès jègos vertikalia kryptimi. Pakilusio skysčio tūris $V$ buvo apskaičiuotas lygtimi:

$$
V=\frac{\gamma \cos (30) w}{\rho g}
$$

Šiuo atveju teorinis tūris buvo 0,00433. Modeliavimas naudojant tolygų tinklelį lėmè skysčio tūrị, lygų 0,0044, arba 1,6 \% didesnị už teorinị. Pakartojant modeliavimą su 20 elementų tinkleliu, skystis pakilo iki 0,00428 tūrio, arba $1,15 \%$ mažiau teorinès vertès. Xu ir Guetari (2004) naudojo ANSYS CFX skysčio tekejimui modeliuoti kapiliariniame vamzdelyje. Rezultatų, gautų CFX programa, palyginimas su eksperimentiniais rezultatais ir analitiniais sprendiniais parodè gerą suderinamumą. CFX rezultatai geriau atitiko eksperimentinius duomenis nei Luko ir Vašburno lygtis (1.19 pav.).

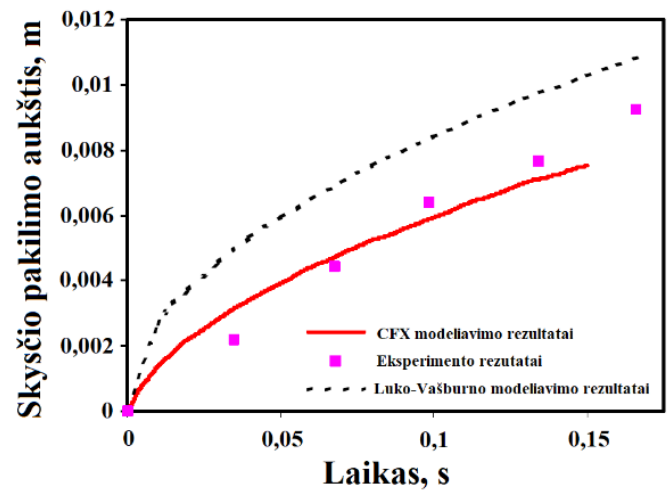

1.19 pav. CFX rezultatu palyginimas su eksperimentiniais duomenimis bei Luko ir Vašburno lygtimi (Xu, Guetari, 2004)

Fig. 1.19. Comparison of CFX results with experimental data and the LucasWashburn equation (Xu, Guetari, 2004)

Skaičiuojamoji skysčiu dinamika (CFD) remiasi Navier ir Stokes lygčių sprendimu, naudojantis skaičiuojamosiomis technikomis. Pagrindinès šio modelio lygtys buvo išspręstos naudojantis komerciniu CFD kodu CFX iš ANSYS. Baigtinių elementų analize ir lygio metodas taikomi Navier ir Stokes lygtims spręsti, įtraukiant paviršiaus ịtemptị ir dviejų fazių tekejjimo charakteristikas. 


\subsection{Tvarumo aspektai bioanglies modifikavimo technologijose}

Kadangi bioanglis yra gaunama tiesiogiai pirolizès būdu iš didelio spektro biomasès ir turi ribotą paviršiaus funkcinių grupių skaičių bei poringumą, reikalingas mechanizmas jai, kaip funkcinei medžiagai, modifikuoti ir naudoti. Kadangi galima lengvai koreguoti funkcines grupes ir poringumą, bioanglis yra efektyvi medžiaga ir plačiai naudojama. Koreguojant funkcines grupes oksidacijos, amininimo, sulfonacijos ar rekombinacijos būdais, ant bioanglies paviršiaus gali susiformuoti gausios funkcinès grupès (pvz., $\mathrm{C}=\mathrm{O}, \mathrm{OH}, \mathrm{COOH}$, $\mathrm{NH}_{2}, \mathrm{SO}_{3} \mathrm{H}$ ), metalų nanodalelès bei neorganinès nanostruktūros. Tai yra ypač svarbu keičiant bioanglies naudojimą kaip funkcinę medžiagą. Be funkcinių grupių, taip pat svarbus yra ir bioanglies poringumas. Taikant įvairius cheminius, fizinius ir biologinius modifikacijos metodus, gali būti sukuriamas bioanglies poringumas su dideliu paviršiaus plotu bei kontroliuojamu dalelių dydžio pasiskirstymu, dèl ko gali didèti jos potencialus taikymo mastas (Liu et al., 2015).

Atsižvelgiant ị bioanglies panaudojimą (1.20 pav.), reikètų vystyti aplinkai palankius ir efektyvius būdus paviršiaus funkcinių grupių ir poringumo korekcijai. Dèl to bioanglies paviršiaus polingumas ir drëkumas gali būti lengvai kontroliuojami koreguojant paviršiaus funkcines grupes, taip sukuriant bioanglies medžiagas su skirtingais potencialiais pritaikymais. Nors bioanglies naudojimas igavo didelę reikšmę per gana trumpą laiko tarpą, anksčiau minèti iššūkiai ir klausimai vis dar išlieka. Išsprendus šias problemas galima dar geriau išplèsti jos praktinị naudojimą. Iš tikrụjų reikia įvertinti visus tvarios bioanglies kūrimo proceso elementus nuo pradinès medžiagos (biomasès) kilmès iki apdorojimo (katalizatoriai ir aktyvūs reagentai, sintezès žingsniai, energiniai poreikiai, tirpikliai ir kt.), $\mathrm{CO}_{2}$ emisijų ir junginių pasiskirstymo bei jų transformacijos. Svarbu atrasti būdus naudoti lignoceliuliozinès biomasès atliekas, kurios yra nekonkurencingos pasaulio mitybos grandineje, kas yra ypač svarbu tvarios bioanglies paieškai ir gamybai (Liu et al., 2015).

Ekonominę bioanglies naudą ūkininkas gauna tada, kai didèja žemès ūkio produkcija ir kartu mažèja trąšų naudojimas. Didejjant atliekų utilizavimo kainai ir atsinaujinančios energetikos planų reikalavimams, bioanglies produkcija ir jos naudojimas bei kartu atlieku valdymas taps daugiau ekonomiškai prieinamas. Ekonominis bioanglies produkcijos sistemu igyvendinimas yra svarbus produkto komercializacijai. Turi būti ịvertinti tokie veiksniai, kaip valdymo kainos, fiksuota bioanglies produkcijos kaina, mokesčiai ir pardavimas (Nsamba et al., 2015). Bioanglies produkcijos sistemų potencialas taip pat priklauso nuo naudojamos žaliavos, konversijos technologijos ir anglies sekvestracijos subsidijų itraukimo. 


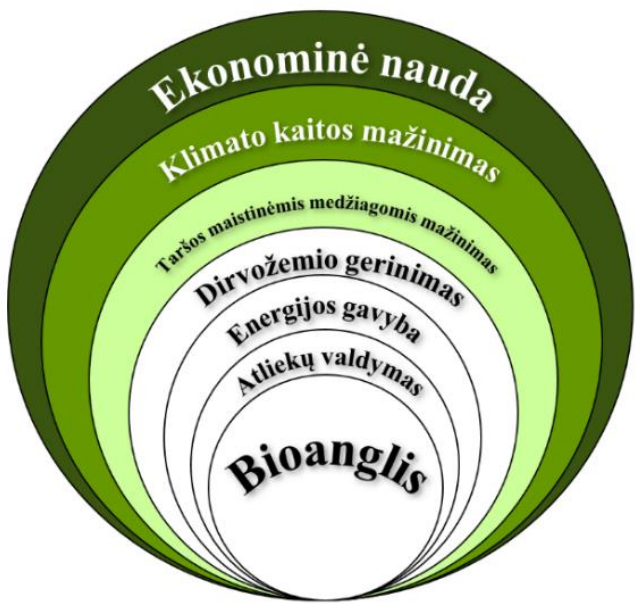

1.20 pav. Bioanglies teikiama nauda (Novotny et al., 2015)

Fig. 1.20. Benefits of biochar (Novotny et al., 2015)

Nustatyta, kad ekonominis pirolizès-bioanglies sistemos vertinimas stipriai priklauso nuo žaliavos produkcijos kainos, pirolizès ir anglies balanso. Naudinga naudoti bioanglị kaip dirvožemio gerintoją tuo atveju, jei bioanglies kaina rinkoje yra gana maža ir egzistuoja anglies balansas. Kiti nurodo, kad bioanglies kaina siejasi su jos produkcijos temperatūra. Gaunama nauda priklauso nuo bioanglies pardavimo kainos, pvz., bioanglies kaina gali siekti $185 € /$ t, kai pirolizès temperatūra yra $300{ }^{\circ} \mathrm{C}$, ir apie $236 € /$ t, kai temperatūra siekia $450{ }^{\circ} \mathrm{C}$ (Oni et al., 2019). Bioanglies gamybai dažniausiai naudojamas procesas yra lètoji pirolizè dèl palyginti didelès bioanglies išeigos ir $50 \%$ mažesnès fiksuotos ir valdymo biomasès apdorojimo kainos, lyginant su greitaja pirolize (Ahmed et al., 2016). Globaliu mastu vidutine bioanglies kaina siekia $2,21 € / \mathrm{kg}$. Ši kaina varijuoja nuo labai žemos $(0,08 € / \mathrm{kg})$ Filipinuose iki labai aukštos $(7,39 € / \mathrm{kg})$ Jungtinėje Karalysteje (Ahmed et al., 2016). Matoma, kad bioanglies rinkos kaina stipriai varijuoja nuo bioanglies gamybos vietos ir pirolizès sąlygų.

Norint efektyviai išvalyti vandenị ar orą, reikia nustatyti minimalius reikalavimus adsorbentams, atsižvelgiant ì paviršiaus plotą, poringumą ir paviršiaus chemiją. Norint pelningai gaminti bioanglies adsorbentą, žaliavos ir apdorojimo procesas turi būti nebrangus (Siipola et al., 2020). Remiantis ankstesniais tyrimais apie ekonomiškai prieinamas žaliavas bioanglies gamybai, tam tinka ịvairios miško pramonès atliekos (pjuvenos, žievės likučiai). Taip pat reikšmingos yra padidejusios išlaidos, atsirandančios dèl cheminių medžiagų naudojimo. Gaminti chemiškai aktyvintą angli nuotekoms valyti gali būti neekonomiška, nes reikia didelio cheminių medžiagų kiekio, o naudotos aktyvintos anglies pakartotinis naudojimas gali būti neįmanomas. 


\subsection{Pirmojo skyriaus išvados ir disertacijos uždavinių formulavimas}

1. Iki šiol kapiliarinio kilimo greičio modeliuose poringosios medžiagos poros buvo vaizduojamos kaip tiesūs kapiliariniai vamzdeliai, tačiau, kaip parodè naujausi tyrimai, realiose sąlygose poringos medžiagos kapiliarai yra vingiuoti. Be to, celiuliozės turinčios medžiagos, prisotintos skysčio, turi tendenciją brinkti. Yra du patvirtinti kapiliarinio veiksmo fenomeno matematinio modeliavimo būdai. Taikant senesnị ir tradiciškesnị metodą naudojama Luko ir Vašburno lygtis, kurioje poringa terpe laikoma kaip tokio paties spindulio išlygiuotų kapiliarinių vamzdelių pluoštas. Naujesni metodai ịvertina dalelių brinkimo efektą ar paviršiaus garavimo įtaką kapiliariniam kilimui.

2. Bioanglies hidrofiliškumo didejjimo tendencija, augant pirolizès temperatūrai, aiškinama didejjančiu bioanglies poringumu, paviršiaus plotu, porų išlaisvinimu nuo dervas sudarančių alifatinių junginių, garuojančių aukštesnejje temperatūroje, bei deguonies turinčių funkcinių grupių skaičiaus didèjimu.

3. Bioanglies drèkumui įvertinti taikomi šie metodai: vandens lašelio skverbimosi laiko testas, etanolio lašelio molingumo testas ir kontakto laipsnio analizè. Dažnai bioanglies tyrimuose vietoj vandens lašelio skverbimosi laiko testo siūloma naudoti etanolio lašelio molingumo testą dèl ilgo vandens lašelio skverbimosi laiko ant hidrofobinès bioanglies paviršiaus. Kita vertus, šių testų rezultatai negali suteikti fizikinès reikšmès drèkumo teorijoje.

4. Atsižvelgiant ị cheminių metodų, taikomų bioanglies sorbcijai didinti, netvarumą ir naudojamų cheminių medžiagų, kaip kad dujiniai ir skysti oksidantai, agresyvumą, reikètų plètoti aplinkai palankius ir efektyvius būdus bioanglies hidrofiliškumui didinti.

5. Bioanglis ir komercinè aktyvintoji anglis sulaiko daugiausia vandens, ir tai yra svarbu sulaikant vandeni prastai drékinamuose biofiltruose.

6. Dirvožemio drèkumas yra sudètingas procesas, kurị gali veikti tiek aplinkos (temperatūra, vejjas), tiek dirvožemio savybès (pvz., hidrofobinès organinès anglies kiekis, mineralinè sudètis). Taip pat drèkumui ịtaką gali daryti tiek dirvožemio tręšimas, tiek jo dirbimo būdas, kuris gali kisti pagal laiko skalę.

Atlikus mokslinès literatūros analizę nustatyta, kad dar yra neišspręstų klausimų bioanglies tematika, todèl reikia:

1. Atlikti organinių ir neorganinių skysčių kapiliarinio kilimo greičio pušies medienos bioanglyje teorinius tyrimus.

2. İvertinti laiko ir temperatūros poveikị lignoceliuliozinès bioanglies savybėms bei prognozuoti jos drèkumą bei vandens laikomają gebą remiantis kitomis jos fizikinèmis ir cheminèmis savybèmis.

3. Nustatyti bioanglies drèkumo ịvertinimo metodų tinkamumą, tikslumą ir tarpusavio ryšị. 
4. Pagerinti bioanglies fizikines ir chemines savybes modifikuojant ją termofizikiniais bei cheminiais metodais.

5. Ivvertinti ramnolipidinio tirpalo garais modifikuotos bioanglies gebą didinti lakiujų organinių ir neorganinių junginių šalinimo efektyvumą biofiltre su kapiliarine drèkinimo sistema.

6. Nustatyti hidrofobinès žematemperatūrès bioanglies potencialą didinti smèlingojo rudžemio savybes.

7. Ivertinti vandens kapiliarinio kilimo aukštį skirtingų savybių lignoceliuliozinejje bioanglyje, taikant skaitinị modeliavimą. 


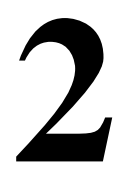

\section{Bioanglies fizikinių ir cheminių savybių nustatymas, modifikavimas, kapiliarinis kilimas, naudojimas dirvožemyje ir biofiltracijoje}

Skyriuje pateikiamos šios metodikos: skysčių kapiliarinio kilimo bioanglyje, bioanglies fizikinių ir cheminių savybių nustatymo, bioanglies modifikavimo termofizikiniais ir cheminiais būdais, bioanglies poveikio dirvožemio fizikinèms ir cheminèms savybėms, vandens kapiliarinio kilimo greičio bioanglyje skaitinio modeliavimo, bioanglies naudojimo biofiltracijoje šalinti lakiuosius organinius ir neorganinius junginius, bioanglies gebos didinti rudžemio fizikines ir chemines savybes.

Šia tematika autorè kartu su bendraautoriais paskelbė vieną publikaciją (Usevičiūtè, Baltrėnaitè, 2020). Gautas Lietuvos Respublikos patentas (Baltrėnas et al., 2019) „Bioanglies hidrofiliškumo didinimo ịrenginys ir būdas“. 


\subsection{Kapiliarinio kilimo greičio teoriniai tyrimai}

Skysčių kapiliarinio kilimo poringaja medžiaga tyrimų istorija siekia pionierinị Vašburno darbą, kuris nustate, kad skysčio, prasiskverbusio pro poringają medžiagą, tūrio priklausomybè nuo laiko apibrèžiama laiko kvadratine šaknimi. Nuo to laiko buvo padaryta Vašburno lygties modifikacijų, nes ankstesni modeliai turejjo prastą atitiktį natūraliai poringajai medžiagai. Šio tyrimo tikslas - îvertinti kapiliarinio kilimo mechanizmą bioanglyje, ì modelị ịtraukiant vingiuotus kapiliarus ir medžiagos brinkimo efektą. Kapiliarinio kilimo greičio, įtraukiant kompozito parametrą (srovès vingiuotumą ir porų formą), padidinta schema pavaizduota 2.1 paveiksle. Tai yra svarbu, nes daugelyje tiek pramoninių, tiek biologinių procesų medžiaga skysčio kapiliarinio kilimo metu deformuojasi, kai skystis pradeda ja tekèti.

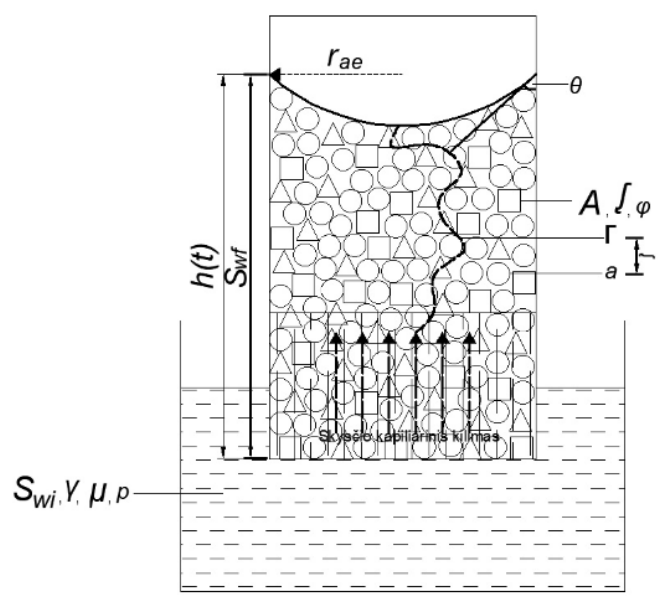

2.1 pav. Kapiliarinio kilimo modelio schema: $h(t)$ - skysčio kapiliarinio kilimo aukščio priklausomai nuo laiko funkcija; $A$ - medžiagos skerspjūvio plotas; $r_{a e}$-vidutinis efektyvusis kapiliaro spindulys; $\theta$ - kontakto laipsnis tarp medžiagos ir skysčio; $\rho-$ skysčio tankis; $\mu$-skysčio dinaminè klampa, $\gamma$-skysčio paviršiaus įtemptis; $a$-poros apertūros forma; $\tau$ - srovès vingiuotumas; $\varphi$ - medžiagos poringumas; $S_{w i}$ - pradinè medžiagos prisotinimo skysčiu būsena; $S_{w t}$ - galutinè medžiagos prisotinimo skysčiu

būsena (autorès paveikslas)

Fig. 2.1. Scheme of a capillary rise model: $h(t)$ - function of the capillary rise height of a liquid as a function of time; $A$-cross-sectional area of the material; $r_{a e}$ - the mean effective capillary radius; $\theta$ - the degree of contact between the substance and the liquid; $\rho$ - the density of the liquid; $\mu$ - dynamic viscosity of the liquid, $\gamma$ - surface tension of the liquid; $a$-shape of the aperture of the pair; $\tau$-current curvature; $\varphi$ - porosity of the material; $S_{w i}$ - initial state of liquid saturation of the substance; $S_{w t}$ - final state of liquid saturation of the substance (author's figure) 
Šiame tyrime kaip pradinė lygtis kapiliarinio kilimo aukščio $h$ priklausomybei nuo laiko $t$ modeliuoti buvo pasirinktas Cai et al. (2014) modelis, kuris ịvertina medžiagos masès priklausomybę nuo laiko kapiliarinio kilimo proceso metu. Šis modelis skiriasi nuo anksčiau minètu tuo, kad i ji įeina kompozito parametras $\xi$, pradine $S_{w i}$ ir galutine $S_{w f}$ skysčio prisotinimo būsenos:

$$
m^{2}=\zeta \frac{\rho_{S}^{2} A^{2} \varphi^{2}\left(S_{w f}-S_{w i}\right)^{2} r \gamma \cos \theta}{2 \mu} t
$$

čia $m$ - medžiagos masè kapiliarinio kilimo metu, g; $\varphi$ - medžiagos poringumas $\% ; \xi$ - vingiuotumo konstanta. Vietoj kapiliaro spindulio $r$ naujajame modelyje yra itraukiamas efektyvusis kapiliaro spindulys $r_{e}$, kuris yra lygus išbrinkusio kapiliaro kvadrato ir kapiliaro dalmeniui $r_{e}=\frac{r_{s}^{2}}{r}$. Todèl ị galutinę naujojo modelio formą itraukiamas kapiliaro efektyvusis spindulys, ir panašiai kaip kitame tyrime (Shi, Gardner, 2000), ì modeli ịtraukiamas tūrinis medžiagos brinkimas $\delta_{v}$ bei energijos paradimo koeficientas $C$. Naujasis modelis ịgauna tokią galutinę formą:

$$
m^{2}=\zeta \frac{\rho^{2} A^{2} \phi^{2}\left(S_{w f}-S_{w i}\right)^{2} r_{e} \gamma \cos \theta}{2 \mu} t-\frac{C \delta_{v}}{4 \mu \pi}\left(\frac{r_{s}}{r}\right)^{2} t .
$$

Apskaičiuotos medžiagos masės (g) kapiliarinio kilimo metu kiekvienu nagrinètu laiko momentu buvo perskaičiuojamos ị aukšti $(\mathrm{cm})$, todèl galutiniai modeliavimo rezultatai grafikuose, esančiuose rezultatų skyrelyje, pateikiami kaip kapiliarinio kilimo aukščio $(\mathrm{cm})$ priklausomybė nuo laiko $(t)$. Panašiai Markl et al. (2017) apibūdino efektyvuji spinduli, tačiau vietoj išbrinkusio spindulio buvo ịtraukiamas hidraulinis spindulys $\left(r_{e}=r_{h}^{2} / r\right)$. Šiame modelyje išbrinkęs spindulys $r_{s}$ apskaičiuojamas remiantis formule:

$$
r_{s}=\sqrt{\frac{\pi R^{2} \rho_{m}-\left(1+\delta_{v}\right) G_{m}}{\pi \rho_{m} R^{2}-G_{m}}} \cdot r
$$

čia $R$ - vamzdelio spindulys, m; $\rho_{m}$ - medžiagos tankis, $\mathrm{g} / \mathrm{cm}^{3} ; G_{m}-$ vamzdelio masè, g. Kapiliarinio kilimo biofiltre eksperimentui buvo pagaminti septyni skirtingi bioanglies $\left(450{ }^{\circ} \mathrm{C}, 2\right.$ val.) tipai: stambios $(900 \mu \mathrm{m}-1,6 \mathrm{~mm})$, vidutinès $(300-900 \mu \mathrm{m})$ ir smulkios $(<300 \mu \mathrm{m})$ frakcijų pušies medienos bioanglis, stambios frakcijos pušies žievès ir kanapių bioanglis, ramnolipidinio tirpalo $(40 \mathrm{mg} / \mathrm{l}, 3 \mathrm{val}$.) garais ir lietaus tirpalo garais (3 val.) modifikuota stambios frakcijos pušies medienos bioanglis. Bioanglis buvo gaminama mufelinejje krosnyje (E5CK-T), o bedeguonėms sąlygoms užtikrinti žaliava buvo sukama ị aliuminio foliją (Komkiene, Baltrenaite, 2016).

Kapiliarinio kilimo aukščiui ir laiko funkcijai modeliuoti, priklausomai nuo skysčių savybių, buvo pasirinkti keturi skirtingi lakieji organiniai (acetonas, 
toluenas, ksilenas ir heksanas) bei vienas lakusis neorganinis junginys (amoniakas) (2.1 lentelè). Skirtingi junginiai pasirinkti dèl jų skirtingo drèkumo remiantis Henrio konstantomis $\mathrm{K}_{\mathrm{H}}$. Kapiliariniam kilimui modeliuoti, priklausomai nuo skirtingos skysčių koncentracijos, buvo pasirinktas acetonas, kurio koncentracijos kito nuo 0,15 mol/l iki 1 mo/l (2.2 lentelè). Buvo tiriamos tokios bioanglies fizikinès savybès: poringumas $\varphi$, kontakto laipsnis $\theta$ ir vidutinis kapiliarų spindulys $r$ (2.3 lentelè).

2.1 lentelè. Modeliuotų skysčių fizikinès savybès

Table 2.1. Physical properties of modeled fluids

\begin{tabular}{|c|c|c|c|c|c|c|}
\hline \multirow[t]{2}{*}{ Tirpalas } & \multirow{2}{*}{ 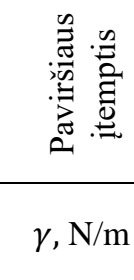 } & \multirow{2}{*}{ 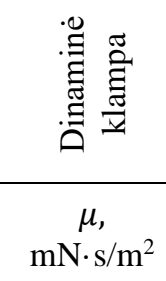 } & \multirow{2}{*}{ 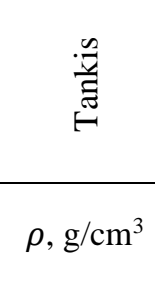 } & \multirow{2}{*}{ 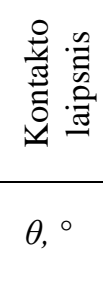 } & \multicolumn{2}{|c|}{ 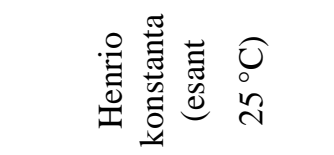 } \\
\hline & & & & & $\mathrm{K}_{\mathrm{H}}$ & Šaltinis \\
\hline Vanduo & 0,07 & 1 & 0,99 & 84 & - & - \\
\hline Acetonas & 0,03 & 0,32 & 0,78 & 26 & 0,00159 & Peng,Wan \\
\hline Toluenas & 0,03 & 0,55 & 0,87 & 33 & 0,235 & \\
\hline Ksilenas & 0,03 & 0,78 & 0,86 & 33 & 0,3 & \\
\hline Heksanas & 0,02 & 0,14 & 0,66 & 21 & 1,802 & \\
\hline Amoniakas & 0,08 & 0,13 & 0,61 & 87 & - & - \\
\hline
\end{tabular}

2.2 lentelė. Modeliuoto acetono tirpalų, priklausomai nuo skirtingos molinės koncentracijos tirpalo charakteristikos, naudotos modelyje, aplinkos temperatūros

Table 2.2. Characteristics of the modeled acetone solutions depending on the different molar concentration of the solution used in the model, at ambient temperature

\begin{tabular}{|l|l|l|l|l|}
\hline \multirow{2}{*}{$\begin{array}{c}\text { Acetono } \\
\text { koncentracija, } \\
\mathrm{mol} / \mathrm{l}\end{array}$} & $\begin{array}{c}\text { Paviršiaus } \\
\text { itemptis }\end{array}$ & $\begin{array}{c}\text { Dinamine } \\
\text { klampa }\end{array}$ & \multicolumn{1}{|c|}{ Tankis } & $\begin{array}{c}\text { Kontakto } \\
\text { laipsnis }\end{array}$ \\
\cline { 2 - 5 } & $\gamma, \mathrm{N} / \mathrm{m}$ & $\mu, \mathrm{mN} \cdot \mathrm{s} / \mathrm{m}^{2}$ & $\rho, \mathrm{g} / \mathrm{cm}^{3}$ & $\theta,{ }^{\circ}$ \\
\hline 0,6 & 0,02 & 0,32 & 0,78 & 26 \\
\hline 0,3 & 0,03 & 0,5 & 0,8 & 35 \\
\hline 0,15 & 0,04 & 1,1 & 0,82 & 45 \\
\hline
\end{tabular}




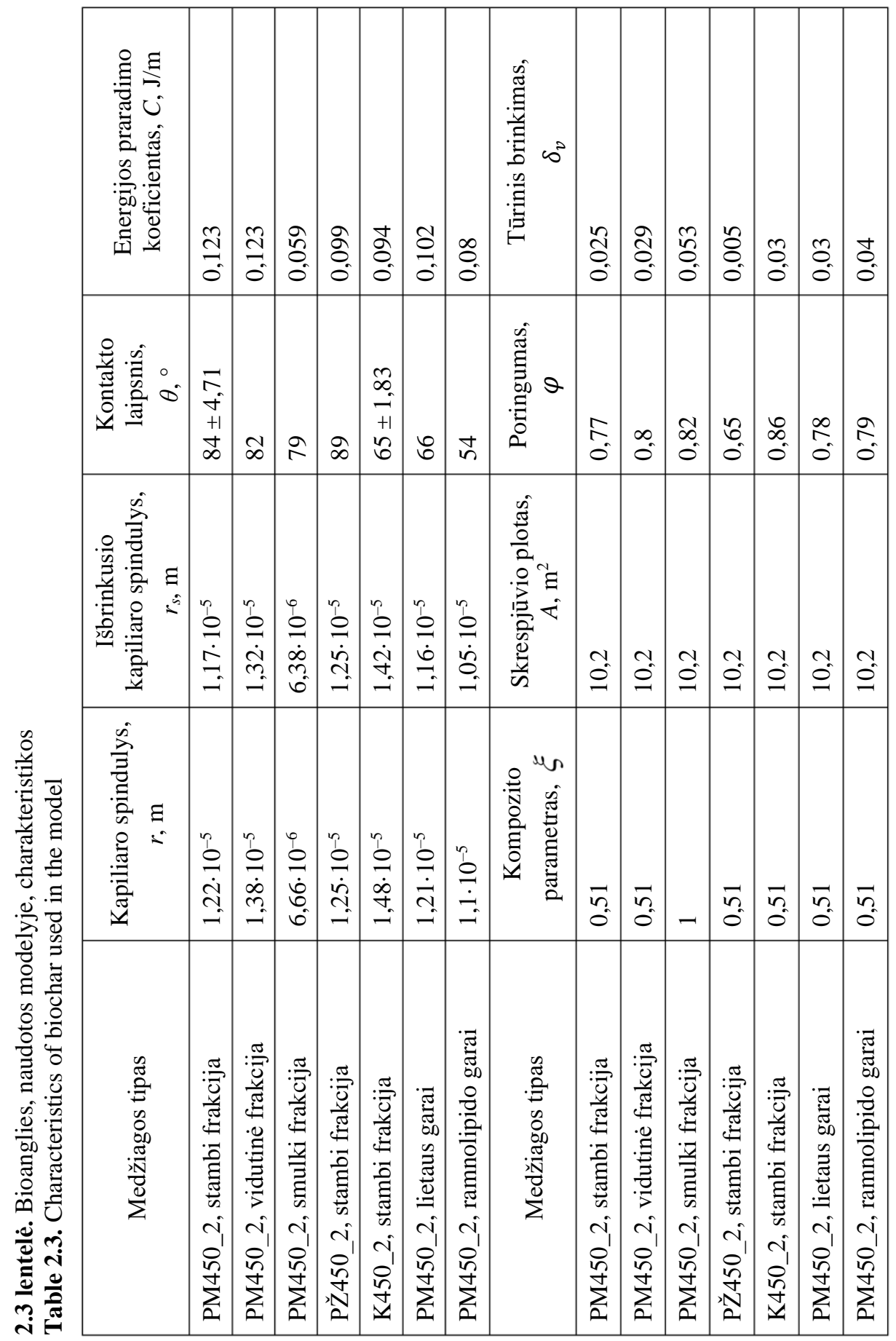


Poringumas medžiagoje nustatytas gyvsidabrio porozimetrijos metodu (Baltrėnas et al., 2015). Analizei naudotas gyvsidarbio intruzijos porozimetras „Quantachrome PoreMaster PM-33-12“. Kontakto laipsnis apibrěžiamas kaip laipsnis, kuriam esant skysčio paviršius liečia kietosios medžiagos paviršių Kontakto laipsnio verte šiame tyrime buvo įvertinta taikant sèslaus lašelio metodą. Buvo pritaikytas modifikuotas mėginio paruošimo metodas, kurị pasiūlè Shang et al. (2008). Bioanglies porų spindulys ịvertintas naudojantis SEM makrostruktūros nuotraukomis (SEM) (Giffin et al., 2013). SEM yra dažnas tiesioginis porų tipų atskyrimo metodas porų morfologijai nustatyti ir porų spinduliui apskaičiuoti. Naudota „ImageJ“ programa porų spinduliui įvertinti remiantis 2D nuotraukomis. Nuotraukų apdorojimo technologijos taip pat, kaip ir duomenų generavimas, teikia tikslius duomenis. Nuotraukų apdorojimo sistema puikiai tinka bioanglies porų dydžiui ịvertinti.

- Bioanglies tūrinis brinkimas

Bioanglies tūrinis brinkimas ịvertintas vamzdelyje, praejus 24 val. po vandens kapiliarinio kilimo. Bioanglies tūrio padidejjimas išreiškiamas brinkimo santykiu (Sienkiewicz et al., 2017):

$$
S=\frac{V_{s}-V_{d}}{V_{d}} \cdot 100 \%,
$$

čia $S$ - medžiagos tūrio padidèjimas, $\% ; V_{s}$ - išbrinkusios medžiagos tūris, $\mathrm{cm}^{3}$; $V_{d}$ - sausos medžiagos tūris, $\mathrm{cm}^{3}$.

- Skysčio dinaminè klampa

Skysčio absoliučiajai (dinaminei) klampai įvertinti naudojamas Ostwaldo viskometras (Okechukwu, 2019). Skysčio dinaminei klampai apskaičiuoti naudojama ši formulè:

$$
\frac{\mu_{1}}{\mu_{2}}=\frac{t_{1} \rho_{1}}{t_{2} \rho_{2}}
$$

čia $\mu_{1}$ - pirmo nagrinèjamo skysčio klampa, poise; $\mu_{2}$ - vandens klampa, lygi 0,89 poise; $t_{1}$ - pirmojo skysčio tekejjimo laikas; $t_{2}$ - vandens tekejjimo laikas; $\rho_{1}-$ pirmojo skysčio tankis; $\rho_{2}$ - vandens tankis, kuris yra lygus $0,99 \mathrm{~g} / \mathrm{cm}^{3}$.

- Skysčio paviršiaus įtemptis

Skysčio paviršiaus įtemptis ịvertinta remiantis nagrinejjamo skysčio pakilimo siaurame vamzdelyje aukščiu ir tankiu. Skysčio paviršiaus itemptis apskaičiuojama remiantis formule (Vinš et al., 2013):

$$
\gamma=\frac{\rho h g R}{2} \text {. }
$$

Skysčio paviršiaus ịtempčiai įvertinti vonelè su nežinomos įtempties skysčiu užpildoma iki 2,54 cm aukščio. I skystị panardinamas skaidrus ir siauras vamzdelis, kuriame išmatuojamas skysčio pakilimo aukštis (m). Kapiliarinio 
vamzdelio skersmuo išmatuojamas liniuote, kuris vẻliau padalijamas iš dviejų, kad būtų gautas vamzdelio spindulys.

- Skysčio tankis

Skysčio tankis apskaičiuotas remiantis lygtimi:

$$
\rho=\frac{m}{v}
$$

čia $\rho$ - skysčio tankis, $\mathrm{kg} / \mathrm{m}^{3} ; m$ - tam tikro tūrio $(50 \mathrm{ml})$ skysčio svoris, $\mathrm{kg} ; v$ skysčio tūris $(50 \mathrm{ml})$.

Kapiliarinio kilimo greičiui ịvertinti bioanglies bioịkrovoje buvo naudotas biofiltras su kapiliarinio drékinimo sistema (2.3 pav.). Tiriant bioịkrovų kapiliarumą, apatinė biofiltro dalis buvo užpildoma vandeniu, $\mathfrak{i}$ kurị buvo įmerkti iki $7,5 \mathrm{~cm}$ gylio septyni organinio stiklo perforuoti $30 \mathrm{~cm}$ ilgio ir $1,8 \mathrm{~cm}$ vidinio skersmens vamzdeliai su skirtingomis bioanglies bioịkrovomis. Vamzdelio apačioje buvo ịtvirtinti smulkūs geležiniai tinkleliai, kurie neleido kietosios medžiagos dalelėms patekti ị vandenị (Wangler, Kohlus, 2017). Prie vieno vamzdelio šono buvo pritvirtinta metalinè graduota liniuotè. Bioịkrovos drègnoji ir sausoji zonos vizualiai skyrèsi ir buvo fiksuojamas medžiagos sudrèkimo aukštis priklausomi nuo laiko (Tsunazawa et al., 2016). Biofiltro stendo schema kapiliariniam kilimui ịvertinti pateikta 2.2 paveiksle.

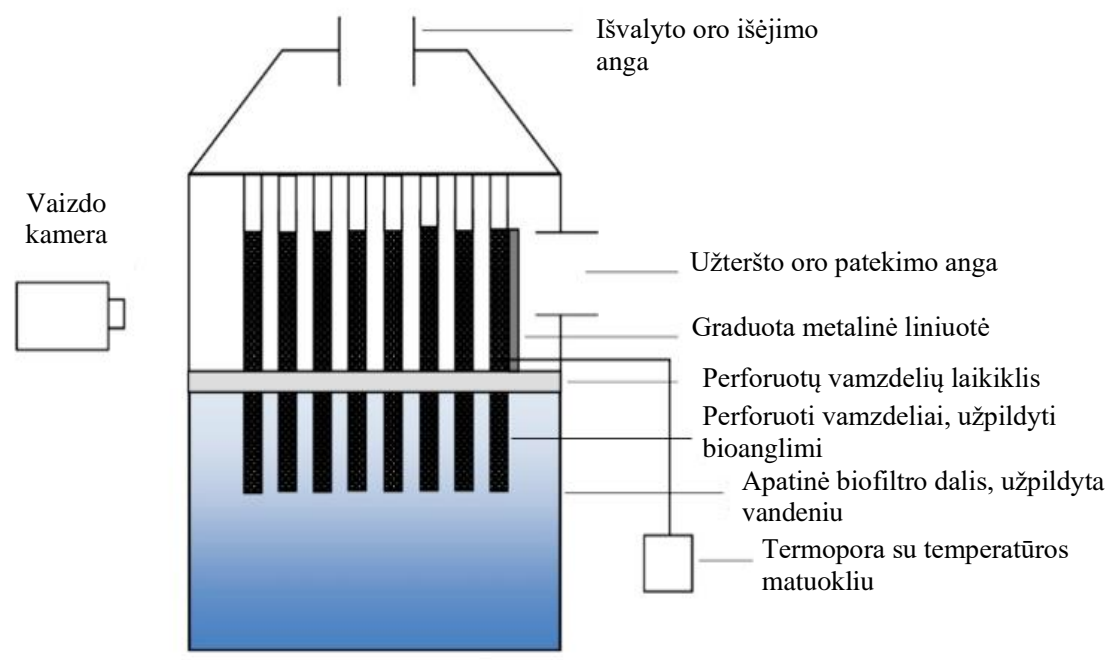

2.2 pav. Kapiliarinio kilimo ịvertinimo bioanglies bioịkrovoje, esančioje biofiltre, schema (autorès paveikslas)

Fig. 2.2. Scheme of capillary rise in the biocharge of biochar in biofilter (author's figure) 


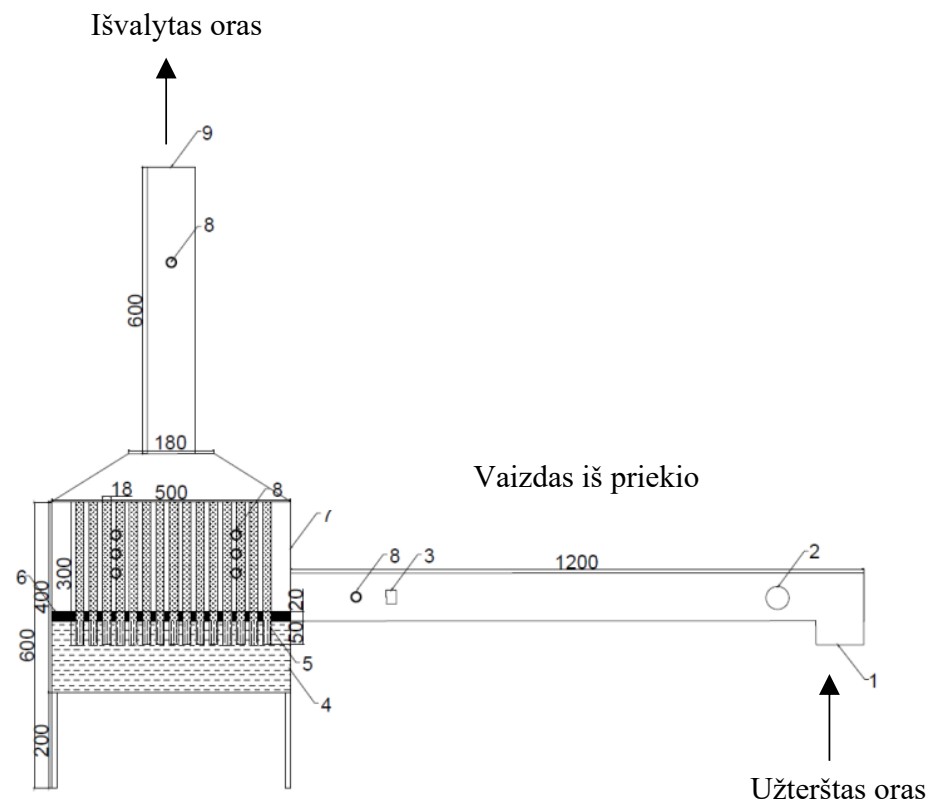

2.3 pav. Biofiltro inžinerinis brèžinys: 1 - lakiụjų junginių garų ịvedimo anga; 2 - ívedimo angos uždarymo sklendè; 3 - temperatūros reguliatorius; 4 - talpykla, užpildyta vandeniu; 5 - kapiliarinis vamzdelis; 6 - laikiklis; 7 - talpykla, užpildyta lakiųju junginių garais; 8 - lakiujų junginių koncentracijos garuose, oro temperatūros ir drègnio pamatavimo angos; 9 - garų išmetimo vamzdis (autorès paveikslas)

Fig. 2.3. Biofilter engineering drawing: 1 - vapor inlet for volatile compounds; 2 - inlet closing valve; 3 - temperature regulator; 4 - tank filled with water; 5 - capillary tube;

6 - holder; 7 - container filled with volatile compounds; 8 - measuring holes for concentrations of volatile compounds in the steam, air temperature, and humidity; 9 - residual exhaust pipe (author's figure)

Dèl temperatūros pakilimo matavimo kapiliarinio kilimo metu, $\mathrm{K}$ tipo termopora (TM902C temperatūros matuoklis su K tipo termopora) įstatyta ị vamzdelio skylę ( $2 \mathrm{~cm}$ aukštyje nuo laikiklio pradžios). Energija vamzdelyje prarandama $(\mathrm{J} / \mathrm{m})$, nes skysčių skverbimasis ị mikroporas lemia brinkimo šilumos susidarymą, kuri išsiskiria iš kapiliarinès sistemos (Shi, Gardner, 2000). Temperatūros pakilimo fenomenas rodo, kad kapiliarinio kilimo metu vyksta dalelių brinkimas medžiagos ir vandens sistemoje. Kai temperatūra nebekyla prabėgus tam tikram laikui, galima teigti, kad brinkimas sustoja.

Aprašomoji statistika (vidurkis, standartinis nuokrypis, maksimumas, minimumas) buvo atlikta naudojantis Microsoft Excel 2016 programa. Teorinis kapiliarinio kilimo aukščio $h$ priklausomybès nuo laiko $t$ įvertinimas atliktas naudojantis Microsoft Excel 2016 programa. 


\subsection{Bioanglies drèkumo ryšio su jos fizikinėmis ir cheminèmis savybèmis nustatymas}

Tyrimų tikslas - eksperimentiškai ịvertinti pirolizès sąlygų (temperatūros, kaitinimo laiko) ir lignoceliuliozinès žaliavos ịtaką bioanglies cheminèms savybèms $(\mathrm{pH}$, peleningumas, elementinè sudètis, paviršiaus funkcinès grupès, ištirpusi organinė, neorganinė anglis ir ištirpęs azotas, elektrinis laidis, drèkumas) bei fizikinèms savybėms (vandens laikomoji geba, tankis, savitasis paviršiaus plotas, porų tūris ir dydis, struktūra). Lignoceliuliozinė žaliava bioanglies gamybai pasirinkta dẻl jos atliekų gausos bei ir aspektų (atsinaujinanti žaliava). Naudojantis daugialype regresine analize nustatyta, kokiomis kitomis bioanglies savybėmis galima prognozuoti jos drékumą ir vandens laikomają gebą.

Bioanglis buvo gaminama iš penkių lignoceliuliozinių žaliavų: paprastosios pušies (Pinus sylvestris) medienos, pušies žievès, karpotojo beržo (Betula pendula) medienos, beržo žievès ir pluoštinių kanapių (Cannabis) (2.4 pav.). Kanapių atmaina - „Futura 75“, aukštos kokybès prancūzų pramoninė kanapių rūšis. Pušies mediena ir beržo mediena buvo surinkta iš Dūkštų-Šilènų miško, esančio pietryčių Lietuvoje, o pušies ir beržo žievė - iš Gaidès miško, esančio šiaurès rytų Lietuvoje. Kanapių mėginiai buvo surinkti iš Panevėžio rajono savivaldybès teritorijos.

a)

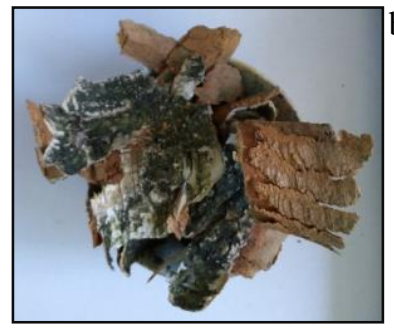

d)

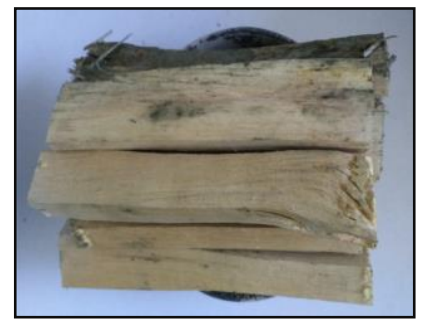

b)

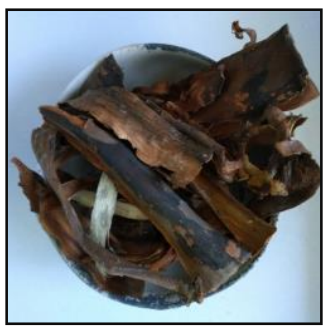

e)
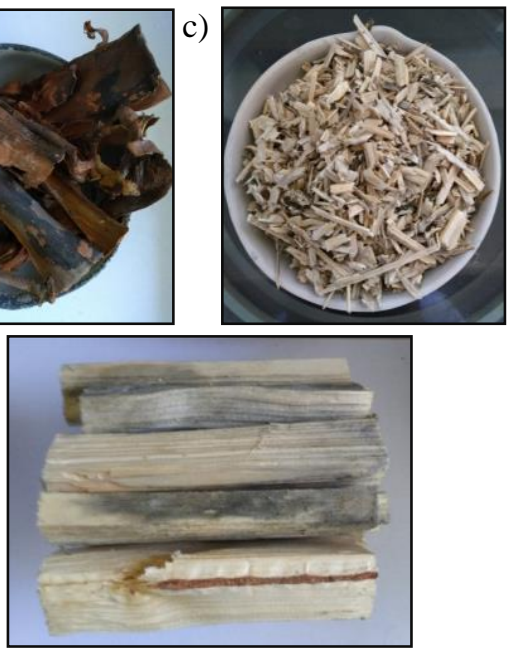

2.4 pav. Lignoceliuliozinès žaliavos bioanglies gamybai: a) beržo žievė; b) pušies žievė; c) kanapès; d) beržo mediena; e) pušies mediena (autorès nuotraukos)

Fig. 2.4. Lignocellulosic feedstocks for biochar production: a) birch bark; b) pine bark; c) hemp; d) birch wood; e) pine wood (author's photos) 
Bioanglis - produktas, gaminamas iš tvarios biomasès (augalų organinès medžiagos) termocheminès konversijos būdu (pirolizès), kuri naudojama žemès ūkyje ir gali būti naudojama kaip žaliava pramoniniams procesams (Hagemann et al., 2018). Lignoceliuliozinè biomase puikiai tinka bioanglies gamybai, nes ji pasižymi mažu peleningumu, dideliu lignino kiekiu ir išlaiko originalią biomasès porų struktūrą.

Vertinant pirolizès laiko įtaką bioanglies fizikinėms ir cheminėms savybėms, žaliavos buvo kaitinamos mufelinejje krosnyje (SNOL, E5CK-T) dviejose temperatūrose $\left(450\right.$ ir $700{ }^{\circ} \mathrm{C}$ ), dviem kaitinimo laikams (1 ir 2 val.) bei apytiksliai $10^{\circ} \mathrm{C} / \mathrm{min}$ kaitinimo greičiui. Vertinant temperatūros poveikị bioanglies fizikinèms ir cheminėms savybèms, bioanglis buvo gaminama devyniose temperatūrose $\left(300,350,400,450,500,550,600,650,700{ }^{\circ} \mathrm{C}\right)$ ir 2 val. kaitinimo laiko. Žaliavų mėginių svoriai siekè apie $200 \mathrm{~g}$, kurie buvo vėliau sukami ị aliuminio foliją dèl deguonies stygiaus sąlygų sukūrimo (Baltrènaitė et al., 2017). Po pirolizès buvo nustatomos bioanglies fizikinès ir cheminès savybès. Prieš kiekvieną analizę mėginiai buvo sumalami dèl jų homogenizavimo.

Bioanglies išeiga išreiškiama sausaja masès procentine dalimi (Naeem et al., 2014):

$$
I_{\text {bioanglies }}=\frac{M_{\text {bioanglies }}}{M_{\check{z} \text { aliavos }}} \cdot 100 \%,
$$

čia $I_{\text {bioanglies }}$ - ore išdžiovintos bioanglies išeiga, \%; $M_{\text {bioanglies }}-$ bioanglies svoris po pirolizès, kg; $M_{\check{z} \text { aliavos }}$ išdžiovintos žaliavos svoris, $\mathrm{kg}$.

Piltiniam tankiui nustatyti stiklinis cilindras $(10 \mathrm{ml})$ pripildomas smulkintos bioanglies ir džiovinama džiovinimo spintoje $80^{\circ} \mathrm{C}$ temperatūroje 8 val. (EBC, 2012). Paskui cilindras kratomas 1 minutę bioangliai suslègti ir tankis apskaičiuotas remiantis formule (Mary et al., 2016):

$$
B D_{d}=\frac{m_{d}}{V_{d}}
$$

čia $B D_{d}$ - sauso mėginio piltinis tankis, $\mathrm{g} / \mathrm{cm}^{3} ; m_{d}$ - sauso mėginio masè, $\mathrm{g} ; V_{d}-$ sauso mèginio tūris, $\mathrm{cm}^{3}$.

Bioanglies peleningumui nustatyti tiglis su mèginiu pasvertas ir idètas $i$ krosnic. 1 valandą mėginys kaitinamas $550{ }^{\circ} \mathrm{C}$ temperatūroje mufelinèje krosnyje (SNOL2000/2002). Po kaitinimo likusi masė buvo išreikšta kaip pelenų masė (Sun et al., 2017). Remiantis svorių rezultatais, pelenų kiekis apskaičiuotas remiantis formule:

$$
\text { Peleningumas }=\frac{M_{2}-M_{c}}{M_{1}-M_{c}} \times 100 \%,
$$

čia $M_{c}$ - tuščio tiglio masè, $\mathrm{g} ; M_{1}$ - tiglio su mėginiu masè prieš kaitinant, $\mathrm{g} ; M_{2}-$ tiglio su pelenais masè po kaitinimo, $\mathrm{g}$. 
Bioanglies $\mathrm{pH}$ nustatyti $5 \mathrm{ml}$ ore išdžiovinto mėginio buvo ịdèta ị stiklinị indą (EBC, 2012). Paskui ịpilta $25 \mathrm{ml} 0,01 \mathrm{M} \mathrm{CaCl}_{2}$ tirpalo. Suspensija buvo kratoma 1 valandą kratytuvu („Rotoshake RS12“, Gerhardt $\mathrm{GmbH}$ ). pH tiesiogiai ivertintas suspensijoje naudojantis pH matuokliu „Mettler Toledo Seven Multi“.

Elektriniam laidžiui nustatyti $10 \mathrm{~g}$ méginio buvo įdèta ị $100 \mathrm{ml}$ nudruskintą vandenị ir kratoma 1 valandą (EBC, 2012). Paskui tirpalas filtruotas pro filtravimo popierių (VWR 413, daleliu sulaikymas $5 / 13 \mu \mathrm{m}$ ). Elektrinis laidis ịvertintas filtravimo vandenyje, naudojantis „InoLab WTW“ serijos 740 elektrinio laidžio matuokliu.

Elementinè sudètis $(\mathrm{C}, \mathrm{H}, \mathrm{N}, \mathrm{O})$ buvo nustatyta naudojantis „EuroEA3000Single“ analizatoriumi (EBC 2012). 1,5 mg išdžiovinto ir susmulkinto mėginio buvo pasverta tiesiogiai mažoje kapsulëje ( $0,1 \%$ tikslumu), kuri véliau ịdèta ị analizatorių. EA3000 analizatoriai remiasi dinaminiu greitojo degimo principu, po kurio vyksta dujų $\left(\mathrm{N}_{2}, \mathrm{CO}_{2}, \mathrm{H}_{2} \mathrm{O}, \mathrm{SO}_{2}\right)$ chromatografinis atskyrimas.

Vandens sulaikymui nustatyti $10 \mathrm{~g}$ méginio buvo mirkoma vandenyje $24 \mathrm{val}$. ir įdedama ị filtrą 2 valandoms dèl perteklinio vandens pašalinimo ( $\mathrm{Yu}$ et al., 2013). Prisotinta medžiaga buvo pasverta ir džiovinta $40{ }^{\circ} \mathrm{C}$ džiovinimo krosnyje. Po džiovinimo medžiaga buvo iš naujo pasverta vandens laikomajai gebai ivertinti. Vandens laikomoji geba apskaičiuota remiantis šia formule:

$$
V S G=\frac{M_{2}-M_{3}}{M_{2}-M_{1}} \times 100 \%,
$$

čia $M_{3}$ - išdžiovintos bioanglies masè po jos prisotinimo vandenyje, $\mathrm{g} ; M_{2}-$ drègnos bioanglies masè, g; $M_{1}$ - talpyklos, kurioje laikoma drèkinama bioanglis, masè, g.

Morfologinè analizė buvo atlikta naudojantis skenuojančiąja elektronų mikroskopija (SEM) (Baltrènas et al., 2016). Prieš analizę mėginiai buvo džiovinami $105^{\circ} \mathrm{C}$ temperatūroje 24 val., paskui paskirstyti (apytiksliai vienas šaukštas mejginio) ant Petri lëkštelès. SEM analizè buvo atlikta naudojantis mikroskopu SIGMA HD/VP. Siekiant geriau atvaizduoti mėginio paviršiaus charakteristikas, buvo didinama ịvairiais masteliais.

Savitajam paviršiaus plotui (SPP) apskaičiuoti buvo taikyta $\mathrm{N}_{2}$-Brunauer, Emmett ir Teller (BET) teorija (Baltrènas et al., 2016). BET analizė atlikta naudojantis Nova 4200 E serijos analizatoriumi („Quantachrome Instruments“). Porų tūris apskaičiuojamas remiantis $t$ teorija, o porų dydžio pasiskirstymas apskaičiuojamas remiantis Barrett, Johner ir Halendar (BJH) teorija.

Funkcinès grupès buvo įvertintos Fourier pernešimo infraraudonujų spindulių spektroskopija (FTIR) esant bangu skaičiui nuo 450 iki $4000 \mathrm{~cm}^{-1}$ (Huang et al., 2017). Oksidacinių funkcinių grupių nustatymas bioanglyje svarbus tuo, kad nuo jų skaičiaus priklauso bioanglies drèkumo lygis. 
Ištirpusiai bendrajai angliai (IBA), ištirpusiai neorganinei angliai (INA) ir ištirpusiai organinei angliai (IOA) įvertinti 2,5 g méginio buvo maišoma su $25 \mathrm{ml}$ $0,5 \mathrm{M} \mathrm{K}_{2} \mathrm{SO}_{4}$ tirpalu ir kratoma 1 val. Tirpalas buvo skiedžiamas su $20 \mathrm{ml}$ distiliuoto vandens. Tirpalas prafiltruotas per filtravimo popieriu (VWR 413, dalelių sulaikymas $5 / 13 \mu \mathrm{m})$ ir analizuotas naudojantis „Shimadzu TOC-V 5000A“" analizatoriumi (Baltrènaitè et al., 2017).

Ryšiui tarp bioanglies drékumo ir vandens laikomosios gebos bei kitų jos fizikinių ir cheminių savybių atskleisti, naudojantis daugialype linijine regresine analize, buvo gautos lygtys. Buvo gauti du modeliai, iš kurių pirmajame priklausomasis kintamasis buvo bioanglies vandens laikomoji geba, o nepriklausomieji kintamieji - kitos jos fizikinès ir cheminès savybès, o antrajame modelyje - priklausomasis kintamasis buvo bioanglies drèkumas. Ryšys tarp savybių buvo ịvertintas naudojantis „Origin 2018b“ programa. Daugialypė regresinè analizė yra paprastos linijinès regresinès analizės plètinys ir, naudojantis regresijos lygtimi, galima prognozuoti priklausomojo kintamojo reikšmes pagal nepriklausomųjų kintamųjų reikšmes.

\subsection{Bioanglies drèkumo įvertinimas vandens lašelio skverbimosi laiko testu, molingumo testu ir kontakto laipsnio analize}

Tyrimo tikslas - skirtingais medžiagos drëkumo ịvertinimo metodais (vandens lašelio skverbimosi laiko testu, molingumo testu ir kontakto analize) nustatyti besiskiriančių bioanglies tipų drėkumą bei, remiantis Pirsono koreliacine analize, nustatyti linijinę drékumo rezultatų koreliaciją. Pateikti teoriniai ir eksperimentiniai skirtingų metodų tikslumo ir tinkamumo bioanglies požiūriu pagrindimai.

VLSL testo procedūrą sudaro vandens lašelio nuleidimas ant tiriamosios medžiagos paviršiaus ir laiko, skirto visiškam prasiskverbimui, ịvertinimas. Naudoti $5 \mathrm{~g}$ homogenizuoti bioanglies méginiai, kurie buvo įdèti ì $12 \mathrm{ml}$ tūrio buteliukus. Pipete trys vandens lašeliai buvo lašinami ant paviršiaus iš $<10 \mathrm{~mm}$ aukščio siekiant išlaikyti pastovų lašelio tūrị. Laikmačiu buvo vertinta, kiek vandens lašeliui užtrunka prasiskverbti pro mėginį (Kinney et al., 2012). Trumpiausias laikas $(\leq 1 \mathrm{~s})$ atitinka momentini prasiskverbimą ir tokia medžiaga laikoma hidrofiliška. Drèkumo kategorijos su atitinkamais VLSL pateiktos 1.3 poskyryje.

ELM testo metu buvo naudojami septynių koncentracijų etanolio tirpalai ( 0 , $3,5,11,13,18,24$ ir $36 \%$ ) ir buvo vertinama jų sorbcija ant bioanglies paviršiaus per 3 s. Paruoštų tirpalų lašeliai $(0,05 \mathrm{ml})$ pipete buvo lašinami ant išlyginto 
bioanglies paviršiaus iš $<5 \mathrm{~mm}$. Tirpalo lašelis buvo lašinamas iš nedidelio aukščio tam, kad būtų galima išvengti kinetinès energijos pertekliaus, galinčio suardyti bioanglies paviršių (Page-Dumroese et al., 2015). Drèkumo indeksai su atitinkamomis etanolio tirpalų koncentracijomis pateikti 1.3 poskyryje. ELM vertès kategorizuojamos nuo 1 (labai hidrofiliškas) iki 7 (ypač hidrofobiškas), kai $0 \%$ etanolio vertė atitinka labai hidrofilišką medžiaga, o $36 \%$ vertė - ypač hidrofobišką.

Nejudančio lašelio metodu išmatuojamas vandens lašelio, esančio ant bioanglies paviršiaus, kontakto laipsnis. Kontakto laipsnis gali būti apibrèžtas kaip tangentinis laipsnis tarp skysčio, kontaktuojančio su bioanglies paviršiumi, periferinio taško ir bioanglies paviršiaus, ant kurio yra lašelis (2.5 pav.) (Biria et al., 2013). Kontakto laipsniui matuoti pipete iš lèto $\sim 5 \mathrm{~s}$ iš $\sim 1 \mathrm{~cm}$ aukščio nuo $600 \mu \mathrm{m}$ dydžio bioanglies paviršiaus buvo išspaustas $0,5 \mathrm{ml}$ dejonizuoto vandens lašelis. Buvo padaryta vandens lašelio profilio nuotrauka „Alcatel Idol-4“ kamera, fotografuojant $10 \mathrm{~cm}$ atstumu nuo mėginio. Nuotraukos buvo verčiamos i pilkos spalvos skalę naudojantis „PhotoScape“ ir apkarpytos. Nuotraukos (2.5 pav.) analizuotos naudojantis „ImageJ“" su „DropSnake“ lašelio analizès papildiniu (Jeffery et al., 2015).

a)

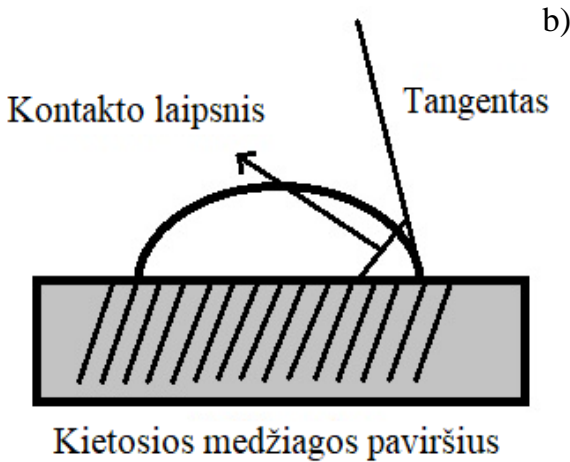

b)

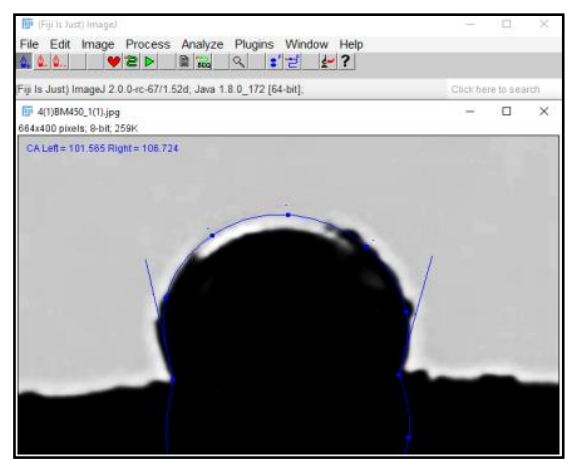

2.5 pav. Vandens lašelio, nuleisto ant kietosios medžiagos paviršiaus, vaizdas: a) scheminis vaizdas; b) „DropSnake“ papildinys „ImageJ“ programoje (autorès paveikslai)

Fig. 2.5. Image of water droplet lowered on the solid surface: a) schematic picture; b) DropSnake plugin in ImageJ (author's figures)

Statistiniai parametrai (vidurkiai, standartiniai nuokrypiai, Pirsono koreliacijos koeficientai) buvo apskaičiuoti ir skirtingų metodų drèkumo duomenys palyginti naudojantis „Statistica10“ programiniu paketu. Pirsono koreliacija buvo 
atlikta siekiant nustatyti potencialų ryšių tarp bioanglies drèkumo, įvertinto skirtingais metodais (VLSL testu, ELM testu ir kontakto laipsnio analize).

\subsection{Bioanglies modifikacija fizikiniais ir cheminiais metodais}

Tyrimo tikslas - modifikuoti žematemperatūrę $\left(450^{\circ} \mathrm{C}\right)$ beržo žievès bioangli, remiantis skirtingais fizikiniais ir cheminiais metodais, siekiant padidinti bioanglies drèkumą. Bioanglies hidrofiliškumas yra naudingas naudojant ją ivairiais atvejais, ypač biofiltruose hidrofiliniams teršalams šalinti iš oro. Fizikinei bioanglies modifikacijai ji buvo veikiama mechaniniu būdu (smulkinant) bei aktyvinama skirtingų tirpalų (lietaus vandens, ramnolipidinio tirpalo) garais jos mikroporingumui ir iš dalies deguonies turinčių funkcinių grupių kiekiui padidinti. Cheminei bioanglies modifikacijai buvo naudojama azoto rūgštis, siekiant sukurti deguonies ir azoto turinčias funkcines grupes, kurios yra svarbios teršalų adsorbcijai.

Bioanglis tyrimui buvo gaminta iš beržo žievès bedeguonėmis sąlygomis $450{ }^{\circ} \mathrm{C}$ temperatūroje ir 2 val. kaitinant laiko vamzdinèje krosnyje (SNOL 0,7/1250). Ši krosnis sukuria visiškai inertinę atmosferą leidžiant azoto dujas, dèl to galima gauti visiškai karbonizuotą produktą. Gauta bioanglis buvo smulkinama ir frakcionuojama sijojimo būdu (,Retsch“, 1,6 mm, $900 \mu \mathrm{m}$ ir $300 \mu \mathrm{m}$ dydžių sietai). Bioanglies frakcijos pasirinktos remiantis kitu tyrimu (Liu et al., 2017), kuriame smulki frakcija vadinama $<0,25 \mathrm{~mm}$ dydžio, vidutinè $-0,25-0,85 \mathrm{~mm}$ dydžio, o stambi - 0,85-2 mm dydžio. Gautų frakcijų (stambios - $900 \mu \mathrm{m}-$ $1,6 \mathrm{~m}$, vidutinès $-300-900 \mu \mathrm{m}$ ir smulkios $-<300 \mu \mathrm{m}$ ) bioanglis toliau buvo tiriama norint nustatyti drèkumą vandens lašelio skverbimosi laiko testu (Leelamanie et al., 2008).

Lietaus vanduo bioanglies modifikacijai buvo renkamas Aukštaitijos kompleksiško monitoringo stotyje, esančioje Rūgšteliškio kaime, Utenos rajone. Jis buvo renkamas plastikiniu 51 talpos vandens surinktuvu, kuris buvo paliekamas atviroje erdveje mėnesiui ir vanduo buvo renkamas kiekvieną kartą po lietingos dienos. Jis buvo ịrengtas netrikdomoje natūralios vegetacijos žemëje. Lietaus vanduo buvo surenkamas ir laikomas gerai užsandarintuose didelio tankio polietileno (HDPE) surinkimo buteliuose, tamsoje, kambario temperatūros patalpoje. Buvo vertinta surinkto vandens $\mathrm{pH}$ verte ir elektrinis laidis. Lietaus vandens $\mathrm{pH}$ buvo vertinamas naudojantis $\mathrm{pH}$ matuokliu (,Mettler MultiSeven“), o elektrinis laidis - naudojantis konduktometru („WTW inoLab terminal 740“).

Bioanglis buvo modifikuota tirpalų garais bioanglies hidrofiliškumo didinimo įrenginyje (Baltrenas et al., 2019). Buvo pasirinkti trijų tirpalų garai: dejonizuoto vandens, lietaus vandens ir ramnolipidinio tirpalo $(5,20,40 \mathrm{mg} / \mathrm{l})$. 
Bioanglies modifikacija ramnolipidinio tirpalo garais grindžiama dervomis užsikimšusių porų išvalymu, paviršiaus oksidacija ir ramnolipidinių molekulių įterpimu ị bioanglies poras, dèl to pagerejja organinių teršalų išvalymas iš oro.

Norint sukurti paviršiaus deguonies ir azotą turinčias grupes, bioanglis buvo oksiduojama skirtingų koncentracijų $\mathrm{HNO}_{3}$ tirpalais. $1,0 \mathrm{~g}$ išdžiovintų bioanglies miltelių buvo paveikta $25 \mathrm{ml} 20 \%, 40 \%$ ir $65 \% \mathrm{HNO}_{3}$ tirpalais $80{ }^{\circ} \mathrm{C}$ temperatūroje (esant nuolatiniam maišymui). Po poveikio bioanglis atidžiai praplauta dejonizuotu vandeniu ir džiovinta $105^{\circ} \mathrm{C}$ temperatūroje (Guzel et al., 2017).

\subsection{Bioanglies naudojimas biofitracijos procese lakiesiems teršalams iš oro šalinti}

Šis tyrimas vertino ramnolipidinio tirpalo garais modifikuotos pušies medienos bioanglies efektyvumą šalinti lakiuosius organinius (acetoną, ksileną) ir neorganinius (amoniaką) junginius. Kadangi garais modifikuota bioanglis yra drèkesnè, mikroporingesnè ir turi didesni paviršiaus plotą, tikètina, kad tokia bioanglis bus efektyvesnè hidrofiliniams junginiams iš oro šalinti. Tikslas nustatyti biofiltro su kapiliarine drèkinimo sistema efektyvumą lakiesiems junginiams pašalinti iš oro. Remiantis Henrio konstantomis, buvo ịvertintas skirtingo drèkumo junginiu biologinis skaidymas (nuo hidrofilinio acetono ir amoniako iki vidutiniškai hidrofobinio ksileno) (2.4 lentelè).

Biofiltras buvo sudarytas iš dviejų ièjimo ir išejimo vamzdžių bei rezervuaro, kuriame buvo įdèti 86 organinio stiklo vamzdeliai, užpildyti medienos bioanglies ir plaušo bioịkrova. Bendras kiekvieno biofiltro vamzdelio aukštis siekè $0,3 \mathrm{~m}$, o vidinis skersmuo - 0,02 m. Pirmajame eksperimente vamzdeliai buvo pildomi nemodifikuota pušies medienos bioanglies $\left(450{ }^{\circ} \mathrm{C}, 2\right.$ val.) ir beržo plaušo mišiniu santykiu 10:1, o antrajame - to paties santykio ramnolipidinio tirpalo garais modifikuota pušies medienos bioanglies ir plaušo mišinio bioịkrova. Bioanglis buvo gaminama mufelinejje krosnyje (E5CK-T) (Baltrènaitė et al., 2017). Beržo skaidulos buvo gautos terminiu beržo pjuvenų apdorojimo metu garų reaktoriuje esant 32 barų slègiui ir $235^{\circ} \mathrm{C}$ temperatūrai (Baltrènas, Mačaitis, 2014). Bioanglies modifikacijai buvo naudojamas bioanglies hidrofiliškumo didinimo ịrenginys (Baltrènas et al., 2019). Užterštas oro srautas buvo sukuriamas maišant koncentruotus lakiujų junginių tirpalus su dejonizuotu vandeniu santykiu 1:10. Oro srauto greitis biofiltre buvo kontroliuojamas naudojant įvesties vamzdžio sklendę. Skirtingos acetono, ksileno ir amoniako garu koncentracijos buvo leidžiamos per bioịkrovą dèl mikroorganizmų aktyvumo išlaikymo. Šis laiko tarpas vadinamas mikroorganizmų aktyvavimo laiku (Baltrėnas et al., 2015). Biofiltro veikimo pradžioje teršalų koncentracija garuose, perejjusiuose pro 
bioịkrovą, siekè apie $20 \mathrm{mg} / \mathrm{m}^{3}$. Teršalai buvo tiekiami ị ịrenginị keturis kartus per dieną po $15 \mathrm{~min}$. Vèliau jie buvo tiekiami kas dvi dienas ilginant teršalo tiekimo laiką iki 1 val. Bioịkrova buvo aktyvinama 2 savaites, po kurių stebėtas biofiltro oro valymo efektyvumas.

2.4 lentelè. Acetono, ksileno ir amoniako fizikinès ir cheminès savybès, ND - nèra duomenu (National Research Council, 2010; Bruneel et al., 2018)

Table 2.4. Physico-chemical properties of acetone, xylene, and ammonia, ND - no data available (National Research Council, 2010; Bruneel et al., 2018)

\begin{tabular}{|c|c|c|c|c|}
\hline Parametras & Vienetas & Acetonas & Ksilenas & Amoniakas \\
\hline Cheminè formulè & - & $\mathrm{C}_{3} \mathrm{H}_{6} \mathrm{O}$ & $\mathrm{C}_{8} \mathrm{H}_{10}$ & $\mathrm{NH}_{3}$ \\
\hline Molekulinè masè & $\mathrm{g} / \mathrm{mol}$ & 58,1 & 106 & 17 \\
\hline Kvapų ribinè vertè & ppmv & 100 & 1 & 46,8 \\
\hline Virimo taškas & ${ }^{\circ} \mathrm{C}$ & 56,2 & $137-140$ & $-33,3$ \\
\hline $\begin{array}{l}\text { Garų slègis (esant } \\
20^{\circ} \mathrm{C} \text { ) }\end{array}$ & $\mathrm{mmHg}$ & 182 & 6,72 & 6661 \\
\hline $\mathrm{pH}$ & $\mathrm{pH}$ vienetai & 7 & ND & 11,6 \\
\hline Tankis & $\mathrm{g} / \mathrm{cm}^{3}$ & 0,78 & 0,86 & 0,68 \\
\hline $\begin{array}{l}\text { Tirpumas } \\
\text { vandenyje (esant } \\
25^{\circ} \mathrm{C} \text { ) }\end{array}$ & $\mathrm{mg} / \mathrm{l}$ & 100 & 130 & 482 \\
\hline Poliškumas & - & Polinis & Nepolinis & Polinis \\
\hline $\begin{array}{l}\text { Topologinio } \\
\text { polinio paviršiaus } \\
\text { plotas }\end{array}$ & $\AA^{2}$ & 17,1 & 0 & 1 \\
\hline $\begin{array}{l}\text { Henrio dèsnio } \\
\text { konstanta (esant } \\
25^{\circ} \mathrm{C} \text { ) }\end{array}$ & $\mathrm{atm}-\mathrm{m}^{3} / \mathrm{mol}$ & $1,87 \cdot 10^{-5}$ & $7,18 \cdot 10^{-3}$ & $1,61 \cdot 10^{-5}$ \\
\hline
\end{tabular}

Kapiliariniam bioįkrovos drèkinimui užtikrinti užpildyti vamzdeliai buvo i̇merkiami ị biogeninių elementų tirpalą. Mineralinių druskų tirpalas, užtikrinantis mikroorganizmų vystymąsi, buvo gaminamas iš dikalcio fosfato, kalio chlorido, magnio sulfato, geležies sulfato ir natrio nitrato: $\mathrm{K}_{2} \mathrm{HPO}_{4}-1 \mathrm{~g}, \mathrm{KCl}-0,5 \mathrm{~g}$, $\mathrm{MgSO}_{4} \cdot 7 \mathrm{H}_{2} \mathrm{O}-0,5 \mathrm{~g}, \mathrm{FeSO}_{4} \cdot 7 \mathrm{H}_{2} \mathrm{O}-0,1 \mathrm{~g}, \mathrm{NaNO}_{3}-0,9 \mathrm{~g}$, vanduo $-1000 \mathrm{~g}$ (Zagorskis et al., 2012). Šis tirpalas buvo ịpiltas ị biofiltro rezervuarą iki $18 \mathrm{~cm}$ aukščio. Poringa bioịkrovos struktūra užtikrino kapiliarinị biofiltro drèkinimo efektą. 
Oro santykinis drégnis ir temperatūra prie biofiltro buvo vertinami naudojantis drégmès matuokliu M0290. Abiejų eksperimentų vidutinè kambario oro temperatūra siekè $21,5^{\circ} \mathrm{C}$, santykinis drègnis - 54,6\%. Dèl bioịkrovos reikiamos temperatūros biofiltre palaikymo oro srovè buvo šildoma dujų iejjimo vamzdyje ịrengtu temperatūros reguliatoriumi. Abiejų eksperimentų metu biofiltro įèjimo vamzdyje buvo palaikoma vidutinè $33,1^{\circ} \mathrm{C}$ temperatūra, išèjimo vamzdyje $-24{ }^{\circ} \mathrm{C}$, rezervuare $-26,6^{\circ} \mathrm{C}$. Galima teigti, kad biofiltro viduje buvo palaikomas mezofilinè temperatūra (nuo 15 iki $26^{\circ} \mathrm{C}$ ). Vidutinè oro temperatūra visame biofiltre siekè $27,6^{\circ} \mathrm{C}$. Nors temperatūra biofiltre buvo veikiama aplinkos temperatūros, oro temperatūros vertès buvo optimaliame intervale, reikalingame teršalams šalinti, t. y. nuo 15 iki $35^{\circ} \mathrm{C}$ (Pagans et al., 2005). Biofiltro iejjimo vamzdyje buvo palaikomas vidutinis $53,6 \%$ oro drègnis, išejimo vamzdyje $-95,8 \%$, rezervuare $-61,9 \%$. Vidutinis oro drègnis visame biofiltre siekè 70,4\%. Biofiltre rekomenduojama išlaikyti $85-95 \%$ oro drègni (Baltrènas et al., 2015). Pirmasis tyrimas buvo atliktas esant vidutiniam $0,37 \mathrm{~m} / \mathrm{s}$ oro srauto greičiui, antrasis $-0,32 \mathrm{~m} / \mathrm{s}$. Oro srovè buvo tiekiama ị irengini naudojantis ventiliatoriumi, irengtu oro tiekimo vamzdyje. Oro greitis biofiltre buvo vertinamas naudojantis „Testo 400“ prietaisu.

Po biofiltracijos tyrimo buvo vertinamas bioanglies ir plaušo mišinio drègmès kiekis. Drègmé bioịkrovoje buvo ịvertinta svoriniu metodu (Zagorskis et al., 2012). Svorinis metodas remiasi masės kiekio sumažèjimu, šiuo atveju drègmès kiekio sumažejjimu bioịkrovoje po džiovinimo (1 val. prie $\left.105^{\circ} \mathrm{C}\right)$. Norint išlaikyti bioịkrovą drègną viso tyrimo metu, apytiksliai 101 biogeninio tirpalo buvo išlaikoma rezervuare kiekvieną dieną. Drègmès kiekis $(D K)$ buvo apskaičiuotas remiantis formule (Brischke, Wegener, 2019):

$$
D K=\frac{m_{\text {drégnos }}-m_{\text {sausos }}}{m_{\text {sausos }}} \times 100 \% \text {. }
$$

Bioịkrovos pH buvo ịvertinta $0,01 \mathrm{M} \mathrm{CaCl}_{2}$ tirpale santykiu 1:5 (EBC, 2012). Suspensija buvo kratoma 1 valandą ir paskui $\mathrm{pH}$ vertintas naudojantis „Mettler Toledo Seven Multi“ $\mathrm{pH}$ matuokliu. Biogeninio tirpalo $\mathrm{pH}$ taip pat buvo vertinamas naudojantis „Mettler Toledo“ $\mathrm{pH}$ matuokliu (Baltrènas, Mačaitis, 2014). Tyrimo metu biogeninio tirpalo $\mathrm{pH}$ sieke $8,29 \pm 0,05$. pH sąlygos, reikalingos efektyviam dujų valymui biologinio valymo sistemose, yra nuo 6 iki 8 heterotrofinių bakterijų atveju (Revah et al., 2011). Tirpalo temperatūra buvo fiksuojama spirito termometru. Tam, kad būtų galima palaikyti pastovią apie $30{ }^{\circ} \mathrm{C}$ tirpalo temperatūrą, apatineje biofiltro rezervuaro dalyje buvo ịrengtas kaitinimo elementas. Vidutinè biogeninio tirpalo temperatūra siekè $32 \pm 1{ }^{\circ} \mathrm{C}$.

Buvo atlikti du eksperimentai siekiant ịvertinti teršalų šalinimo efektyvumą esant dviem skirtingoms bioịkrovoms: 1) nemodifikuotos pušies medienos bioanglies ir plaušo mišinio; 2) ramnolipidinio tirpalo garais modifikuotos pušies 
medienos bioanglies ir plaušo mišinio. Eksperimentų trukmė kiekvienos biofiltro bioikrovos atveju, praejjus 2 savaitems po mikroorganizmų suaktyvinimo periodo, siekė 5 dienas. Po ịkrovos aktyvinimo periodiškai 5 paras po $30 \mathrm{~min}$. ị biofiltrą buvo tiekiami $300 \mathrm{mg} / \mathrm{m}^{3}$ koncentracijos acetono garai, $300 \mathrm{mg} / \mathrm{m}^{3}$ koncentracijos ksileno garai ir $300 \mathrm{mg} / \mathrm{m}^{3}$ koncentracijos amoniako garai. Junginio koncentracija buvo nustatoma fotojonizacijos detektoriumi, „MiniRAE 2000“ prietaisu (amerikiečių „RaeSystems“ įmonè) dviejuose taškuose (kiekviename po 5 min.). Junginių koncentracijos aptikimo intervalas siekè nuo 0 iki 999 ppm. Kiekvienas matavimas kartotas tris kartus. Biofiltro oro valymo efektyvumas buvo paskaičiuotas remiantis šia formule:

$$
E=\frac{C_{1}-C_{2}}{C_{1}} \times 100 \%,
$$

čia $E$ - biofiltro valymo efektyvumas, \%; $C_{1}$ - teršalo koncentracija prieš valymą, $\mathrm{mg} / \mathrm{m}^{3} ; C_{2}$ - teršalo koncentracija po valymo, $\mathrm{mg} / \mathrm{m}^{3}$.

\subsection{Bioanglies poveikis dirvožemio cheminių ir hidrofizikinių savybių didinimui}

Tyrimo tikslas - ịvertinti tyrimo laiko, žemès dirbimo būdo tręšimo sistemos bei bioanglies ịterpimo normos ịtaką smèlingojo rudžemio drèkumui. Tyrimams dirvožemis buvo renkamas iš Kẻdainių rajono, nes šis regionas yra intensyviausiai veikiamas žemdirbystès ir greičiausiai degraduojamas (vyksta intensyvi erozija, rūgštėjimas, mažèja organinès medžiagos kiekis, mineralinès trąšos yra išplaunamos i požeminius vandenis, mažejja dirvožemyje sulaikomų maistingujų medžiagų kiekis, dirvožemis yra slegiamas sunkios žemės ūkio technikos), dèl ko prastèja jo kokybè.

Lauko eksperimentas buvo atliktas Lietuvos agrarinių ir miškų mokslų centro Žemdirbystės institute, o dirvožemio fizikinių ir cheminių savybių ịvertinimas Vilniaus Gedimino technikos universiteto Aplinkos apsaugos institute. Tyrimai atlikti $2019 \mathrm{~m}$. ( $55^{\circ} 23^{\prime} \mathrm{N}$ ir $\left.23^{\circ} 51^{\prime} \mathrm{E}\right)$, vykdant ilgalaikị (20 metų) žemès dirbimo ir tręšimo sistemų lauko eksperimentą. Dirvožemis - smélingojo lengvojo priemolio rudžemis (Endocalcari-Epihypogleyic Cambisol). Remiantis granuliometrine dirvožemio sudètimi, dirvožemis daugiausia turejjo smèlio dalelių $(2-0,05 \mathrm{~mm} ; \quad 53,7 \%)$, vidutiniškai - dulkių $(0,05-0,002 \mathrm{~mm} ; 32,6 \%)$ ir mažiausiai - molio $(<0,002 \mathrm{~mm} ; 13,7 \%)$. Lauko eksperimentų planas pateiktas 2.6 paveiksle. 


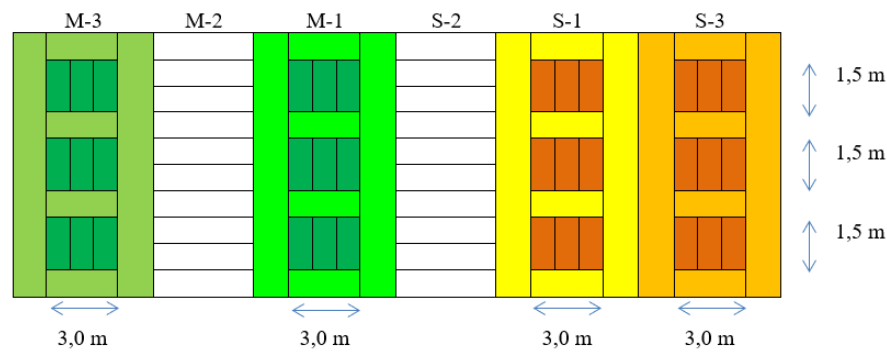

2.6 pav. Lauko eksperimentų planas (išdèstyta ilgalaikio lauko bandymo skirtingų technologijų plotuose)

Fig. 2.6. Plan of field experiments (located in the areas of long-term field testing of different technologies)

Tyrimo schema. Veiksnys A - žemès dirbimas:

- $\mathrm{S}$ - neariminis seklus žemès dirbimas (skutimas $10-12 \mathrm{~cm}+$ priešsèjinis purenimas $5-6 \mathrm{~cm})$;

- $\mathrm{M}$ - tiesioginè sèja (dirva nedirbama, tiesioginè sèja su diskine sejjamaja, turinčia rotorinị dirvos purenimo agregatą).

Veiksnys B - tręšimas:

- netręšta;

- tręšta mineralinėmis NPK trąšomis pagal dirvožemio savybes ir planuojamą derlių.

Veiksnys $\mathrm{C}$ - bioanglies įterpimo norma:

- $0 \mathrm{t} / \mathrm{ha}$

$-5 \mathrm{t} / \mathrm{ha}$;

- $15 \mathrm{t} / \mathrm{ha}$.

Bioanglis išberta prieš pat vasarinio kvietrugio sèją, ịterpta sèjos metu (2019 m. balandžio 16 d.) su rotoriniu dirvos purenimo agregatu. Eksperimente naudota pušies medienos bioanglis $\left(450{ }^{\circ} \mathrm{C}, 2\right.$ val.). Naudotos šios mineralinès trąšos: amonio nitratas (34,5\%), granuliuotas superfosfatas (19\%) ir kalio chloridas $(60 \%)$.

Remiantis meteorologiniais duomenimis, vidutiniškai šalčiausias mėnuo tiriamuoju laikotarpiu $\left(2019 \mathrm{~m}\right.$. kovas-rugpjūtis) buvo kovas $\left(3,3^{\circ} \mathrm{C}\right.$; daugiamete norma $\left.-0,6{ }^{\circ} \mathrm{C}\right)$, o šilčiausias - birželis $\left(20,6{ }^{\circ} \mathrm{C}\right.$; daugiametè norma $\left.-15,7{ }^{\circ} \mathrm{C}\right)$ (2.7 pav.). Kritulių balandžio mėnesi nebuvo visai (daugiametė norma $37,6 \mathrm{~mm})$, o daugiausia jų iškrito rugpjūčio mèn. $(35,7 \mathrm{~mm}$; daugiametė norma $73,2 \mathrm{~mm})$. Vasaros sezono metu sausiausias mènuo buvo birželis $\left(20,6^{\circ} \mathrm{C}\right.$ ir $5,37 \mathrm{~mm}$ ), todèl šiuo sausuoju periodu dirvožemis tapo visiškai sausas, o vasaros pabaigoje (rugpjūčio mèn.) buvo stebimas didžiausias kritulių kiekis, palyginti su visu tiriamuoju laikotarpiu. 


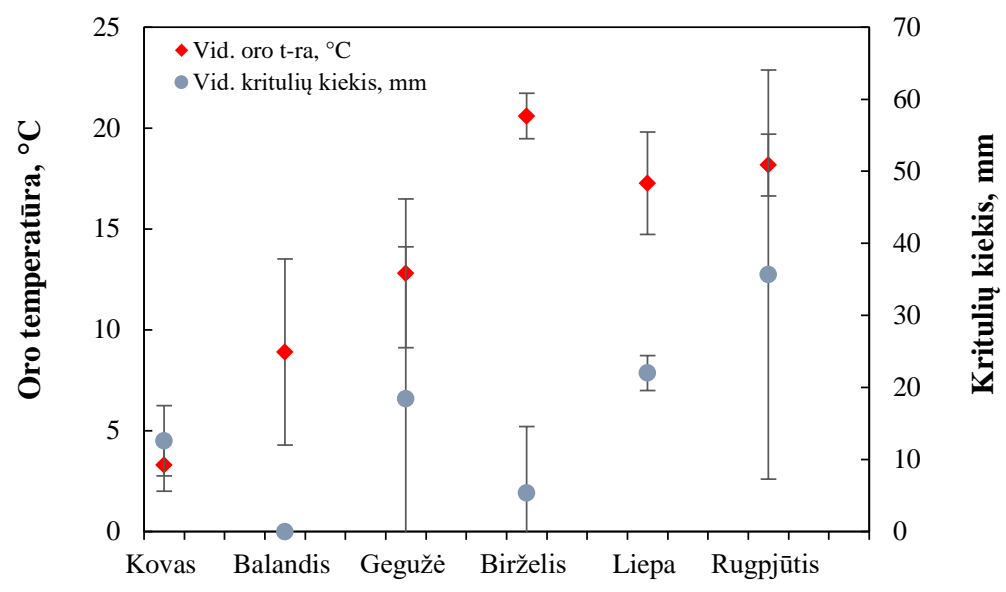

2.7 pav. Dotnuvos meteorologinès stoties vidutinès mènesinès temperatūros $\left({ }^{\circ} \mathrm{C}\right)$ bei kritulių kiekiai $(\mathrm{mm})$ remiantis kiekvieno ménesio dekadų duomenimis, $\mathrm{n}=3$

Fig. 2.7. Average monthly temperature $\left({ }^{\circ} \mathrm{C}\right)$ and precipitation $(\mathrm{mm})$ based on decades of monthly data in Dotnuva, $\mathrm{n}=3$

Dirvožemio bandiniai buvo renkami dviem laikotarpiais: praejus 3 ir 6 mėnesiams nuo eksperimento pradžios. Dirvožemio grąžtu bandiniai paimti iš 0 $15 \mathrm{~cm}$ dirvožemio sluoksnio. Iš bandinių pašalintos bet kokios augalinès liekanos. Dirvožemio mėginiai buvo džiovinami natūraliomis sąlygomis $20^{\circ} \mathrm{C}$ temperatūroje ir persijoti per $2 \mathrm{~mm}$ skersmens sietą tolesnèms analizėms. Dirvožemio drèkumas buvo vertinamas taikant VLSL testą (Glab et al., 2016). Dirvožemio vandens laikomoji geba įvertinta remiantis formule (Brischke, Wegener, 2019):

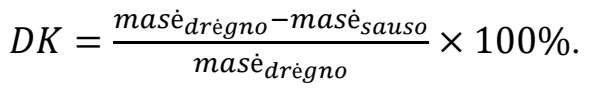

Dirvožemio drègmès kiekis apskaičiuotas pagal šią formulę (Brischke, Wegener, 2019):

$$
V S G=\frac{\text { mase் }_{\text {drègno }}-\text { mase }_{\text {sauso }}}{\text { masé }_{\text {sauso }}} \times 100 \% .
$$

Dirvožemio $\mathrm{pH}$ buvo nustatytas 1:1 dirvožemio: vandens suspensijoje (Motuzas et al., 1996). Dirvožemio elektrinis laidis $(\mu \mathrm{s} / \mathrm{cm})$ taip pat buvo ịvertintas 1:1 dirvožemio:vandens suspensijoje pagal tūrị. Elektrinio laidžio rezultatai reprezentuoja dirvožemio porose buvusių vandens druskų 
koncentraciją. Dirvožemio organinè medžiaga $(\mathrm{OM})$ buvo nustatyta dirvožemio išdeginimo metodu, pagrịstu sauso $\left(105^{\circ} \mathrm{C}\right)$ dirvožemio deginimu $\left(550^{\circ} \mathrm{C}\right)$, kol pasiekiama pastovi bandinio masè. Dirvožemio OM kiekis apskaičiuotas pagal masių skirtumą prieš ir po deginimo (Buivydaitè, Motuzas, 2000).

Bioanglis buvo gaminama iš pušies medienos $\left(450{ }^{\circ} \mathrm{C}, 2\right.$ val.) mufelinèje krosnyje (SNOL2000/2002). Bioanglies pH nustatyti mėginiai buvo maišomi su $0,1 \mathrm{~N} \mathrm{KCl}$ tirpalu santykiu 1:10 (Ronsse et al., 2013). Po $10 \mathrm{~min}$. kratymo, pH bioanglies suspensijoje buvo ịvertinta naudojantis $\mathrm{pH}$ matuokliu. Katijonų mainų geba bioanglyje buvo ịvertinta taikant amonio acetato pakeitimo metodą (Komkiene, Baltrenaite, 2016). Bioanglies drèkumas, mėginių elementinè sudetis $(\mathrm{C}, \mathrm{H}, \mathrm{N}, \mathrm{O}, \mathrm{S})$, funkcinès grupès, elektrinis laidis ir savitasis paviršiaus plotas ịvertinti 2.2 ir 2.3 poskyriuose aprašytais metodais. Potencialiai toksiškų elementų koncentracija (PTE) bioanglyje buvo ịvertinta naudojantis atominès absorbcijos spektrometru (Agrafioti et al., 2012). Sausi bioanglies méginiai buvo deginti $450^{\circ} \mathrm{C} 2,5$ val. iki pelenų. Tuomet kiekvieno mèginio buvo atsverta po $0,5 \mathrm{~g}$ bei sumaišyta su $3 \mathrm{ml} 65 \%$ azoto rūgštimi ir $9 \mathrm{ml} 37 \%$ druskos rūgštimi. Tirpalas patalpintas i „Milestone ETHOS“ apdorojimo talpyklą. Po proceso gautas tirpalas kolboje prafiltruotas ir atskiestas dejonizuotu vandeniu iki $50 \mathrm{ml}$.

Reikšmingiems skirtumams nustatyti tarp tirtų veiksnių kombinacijų (tyrimo datos, tręšimo / netręšimo ir žemès dirbimo / nedirbimo sistemos ir bioanglies ịterpimo normos) ịtakos dirvožemio fizikinėms ir cheminèms savybėms buvo atlikta trijų veiksnių ANOVA analizė (paketas ,STATISTICA Base“). Skirtumai tarp tiriamujų grupių buvo dideli, jei $p<0,05$. Taip pat pateiktos mažiausio patikimo skirtumo ribos (R05).

\subsection{Kapiliarinio kilimo greičio bioanglyje skaitinis modeliavimas}

Tyrimo tikslas - naudojantis „COMSOL Multiphysics“ programa ir multifazès tekejjimo poringojoje medžiagoje modeliu, sumodeliuoti vandens kapiliarinio pakilimo aukšti bioanglyje priklausomai nuo laiko. Gauti modeliavimo rezultatai buvo lyginami su teorinio tyrimo ir eksperimentiniais rezultatais.

Pasirinktas 2D modelis su stačiakampe geometrija, kurios ilgis buvo $12,5 \mathrm{~cm}$, o plotis $-2 \mathrm{~cm}$. Skirtingos medžiagų savybès, naudotos šiame modelyje, paimtos iš 2.1 skyrelio (2.3 lentelè). Modelyje taikomos trys pagrindinès prielaidos: yra vandens, oro ir poringosios medžiagos fazès. Brooks ir Corey modelis kapiliariniam slègiui ir santykiniam laidumui taikomas nuo laiko priklausančiam modeliavimui.

Šiame tyrime naudojamas multifazès tekèjimas poringojoje medžiagoje, kuris jungia Darsi dèsni ir fazès transportą poringosios medžiagos paviršiumi. 
Fazès transportas poringosios medžiagos paviršiumi aprašomas atskiromis lygtimis tūrio frakcijai $s_{i}$ :

$$
\frac{\partial}{\partial t}\left(\varepsilon_{p} \rho_{s} s_{i}\right)+\nabla \cdot\left(-\rho_{s} K \frac{K_{i}}{\mu}\left(\nabla p_{i}-\rho_{s} g\right)\right)=Q_{i}=0,
$$

čia $\varepsilon_{p}$ - poringumas, $\% ; K$ - laidumas, $\mathrm{m}^{2} ; K_{\mathrm{i}}$ - santykinis laidumas, $\mathrm{m}^{2} ; \mu-$ skysčio dinaminè klampa, $\mathrm{Pa} \cdot \mathrm{s} ; p_{i}-$ slègis, $\mathrm{Pa} ; \rho_{s}-$ skysčio tankis, $\mathrm{kg} / \mathrm{m}^{3}$. Naudojantis Brooks ir Corey modeliu, kapiliarinis slègis apibrezžiamas taip:

$$
p_{c}=p_{e c} \frac{1}{\left(\overline{s_{w}}\right)^{1 / \lambda_{p}}},
$$

čia $\lambda_{\mathrm{p}}-$ porų pasiskirstymo indeksas. Santykiniai drèkinančios ir nedrèkinančios fazès laidumai apibrèžiami taip:

$$
\begin{gathered}
\kappa_{r s_{w}}=\left(\overline{s_{w}}\right)^{\left(3+2 / \lambda_{p}\right) .} \\
\kappa_{r s_{n}}=\bar{s}_{n}^{2}\left(1-\left(1-\bar{s}_{n}\right)^{\left(1+2 / \lambda_{p}\right)}\right) .
\end{gathered}
$$

Darsi dèsnio paviršius jungiasi su Darsi lygtimi tęstine lygtimi:

$$
\frac{\partial}{\partial t}\left(\rho \varepsilon_{p}\right)+\nabla \cdot \rho\left[-\frac{\kappa}{\mu}(\nabla p)\right]=0
$$

čia $\rho$-tankis, $\mathrm{kg} / \mathrm{m}^{3} ; \mu$-dinaminè klampa, $\mathrm{Pa} \cdot \mathrm{s}$.

\subsection{Antrojo skyriaus išvados}

1. Suformuota teorinių tyrimų metodika, leidžianti ịvertinti skysčių kapiliarinio kilimo greiti bioanglyje remiantis modifikuota Luko ir Vašburno lygtimi. I naujają lygtị ịtraukiamas efektyvusis spindulys, išbrinkusio kapiliaro spindulys, tūrinis medžiagos brinkimas, nes kai bioanglis kontaktuoja su skysčiu, ji deformuojasi ir brinksta.

2. Bioanglies fizikinès ir cheminès savybès buvo vertinamos remiantis Europiniu bioanglies sertifikatu. Buvo analizuojamos tokios savybès, kaip peleningumas, $\mathrm{pH}$, elektrinis laidis, elementinè sudètis, vandens laikomoji geba. Kitos savybės vertintos remiantis kitų autorių metodikomis. Daugialypė regresinė analizė buvo naudota bioanglies drèkumo ir vandens laikomosios gebos prognozei remiantis $\mathrm{C}, \mathrm{H}, \mathrm{O}$ kiekių, $\mathrm{pH}$, elektrinio laidžio, peleningumo, bendrojo porų tūrio, mikroporų tūrio, porų dydžio, $-\mathrm{OH}$ ir $\mathrm{C}-\mathrm{O}$ funkcinių grupių intensyvumo savybèmis.

3. Bioanglies drèkumui ịvertinti buvo taikomas vandens lašelio skverbimosi laiko testas, etanolio lašelio molingumo testas ir kontakto laipsnio analizè. Remiantis rezultatais vandens lašelio skverbimosi laiko testas parode didžiausią 
bioanglies drèkumo variaciją nuo hidrofiliškos iki ypatingai hidrofobiškos, todèl šis metodas yra tinkamesnis bioanglies atveju nei kiti drèkumo metodai.

5. Remiantis bioanglies naudojimo biofiltre metodika, buvo nustatomas lakiujų organinių (acetono ir ksileno) ir neorganinių (amoniako) teršalų šalinimo efektyvumas priklausomai nuo nemodifikuotos bioanglies ir plaušo bioịkrova bei ramnolipidinio tirpalo garais modifikuotos bioanglies ir plaušo bioịkrova. Modifikuotos garais bioanglies atveju, acetono, ksileno ir amoniako pašalinimo efektyvumas siekè atitinkamai $93 \%, 72 \%$ ir $96 \%$.

7. Vandens kapiliarinio kilimo greičiui ịvertinti bioanglyje buvo pasirinkta „Comsol Multiphysics“ programa remiantis Darsi dèsniu ir fazès transporto poringosios medžiagos paviršiumi modeliu. Ši programa pranaši tuo, kad leidžia naudoti ịvairius kietosios medžiagos ir skysčio ịvesties parametrus bei ịvertinti jų itaką vandens kapiliarinio pakilimo pokyčiams. 



\section{Bioanglies drèkumo teorinių ir eksperimentinių tyrimų rezultatai}

Skyriuje pateikiami kapiliarinio kilimo bioanglyje eksperimentiniai ir teoriniai rezultatai, pirolizès temperatūros ir laiko ịtakos bioanglies, pagamintos iš penkių lignoceliuliozinių žaliavų, fizikinėms ir cheminėms savybėms rezultatai, bioanglies drékumo bei vandens laikomosios gebos ryšio su jos kitomis fizikinèmis ir cheminèmis savybėmis daugialypès regresinès analizès rezultatai, bioanglies drékumo, ívertinto skirtingais metodais, rezultatai, bioanglies paviršiaus fizikinių ir cheminių savybių rezultatai modifikavus ją tirpalų garais bei azoto rūgšties tirpalais. Pristatomi lakiụjų organinių ir neorganinių teršalų šalinimo biofiltre rezultatai, bioanglies naudojimo smèlingojo rudžemio fizikinèms ir cheminèms savybèms didinti rezultatai, taip pat skaitinio modeliavimo rezultatai.

Skyriaus tematika paskelbti trys autorès moksliniai straipsniai žurnaluose su citavimo indeksu (Usevičiūtè, Baltrènaitè-Gedienė, 2020; Usevičiūtè, BaltrènaitèGedienè, 2021; Usevičiūtè et al., 2021). 


\subsection{Kapiliarinio kilimo greičio bioanglyje teoriniai tyrimai}

Kapiliarinio kilimo fenomenas buvo dažnai interpretuojamas modeliais, įtraukiančiais cilindrinius kapiliarinius vamzdelius, nors dabar žinoma, kad poringujų medžiagų kapiliarai dažnai yra vingiuoti. Be to, yra žinoma, kad lignoceliuliozinès medžiagos, sąveikaudamos su skysčiu, brinksta. Anksčiau medžiagos drėkumo įtaka skysčio kapiliariniam kilimui nebuvo detaliai nagrinèta. Šio tyrimo tikslas - ịvertinti skirtingo drèkumo, išreikšto kontakto laipsniu, bioanglies, priklausomai nuo dalelių dydžio, pradinès žaliavos ir modifikacijos garais, ịtaką skysčių kapiliariniam kilimui ịtraukiant medžiagos brinkimo parametrus.

Bioanglies tipų morfologija buvo charakterizuojama remiantis SEM nuotraukomis (3.1 pav.). Pušies medienos bioanglies vidutinis porų skersmuo sumažèjo po jos smulkinimo ir smulkiausios bioanglies $(<300 \mu \mathrm{m})$ vidutinis makroporų skersmuo buvo 13 ir 37 procentiniais punktais mažesnis, lyginant su stambios ir vidutinès frakcijos bioanglimi. Vidutinès frakcijos bioanglies makroporų skersmuo buvo panašus ị stambios frakcijos (atitinkamai 28 ir $20 \mu \mathrm{m}$ ). Lyginant lignoceliuliozines žaliavas (pušies medieną, pušies žievę ir kanapes), vidutiniškai didžiausiu makroporu dydžiu pasižymėjo kanapių bioanglis $(30 \mu \mathrm{m})$, kuris 16 ir 32 procentiniais punktais viršijo pušies žievès bei pušies medienos bioanglies makroporu dydį. Lyginant skirtingus modifikacijos būdus (lietaus ir ramnolipidinio tirpalo garais), lietaus garais modifikuota bioanglis turejo 17 , o ramnolipidinio tirpalo garais -8 procentiniais punktais didesni vidutini makroporu skersmenį, lyginant su nemodifikuota bioanglimi.

Bioanglis yra poringos struktūros, turi kompleksinị porų tinklą ir ịvairius plyšius, kurie susiformuoja biomasès pirolizès metu dèl greitesnio išorinio nei vidinio biomasès skaidymo greičio. Ši struktūra gali būti suskaidyta, kai yra veikiama papildomo mechaninio poveikio ir dèl to gali susiformuoti koloidai (Yang et al., 2019). Fizinis smulkinimas laikomas svarbiausiu būdu mažinant bioanglies dalelių dydį. Daugelis tyrimų bioanglies porų struktūros vystymui naudojo $\mathrm{CO}_{2}$ dujas ir tik keletas jų tyrè garu poveikị bioanglies struktūrai, ypač medienos bioanglyje, pagamintoje ịvairiose temperatūrose. Bioanglies modifikacija garais palengvina mažu porų susiliejimą ir padidina vidines ertmes, dèl to padidèja medžiagos mikroporingumas (Lou et al., 2016). Po garų poveikio bioanglies struktūra tampa poringesnè, lyginant su originalia bioanglimi, ir daugiau ant jos paviršiaus būna pasiskirsčiusių mažų porų. Bioanglies konversijos metu nuolatos formuojasi mikroporos ir vystosi mezoporos. Nuolatinis ir tolygus porų vystymasis rodo besijungiančių porų tinklą. Mikroporų formavimasis rodo bioanglies aktyvių vietų reakcijas ant išorinio paviršiaus bei uždarų porų atsiverimą, dèl to didejja bioanglies paviršiaus plotas ir porų tūris. 
a)

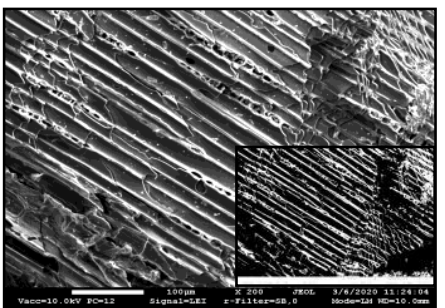

c)

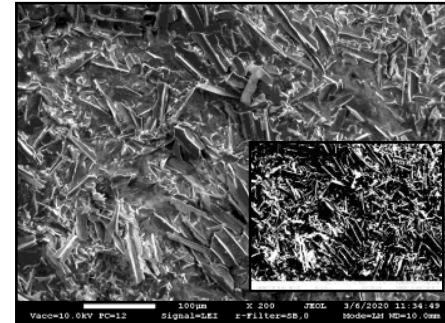

e)

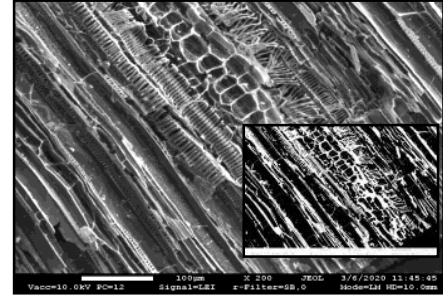

g)

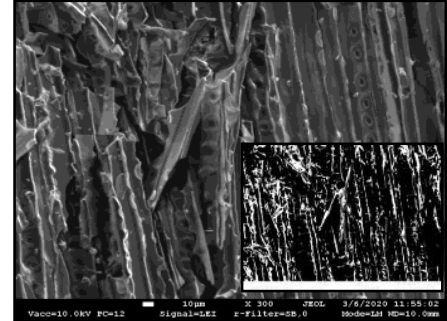

b)

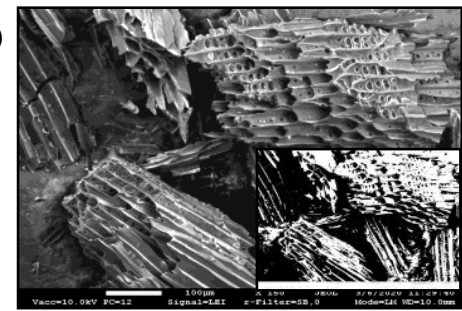

d)

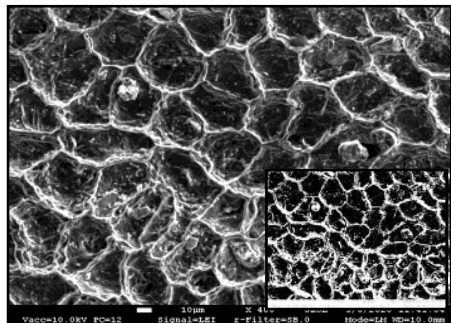

f)

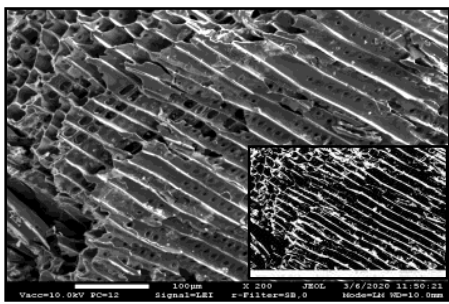

h)

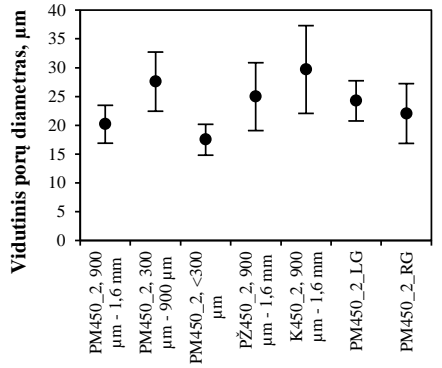

3.1 pav. Bioanglies nuotraukos, gautos naudojantis skenuojančiu elektroniniu mikroskopu: a) stambi pušies medienos bioanglis; b) vidutinė pušies medienos bioanglis; c) smulki pušies medienos bioanglis, d) pušies žievès bioanglis;

e) kanapių bioanglis; f) pušies medienos bioanglis, modifikuota lietaus garais; g) pušies medienos bioanglis, modifikuota ramnolipidinio tirpalo garais; h) vidutinis makroporu skersmuo, $\mu \mathrm{m}, n=30$

Fig. 3.1. Biochar images obtained using a scanning electron microscope: a) coarse pine wood biochar; b) medium pine wood biochar;

c) fine pine wood biochar; d ) coarse pine bark biochar; e) coarse hemp biochar; f) coarse pine wood biochar modified by the steam of rain water; g) coarse pine wood biochar modified by the steam of rhamnolipid solution; $h$ ) average diameter of macropores, $\mu \mathrm{m}, n=30$ 
Šilumos adsorbcija yra tipinis fenomenas, atsirandantis brinkstant medžiagoms (Shi, Gardner 2000). Kai skystis skverbiasi ir yra adsorbuojamas ant vidinio mikroporu paviršiaus, medžiagos ir skysčio energija paprastai sumažeja. Dalis sistemos energijos išsiskiria šilumos pavidalu, kuri vadinama brinkimo arba adsorbcijos šiluma. 3.2 paveiksle rodomas šilumos ịvertinimas vandens kapiliarinio kilimo metu pušies medienos bioanglyje, kai ị vamzdelị buvo ịdèta termopora. Rezultatai rodo, kad didžiausias temperatūros šuolis ịvyko (nuo $24,2^{\circ} \mathrm{C}$ iki $27,5^{\circ} \mathrm{C}$ ) kapiliarinio kilimo pradžioje, praèjus 4 valandoms nuo eksperimento pradžios. Panašiai tuo pačiu laikotarpiu i̇vyksta staigus kapiliarinio pakilimo aukščio šuolis nuo 2,6 iki $6,6 \mathrm{~cm}$. Šis temperatūros pakilimo fenomenas rodo, kad brinkimas įvyko kapiliarinio kilimo proceso pradžioje, po kurios šiluma nebeišsiskyrè ir pradèjo mažèti esant ilgalaikiam kapiliariniam kilimui (nuo 6 iki 24 val.).

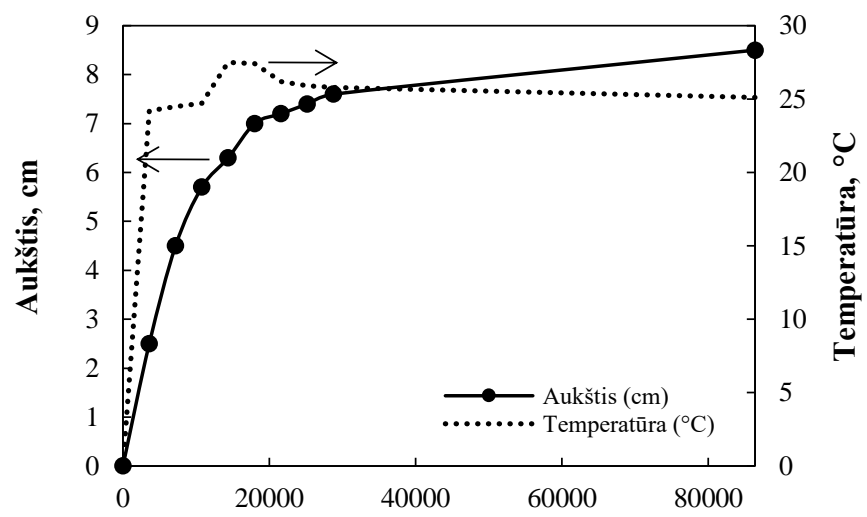

Laikas, $s$

3.2 pav. Temperatūros kilimas stambios frakcijos pušies medienos bioanglyje priklausomai nuo laiko vandens kapiliarinio kilimo metu, $n=3$

Fig. 3.2. Temperature rise in coarse fraction of pine wood biochar as a function of time during water capillary rise, $n=3$

Vertinant teorinį lakiujų organinių (acetono, tolueno, ksileno ir heksano) bei amoniako tirpalų kapiliarinio kilimo aukštị stambios frakcijos pušies medienos bioanglyje, matyti, kad iš visų junginių heksanas pasižymėjo didžiausiu kapiliarinio pakilimo aukščiu, kuris siekè $26 \mathrm{~cm}$ praejus 8 valandoms nuo eksperimento pradžios (3.3 pav.). Tokị rezultatą galèjo lemti mažiausia šio tirpalo paviršiaus ịtemptis $(0,02 \mathrm{~N} / \mathrm{m})$ ir palyginti maža dinaminè klampa $\left(0,14 \mathrm{mN} \cdot \mathrm{s} / \mathrm{m}^{2}\right)$. Mažiausiu pakilimo aukščiu pasižymėjo vanduo ir amoniakas (atitinkamai 9,87 ir $11,8 \mathrm{~cm}$ praejus 8 val.). Tai galima aiškinti panašiai didelèmis 
šiu tirpalų paviršiaus ịtemptimis, kurios atitinkamai siekẻ 0,07 ir $0,08 \mathrm{~N} / \mathrm{m}$. Taip pat vanduo pasižymejjo didžiausia dinamine klampa $\left(1 \mathrm{mN} \cdot \mathrm{s} / \mathrm{m}^{2}\right)$ ir tankiu $\left(0,995 \mathrm{~g} / \mathrm{cm}^{3}\right)$. Teorinis nagrinètų skysčių maksimalus kapiliarinis pakilimo aukštis rikiuojasi tokia tvarka: vanduo $(17,1 \mathrm{~cm})<$ amoniakas $(21,7 \mathrm{~cm})<$ ksilenas $(30,3 \mathrm{~cm})<$ toluenas $(36,8 \mathrm{~cm})<$ acetonas $(39,5 \mathrm{~cm})<$ heksanas $(45,9 \mathrm{~cm})$. Panašiai tik atvirkštine tvarka tirpalai išsidèsto pagal paviršiaus itempties vertes: amoniakas $(0,8 \mathrm{~N} / \mathrm{m})<$ vanduo $(0,07 \mathrm{~N} / \mathrm{m})<$ ksilenas $\quad(0,03 \mathrm{~N} / \mathrm{m})<$ toluenas $\quad(0,03 \mathrm{~N} / \mathrm{m})<$ acetonas $(0,03 \mathrm{~N} / \mathrm{m})<$ heksanas $(0,02 \mathrm{~N} / \mathrm{m})$. Apibendrintai galima teigti, kad skysčio paviršiaus įtemptis yra parametras, kuris stipriai veikia skysčio kapiliarinị pakilimo aukštị vertikaliame vamzdelyje, užpildytame poringaja medžiaga, ir kuo jis yra mažesnis, tuo kapiliarinis pakilimo aukštis yra didesnis.

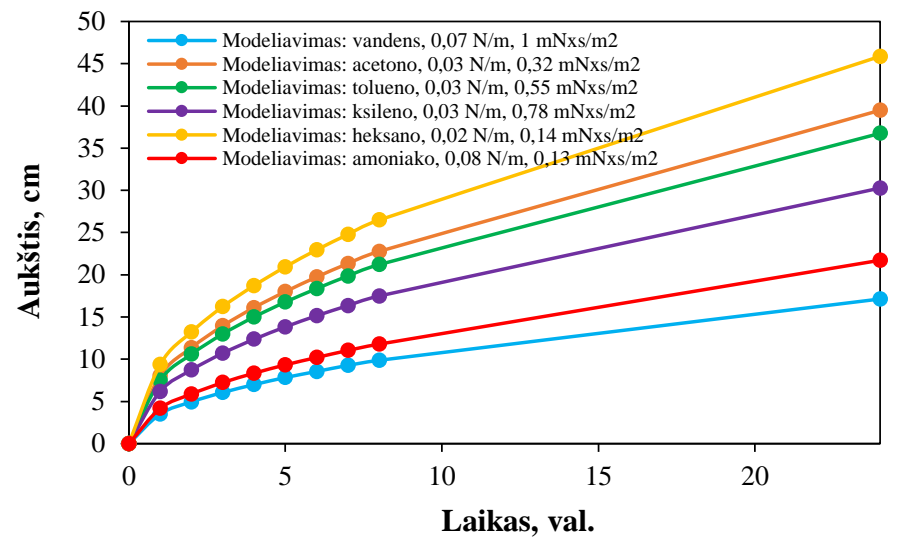

3.3 pav. Kapiliarinio kilimo greičio $(\mathrm{cm} / \mathrm{s})$ modeliavimo rezultatai priklausomai nuo skirtingų tirpalų ( $1 \mathrm{~mol} / \mathrm{l}$ ) savybių (paviršiaus ịtempties ir dinaminès klampos) remiantis modifikuota Luko ir Vašburno lygtimi, $n=3$

Fig. 3.3. Modelling results for the capillary rise rate $(\mathrm{cm} / \mathrm{s})$ depending on the properties of different solutions $(1 \mathrm{~mol} / \mathrm{l})$ (surface tension and dynamic viscosity) based on the a modified Lucas-Washburn equation, $n=3$

Lyginant lakiụjų organinių junginių tirpalų kapiliarinį kilimą pagal šių junginių Henrio konstantas, matyti tendencija, kad kuo ši konstanta yra mažesnè, tuo kapiliarinis kilimas yra aukštesnis. Kapiliarinio kilimo aukščiai skirtingų lakiụjų organinių junginių atvejais priklausomai nuo jų Henrio konstantų rikiuojasi tokia tvarka: acetonas $\left(h(8)=22,8 \mathrm{~cm}, \quad K_{H}=0,00159\right)<$ toluenas $\left(h(8)=21,2 \mathrm{~cm}, \mathrm{~K}_{\mathrm{H}}=0,235\right)<\operatorname{ksilenas}\left(h(8)=17,49 \mathrm{~cm}, K_{H}=0,3\right)$.

3.4 paveiksle parodyti teoriniai acetono kapiliarinio pakilimo aukščiai stambios frakcijos pušies medienos bioanglyje priklausomai nuo skirtingos acetono koncentracijos. Matyti, kad, didejant acetono koncentracijai nuo 0,15 iki 
$1 \mathrm{~mol} / \mathrm{l}$, kapiliarinis pakilimo aukštis taip pat didejo nuo 14,4 iki $22,8 \mathrm{~cm}$ praejjus 8 val. nuo eksperimento pradžios. Didejjant acetono koncentracijai 7 kartus, maksimalus kapiliarinis pakilimo aukštis didejjo 1,6 karto (nuo 24,9 iki 39,5 cm). Galima teigti, kad paviršiaus įtemptis ir dinaminè klampa yra parametrai, kurie labiausiai veikè kapiliarinị pakilimo aukštį, nes geriausio pakilimo greičio ir didèjančios koncentracijos acetono tirpalų paviršiaus įtemptis ir dinaminė klampa mažejo. Skirtingų koncentracijų acetono tirpalai pagal paviršiaus įtemptị rikiuojasi tokia tvarka: $0,15 \mathrm{~mol} / \mathrm{l}(50 \mathrm{mN} / \mathrm{m})>0,3 \mathrm{~mol} / \mathrm{l}(39 \mathrm{mN} / \mathrm{m})>0,6 \mathrm{~mol} / \mathrm{l}$ $(30 \mathrm{mN} / \mathrm{m})>1 \mathrm{~mol} / \mathrm{l}(23 \mathrm{mN} / \mathrm{m})$. Panašiai didejjant acetono tirpalo koncentracijai dinaminè klampa taip pat mažejo: $0,15 \mathrm{~mol} / \mathrm{l} \quad\left(1,2 \mathrm{mN} \cdot \mathrm{s} / \mathrm{m}^{2}\right)>0,3 \mathrm{~mol} / \mathrm{l}$ $\left(1,1 \mathrm{mN} \cdot \mathrm{s} / \mathrm{m}^{2}\right)>0,6 \mathrm{~mol} / \mathrm{l}\left(0,5 \mathrm{mN} \cdot \mathrm{s} / \mathrm{m}^{2}\right)>1 \mathrm{~mol} / \mathrm{l}\left(0,32 \mathrm{mN} \cdot \mathrm{s} / \mathrm{m}^{2}\right)$.

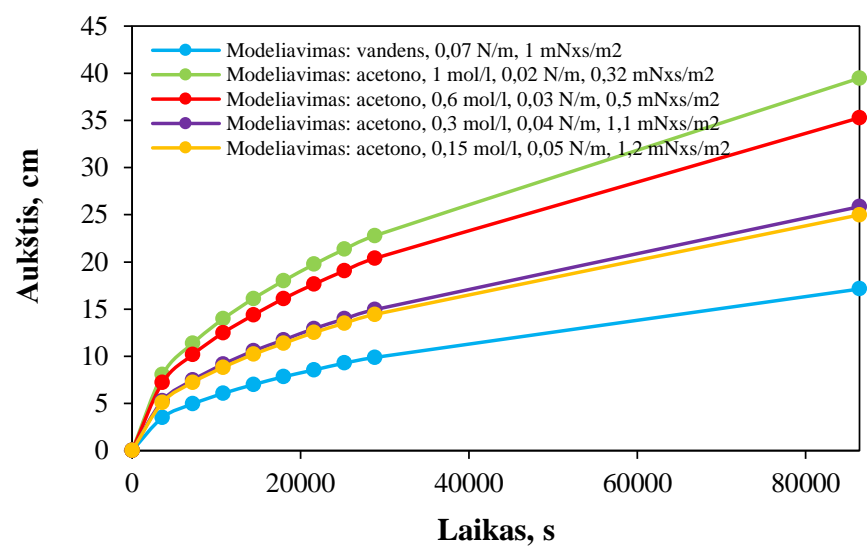

3.4 pav. Kapiliarinio kilimo greičio $(\mathrm{cm} / \mathrm{s})$ modeliavimo rezultatai priklausomai nuo acetono tirpalo koncentracijos remiantis modifikuota Luko ir Vašburno lygtimi, $n=3$

Fig. 3.4. Modelling results for the capillary rise rate $(\mathrm{cm} / \mathrm{s})$ depending on the concentration of acetone solution by the modified Lucas-Washburn equation, $n=3$

Remiantis literatūra, acetono paviršiaus įtemptis $\left(\mathrm{mJ} / \mathrm{m}^{2}\right)$ linijiškai mažeja didejjant jo tirpalo koncentracijai (mol/l) (Mochado et al., 1999). Acetono tirpalo klampa varijuoja priklausomai nuo acetono molinès frakcijos (intervale 0,3$\left.1,4 \mathrm{mN} \cdot \mathrm{s} / \mathrm{m}^{2}\right)$ ir pasiekia maksimalią vertę esant 0,15 acetono molinei koncentracijai. Svarbu pabrěžti, kad acetono tirpalo klampa nepasižymi linijine variacija priklausomai nuo tirpalo koncentracijos.

Taigi, buvo pasiūlyta modifikuota Luko ir Vašburno lygtis, kuria būtų galima modeliuoti skysčiu kapiliarinio pakilimo aukšti poringojoje medžiagoje, tokioje kaip bioanglis, kuri sugeria skysčius ir brinksta. Pateiktame modelyje buvo atsižvelgta ị beveik visas poringos terpès ir drékinamojo skysčio savybes, kurios kontroliuoja savaiminio sudrèkimo (kapiliarinio kilimo) procesą. Šiame modelyje 
buvo atsižvelgta ne tik ị medžiagos ir skysčio masę skysčio kapiliarinio kilimo metu, bet ir ị tūrinių dalelių brinkimą.

\subsection{Bioanglies drèkumo bei kitų jos fizikinių ir cheminių savybių ryšys}

Šio tyrimo tikslas - ịvertinti pirolizès temperatūros ir kaitinimo laiko poveikị lignoceliuliozinès bioanglies fizikinėms ir cheminėms savybėms. Bioanglies aplinkosauginè nauda stipriai siejasi su jos savybėmis, kurios priklauso nuo pradinès žaliavos ir pirolizès sąlygų. Remiantis ankstesniais tyrimais apie augalinès biomasės bioanglies savybių pokyčius, kaitinimo laikas turëjo reikšmingą ịtaką bioanglies savybėms žemesnès temperatūrose $\left(<500{ }^{\circ} \mathrm{C}\right)$ nei lyginant su aukštomis $\left(>500{ }^{\circ} \mathrm{C}\right)$.

Nustatyta, kad žemesnè $\left(450^{\circ} \mathrm{C}\right)$ temperatūra lèmė didesnę bioanglies išeigą. Didžiausia išeiga pasižymėjo PŽ450-1 (37,2 \%), o mažiausia-BM700-2 (13,1 \%) (3.5 pav.). Visų žaliavų atvejais $700{ }^{\circ} \mathrm{C}$ temperatūra lèmè mažesnę bioanglies išeigą. Taip pat matyti tendencija, kad ilgesnis žaliavos kaitinimas mažino bioanglies išeigą.

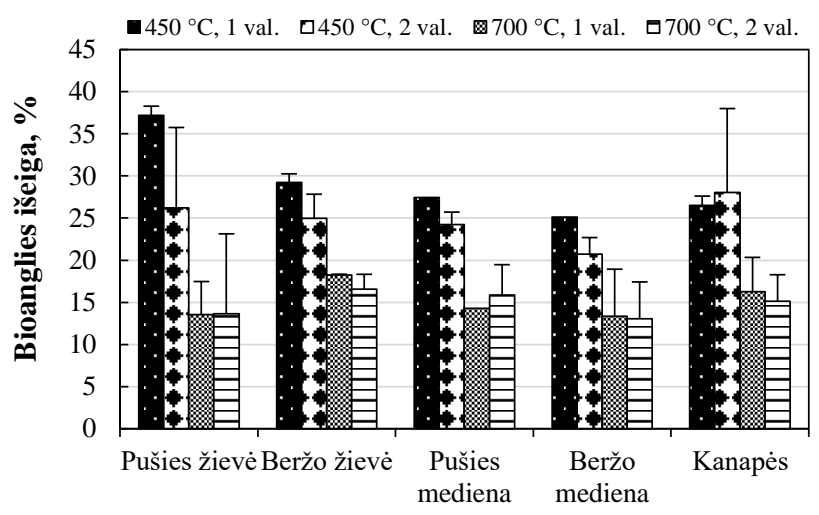

3.5 pav. Lignoceliuliozinès bioanglies tipų, pagamintų 450 ir $700{ }^{\circ} \mathrm{C}$ temperatūrose bei esant 1 ir 2 val. kaitinimo laikui, išeiga, $n=6$

Fig. 3.5. Yields of lignocellulosic biochar types produced at $450{ }^{\circ} \mathrm{C}$ and $700{ }^{\circ} \mathrm{C}$ temperatures, 1 and $2 \mathrm{~h}$ holding times, $n=6$

Remiantis Domingues et al. (2017) tyrimu, pušies žievès bioanglies išeiga $450{ }^{\circ} \mathrm{C}$ temperatūroje siekè $49,3 \%, \quad$ o $750{ }^{\circ} \mathrm{C}-38,9 \%$. Celiuliozès, hemiceliuliozès ir lignino kiekiai gali stipriai varijuoti tarp skirtingų žaliavų ir šie 
skirtumai gali lemti skirtumus tarp bioanglies išeigos ir savybių. Didelè bioanglies išeiga siejama su didesniu neorganinių junginių, esančių žaliavoje, kiekiu, kurị parodo palyginti didelis pelenų kiekis.

Didžiausiu peleningumu pasižymėjo K450-1 (31,9 \%), mažiausiu - PM4501 (0,54\%) (3.6 pav.). Lyginant medienos ir žievių peleningumus, žievių bioanglies peleningumas buvo 7-8 kartais didesnis, lyginant su medienos bioanglimi. Visų žaliavų atvejais peleningumas didejjo augant pirolizès temperatūrai nepriklausomai nuo kaitinimo laiko.

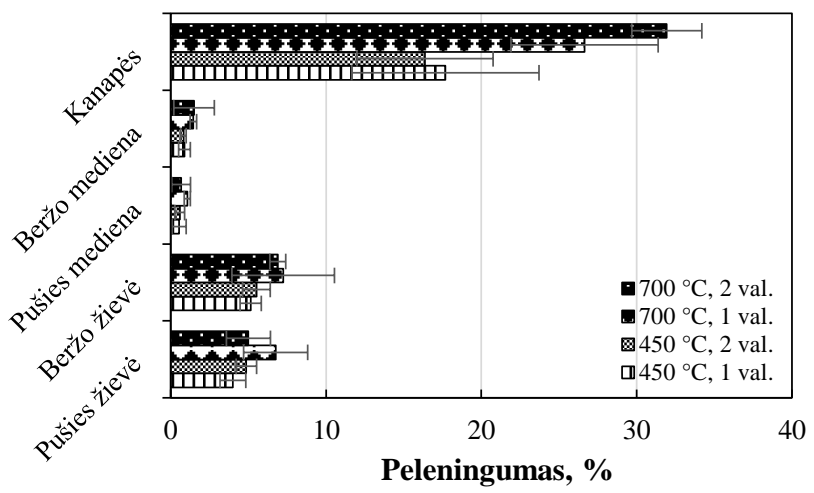

3.6 pav. Lignoceliuliozinès žaliavų bioanglies tipų, pagamintų 450 ir $700{ }^{\circ} \mathrm{C}$ temperatūrose bei esant 1 ir 2 val. kaitinimo laikui, peleningumas, $n=2$

Fig. 3.6. Ash content of lignocellulosic biochar types produced at 450 and $700{ }^{\circ} \mathrm{C}$ temperatures, 1 and $2 \mathrm{~h}$ holding times, $n=2$

Didelis kanapių bioanglies peleningumas gali sietis su didesniais neorganinių junginių ( $\mathrm{K}, \mathrm{P}, \mathrm{Ca}$ ir $\mathrm{Mg}$ ) kiekiais pradinèje žaliavoje. Panašiai didelis peleningumas buvo nustatytas ir kukurūzų bioanglyje (28 \%) (Peterson, Jackson, 2014). Mažas medienos bioanglies peleningumas gali sietis su mažais maistinių medžiagų kiekiais. Peleningumo didejjimas, augant temperatūrai, siejamas su mineralinių medžiagų koncentracijos didèjimu ir lignoceliuliozinès žaliavos destrukcine volatilizacija (Rafiq et al., 2016). Panašiai, atliekant kitą tyrimą, (Crombie et al., 2013) $450{ }^{\circ} \mathrm{C}$ pušies medienos bioanglis turejjo 2,9\% pelenų, o $650{ }^{\circ} \mathrm{C}-5,9 \%$.

Didžiausiu pH pasižymėjo BŽ700-1 (9,34), o mažiausiu - PM450-2 (5,41). Beveik visų žaliavų (išskyrus pušies medienos) bioanglies tipų pH siekẻ daugiau nei 7,5. Daugiau nei $2 \mathrm{pH}$ vienetų skirtumas nustatytas naudojant pušies medienos bioangli, kai esant $450{ }^{\circ} \mathrm{C}$ ji pasižymèjo vidutiniu rūgštingumu (5,41; PM450-2), o esant $700{ }^{\circ} \mathrm{C}$ - šarmingumu $(8,07$; PM700-2). Kaitinimo laikas turejjo įtakos 
reikšmingiems bioanglies $\mathrm{pH}$ skirtumams visų žaliavų atvejais, kuris buvo didžiausias naudojant pušies medieną $(p<0,01)$.

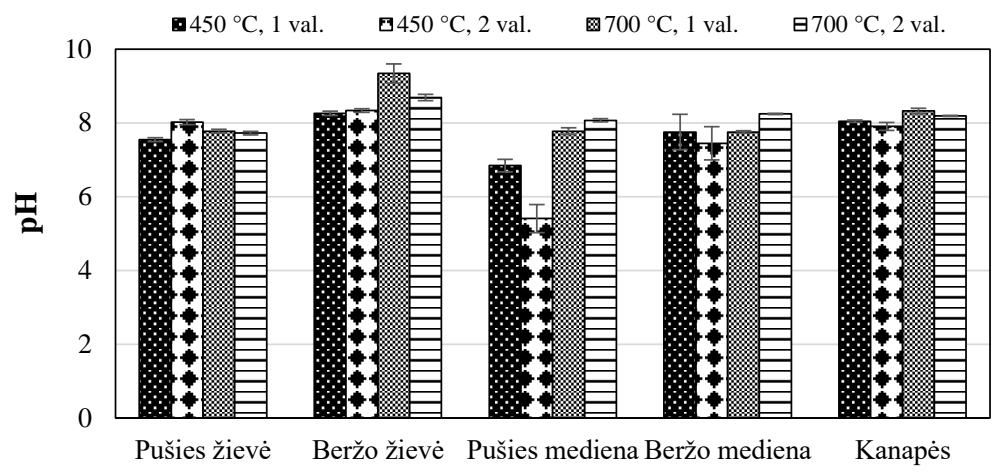

3.7 pav. Lignoceliuliozinès žaliavos bioanglies tipų, pagamintų 450 ir $700{ }^{\circ} \mathrm{C}$ temperatūrose bei esant 1 ir 2 val. kaitinimo laikui, $\mathrm{pH}, n=3$

Fig. 3.7. $\mathrm{pH}$ of lignocellulosic biochar types produced at 450 and $700{ }^{\circ} \mathrm{C}$ temperatures, 1 and $2 \mathrm{~h}$ holding times, $n=3$

Aukštatemperatūrès bioanglies $\mathrm{pH}$ stabilizacija siejama su organinių rūgštinių funkcinių grupių praradimu bei šarminių katijonų kiekio didèjimu, kurie savo ruožtu gali būti siejami su šarminiais junginiais (karbonatai, oksidai, hidroksidai) (Zhang, 2016). Didesnio šarmingumo bioanglis gali pagerinti dirvožemio kokybę dẻl tinkamos aplinkos dirvožemio mikroorganizmams sukūrimo. Pušies bioanglies $\left(450^{\circ} \mathrm{C}\right)$ rūgštingumas galimai siejasi su deguonies funkcinèmis grupėmis, kurios randamos organinèje medžiagoje.

Elektrinis laidis priklauso nuo druskų kiekio bioanglyje ir todèl gali būti naudojamas apskaičiuojant medžiagos druskingumą. Didžiausias elektrinis laidis buvo beržo žievès bioanglies $(0,55 \mathrm{mS} / \mathrm{cm} ; \mathrm{BŽ} 700-1)$, o mažiausias - beržo medienos $\left(0,041 \mathrm{mS} / \mathrm{cm} ; 450{ }^{\circ} \mathrm{C}, 2\right.$ val.). Beveik visų žaliavų atvejais (išskyrus pušies žievès) didèjant temperatūrai elektrinis laidis taip pat didèjo. Gautos didesnès elektrinio laidžio vertès beržo žievès ir kanapių bioanglies $\left(700^{\circ} \mathrm{C}\right)$ atvejais gali sietis su didesnèmis ištirpusios neorganinès anglies koncentracijomis (Domingues et al., 2017). Didesnị bioanglies elektrinị laidị, esant didesnei temperatūrai, galëjo lemti kondensuotų aromatinių žiedų sukelta dehidratacija kylant temperatūrai intervale nuo 600 iki $800^{\circ} \mathrm{C}$. Tai aiškinama aukštatemperatūrès bioanglies artima nuliui $\mathrm{H} / \mathrm{C}$ verte, kuri rodo, kad vyko dehidratacija. Tai galètų paaiškinti, kodèl $700{ }^{\circ} \mathrm{C}$ bioanglies elektrinis laidis buvo didesnis už žematemperatūrès $\left(450^{\circ} \mathrm{C}\right)$ bioanglies šiame tyrime. 


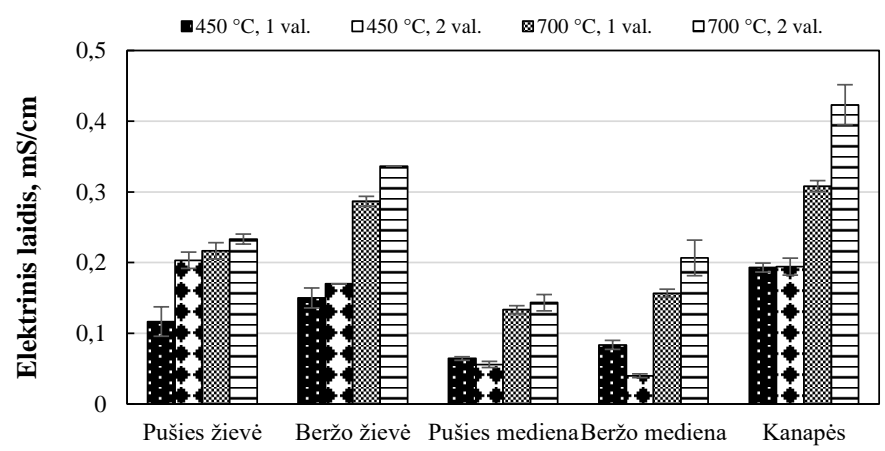

3.8 pav. Lignoceliuliozinès bioanglies tipu, pagamintų esant 450 ir $700{ }^{\circ} \mathrm{C}$ temperatūroms bei 1 ir 2 val. kaitinimo laikui, elektrinis laidis $(\mathrm{mS} / \mathrm{cm}), n=3$

Fig. 3.8. Electrical conductivity $(\mathrm{mS} / \mathrm{cm})$ of lignocellulosic biochar types produced at 450 and $700^{\circ} \mathrm{C}$ temperatures, 1 and $2 \mathrm{~h}$ holding times, $n=3$

Ištirpusios organinès anglies (IOA) kiekis visuose bioanglies tipuose varijavo nuo 1,88 iki $12,3 \mathrm{mg} / \mathrm{l}$ (3.9a pav.). Didžiausiu IOA kiekiu pasižymėjo kanapių bioanglis (12,3 mg/l; K450-2), mažiausiu - pušies žievès $(1,88 \mathrm{mg} / \mathrm{l}$; PŽ450-1). Medienos ir kanapių bioanglies tipai pasižymèjo IOA kiekio mažejimo tendencija augant temperatūrai. Tai rodo, kad vandenyje tirpi anglis suskaidoma arba ị bioanglies organinius junginius inkorporuojama pirolizès metu. Ištirpusios neorganinès anglies (INA) kiekis visuose bioanglies tipuose varijavo nuo 3,52 iki $71,3 \mathrm{mg} / \mathrm{l}$ (3.9 b pav.).
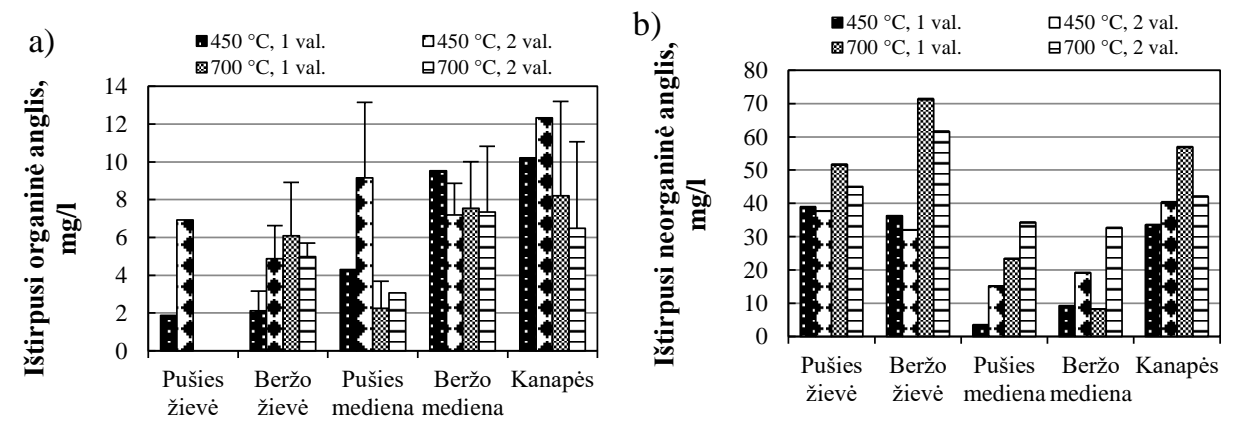

3.9 pav. Lignoceliuliozinės bioanglies tipų, pagamintų esant 450 ir $700{ }^{\circ} \mathrm{C}$ temperatūroms bei 1 ir 2 val. kaitinimo laikui ištirpusios anglies kiekiai $(\mathrm{mg} / \mathrm{l})$ :

a) organinès anglies kiekis; $\mathrm{b}$ ) neorganinès anglies kiekis, $n=3$

Fig. 3.9. Amounts of dissolved carbon ( $\mathrm{mg} / \mathrm{l})$ in lignocellulosic biochar types produced at 450 and $700^{\circ} \mathrm{C}$ temperatures, 1 and $2 \mathrm{~h}$ holding times: a) organic carbon content;

b) inorganic carbon content, $n=3$ 
Didžiausiu anglies kiekiu pasižymèjo pušies medienos bioanglis $(94,8 \%$; PM450-1), mažiausiu - pušies žievès (PŽ450-2; 66,5 \%) (3.10 pav.). Panašiai Conz et al. (2017) nustaté, kad pjuvenų bioanglies $\mathrm{C}$ kiekis varijavo plačiame intervale priklausomai nuo temperatūros (51-77\%). Didžiausiu O kiekiu pasižymèjo pušies žievès bioanglis (PŽ450-2, 25,1\%), mažiausiu - beržo medienos (BM700-2, 3,58 \%). Didèjant temperatūrai $\mathrm{O}$ ir $\mathrm{H}$ kiekiai mažèjo beveik visuose bioanglies tipuose. Didžiausias $\mathrm{O}$ kiekio sumažèjimas didejjant temperatūrai pastebètas pušies žievès bioanglies atveju (7,61 \%). Tai galima aiškinti žaliavos paviršiaus $-\mathrm{OH}$ funkcinių grupių praradimu dèl dehidratacijos bei $\mathrm{O}$ ir $\mathrm{H}$ atomų paradimu dèl struktūros degradacijos (Pituya et al., 2016). H kiekis didejjant temperatūrai mažèjo visuose bioanglies tipuose (išskyrus kanapių) ir tai geriausiai atsispindèjo kaitinant 2 val. İvairūs bioanglies tipai pasižymèjo nedideliais $\mathrm{N}$ kiekiais (nuo 0,52 iki $0,01 \%$ ).

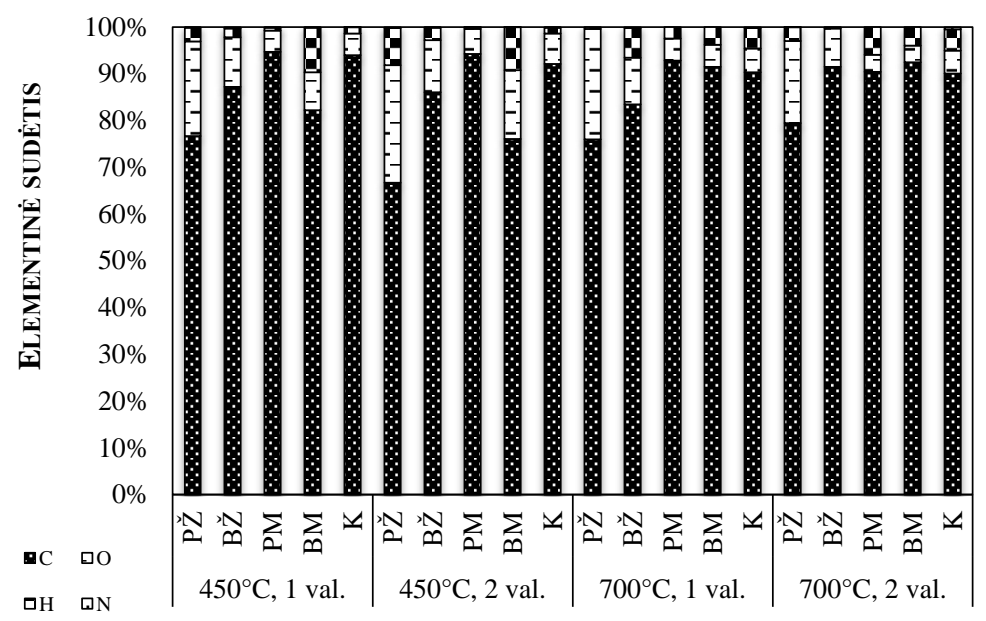

3.10 pav. Lignoceliuliozinès bioanglies tipu elementinè (C, H, N, O) sudètis, \% Fig. 3.10. Elemental composition (C, H, N, O) of lignocellulosic biochar types, $\%$

Didžiausia vandens laikomaja geba (VSG) pasižymèjo kanapių bioanglis (912\%; K700-2), o mažiausia - beržo žievès (124\%; BŽ450-1) (3.11 pav.). Didesnis vandens sulaikymas naudojant kanapių bioanglị galètų būti aiškinamas didesniu bioanglies polingumu, hidrofiliškumu ir mikroporingumu, kuris reikalingas fiziniam vandens sulaikymui. Paprastai iš javų atliekų gautos bioanglies poringumas yra didesnis, lyginant su medienos bioanglimi, todèl prieinamo vandens laikomoji geba yra didesnè, lyginant su medienos bioanglimi (Omondi et al., 2016). 


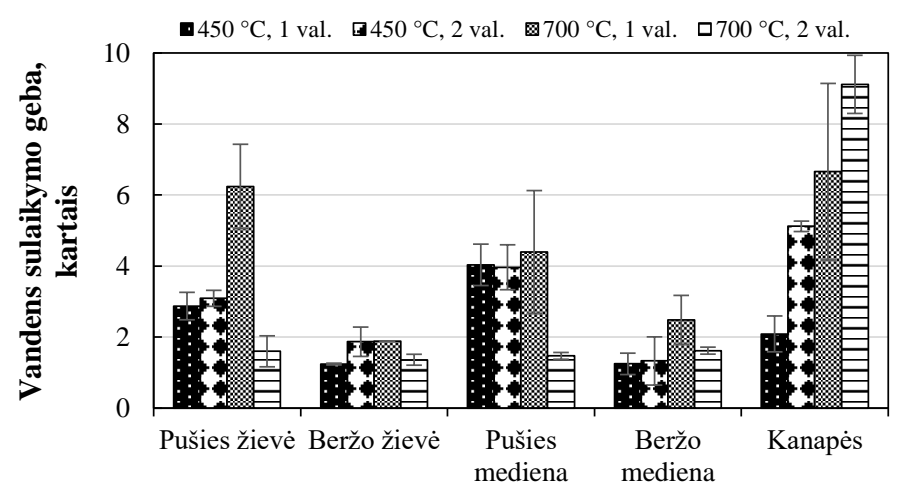

3.11 pav. Lignoceliuliozinès bioanglies tipų, pagamintų esant 450 ir $700{ }^{\circ} \mathrm{C}$ temperatūrose bei 1 ir 2 val. kaitinimo laikui, vandens laikomoji geba (\%), $n=3$

Fig. 3.11. Water holding capacity (\%) of lignocellulosic biochar types produced at 450 and $700^{\circ} \mathrm{C}$ temperatures, 1 and $2 \mathrm{~h}$ holding times, $n=3$

Remiantis SEM analize, pušies žievès bioanglies $\left(450^{\circ} \mathrm{C}, 2\right.$ val.) vidutinis porų skersmuo siekè $6,21 \mu \mathrm{m}$, beržo žievès bioanglies $-8,36 \mu \mathrm{m}$ (3.12 a pav.). Pušies žievès bioanglies, pagamintos aukštesnèje temperatūroje $\left(750^{\circ} \mathrm{C}, 2\right.$ val.), vidutinis porų skersmuo siekè $8,24 \mu \mathrm{m}$, o aukštatemperatūrès beržo žievès bioanglies $-7,5 \mu \mathrm{m}$ (3.12 c pav.). Iš $3.12 \mathrm{~d}$ paveikslo matyti, kad beržo žievès bioanglis $750{ }^{\circ} \mathrm{C}$ p temperatūroje pasižymėjo nevisa porų struktūra dèl aukštesnès temperatūros. Ant bioanglies paviršiaus matyti smulkios kietos dalelès, kurių susidarymą lèmé pelenų akumuliacija aukštoje temperatūroje. Bioanglies mikrostruktūra reikšmingai nepakito po temperatūros poveikio, tačiau didesnis skirtumas matyti tarp skirtingų bioanglies žaliavų porų formų. Matyti, kad pušies žievès bioanglis, paveikta skirtingų temperatūrų, pasižymèjo gerai išsivysčiusia porų struktūra su cilindrinių vamzdelių formos poromis. Beržo žievės bioanglies struktūra pasižymèjo ovalios formos poromis ir turèjo daug mikrodalelių su mikroporomis. Didèjant kaitinimo temperatūrai, galima stebėti labiau išsivysčiusios bioanglies struktūros tendenciją (Baltrènas et al., 2015). Didesnis porų skaičius susidarè esant didesnei pirolizès temperatūrai visų bioanglies tipų atvejais, todèl galima teigti, kad morfologiniai pokyčiai, atsirandantys bioanglies tipuose, tam tikru lygiu vyksta formuojantis bioanglies reakcijoms (Liang et al., 2016). Pirolizès temperatūra turi reikšmingą ịtaką bioanglies porų struktūrai. Tarp 200 ir $500{ }^{\circ} \mathrm{C}$ reikšmingas lakiosios medžiagos kiekio pasišalinimas lemia atsiverusių porų susidarymą. Cheminių jungčių terminis skaidymas ir kai kurių junginių tirpimas gali nutraukti chemines jungtis, todèl originalioje medžiagos struktūroje susidaro daugiau porų (Liang et al., 2016). 
a)

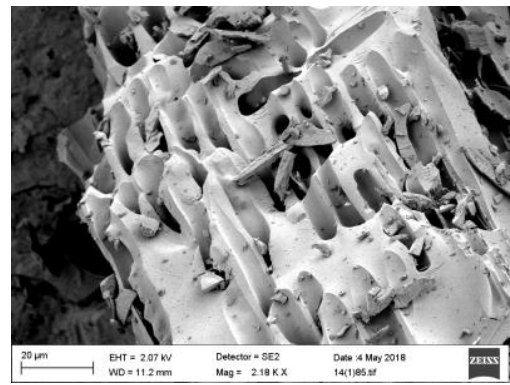

c)

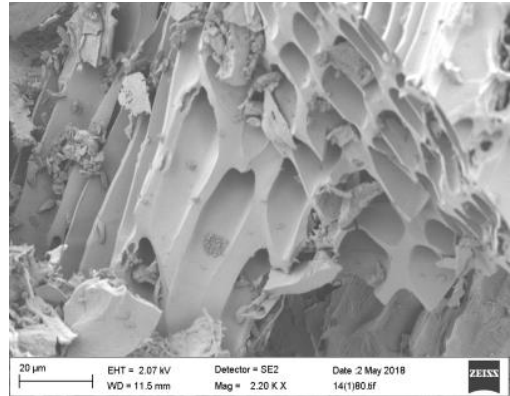

b)

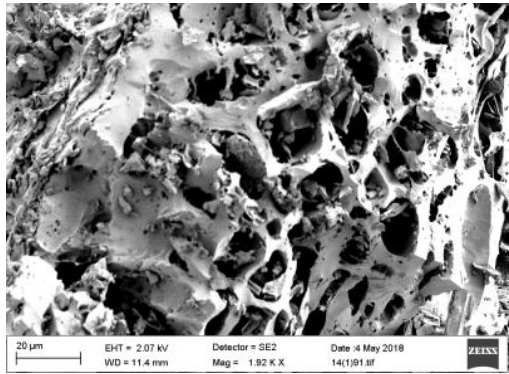

d)

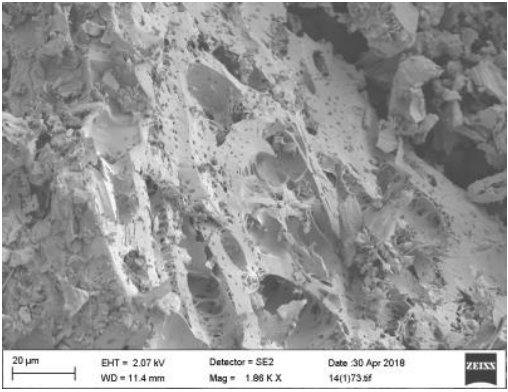

3.12 pav. Lignoceliuliozinès bioanglies morfologiniai vaizdai: a) pušies žievès $\left(450{ }^{\circ} \mathrm{C}\right)$;

b) beržo žievès $\left(450^{\circ} \mathrm{C}\right)$; c) pušies žievès $\left(750^{\circ} \mathrm{C}\right)$; d) beržo žievès $\left(750^{\circ} \mathrm{C}\right), n=3$

Fig. 3.12. Morphological images of lignocellulosic biochar: a) pine bark $\left(450^{\circ} \mathrm{C}\right)$;

b) birch bark $\left(450^{\circ} \mathrm{C}\right)$; (c) pine bark $\left(750^{\circ} \mathrm{C}\right)$; d) birch bark $\left(750^{\circ} \mathrm{C}\right), n=3$

Kur kas didesniu SPP pasižymėjo $700{ }^{\circ} \mathrm{C}$ bioanglies tipai (3.1 lentelè). Pušies žievès bioanglies $\left(750^{\circ} \mathrm{C}\right)$ SPP didejo 12,4 karto, lyginant su $450{ }^{\circ} \mathrm{C}$ bioanglimi, beržo žievès - 4,7, kanapių - 9,9 karto. Taip pat stebėtas bendrojo ir mikroporų tūrio didejjimas, kylant temperatūrai visų žaliavų atvejais (pušies žievès $-8,3$ ir 200 kartų, beržo žievès - 22 ir 48 kartus, kanapių - 4,8 ir 9,5 karto). Didèjant temperatūrai porų skersmenys mažèjo visų žaliavų bioanglies atvejais.

3.1 lentelè. Pušies ir beržo žievès bei kanapių bioanglies $\mathrm{N}_{2}$ adsorbcijos rezultatai Table 3.1. $\mathrm{N}_{2}$ adsorption results for pine bark, birch bark, and hemp biochar

\begin{tabular}{|l|l|l|l|}
\hline \multicolumn{1}{|c|}{ Bioanglies tipas } & $\begin{array}{c}\text { BET savitasis } \\
\text { paviršiaus plotas, } \\
\mathrm{m}^{2} / \mathrm{g}\end{array}$ & $\begin{array}{c}\text { Porų tūis, } \mathrm{mm}^{3} / \mathrm{g} \\
\text { (bendrasis/mikroporų) }\end{array}$ & Porų dydis, $\mathrm{nm}$ \\
\hline Pušies žievė $\left(450^{\circ} \mathrm{C}\right)$ & 33,9 & $0,03 / 0,001$ & 3,84 \\
\hline Pušies žievè $\left(700^{\circ} \mathrm{C}\right)$ & 421 & $0,25 / 0,2$ & 2,41 \\
\hline Beržo žieve $\left(450^{\circ} \mathrm{C}\right)$ & 80,3 & $0,01 / 0,004$ & 5,73 \\
\hline
\end{tabular}


3.1 lentelès pabaiga

\begin{tabular}{|l|l|l|l|}
\hline \multicolumn{1}{|c|}{ Bioanglies tipas } & $\begin{array}{c}\text { BET savitasis } \\
\text { paviršiaus plotas, } \\
\mathrm{m}^{2} / \mathrm{g}\end{array}$ & $\begin{array}{c}\text { Porų tūris, } \mathrm{mm}^{3} / \mathrm{g} \\
\text { (bendrasis/mikroporu) }\end{array}$ & Porų dydis, nm \\
\hline Beržo žievè $\left(700^{\circ} \mathrm{C}\right)$ & 381 & $0,22 / 0,19$ & 2,35 \\
\hline Kanapès $\left(450^{\circ} \mathrm{C}\right)$ & 39,4 & $0,05 / 0,02$ & 4,88 \\
\hline Kanapès $\left(700^{\circ} \mathrm{C}\right)$ & 392 & $0,24 / 0,19$ & 2,44 \\
\hline
\end{tabular}

Taigi, esant didesnei temperatūrai $\left(700^{\circ} \mathrm{C}\right)$ ir laikui (2 val.) bioanglies savitasis paviršiaus plotas, bendrasis ir mikroporu tūris, porų išsivystymas, peleningumas, $\mathrm{pH}, \mathrm{C}$ kiekis taip pat buvo didesni, o išeiga, $\mathrm{N}, \mathrm{O}$ ir $\mathrm{H}$ kiekiai mažesni dèl pirolizès lakiưjų junginių išsiskyrimo. Bioanglies drèkumas taip pat buvo didesnis esant aukštesnei temperatūrai ir kaitinimo laikui. Taigi didesnị bioanglies drèkumą galima sieti su geriau išsivysčiusiomis jos struktūrinèmis savybèmis, kurias lemia aukštesnè temperatūra $\left(>500^{\circ} \mathrm{C}\right)$ ir ilgesnis kaitinimo laikas (>2 val.).

Tyrimų tikslas - ịvertinti temperatūros poveikị bioanglies fizikinèms ir cheminèms savybèms, prognozuoti jos drèkumą bei vandens laikomają gebą remiantis kitomis savybemis. Bioanglies išeiga pavaizduota 3.13 paveiksle. Bioanglies išeiga mažejo didejjant temperatūrai. Pušies žievé pasižymėjo didžiausia išeiga (52,6 \%), lyginant su kitais žaliavų tipais. Kanapès pasižymėjo mažiausia išeiga (11,2\%). Bioanglies išeigos mažejimas, didejjant temperatūrai, siejamas su pirmine termine biomasès degradacija (Rafiq et al., 2016).

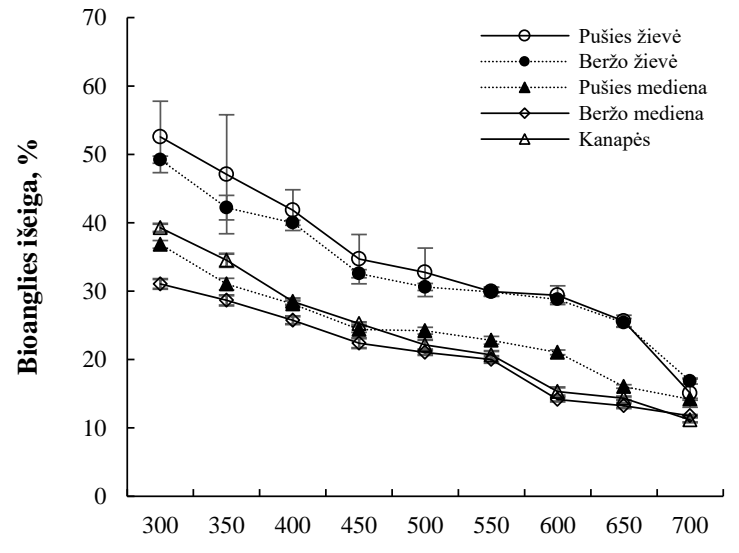

Bioanglies gamybos temperatūra, ${ }^{\circ} \mathrm{C}$

3.13 pav. Lignoceliuliozinès bioanglies $\left(300-700{ }^{\circ} \mathrm{C}\right)$ išeiga $(\%), n=2$

Fig. 3.13. Yield $(\%)$ of lignocellulosic biochar $\left(300-700^{\circ} \mathrm{C}\right), n=2$ 
Bioanglies peleningumas didejjo augant temperatūrai nuo $300{ }^{\circ} \mathrm{C}$ iki $700{ }^{\circ} \mathrm{C}$ : pušies žievès - nuo 3,22 \% iki 5,57\%; beržo žievès - 2,16-6,89\%; pušies medienos - 0,58-3,99 \%; beržo medienos - 0,82-2,77 \%; kanapių - 2,95-32,1 \% (3.14 pav.). Didžiausias peleningumas buvo kanapių bioanglies $(32,1 \%$; K7002). Progresyvus pelenų didejjimas augant temperatūrai siejamas su neorganinių junginių kiekio didejjimu bioanglyje (Zhao et al., 2017).

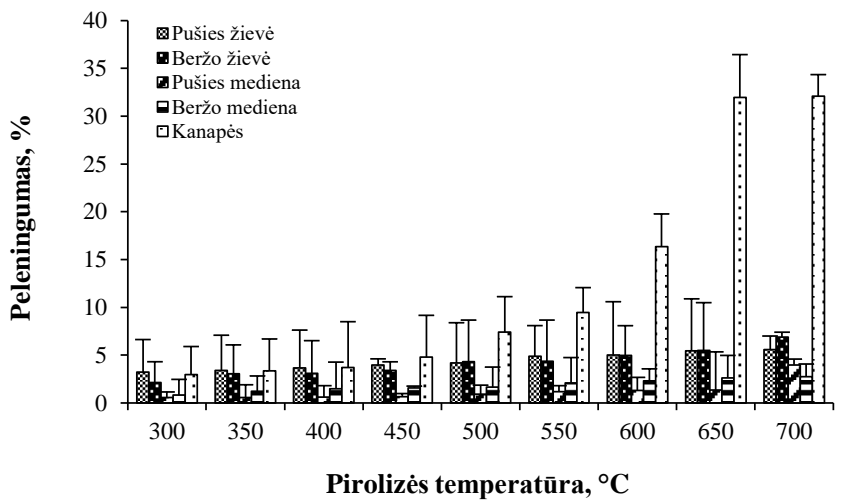

3.14 pav. Lignoceliuliozinès bioanglies $\left(300-700^{\circ} \mathrm{C}\right)$ peleningumas $(\%), n=3$

Fig. 3.14. Ash content (\%) of lignocellulosic biochar $\left(300-700^{\circ} \mathrm{C}\right), n=3$

Bioanglies tipų $\mathrm{pH}$ didèjo augant temperatūrai (3.15 pav.). Pušies žievès bioanglies pH didejjo nuo 5,05 iki 8,32, beržo žievès - nuo 6,39 iki 8,69, pušies medienos - nuo 6,48 iki 8,22, beržo medienos - nuo 6,27 iki 9,06, kanapių - nuo 6,7 iki 8,41. Bioanglies tipų $\mathrm{pH}$ didejjimas augant temperatūrai siejamas su didesniu peleningumu bei $\mathrm{Ca}, \mathrm{K}$ ir Mg druskų hidrolize (Nwajiaku et al., 2018).

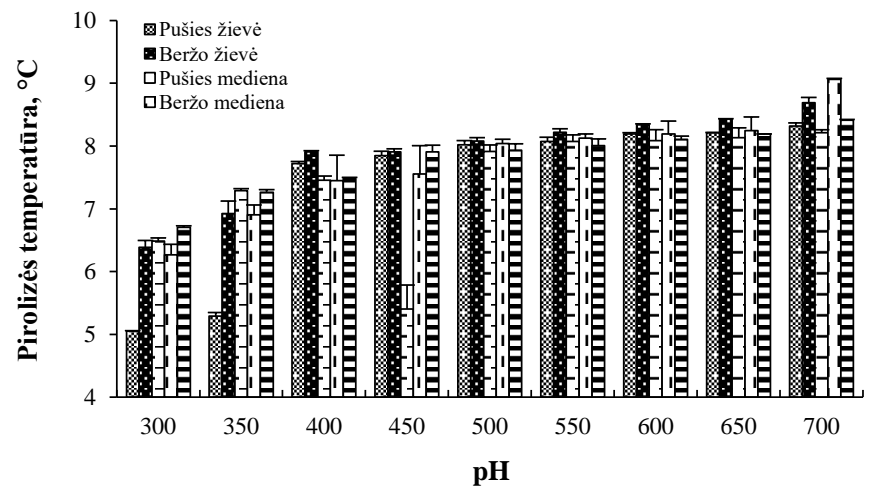

3.15 pav. Lignoceliuliozinès bioanglies $\left(300-700{ }^{\circ} \mathrm{C}\right) \mathrm{pH}, n=3$

Fig. 3.15. $\mathrm{pH}$ of lignocellulosic biochar $\left(300-700^{\circ} \mathrm{C}\right), n=3$ 
Bioanglies elektrinis laidis didejo augant temperatūrai nuo $300{ }^{\circ} \mathrm{C}$ iki $700{ }^{\circ} \mathrm{C}$ visų žaliavų atvejais, kuris pušies žievès atveju kito nuo 0,05 iki $0,36 \mathrm{mS} / \mathrm{cm}$, beržo žievès $-0,05-0,36 \mathrm{mS} / \mathrm{cm}$, pušies medienos - 0,06-0,3 $\mathrm{mS} / \mathrm{cm}$, beržo medienos - 0,04-0,37 $\mathrm{mS} / \mathrm{cm}$ ir kanapių - 0,19-0,42 $\mathrm{mS} / \mathrm{cm}$ (3.16 pav.). Nemedienos biomasè (kanapès) pasižymėjo nuo 3,8 iki 1,16 karto didesniu elektriniu laidžiu lyginant su medienos žaliavomis. Kanapių didžiausią elektrinị laidị galëjo lemti tirpių mineralų buvimas. Elektrinis laidis didejjo augant temperatūrai dẻl lakiujjų junginių praradimo, o tai lemia santykinai didesnę druskų koncentraciją pelenų frakcijoje (Nwajiaku et al., 2018).

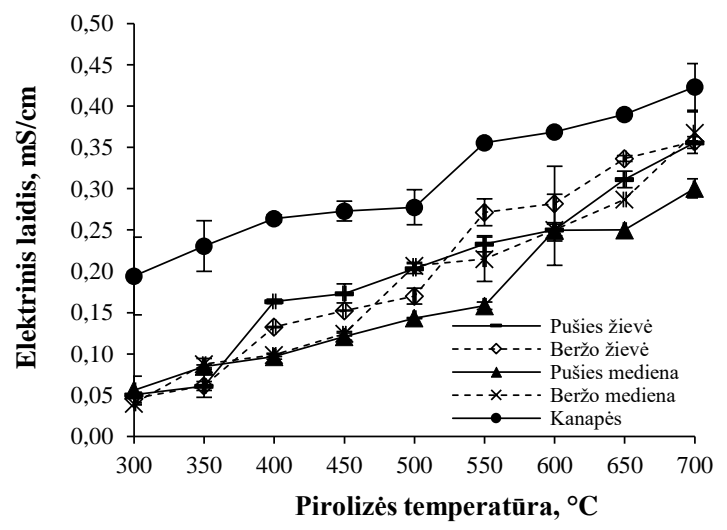

3.16 pav. Lignoceliuliozinès bioanglies $\left(300-700^{\circ} \mathrm{C}\right)$ elektrinis laidis $(\mathrm{mS} / \mathrm{cm}), n=3$ Fig. 3.16. Electrical conductivity $(\mathrm{mS} / \mathrm{cm})$ of lignocellulosic biochar $\left(300-700^{\circ} \mathrm{C}\right), n=3$

Lignoceliuliozinès bioanglies elementiniai $(\mathrm{C}, \mathrm{H}, \mathrm{N}, \mathrm{O})$ kiekiai ir atominiai santykiai pateikti 3.2 lentelejje. Visų žaliavų atvejais matyti, kad, didejjant temperatūrai $\left(300-700{ }^{\circ} \mathrm{C}\right), \mathrm{C}$ kiekis taip pat didejo, o H, O ir N kiekiai mažèjo. $\mathrm{C}$ kiekiai kito plačiame intervale ir jis geriausiai atsispindèjo naudojant pušies žievès bioangli (47,5-85,7\%). Visų žaliavų atvejais $\mathrm{O}, \mathrm{H}$ ir $\mathrm{N}$ koncentracijos mažèjo. Labiausiai sumažejo pušies medienos bioanglies O kiekis (75\%). Beržo žievès ir pušies medienos bioanglies tipai pasižymèjo 100 \% H kiekio sumažejjimu kylant temperatūrai. Visų žaliavų atveju pirolizès temperatūra lèmė visišką (100 \%) N praradimą. Panašiai Conz et al. (2017) nustatè, kad medienos pjuvenu bioanglies tipuose $\mathrm{C}$ kiekis kito didžiausiame intervale (51-77\%) priklausomai nuo pirolizès temperatūros. $\mathrm{C}$ kiekio didejjimas siejamas su deguonies turinčių funkcinių grupių praradimu dèl dehidratacijos ir dekarboksilizacijos reakcijų. Kuo aromatingesné susiformuoja struktūra, tuo atsparesnè mikrobiologinei degradacijai yra bioanglis. 
3.2 lentelè. Bioanglies, pagamintos iš skirtingų žaliavų $300-700{ }^{\circ} \mathrm{C}$ temperatūrose, elementinè sudètis bei atominiai santykiai, $n=3$

Table 3.2. Elemental composition and atomic ratios of biochar produced from different feedstocks at $300-700^{\circ} \mathrm{C}$ temperatures, $n=3$

\begin{tabular}{|c|c|c|c|c|c|c|c|}
\hline \multirow{2}{*}{$\begin{array}{c}\text { Žaliavos } \\
\text { tipas }\end{array}$} & \multirow{2}{*}{$\begin{array}{c}\text { Temperatūra, } \\
{ }^{\circ} \mathrm{C}\end{array}$} & \multicolumn{4}{|c|}{ Elementinè sudètis, $\%$} & \multicolumn{2}{|c|}{$\begin{array}{l}\text { Atominiai } \\
\text { santykiai }\end{array}$} \\
\hline & & $\mathrm{C}$ & $\mathrm{H}$ & $\mathrm{N}$ & $\mathrm{O}$ & $\mathrm{O} / \mathrm{C}$ & $\mathrm{H} / \mathrm{C}$ \\
\hline \multirow{9}{*}{$\begin{array}{l}\text { Pušies } \\
\text { žievè }\end{array}$} & 300 & 47,5 & 32,2 & 0,20 & 20,1 & 7,20 & 0,28 \\
\hline & 350 & 71,1 & 13,5 & 0,20 & 14,4 & 2,27 & 0,15 \\
\hline & 400 & 72,3 & 12,4 & 0,19 & 14,2 & 2,04 & 0,15 \\
\hline & 450 & 77,5 & 8,43 & 0,19 & 13,8 & 1,27 & 0,13 \\
\hline & 500 & 79,9 & 7,29 & 0,15 & 12,7 & 1,09 & 0,12 \\
\hline & 550 & 81,8 & 7,24 & 0,14 & 10,4 & 1,06 & 0,10 \\
\hline & 600 & 83,4 & 6,23 & 0,04 & 9,08 & 0,89 & 0,08 \\
\hline & 650 & 84,9 & 5,98 & - & 7,56 & 0,84 & 0,07 \\
\hline & 700 & 85,7 & 3,28 & - & 5,49 & 0,46 & 0,05 \\
\hline \multirow{9}{*}{$\begin{array}{l}\text { Beržo } \\
\text { žievė }\end{array}$} & 300 & 71,3 & 12,9 & 0,84 & 14,9 & 1,94 & 0,14 \\
\hline & 350 & 73,8 & 11,6 & 0,36 & 14,2 & 1,72 & 0,13 \\
\hline & 400 & 80,2 & 8,57 & 0,29 & 10,9 & 1,23 & 0,10 \\
\hline & 450 & 82,7 & 7,05 & 0,27 & 9,97 & 1,01 & 0,09 \\
\hline & 500 & 85,7 & 5,79 & 0,18 & 8,32 & 0,80 & 0,07 \\
\hline & 550 & 87,8 & 3,96 & 0,09 & 8,12 & 0,53 & 0,07 \\
\hline & 600 & 90,7 & 2,19 & - & 7,12 & 0,29 & 0,06 \\
\hline & 650 & 91,8 & 0,48 & - & 5,89 & 0,06 & 0,05 \\
\hline & 700 & 92,3 & 0,00 & - & 5,14 & 0,00 & 0,04 \\
\hline \multirow{7}{*}{$\begin{array}{l}\text { Pušies } \\
\text { mediena }\end{array}$} & 300 & 71,7 & 13,3 & 0,29 & 14,7 & 0,14 & 2,07 \\
\hline & 350 & 76,47 & 11,4 & 0,27 & 11,8 & 0,11 & 1,69 \\
\hline & 400 & 82,3 & 7,04 & 0,22 & 10,4 & 0,09 & 1,02 \\
\hline & 450 & 84,3 & 5,93 & 0,03 & 9,70 & 0,09 & 0,84 \\
\hline & 500 & 84,8 & 5,67 & 0,02 & 8,52 & 0,08 & 0,80 \\
\hline & 550 & 85,8 & 3,75 & - & 8,07 & 0,07 & 0,52 \\
\hline & 600 & 89,6 & 2,81 & - & 7,60 & 0,06 & 0,37 \\
\hline
\end{tabular}


3.2 lentelès pabaiga

\begin{tabular}{|c|c|c|c|c|c|c|c|}
\hline \multirow{2}{*}{$\begin{array}{c}\text { Žaliavos } \\
\text { tipas }\end{array}$} & \multirow{2}{*}{$\begin{array}{c}\text { Temperatūra, } \\
{ }^{\circ} \mathrm{C}\end{array}$} & \multicolumn{4}{|c|}{ Elementinè sudètis, $\%$} & \multicolumn{2}{|c|}{$\begin{array}{l}\text { Atominiai } \\
\text { santykiai }\end{array}$} \\
\hline & & $\mathrm{C}$ & $\mathrm{H}$ & $\mathrm{N}$ & $\mathrm{O}$ & $\mathrm{C}$ & $\mathrm{H}$ \\
\hline \multirow{2}{*}{$\begin{array}{l}\text { Pušies } \\
\text { mediena }\end{array}$} & 650 & 90,4 & 0,46 & - & 7,43 & 0,06 & 0,06 \\
\hline & 700 & 91,7 & 0,00 & - & 3,68 & 0,03 & 0,00 \\
\hline \multirow{9}{*}{$\begin{array}{l}\text { Beržo } \\
\text { mediena }\end{array}$} & 300 & 71,9 & 14,2 & 0,13 & 13,8 & 0,13 & 2,14 \\
\hline & 350 & 76,6 & 12,1 & 0,08 & 11,2 & 0,11 & 1,82 \\
\hline & 400 & 79,3 & 9,59 & 0,07 & 11,1 & 0,10 & 1,41 \\
\hline & 450 & 82,5 & 8,09 & 0,03 & 9,35 & 0,08 & 1,16 \\
\hline & 500 & 83,7 & 6,92 & 0,01 & 8,96 & 0,08 & 0,99 \\
\hline & 550 & 85,8 & 5,70 & - & 8,53 & 0,07 & 0,79 \\
\hline & 600 & 86,3 & 5,00 & - & 8,04 & 0,07 & 0,69 \\
\hline & 650 & 90,3 & 4,46 & - & 5,20 & 0,04 & 0,58 \\
\hline & 700 & 91,3 & 3,72 & - & 4,79 & 0,04 & 0,49 \\
\hline \multirow[t]{9}{*}{ Kanapès } & 300 & 70,6 & 15,2 & 0,52 & 13,7 & 0,14 & 2,40 \\
\hline & 350 & 73,7 & 12,9 & 0,21 & 13,1 & 0,12 & 1,96 \\
\hline & 400 & 79,7 & 10,6 & 0,21 & 9,47 & 0,09 & 1,53 \\
\hline & 450 & 82,9 & 7,77 & 0,19 & 8,09 & 0,07 & 1,12 \\
\hline & 500 & 84,9 & 7,61 & 0,18 & 7,29 & 0,06 & 1,05 \\
\hline & 550 & 86,7 & 6,55 & 0,12 & 6,64 & 0,06 & 0,89 \\
\hline & 600 & 88,3 & 5,20 & - & 6,50 & 0,06 & 0,70 \\
\hline & 650 & 89,2 & 4,29 & - & 6,49 & 0,05 & 0,57 \\
\hline & 700 & 91,9 & 1,44 & - & 4,93 & 0,04 & 0,19 \\
\hline
\end{tabular}

Bioanglies atominiai $\mathrm{O} / \mathrm{C}$ ir $\mathrm{H} / \mathrm{C}$ santykiai pateikti Van Krevelen diagramoje, kurie rodo aiškius skirtumus tarp skirtingų temperatūrų bioanglies (3.17 pav.). Kuo jie mažesni, tuo didesni $\mathrm{O}$ ir $\mathrm{H}$ paradimai kaitinimo metu. Visų žaliavų bioanglies tipai pasižymejo dideliais procentiniais $\mathrm{O} / \mathrm{C}$ ir $\mathrm{H} / \mathrm{C}$ santykių sumažèjimais kylant temperatūrai nuo 300 iki $700{ }^{\circ} \mathrm{C}$. Procentinis $\mathrm{O} / \mathrm{C}$ santykių mažèjimas rikiuojasi tokia tvarka: pušies žievè $(84,9 \%)>$ pušies mediena $(80,5 \%)>$ beržo žievè $(73,4 \%)>$ kanapès $(73,3 \%)>$ beržo mediena $(71,4 \%)$. Procentinis H/C santykių mažèjimas rikiuojasi tokia tvarka: beržo žievè (100 \%) 
$>$ pušies mediena $(100 \%)>$ pušies žievè $(94,4 \%)>$ kanapès $(92,7 \%)>$ beržo mediena (79,4 \%). Polines funkcines grupes parodo aukštesni O/C santykiai, t. y. didelis $\mathrm{O} / \mathrm{C}$ santykis rodo žemą bioanglies karbonizacijos laipsnị ir mažesnị stabilumą degradacijai dirvožemyje, bet didesnị reaktingumą. $\mathrm{H} / \mathrm{C}$ santykis turètų būti mažesnis nei 0,6, o $\mathrm{O} / \mathrm{C}$ santykis mažesnis nei 0,4 bioanglies atveju (EBC, 2012). Visi tirti bioanglies tipai turëjo $\mathrm{O} / \mathrm{C}$ santykị, mažesni nei 0,4 ir aukštatemperatūriai $\left(550-700{ }^{\circ} \mathrm{C}\right)$ bioanglies tipai turejjo $\mathrm{H} / \mathrm{C}$ santykị, mažesnị nei 0,6. Zhang et al. (2019) tyrime mažèjantys pušies spyglių bioanglies $\mathrm{H} / \mathrm{C}$ ir $\mathrm{O} / \mathrm{C}$ santykiai siejosi su didesniu aromatingumu ir mažesniu polingumu.

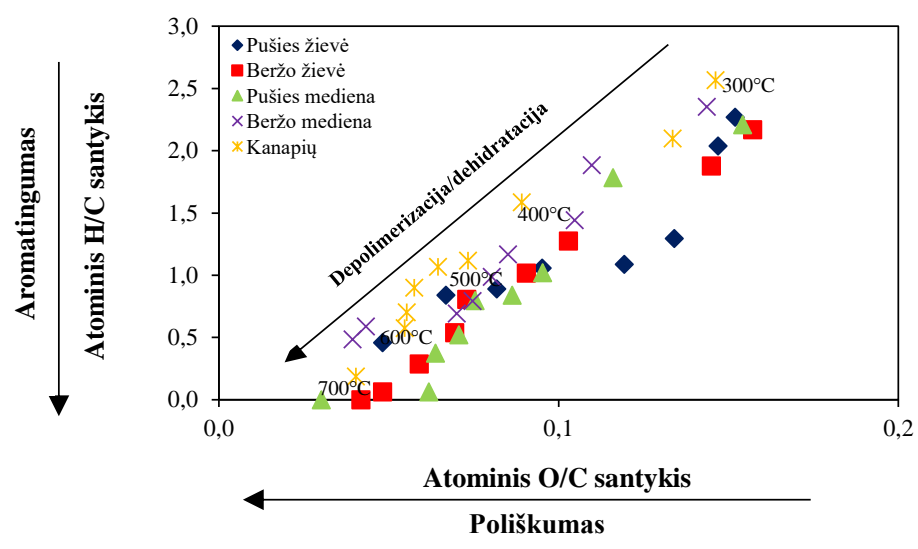

3.17 pav. $\mathrm{O} / \mathrm{C}$ ir $\mathrm{H} / \mathrm{C}$ santykiai Van Krevelen diagramoje

Fig. 3.17. $\mathrm{O} / \mathrm{C}$ and $\mathrm{H} / \mathrm{C}$ ratios in Van Krevelen diagram

Remiantis FTIR rezultatais, visų žaliavų bioanglies tipai pasižymėjo aminų funkcinėmis grupèmis $\left(3300-3500 \mathrm{~cm}^{-1}\right)$, alkanų $(\mathrm{C}-\mathrm{H})\left(2850-3000 \mathrm{~cm}^{-1}\right)$, rūgštinèmis $\left(1680-1700 \mathrm{~cm}^{-1} ; 1700-1730 \mathrm{~cm}^{-1} ; 1715-1740 \mathrm{~cm}^{-1}\right)$, aromatinèmis $\mathrm{C}=\mathrm{C}\left(1400-1600 \mathrm{~cm}^{-1} ; 1550-1640 \mathrm{~cm}^{-1}\right)$, anhidridinemis $\left(1150-1350 \mathrm{~cm}^{-1}\right)$ ir aromatinèmis $\mathrm{C}-\mathrm{H}\left(880-900 \mathrm{~cm}^{-1} ; 790-840 \mathrm{~cm}^{-1} ; 750-810 \mathrm{~cm}^{-1}\right)$ (3.18 pav.). Alkoholinių O-H funkcinių grupių (3500-3700 $\mathrm{cm}^{-1}$ ) turèjo visi bioanglies tipai, išskyrus beržo žievès. Azoto funkcinių grupių $\left(1300-1390 \mathrm{~cm}^{-1}\right)$ turèjo tik beržo žievès bioanglis, alkoksinių funkcinių grupių $\left(1000-1260 \mathrm{~cm}^{-1}\right)-$ tik pušies žievès, o alkinų $\mathrm{C}-\mathrm{H}$ funkcinių grupių $\left(620 \mathrm{~cm}^{-1}\right)$ - tik kanapių. $300{ }^{\circ} \mathrm{C}$ bioanglies tipai turëjo nedidelị absorbcijos piką ties $2850 \mathrm{~cm}^{-1}$, tai rodo alifatines funkcines grupes. Mažas žematemperatūrių $\left(<500^{\circ} \mathrm{C}\right)$ bioanglies tipų drèkumas siejamas su alifatinèmis funkcinėmis grupèmis, kurios garuoja tik aukštose temperatūrose. Yuan et al. (2019) parodè, kad žemose temperatūrose dominavo organinès ir neorganinès funkcinès grupès, kaip $\mathrm{kad}-\mathrm{OH}, \mathrm{C}=\mathrm{O}, \mathrm{C}=\mathrm{C}$ ir $\mathrm{C}-\mathrm{O}$, o temperatūrai didèjant organinių funkcinių grupių mažèjo. 

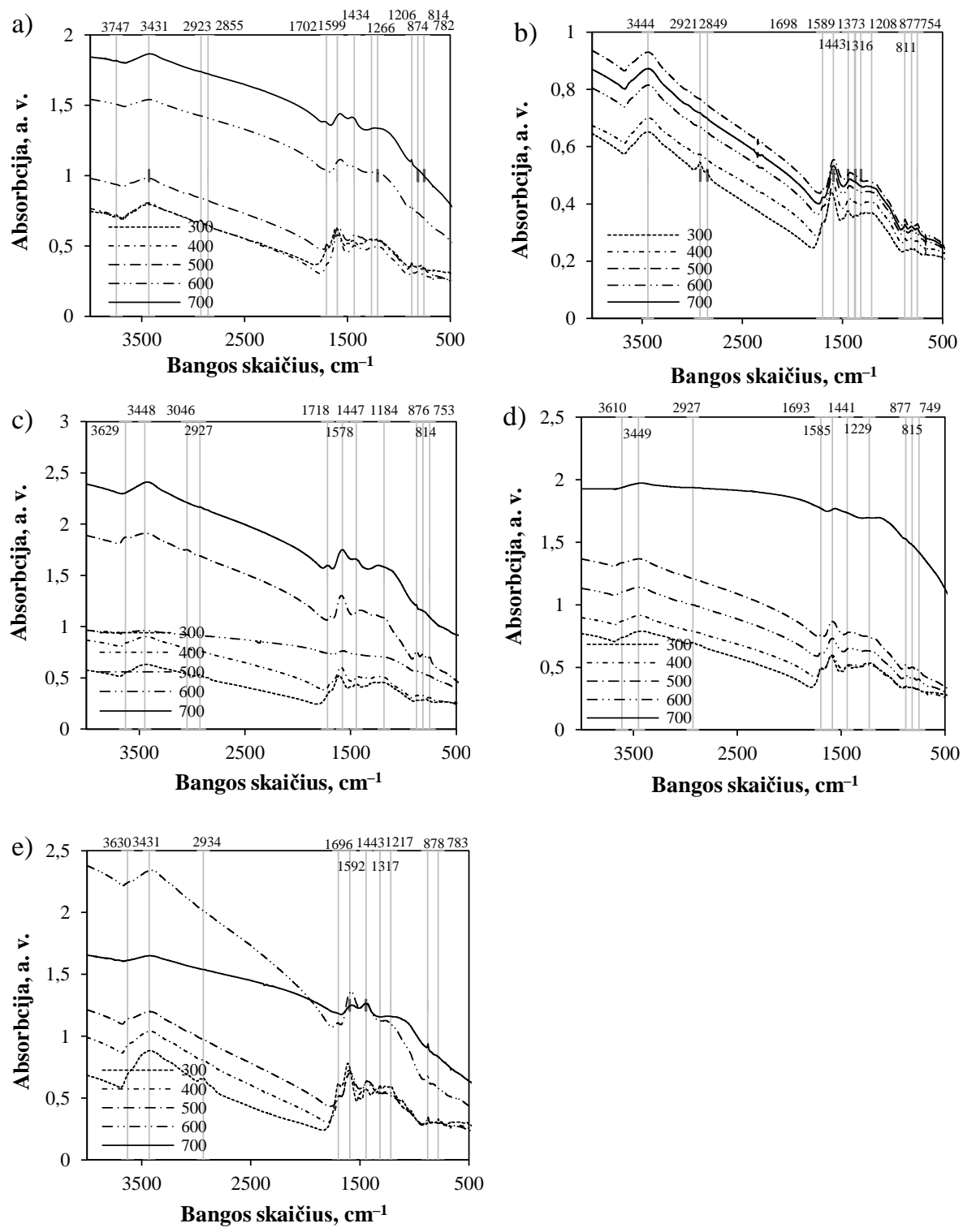

3.18 pav. Bioanglies Furjè transformacijos infraraudonųjų spindulių spektrai: a) pušies žievès; b) beržo žievès; c) pušies medienos; d) beržo medienos; e) kanapių, $n=2$

Fig. 3.18. Fourier-transform infrared spectra of biochar: a) pine bark; b) birch bark;

c) pine wood; d) birch wood; e) hemp, $n=2$ 
Visų bioanglies tipų vandens laikomoji geba (VSG) didejo augant temperatūrai: pušies žievès - nuo 1,1 iki 3,1 karto, beržo žievès - nuo 0,9 iki 2,1 karto, pušies medienos - nuo 1,5 iki 3,9 karto, beržo medienos - nuo 1,3 iki 2,2 karto ir kanapių - nuo 1,9 iki 9,1 karto (3.19 pav.). Lyginant medienos ir žievès bioanglies tipus, VSG buvo didesnè pušies medienos atveju nei žievès. VSG arba medžiagos geba sulaikyti vandeni priklauso nuo poringumo ir porų tarpusavio susijungimo. Dẻl to aukštatemperatūrè bioanglis gali sulaikyti daugiau vandens savo poringoje struktūroje. Žematemperatūriai bioanglies tipai gali būti mažiau prieinami vandeniui dèl mažesnio poringumo, porų tarpusavio susijungimo ir dervų, užkemšančių bioanglies poras (Weber, Quicker, 2018).

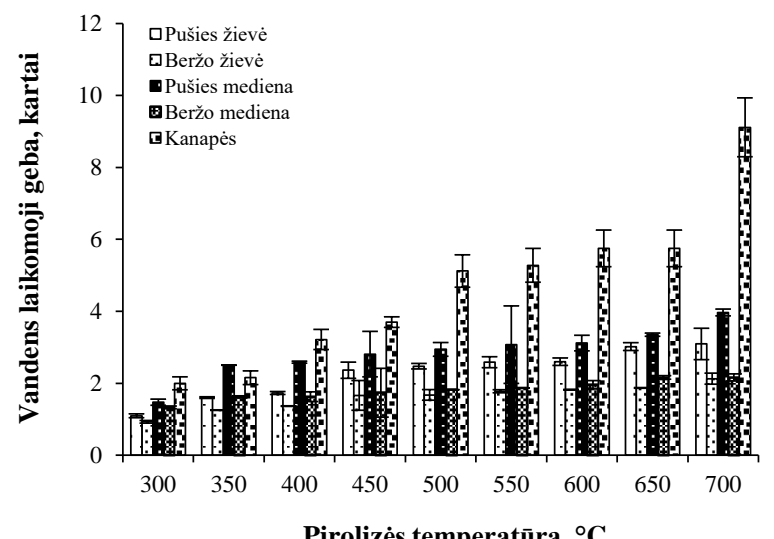

3.19 pav. Lignoceliuliozinès bioanglies $\left(300-700{ }^{\circ} \mathrm{C}\right)$ vandens laikomoji geba (kartai, lyginant prisotintos ir neprisotintos bioanglies svori), $n=3$

Fig. 3.19. Water holding capacity (by times, compared weight of saturated and unsaturated biochar) of lignocellulosic biochar $\left(300-700^{\circ} \mathrm{C}\right), n=3$

Bioanglies tipų drèkumas didejo kylant temperatūrai (3.20 pav.). Beržo ir pušies žievès bioanglies tipai buvo hidrofobiškiausi, nes jų hidrofobiškumas išsilaike iki $550^{\circ} \mathrm{C}$. Temperatūrai toliau kylant iki $700^{\circ} \mathrm{C}$, jų hidrofobiškumas visiškai išnyko. Tai būtų galima aiškinti didesniu žievès lignino kiekiu ir porų užsikimšimo dervomis efektu, nes alifatiniai junginiai, sudarantys dervas, garuoja tik aukštose temperatūrose. Beržo medienos bioanglis visose temperatūrose išlaikė nežymų hidrofobiškumą (VLSL $=2,47-2,33 \mathrm{~s}$ ). Panašiai dideliu drékumu pasižymejjo kanapių ir pušies medienos bioanglies tipai, kurie jau nuo $350{ }^{\circ} \mathrm{C}$ prarado savo pradinị hidrofobiškumą (VLSL - 8340-14,1 s kanapių atveju ir 2945-3,53 s - pušies medienos). Bioanglies savybių pokyčiai, ịtraukiant drèkumą, stipriai siejasi su biochemine žaliavos sudètimi. Remiantis Vigouroux 
(2001) tyrimu, mediena pasižymi šiomis komponentu koncentracijomis: celiuliozès turi 40-45\%, lignino 25-35\% minkštojoje medienoje ir 17-25\%kietojoje, $20 \%$ hemiceliuliozès - minkštojoje ir 15-35 \% - kietojoje. Žievejje šis komponentų išsidèstymas yra atvirkštinis: daugiausia randama lignino (43,8 \%), mažiau hemiceliuliozès $(29,8 \%)$ ir mažiausiai celiuliozės $(24,8 \%)$.

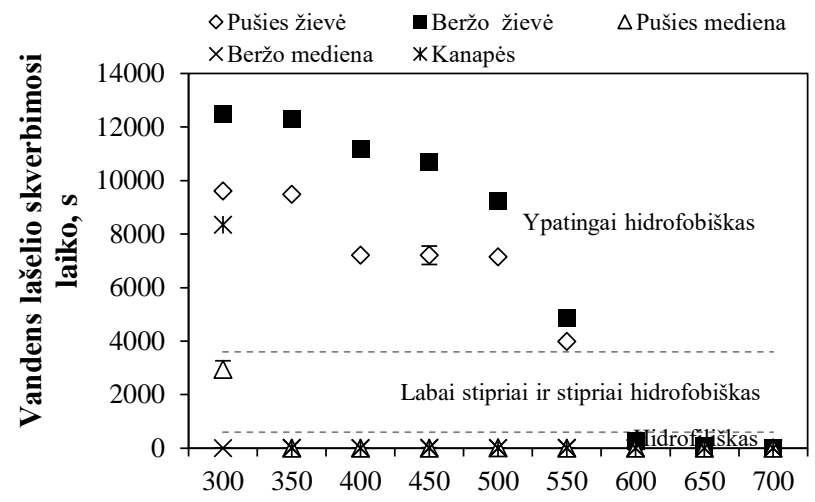

Pirolizès temperatūra, ${ }^{\circ} \mathrm{C}$

3.20 pav. Lignoceliuliozinès bioanglies $\left(300-700^{\circ} \mathrm{C}\right)$ drèkumas (s), $n=3$

Fig. 3.20. Wettability (s) of lignocellulosic biochar $\left(300-700^{\circ} \mathrm{C}\right), n=3$

Kinney et al. (2012) tyrime bioanglies tipai iš kukurūzų kotų, magnolijos lapų ir obelų medienos buvo hidrofobiški $\left(300-400^{\circ} \mathrm{C}\right)$, tačiau tapo hidrofiliški $500-$ $600{ }^{\circ} \mathrm{C}$ temperatūroje. Drèkumo pokyčių priklausomai nuo temperatūros intervalai nèra universalūs, nes Smetanova et al. (2013) nustaté, kad medienos ir žievès bioanglis $\left(500-600^{\circ} \mathrm{C}\right)$ išlaiko savo hidrofobiškumą. Panašiai šiame tyrime žievių bioanglies hidrofobiškumas buvo prarastas tik esant $600{ }^{\circ} \mathrm{C}$.

Bioanglies tipų paviršiaus ploto, porų tūrių (bendrasis ir mikroporų) bei porų dydžio rezultatai pateikti 3.3 lentelëje. Ryšys tarp žaliavų SPP ir temperatūros buvo teigiamas, kaip kad nustatè ir kiti autoriai (Pituello et al., 2014). Visų žaliavų atvejais nuo $500{ }^{\circ} \mathrm{C}$ pastebimas staigus paviršiaus ploto padidejimas, kuris buvo 191 kartą (pušies žievès), 38 kartus (pušies medienos), 1,1 karto (beržo medienos) ir 155 kartus (kanapių) didesnis, lyginant su $400^{\circ} \mathrm{C}$. Beveik visų žaliavų atvejais (išskyrus beržo medieną), didžiausias SPP pasiekiamas esant $700{ }^{\circ} \mathrm{C}$. Didžiausiu SPP pasižymejjo pušies žievès bioanglis $\left(700^{\circ} \mathrm{C} ; 421 \mathrm{~m}^{2} / \mathrm{g}\right)$. Bendrasis porų tūris didejjo beveik visų žaliavų atvejais (išskyrus beržo žievès) iki $600^{\circ} \mathrm{C}$. Matomas staigus 19 ir 2 kartų bendrojo porų tūrio padidejjimas nuo $500{ }^{\circ} \mathrm{C}$ iki $600{ }^{\circ} \mathrm{C}$ atitinkamai pušies žievès ir beržo žievès atvejais. Medienos ir kanapių atvejais bendrasis porų tūris didèja esant $400-500{ }^{\circ} \mathrm{C}$. 
3.3 lentelè. Lignoceliuliozinès bioanglies $\left(300-700^{\circ} \mathrm{C}\right)$ savitasis paviršiaus plotas, bendrasis ir mikroporų tūris ir porų dydis, ND - nèra duomenų

Table 3.3. Specific surface area, total and micropore volume, pore size of lignocellulosic biochar $\left(300-700^{\circ} \mathrm{C}\right), \mathrm{ND}$ - no data

\begin{tabular}{|c|c|c|c|c|c|}
\hline $\begin{array}{l}\text { Žaliavos } \\
\text { tipas }\end{array}$ & $\begin{array}{c}\text { Pirolizès } \\
\text { temperatūra, } \\
{ }^{\circ} \mathrm{C}\end{array}$ & $\begin{array}{c}\text { Savitasis } \\
\text { paviršiaus } \\
\text { plotas, } \mathrm{m}^{2} / \mathrm{g}\end{array}$ & $\begin{array}{l}\text { Bendrasis } \\
\text { tūris, } \mathrm{cm}^{3} / \mathrm{g}\end{array}$ & $\begin{array}{l}\text { Mikroporų } \\
\text { tūris, } \mathrm{cm}^{3} / \mathrm{g}\end{array}$ & $\begin{array}{l}\text { Vidutinis } \\
\text { porų } \\
\text { dydis, nm }\end{array}$ \\
\hline \multirow{5}{*}{$\begin{array}{l}\text { Pušies } \\
\text { žievė }\end{array}$} & 300 & ND & ND & ND & ND \\
\hline & 400 & 1,67 & 0,009 & 0,001 & 2,42 \\
\hline & 500 & 319 & 0,18 & 0,18 & 1,23 \\
\hline & 600 & 383 & 0,22 & 0,19 & 1,23 \\
\hline & 700 & 421 & 0,25 & 0,21 & 1,23 \\
\hline \multirow{4}{*}{$\begin{array}{l}\text { Beržo } \\
\text { žievè }\end{array}$} & 300 & 0,47 & 0,003 & $2,55 \cdot 10^{-8}$ & 3,17 \\
\hline & 500 & 111 & 0,09 & 0,06 & 1,93 \\
\hline & 600 & 329 & 0,19 & 0,18 & 1,18 \\
\hline & 700 & 381 & 0,22 & 0,19 & 1,18 \\
\hline \multirow{5}{*}{$\begin{array}{l}\text { Pušies } \\
\text { mediena }\end{array}$} & 300 & 4,81 & 0,003 & $4,03 \cdot 10^{-11}$ & 6,23 \\
\hline & 400 & 8,93 & 0,01 & 0,004 & 1,93 \\
\hline & 500 & 337 & 0,19 & 0,21 & 1,29 \\
\hline & 600 & 360 & 0,2 & 0,18 & 1,18 \\
\hline & 700 & 380,36 & 0,19 & 0,08 & ND \\
\hline \multirow{5}{*}{$\begin{array}{l}\text { Beržo } \\
\text { mediena }\end{array}$} & 300 & 2,43 & 0,003 & $4,03 \cdot 10^{-12}$ & 3,32 \\
\hline & 400 & 21,9 & 0,02 & 0,01 & 1,85 \\
\hline & 500 & 304 & 0,18 & 0,19 & 1,41 \\
\hline & 600 & 345 & 0,19 & 0,18 & 1,18 \\
\hline & 700 & 291 & 0,16 & 0,12 & ND \\
\hline \multirow[t]{5}{*}{ Kanapès } & 300 & 6,99 & 0,007 & $2,22 \cdot 10^{-12}$ & 4,54 \\
\hline & 400 & 2,15 & 0,03 & $6,07 \cdot 10^{-8}$ & 1,85 \\
\hline & 500 & 334 & 0,19 & 0,18 & 1,23 \\
\hline & 600 & 391 & 0,26 & 0,19 & 1,29 \\
\hline & 700 & 392 & 0,24 & 0,19 & 1,13 \\
\hline
\end{tabular}


Pituello et al. (2014) nustatè, kad porų tūriai taip pat didejo visų žaliavų atvejais priklausomai nuo temperatūros, kuris buvo ryškiausias fermentuotų ir vynuogiu atlieku bioanglies $\left(450-550^{\circ} \mathrm{C}\right)$ atveju ir didejo atitinkamai 4 ir 9 kartus. Zhao et al. (2017) nustatè, kad obelų medienos bioanglies $\left(500{ }^{\circ} \mathrm{C}\right)$ poringumas padidejjo dèl lignino suskaidymo bei greito $\mathrm{H}_{2}$ ir $\mathrm{CH}_{4}$ išlaisvinimo. Tai lèmé staigų paviršiaus ploto ir porų tūrio padidèjimą. Toliau iki $600{ }^{\circ} \mathrm{C}$ padidejjusi temperatūra lèmè dramatišką SPP ir bendrojo porų tūrio padidejjimą (atitinkamai nuo 37,2 iki $109 \mathrm{~m}^{2} / \mathrm{g}$ ir nuo $12,4 \mathrm{iki} 58,5 \mathrm{~cm}^{3} / \mathrm{g}$ ).

Tam, kad būtų galima atskleisti ryši tarp bioanglies VSG bei kitų jos fizikinių ir cheminių savybių $(\mathrm{C}, \mathrm{H}, \mathrm{O}$ kiekių, $\mathrm{pH}$, elektrinio laidžio, peleningumo, bendrojo porų tūrio, mikroporų tūrio ir porų dydžio) bei kitu atveju, jos drèkumo bei kitų fizikinių ir cheminių savybių $(\mathrm{C}, \mathrm{H}, \mathrm{O}$ kiekių, $\mathrm{pH}$, elektrinio laidžio, peleningumo, bendrojo porų tūrio, mikroporų tūrio, porų dydžio, $-\mathrm{OH}$ ir $\mathrm{C}-\mathrm{O}$ funkcinių grupių intensyvumo), buvo gautos vienanarès lygtys, naudojantis daugialype regresine analize. Gautos lygtys bioanglies vandens laikomosios gebos (3.1 lygtis) ir drèkumo (3.2 lygtis) prognozei:

$$
\begin{gathered}
Y=1,508+(0,27 \times P) \\
\log (Y)=0,796-(2,13 \times \log (V P D)),
\end{gathered}
$$

čia $P$ - bioanglies peleningumas, \%; VPD - bioanglies vidutinis porų dydis, nm.

3.4 lentelè. Daugialypès regresinès analizès rezultatai naudojant bioangli $(n=14)$

Table 3.4. Results of multiple regression analysis for biochar $(n=14)$

\begin{tabular}{|l|l|l|l|l|}
\hline \multicolumn{1}{|c|}{$\begin{array}{c}\text { Priklausomasis } \\
\text { kintamasis }\end{array}$} & $\begin{array}{c}\text { Nepriklausomasis } \\
\text { kintamasis }\end{array}$ & \multicolumn{1}{|c|}{$R^{2}$} & $F$ & $p$ \\
\hline $\begin{array}{l}\text { Vandens } \\
\text { laikomoji geba }\end{array}$ & Peleningumas & 0,77 & 22,9 & 0,001 \\
\hline Drékumas & Vidutinis poru dydis & 0,54 & 8,16 & 0,024 \\
\hline
\end{tabular}

Bioanglies VSG (k.) gali būti prognozuojama remiantis jos peleningumu. Buvo gautos panašios bioanglies tipu VSG vertès, apskaičiuotos realiomis, remiantis 3.1 lygtimi (3.21 pav.). Tiksliausiai buvo prognozuotos $\geq 500{ }^{\circ} \mathrm{C}$ bioanglies tipų VSG, kur skirtumas tarp realių ir apskaičiuotų verčių siekė, pavyzdžiui, 0,18 karto kanapių bioanglies $\left(600^{\circ} \mathrm{C}\right)$ atveju. Determinacijos koeficientas $R^{2}(0,77)$ ir mažesnè nei $0,05 p$ vertè $(0,001)$ reiškia, kad modelis yra tinkamas, nes jis paaiškina 77 \% priklausomojo kintamojo sklaidos apie jo vidurki (3.5 lentelè). Koreliacijos koeficientas šio modelio atveju siekè 0,87 (3.5 lentelè). Remiantis kitu tyrimu (Gondim et al., 2018), bioanglies VSG taip pat gali būti 
siejama su porų dydžiu. Mažesnis makroporų ir didesnis mikroporų kiekis gali būti siejamas su didesne medienos (caatinga) bioanglies VSG. Bioanglies VSG ryšį su peleningumu galima aiškinti tuo, bioanglis, pagaminta iš daugiau pelenų turinčių žaliavų (žievès), paprastai turi mažesnį SPP, nei gaminta iš mažiau pelenų turinčių žaliavų (medienos), nes pelenai blokuoja porų ertmes. Dẻl to medienos bioanglies tipai pasižymi didesne VSG, lyginant su žievès.

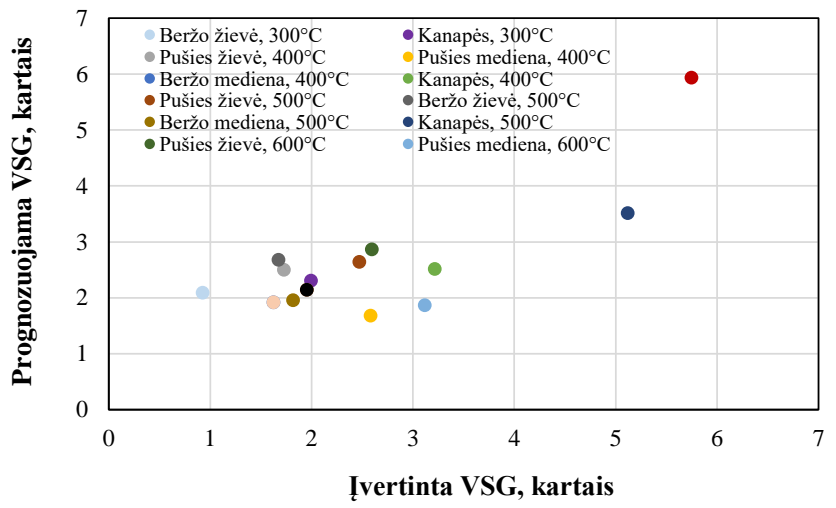

3.21 pav. Ryšys tarp eksperimentiniu būdu ịvertintų ir prognozuojamų bioanglies vandens laikomosios gebos verčiu (kartais), $n=14$

Fig. 3.21. Relationship between experimentally estimated and predicted values of the biochar water holding capacity (by times), $n=14$

3.5 lentelè. Regresinès analizès statistiniai parametrai $(n=14)$

Table 3.5. Statistical parameters of regression analysis $(n=14)$

\begin{tabular}{|l|l|l|l|}
\hline $\begin{array}{c}\text { Priklausomasis } \\
\text { kintamasis }\end{array}$ & \multicolumn{1}{|c|}{ Nepriklausomieji kintamieji } & $p$ verte & \multicolumn{1}{|c|}{$\begin{array}{c}\text { Koreliacijos } \\
\text { koeficientas } R\end{array}$} \\
\hline $\begin{array}{l}\text { Vandens } \\
\text { laikomoji geba }\end{array}$ & Peleningumas & 0,001 & 0,87 \\
\cline { 2 - 4 } & $\mathrm{C}$ & 0,28 & 0,33 \\
\cline { 2 - 4 } & $\mathrm{O}$ & 0,19 & $-0,39$ \\
\cline { 2 - 4 } & $\mathrm{H}$ & 0,69 & $-0,12$ \\
\cline { 2 - 4 } & $\mathrm{pH}$ & 0,35 & 0,28 \\
\cline { 2 - 4 } & Elektrinis laidis & 0,06 & 0,54 \\
\cline { 2 - 4 } & Bendrasis tūris & 0,27 & 0,33 \\
\cline { 2 - 4 } & Mikroporų tūris & 0,29 & 0,31 \\
\cline { 2 - 4 } & Porų dydis & 0,16 & $-0,41$ \\
\hline
\end{tabular}


Bioanglies drèkumas $s$ gali būti prognozuojamas remiantis jos vidutiniu porų dydžiu (VPD). Buvo gautos panašios logaritminio drėkumo vertės, apskaičiuotos realiomis, remiantis 2 lygtimi (3.22 pav.). Tiksliausiai buvo prognozuotas $\geq 500{ }^{\circ} \mathrm{C}$ bioanglies tipų drėkumas, kai skirtumas tarp realios ir apskaičiuotos verčiu siekè $0,01 \mathrm{~s}$ pušies žievès bioanglies $\left(500^{\circ} \mathrm{C}\right)$ atveju. Didesnis nei vidutinis determinacijos koeficientas $R^{2}(0,54)$ ir maža $p$ reikšmè $(0,024)$ reiškia, kad modelis yra tinkamas, nes jis paaiškina $54 \%$ priklausomojo kintamojo sklaidos apie jo vidurki (3.4 lentelè). Koreliacijos koeficientas šio modelio atveju sieké 0,73 (3.6 lentelè). Bioanglies drèkumas ir porų dydis siejasi tuo, kad mažèjantys porų dydžiai, didėjant temperatūrai, didina fizinę vandens adsorbciją. Kitu tyrimu (Zhang, You, 2013) įvertinta, kad bioanglies vandens absorbcijos greitis buvo veikiamas tiek bendrojo porų tūrio, tiek vidutinio porų skersmens.

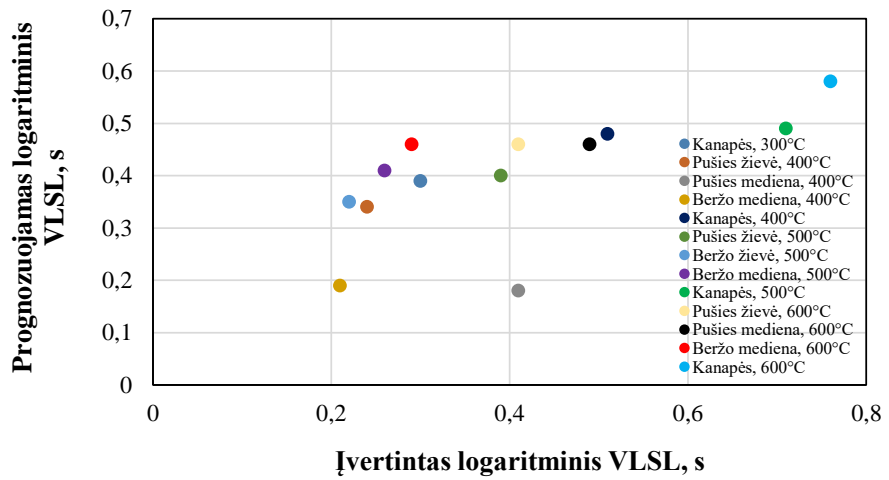

3.22 pav. Ryšys tarp eksperimentiniu būdu ịvertintų ir prognozuojamų bioanglies drẻkumo verčių $s, n=14$

Fig. 3.22. Relationship between experimentally estimated and predicted values of biochar wettability $s, n=14$

3.6 lentelè. Regresinès analizès statistiniai parametrai $(n=14)$

Table 3.6. Statistical parameters of regression analysis $(n=14)$

\begin{tabular}{|l|l|l|l|}
\hline $\begin{array}{c}\text { Priklausomasis } \\
\text { kintamasis }\end{array}$ & Nepriklausomieji kintamieji & $p$ verte & $\begin{array}{c}\text { Koreliacijos } \\
\text { koeficientas } R\end{array}$ \\
\hline $\begin{array}{l}\text { Bioanglies } \\
\text { drėkumas }\end{array}$ & Porų dydis & 0,02 & 0,73 \\
\cline { 2 - 4 } & $\mathrm{C}$ & 0,35 & $-0,42$ \\
\cline { 2 - 4 } & $\mathrm{O}$ & 0,18 & 0,52 \\
\cline { 2 - 4 } & $\mathrm{H}$ & 0,23 & 0,48 \\
\cline { 2 - 4 } & Peleningumas & 0,79 & $-0,11$ \\
\hline
\end{tabular}


3.6 lentelès pabaiga

\begin{tabular}{|l|l|l|l|}
\hline $\begin{array}{l}\text { Priklausomasis } \\
\text { kintamasis }\end{array}$ & Nepriklausomieji kintamieji & $p$ vertė & $\begin{array}{l}\text { Koreliacijos } \\
\text { koeficientas } R\end{array}$ \\
\hline \multirow{7}{*}{} & $\mathrm{pH}$ & 0,94 & 0,03 \\
\cline { 2 - 4 } & Elektrinis laidis & 0,44 & $-0,32$ \\
\cline { 2 - 4 } & Bendrasis porų tūris & 0,66 & $-0,19$ \\
\cline { 2 - 4 } & Mikroporų tūris & 0,62 & 0,21 \\
\cline { 2 - 4 } & -OH grupès intensyvumas & 0,46 & $-0,31$ \\
\cline { 2 - 4 } & C-O grupès intensyvumas & 0,51 & $-0,28$ \\
\hline
\end{tabular}

Bioanglies VSG ir drėkumo rezultatai buvo statistiškai validuoti. VSG atveju stipri koreliacija grindžiama keletu kitu testų: RMSE $(0,79)$, MAPE $(30,6 \%)$, MSE $(0,63)$ ir MAD $(0,64)(3.7$ lentelè). Bioanglies drèkumo atveju vidutiné koreliacija buvo grindžiama tais pačiais parametrais: $\operatorname{RMSE}(0,13)$, MAPE $(28,4 \%)$, MSE $(0,02)$ ir MAD $(0,1)$. Mažesnès visų parametrų vertès paprastai rodo geresnę duomenų atitiktị modeliui. Remiantis MAPE, abu modeliai gali būti laikomi kaip priimtini, nes jų vertès yra tarp 20 ir 50 (Saletnik et al., 2019). Kai RMSE verte yra mažesnè, tuomet modelis pasižymi geresne prognozavimo geba ir geresniu simuliaciniu atlikimu (Woschnagg, Cipan, 2004).

3.7 lentelè. Statistiniai parametrai, naudoti eksperimentinèms ir prognozuojamoms bioanglies vandens laikomosios gebos ir drėkumo vertems palyginti

Table 3.7. Statistical parameters used to compare experimental and predicted values of biochar water holding capacity and wettability

\begin{tabular}{|l|l|l|}
\hline \multicolumn{1}{|c|}{ Statistinis parametras } & $\begin{array}{c}\text { Bioanglies vandens } \\
\text { laikomoji geba, } \\
n=14\end{array}$ & \multicolumn{1}{|c|}{$\begin{array}{c}\text { Bioanglies } \\
\text { drékumas, } n=14\end{array}$} \\
\hline $\begin{array}{l}\text { Vidutinis absoliutusis nuokrypis } \\
\text { (MAD) }\end{array}$ & 0,64 & 0,1 \\
\hline Vidutinė kvadratinė paklaida (MSE) & 0,63 & 0,02 \\
\hline $\begin{array}{l}\text { Šaknis iš vidutinės kvadratinės } \\
\text { paklaidos (RMSE) }\end{array}$ & 0,79 & 0,13 \\
\hline $\begin{array}{l}\text { Vidutinė procentinè absoliučioji } \\
\text { paklaida (MAPE), \% }\end{array}$ & 30,6 & 28,4 \\
\hline
\end{tabular}

Remiantis RMSE kriterijumi, drèkumo modelis yra geresnis nei vandens laikomosios gebos. Remiantis analizių būdu ịvertintomis bioanglies savybėmis, buvo gauti du regresiniai modeliai. Lygtys buvo validuotos gautais duomenimis 
ir prognozuojamos hidrofizikinių savybių vertès buvo panašios lyginant su eksperimentiniais duomenimis, o tai rodo šių modelių universalumą bioanglies drëkumo ir VSG prognozei. Regresinių modelių vystymo tikslas - tiksliai prognozuoti skirtingų bioanglies tipų drékumą ir VSG, naudojantis analitiniais duomenimis, taip išsaugant kaštus ir laiką eksperimentams.

Taigi, nepriklausomai nuo temperatūros, pušies medienos bioanglies peleningumas $(0,58-3,99 \%)$ ir elektrinis laidis $\left(0,1-0,3 \mathrm{mS} / \mathrm{cm}, 400-700{ }^{\circ} \mathrm{C}\right) \mathrm{yra}$ mažiausias. Tarp visų žaliavų (išskyrus kanapes), pušies mediena pasižymėjo didesne VSG (1,48-3,97 kartai) ir yra viena iš dviejų žaliavų (kartu su beržo žievès), turinti didžiausią bendrą anglies kiekị (71,7-91,7 \%), dèl to gali išvystyti aromatingesnę ir poringesnę struktūrą, reikalingą mikroorganizmams. Matyti, kad pušies medienos bioanglis, nepriklausomai nuo temperatūros, pasižymėjo mažesniais $\mathrm{H} / \mathrm{C}$ atominiais santykiais $(0,06-2,21)$, kurie siejasi su didesniu jos aromatingumu ir kondensacijos laipsniu. Taip pat pušies medienos bioanglis beveik visame nagrinètame temperatūros intervale (išskyrus $300^{\circ} \mathrm{C}$ ), remiantis vandens lašelio skverbimosi laiko testu (VLSL), pasižymėjo hidrofiliškumu (VLSL $=1,6-12 \mathrm{~s}$ ), kuris yra svarbus lakiujų organinių junginių šalinimo efektyvumui biofiltracijoje. Vertinant visas žaliavas, pušies medienos bioanglis pasižymėjo savybėmis, palankiomis biofiltracijai, t. y. turejjo mažą pelenų kiekị ir elektrinị laidị, didesnị anglies kiekị, vandens laikomają gebą. Taip pat pušies medienos bioanglis nepriklausomai nuo temperatūros pasižymejjo absorbcijos pikais ties $3448 \mathrm{~cm}^{-1}, 1718 \mathrm{~cm}^{-1}, 1578 \mathrm{~cm}^{-1}, 1447 \mathrm{~cm}^{-1}$ bangos skaičiais, kurie rodo hidroksilinių, karboksilinių $\mathrm{C}=\mathrm{O}$ ir aromatinių $\mathrm{C}=\mathrm{C}$ funkcinių grupių buvimą jos struktūroje. Būtent hidroksilinès ir karboksilinès funkcinès grupès didina bioanglies hidrofiliškumą ir teršalų adsorbciją. Nustatyta, kad bioanglies VSG (77\% variacijos) gali būti prognozuojama remiantis jos peleningumu, o drékumas (54\% variacijos) - vidutiniu porų dydžiu. Daugiau pelenų turinčios žaliavos (žievès) bioanglies paviršiaus plotas yra paprastai mažesnis, lyginant su mažesnio peleningumo žaliavomis (mediena). Mažèjantys porų dydžiai, didejjant pirolizès temperatūrai, didina fizinę vandens adsorbciją.

\subsection{Bioanglies drèkumas, ivertintas vandens lašelio skverbimosi laiko testu, etanolio lašelio molingumo testu ir kontakto laipsnio analize}

Nežiūrintị tai, kad bioanglies drèkumas turi didelę reikšmę jos vandens laikomajai gebai bei pritaikymui aplinkosaugos technologijose, ši savybė vis dar nèra reguliariai tiriama. Tyrimo tikslas - įvertinti skirtingų pirolizès sąlygų ir žaliavos 
bioanglies drèkumą, remiantis prieinamais metodais, ir nustatyti tinkamiausią naudojant bioangli.

Beveik visų tirtų bioanglies tipų (išskyrus kanapes) drèkumas buvo didesnis (atitinkamai kontakto laipsnis mažèjo) esant aukštesnei temperatūrai $\left(700^{\circ} \mathrm{C}\right)$ ir ilgesniam (2 val.) kaitinimo laikui (3.23 pav.). Pilka punktyrinè linija žymi $90^{\circ}$ ribą, kuri skiria hidrofilišką $\left(<90^{\circ}\right)$ ir hidrofobišką $\left(>90^{\circ}\right)$ bioangli. Didžiausiu hidrofobiškumu pasižymejjo beržo žievès bioanglis (BŽ450-1;107), didžiausiu hidrofiliškumu - kanapių (K450-1; 65 $)$. Remiantis įvertintais kontakto laipsniais, visus pušies medienos ir kanapių bioanglies tipus galima vadinti hidrofiliškais $\left(<90^{\circ}\right) .450{ }^{\circ} \mathrm{C}$ pušies žievès (PŽ450-1; PŽ450-2), beržo žievès (BŽ450-1) ir beržo medienos (BM450-1) bioanglies tipai pagal nustatytus kontakto laipsnius (atitinkamai $101^{\circ}, 99^{\circ}, 107^{\circ}$ ir $102^{\circ}$ ) buvo hidrofobiniai.

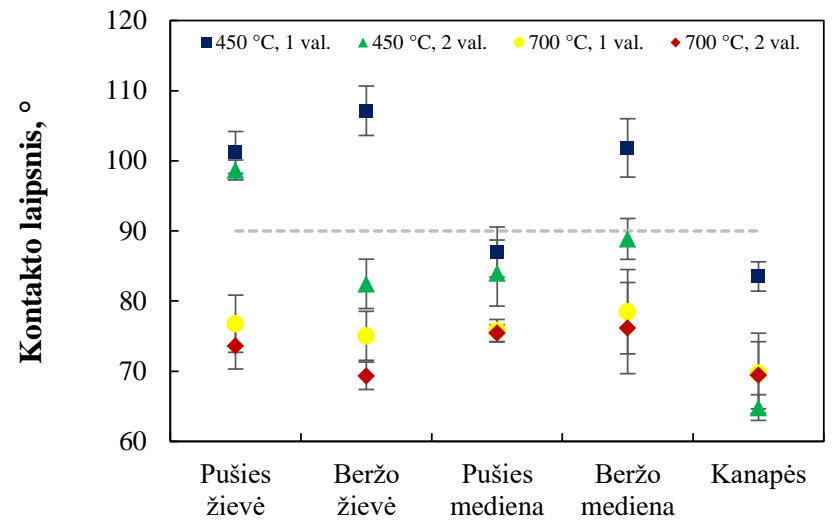

3.23 pav. Bioanglies tipų kontakto laipsniai tarp kietosios medžiagos paviršiaus ir vandens lašelio $(n=5)$

Fig. 3.23. Contact angles of biochar types between solid surface and water droplet $(n=5)$

Panašiai Dieguez-Alonso et al. (2018) nustate, kad medienos bioanglis pasižymejjo kontakto laipsniu, artimu $90^{\circ}$, o kukurūzų raugo bioanglis pasižymèjo šiek tiek mažesniais kontakto laipsniais. Nors teoriškai hidrofobiškumas laikomas tuomet, kai kontakto laipsnis yra $>90^{\circ}$, ịvertintos vertès, artimos $90^{\circ}$, šiame tyrime rodo didelị potencialų hidrofobiškumą. Kiti tyrèjai (Jeffery et al., 2015) taip pat nustate panašią bioanglies kontakto laipsnio mažèjimo tendenciją augant temperatūrai: $400{ }^{\circ} \mathrm{C}$ žolinès biomasès bioanglies kontakto laipsnis sieké $118^{\circ}$, o $600^{\circ} \mathrm{C}$ atveju $-101^{\circ}$. Kadangi kontakto laipsniai siekè daugiau nei $90^{\circ}$, abu bioanglies tipai buvo klasifikuojami kaip hidrofobiniai. 
Nustatant kontakto laipsnius, vandens lašelių formos ant bioanglies paviršiaus kito nuo elipsinès iki sferinès (atitinkamai BŽ700-1 ir PŽ450-1) (3.24 pav.). Pušies žievès kontakto laipsniai kito nuo $74^{\circ}$ iki $101^{\circ}$ (atitinkamai PŽ700-2 ir PŽ450-1), beržo žievès - nuo $69^{\circ}$ iki $107^{\circ}$ (atitinkamai BŽ700-2 ir BŽ450-1), pušies medienos - nuo $75^{\circ}$ iki $87^{\circ}$ (atitinkamai PM700-2 ir PM4501), beržo medienos - nuo $76^{\circ}$ iki $102^{\circ}$ (atitinkamai BM700-2 ir BM450-1) ir kanapiu - nuo $65^{\circ}$ iki $84^{\circ}$ (atitinkamai K450-2 ir K450-1).

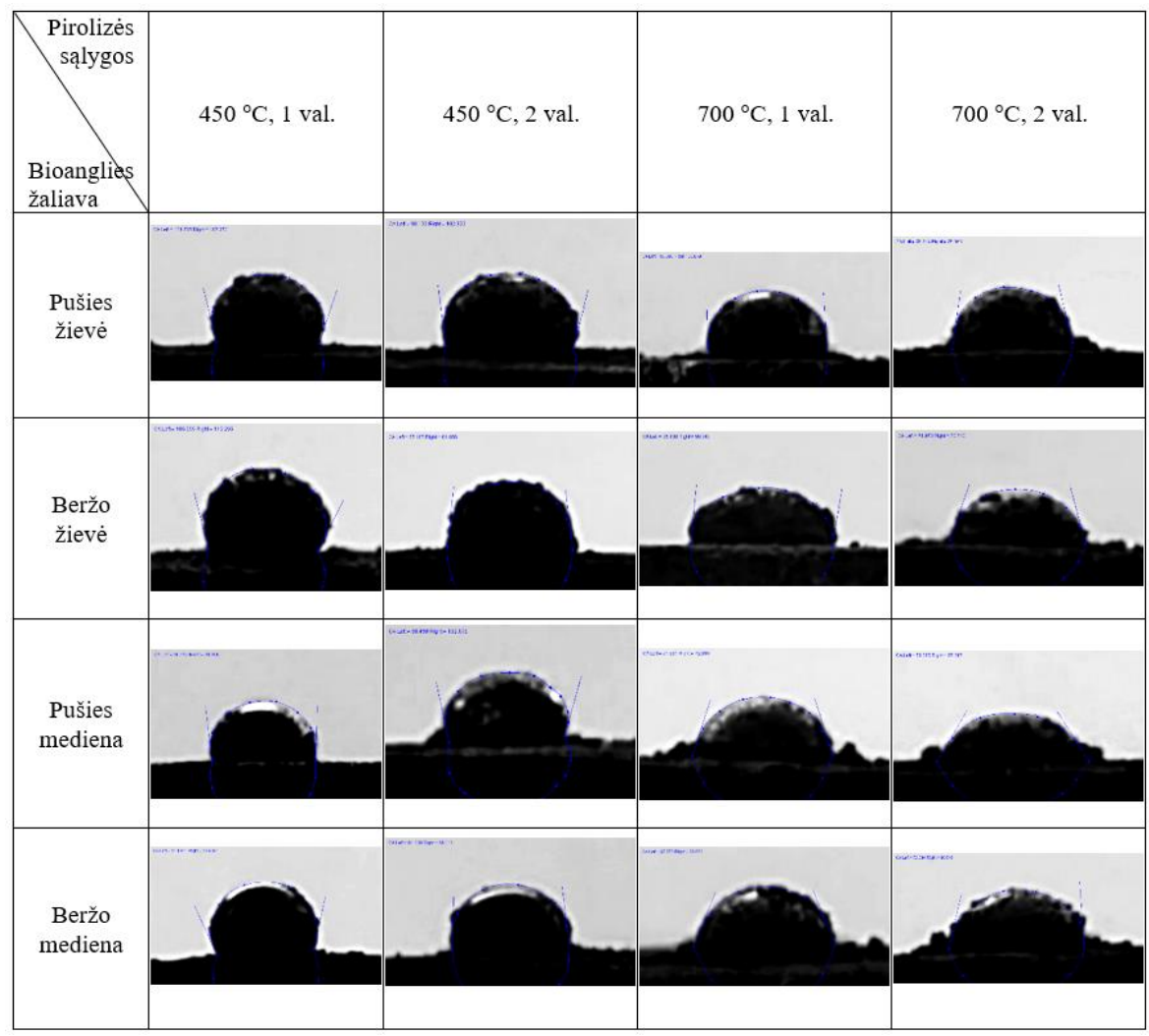

3.24 pav. Vandens lašeliai ant skirtingų bioanglies tipų paviršių (autorès paveikslas)

Fig. 3.24. Water droplets on the surfaces of different biochar types (author's figure)

Visų žaliavų $450{ }^{\circ} \mathrm{C}$ bioanglies tipai (išskyrus PM450-2 bei beržo medienos ir kanapių bioanglies tipus) pasižymėjo dideliu hidrofobiškumu (600-3600 s bioanglis labai hidrofobiška). Remiantis VLSL, hidrofobiškiausia buvo beržo žievès bioanglis (BŽ450-1) - jos VLSL siekè 1904 s. Visi kiti $450{ }^{\circ} \mathrm{C}$ bioanglies tipai pasižymèjo nežymiu hidrofobiškumu (VLSL nuo 1 iki $60 \mathrm{~s}$ ). Hidrofiliškumas būdingas keturiems $700{ }^{\circ} \mathrm{C}$ bioanglies tipams: beržo žievès 
(BŽ700-1, 1,33 s), pušies medienos (PM700-1, 1 s) ir kanapių (K700-1, K700-2, $1 \mathrm{~s}$ ). Visi kiti $700{ }^{\circ} \mathrm{C}$ bioanglies tipai buvo nežymiai hidrofobiški (VLSL nuo 1 iki 4 s) (3.25 pav.). Gauti VLSL testo rezultatai patvirtina mintį, kad didejant pirolizès temperatūrai bioanglies drèkumas didejja (Zornoza et al., 2016).

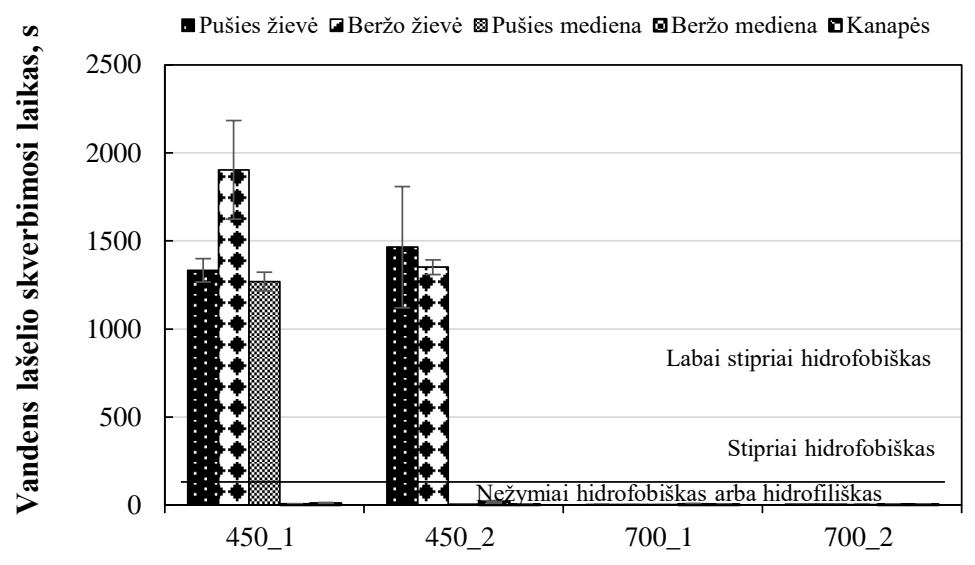

Pirolizès sąlygos, ${ }^{\circ} \mathrm{C} \_$val.

3.25 pav. Bioanglies tipų vandens lašelio skverbimosi laikas $(n=3)$

Fig. 3.25. Water droplet penetration time of biochar types $(n=3)$

Kaip ir kontakto laipsniu, taip ir VLSL testu buvo įvertinta, kad didejjant temperatūrai bioanglies drèkumas didèjo. Ši tendencija ypač matoma žievių bioanglies atvejais ir abiem kaitinimo laikams. Pušies žievès bioanglies, kaitinant 1 val., drèkumas kito nuo labai hidrofobiško (PŽ450-1, 1333 s) iki nežymiai hidrofobiško (PŽ700-1, 2,33 s). Ta pati drėkumo tendencija buvo ir esant 2 val. kaitinimo laikui (PŽ450-2, 1465 s; PŽ700- 2, 4 s). Beržo žievès bioanglies atveju drèkumas kito nuo labai hidrofobiško iki nežymiai hidrofobiško (BŽ450-1, $1904 \mathrm{~s}$ ir BŽ700-1, 1,33 s; BŽ450-2, $1351 \mathrm{~s}$ ir BŽ700-2, 4 s). Panašią drèkumo tendenciją priklausomai nuo temperatūros gavo ir Zornoza et al. (2016), kai $300{ }^{\circ} \mathrm{C}$ medvilnès atliekų bioanglis buvo suklasifikuota kaip labai hidrofobinè (>3600 s). Visų bioanglies tipų hidrofobiškumas visiškai išnyko perkopus $500{ }^{\circ} \mathrm{C}$ temperatūrą.

Remiantis ELM testo rezultatais, visų žaliavų bioanglies tipai pasižymėjo hidrofiliškumu (ELM indeksas lygus nuo 0 iki 2). Žievių bioanglies tipai (450-1 ir 450-2) pasižymėjo nežymiu hidrofiliškumu (ELM =2), o pušies medienos (PM450-1 ir PM450-2), beržo medienos (BM450-1 ir BM450-2) ir kanapių bioanglies tipai $(\mathrm{K} 450-1)$ buvo hidrofiliški $(\mathrm{ELM}=1)$. Visų žaliavų $700{ }^{\circ} \mathrm{C}$ 
temperatūroje bioanglies tipai pasižymèjo hidrofiliškumu $(\mathrm{ELM}=0)$ (3.8 lentelè).

3.8 lentelè. Bioanglies tipų drèkumo indeksas, įvertintas ELM testu

Table 3.8. Wettability index of biochar types as assessed by the MED test

\begin{tabular}{|l|l|l|l|l|l|}
\hline \multirow{2}{*}{$\begin{array}{c}\text { Pirolizès } \\
\text { sąlygos }\end{array}$} & \multicolumn{6}{|c|}{$\begin{array}{c}\text { Pušies } \\
\text { žievė }\end{array}$} & $\begin{array}{c}\text { Beržo } \\
\text { žievé }\end{array}$ & $\begin{array}{c}\text { Pušies } \\
\text { mediena }\end{array}$ & $\begin{array}{c}\text { Beržo } \\
\text { mediena }\end{array}$ & Kanapès \\
\hline $450^{\circ} \mathrm{C}, 1$ val. & 2 & 2 & 1 & 1 & 1 \\
\hline $450^{\circ} \mathrm{C}, 2$ val. & 2 & 2 & 1 & 1 & 0 \\
\hline $700^{\circ} \mathrm{C}, 1$ val. & 0 & 0 & 0 & 0 & 0 \\
\hline $700^{\circ} \mathrm{C}, 2$ val. & 0 & 0 & 0 & 0 & 0 \\
\hline
\end{tabular}

Kinney et al. (2012) ELM tyrimo rezultatais nustatyta, kad bioanglies hidrofobiškumas mažejo didejant temperatūrai, tačiau VLSL testu tokia tendencija nebuvo nustatyta. Bioanglies drèkumas varijavo nuo ypač hidrofobinio $(E L M=30$; PŽ350) iki hidrofilinio ( $E L M=0,1 ;$ PM600). Tarp visu žaliavų $350{ }^{\circ} \mathrm{C}$ pušies žievès ir tuopos medienos bioanglies tipai buvo ypač hidrofobiniai, lyginant su pušies medienos bioanglimi, o tai rodo su žaliava susijusius cheminius ir fizikinius skirtumus. Šiame tyrime taip pat gauta tendencija, kad žematemperatūre $\left(450{ }^{\circ} \mathrm{C}\right)$ pušies žievès bioanglis buvo mažiau drèki $(E L M=2)$ nei medienos bioanglis $(\mathrm{ELM}=1)$.

Pirsono koreliacija tarp bioanglies drèkumo, ivertinto skirtingais metodais, parode stipriai teigiamą linijinị ryšị tarp VLSL ir ELM bei tarp ELM ir kontakto laipsnio visų tirtų bioanglies tipų atvejais (3.9 lentelè). Juoda spalva žymi labai stiprų teigiamą arba neigiamą dviejų kintamujų ryši ( $r \geq 0,7$ arba $r \leq-0,7)$, tamsiai pilka spalva - stiprų teigiamą arba neigiamą ryši $(0,4 \leq r \geq 0,69$ arba $-0,4$ $\leq r \geq-0,69)$, o šviesiai pilka - kad nèra jokio ryšio tarp kintamujų $(r=0)$ (3.7 lentelè). Koreliacija tarp VLSL ir kontakto laipsnio buvo labai stipriai arba stipriai teigiama beveik visų bioanglies tipų atvejais (išskyrus beržo medienos, $r=0,09)$. Koreliacijos koeficientų rezultatai rodo, kad visi trys minèti drékumo ịvertinimo metodai yra tinkami bioanglies drèkumui įvertinti ir rodo panašią bioanglies drèkumo tendenciją. Kitu tyrimu (Suliman et al., 2017) nustatyta, kad bioanglies drèkumas didèjo augant temperatūrai ir šią tendenciją parodė ELM testas, bet ne VLSL.

Praktiniu požiūriu nors didžiausią drèkumo variaciją gali parodyti ELM testas, suteikdamas 8 skirtingas kategorijas priklausomai nuo drèkumo stiprio, šio tyrimo rezultatai to neparode, nes visi tipai igavo hidrofiliškumo arba nežymaus hidrofobiškumo kategoriją. 
3.9 lentelè. Pirsono koreliacijos koeficientai $r$ tarp skirtingų bioanglies drèkumo parametrų, nustatytų skirtingais metodais $(n=12)$

Table 3.9. Pearson correlation coefficients $(r)$ between different parameters of biochar wettability determined by different methods $(n=12)$

\begin{tabular}{|c|c|c|c|c|c|}
\hline \multirow{2}{*}{$\begin{array}{c}\text { Koreliuojami } \\
\text { parametrai }\end{array}$} & \multicolumn{5}{|c|}{ Žaliavos tipas } \\
\hline & $\begin{array}{c}\text { Pušies } \\
\text { žievė }\end{array}$ & $\begin{array}{l}\text { Beržo } \\
\text { žievè }\end{array}$ & $\begin{array}{l}\text { Pušies } \\
\text { mediena }\end{array}$ & $\begin{array}{l}\text { Beržo } \\
\text { mediena }\end{array}$ & Kanapès \\
\hline & 0,96 & 0,97 & 0,52 & 0,56 & 0,95 \\
\hline & 0,97 & 0,84 & 0,65 & 0,09 & 0,73 \\
\hline ELM & 0,99 & 0,72 & 0,94 & 0,81 & 0,87 \\
\hline
\end{tabular}

Kontakto laipsnis gali suteikti dvi kategorijas priklausomai nuo to, ar jis tarp medžiagos paviršiaus ir vandens lašelio viršija $90^{\circ}$, ar ne, todẻl šiuo atveju visi bioanglies tipai igavo dvi drékumo kategorijas - hidrofilišką arba hidrofobišką. Vertinant VLSL rezultatus, visi bioanglies tipai pasižymejjo didžiausia drèkumo ịvairove - nuo hidrofiliškos iki labai hidrofobiškos. Tai leidžia vertinti VLSL testą kaip tinkamiausią naudojant bioanglị. Kartu tai yra paprastas ir specialios įrangos nereikalaujantis testas. Vienintelis šio testo trūkumas - ilgai trunkantis procesas ir fizikinès reikšmès nebuvimas drèkumo teorijoje, lyginant su kontakto laipsniu, kuris gali būti naudojamas kietosios medžiagos energinei vertei apskaičiuoti.

VLSL atsakas ị kontakto laipsnio pokyčius $64,8-102^{\circ}$ intervale buvo labai nežymus tarp visų kanapių ir beržo medienos bioanglies tipų ir pušies medienos bioanglies (išskyrus PM450-1) (3.26 pav.). Aukštatemperatūrių kanapių ir pušies medienos bioanglies tipų hidrofiliškumas siejamas su mažesniu kontakto laipsniu (PM700-1; 75,8 ${ }^{\circ}$, o didelis hidrofobiškumas $(600 \mathrm{~s}<\mathrm{VLSL}<3600 \mathrm{~s})$ rodo $82,5^{\circ}$ ar didesni $107^{\circ}$ kontakto laipsnị (atitinkamai BŽ450-2 ir BŽ450-1). Kontakto laipsnių intervale $64,8-102^{\circ}$ visi beržo medienos bioanglies tipai pasižymėjo nežymiu hidrofobiškumu (1 s < VLSL < 60 s). Pušies žievès atveju VLSL buvo jautriausias kontakto laipsniams $77-99^{\circ}$ intervale, beržo žievès bioanglies atveju $-75-82^{\circ}$, pušies medienos atveju $-83-86^{\circ}$, nes nežymus kontakto laipsnio padidèjimas pakeitė VLSL kategoriją nuo hidrofiliškos iki labai hidrofobiškos. Ryšys tarp kontakto laipsnio ir VLSL yra naudingas gilinant žinias apie hidrofobišką bioanglị, nes VLSL galètų padèti suprasti apie tam tikros bioanglies kontak to laipsnius. Panašiai Leelamanie et al. (2008) nustatè, kad hidrofobinis stearino rūgštimi 
paveikto dirvožemio VLSL siekè $<1 \mathrm{~s}$ kontakto laipsniams esant nuo $11^{\circ}$ iki $69^{\circ}$ ir laipsniškai didejo jiems kylant nuo $69^{\circ}$ iki $88^{\circ}$.

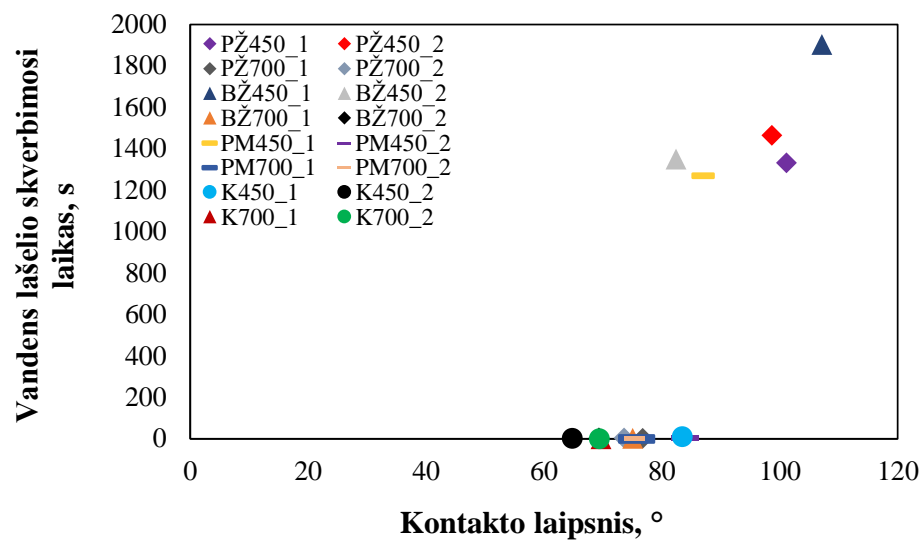

3.26 pav. Priklausomybė tarp lignoceliuliozinès bioanglies kontakto laipsnių $\left(^{\circ}\right)$ ir vandens lašelio skverbimosi laiko (s), $n=3$

Fig. 3.26. Dependence of the contact angles $\left(^{\circ}\right)$ of lignocellulosic biochar and water droplet penetration time (s), $n=3$

Praktiniu požiūriu, nors didžiausią drèkumo variaciją gali parodyti ELM testas, suteikdamas aštuonias kategorijas, šio tyrimo rezultatai to neparodè, nes visi bioanglies tipai igavo hidrofiliškumo arba nežymaus hidrofiliškumo kategoriją. Kontakto laipsnio analizès atveju visi bioanglies tipai igavo dvi drèkumo kategorijas - hidrofilišką arba hidrofobišką. Vertinant VLSL rezultatus, visi bioanglies tipai iggavo didžiausią drėkumo ịvairovę (nuo hidrofiliškos iki labai hidrofobiškos.

Taigi, remiantis skirtingo testo drèkumo ịvertinimais, VLSL testas yra tinkamiausias naudojant bioangli, nes gauti rezultatai parodè didžiausią bioanglies drėkumo variaciją priklausomai nuo žaliavos ir pirolizès sąlygų, lyginant su ELM testu bei kontakto laipsnio analize. Bioanglies drèkumas varijavo nuo hidrofiliško iki stipriai hidrofobiško. Hidrofiliškumas siejamas su mažesniais kontakto laipsniais (PM700-1; 76º, o hidrofobiškumas - su didesniais (BŽ450-1; 107º). Nors bioanglies drékumą yra lengviau įvertinti naudojantis VLSL testu ar EML testu, tačiau jie turi mažai mokslinès vertès. Fizikinių procesų tarp bioanglies ir vandens lašelio ištyrimo, kaip kad kietosios medžiagos kritinei paviršiaus ittempčiai, naudinga atlikti kontakto laipsnio analizę. 


\subsection{Bioanglies, modifikuotos fizikiniais ir cheminiais metodais, savybès}

Dèl bioanglies struktūrinių (paviršiaus ploto, mikroporingumo), cheminių (polinių funkcinių grupių) ir drèkumo savybių didinimo po pirolizès reikia taikyti bioanglies modifikacijos būdus. Bioanglies modifikacijai dažnai naudojami agresyvūs agentai, kaip kad rūgštys, šarmai ar druskos, kurie gali suardyti bioanglies struktūrą, yra brangūs ir aplinkai nepalankūs. Tyrimo tikslas - taikant gamtos procesais pagrịstus ir nebrangius būdus, modifikuoti bioanglị ir koreguoti jos savybes siekiant didinti hidrofiliškumą.

Didejant ramnolipidinio tirpalo koncentracijai (nuo 5 iki $40 \mathrm{mg} / \mathrm{l}$ ) tirpalų rūgštingumas didèjo nuo 6,41 iki 5,83 (3.10 lentelè). Lietaus vandens rūgštingumas buvo didesnis $(\mathrm{pH}=4,83)$ nei didžiausios koncentracijos ramnolipidinis tirpalas. Labai stipriu rūgštingumu pasižymejjo azoto rūgšties tirpalai, kurių pH mažèjo nuo 0,53 iki 0,43 didejjant tirpalo koncentracijai nuo $20 \%$ iki $65 \%$. Vertinant tirpalų elektrinio laidžio pokyčius priklausomai nuo tirpalu koncentracijos matyti, kad ramnolipidinio tirpalo atveju elektrinis laidis mažèjo nuo 7,47 iki $4,17 \mu \mathrm{S} / \mathrm{cm}$ didejjant jo koncentracijai atitinkamai nuo 5 iki $40 \mathrm{mg} / \mathrm{l}$. Naudojant azoto rūgšties tirpalą matyti priešinga tendencija: didèjant jo koncentracijai nuo 20 iki $65 \%$, elektrinis laidis atitinkamai didejo nuo 551 iki $634 \mu \mathrm{S} / \mathrm{cm}$.

3.10 lentelè. Tirpalų cheminès savybès, $n=3, \pm$ standartinis nuokrypis

Table 3.10. Chemical properties of the solutions, $n=3$, \pm standard deviation

\begin{tabular}{|l|l|l|}
\hline \multicolumn{1}{|c|}{ Tirpalas } & \multicolumn{1}{c|}{$\mathrm{pH}$} & \multicolumn{1}{c|}{$\begin{array}{c}\text { Elektrinis laidis, } \\
\mu \mathrm{S} / \mathrm{cm}\end{array}$} \\
\hline Dejonizuotas vanduo & $6,86 \pm 0,12$ & $15,1 \pm 0,2$ \\
\hline Lietaus vanduo & $4,83 \pm 0,1$ & $38,2 \pm 0,2$ \\
\hline Ramnolipidinis tirpalas (5 mg/l) & $6,41 \pm 0,07$ & $7,47 \pm 0,25$ \\
\hline Ramnolipidinis tirpalas (20 mg/l) & $5,92 \pm 0,05$ & $5,07 \pm 0,06$ \\
\hline $\mathrm{Ramnolipidinis} \mathrm{tirpalas} \mathrm{(40} \mathrm{mg/l)}$ & $5,83 \pm 0,03$ & $4,17 \pm 0,21$ \\
\hline $\mathrm{HNO}_{3}(20 \%)$ tirpalas & $0,53 \pm 0,01$ & $551 \pm 2,08$ \\
\hline $\mathrm{HNO}_{3}(40 \%)$ tirpalas & $0,47 \pm 0,03$ & $586 \pm 5,57$ \\
\hline $\mathrm{HNO}_{3}(65 \%)$ tirpalas & $0,42 \pm 0,02$ & $634 \pm 5,29$ \\
\hline
\end{tabular}


Remiantis beržo žievès bioanglies skirtingos frakcijos drèkumo rezultatais, matyti, kad mažèjant jos frakcijai drèkumas didèjo dèl trumpesnio VLSL (3.11 lentelè). Smulkiausia frakcija $(<300 \mu \mathrm{m})$ pasižymėjo nedideliu hidrofobiškumu ( $>1 \mathrm{~s})$, o vidutinė $(300-900 \mu \mathrm{m})$ ir stambi frakcija $(900 \mu \mathrm{m}-$ $1,6 \mathrm{~mm}$ ) buvo ypač hidrofobiška (atitinkamai $6120 \mathrm{~s}$ ir $18540 \mathrm{~s}$ ). Mažejant frakcijai nuo stambios iki vidutinès, bioanglies drèkumas didejo 3,03 karto.

3.11 lentelè. Beržo žievès bioanglies $\left(450^{\circ} \mathrm{C}, 2\right.$ val.) drèkumo priklausomybè nuo frakcijos, $n=3$

Table 3.11. Dependence of birch bark biochar $\left(450^{\circ} \mathrm{C}, 2 \mathrm{~h}\right)$ wettability on fraction, $n=3$

\begin{tabular}{|l|l|}
\hline \multicolumn{1}{|c|}{ Frakcijos dydis } & \multicolumn{1}{c|}{ Drèkumas, $\mathrm{s}$} \\
\hline$<300 \mu \mathrm{m}$ & $2,67 \pm 0,58$ \\
\hline $300-900 \mu \mathrm{m}$ & $6120 \pm 5$ \\
\hline $900 \mu \mathrm{m}-1,6 \mathrm{~mm}$ & $18541 \pm 3,21$ \\
\hline
\end{tabular}

Bioanglies frakcijos įtaka jos drèkumui nebuvo plačiai tyrinèta, tačiau daugiau tyrimų buvo atlikta bioanglies frakcijos poveikio dirvožemio VSG nustatyti. Liao and Thomas (2019) nustatè, kad bioanglies mažesnès dalelès parodè didesnę VSG nei didesnès. Tai galèjo lemti keli mechanizmai. Pirma, mažesnès dalelès gali lengvai užpildyti tuštumas tarp didesnių bioanglies dalelių bei tarp dirvožemio dalelių, taip mechaniškai užkemšant dirvožemio poras. Tai padidina vandens tekejjimo vingiuotumą ir mažina dirvožemio hidraulinį laidumą. Antra, mažesnių dalelių dydžių bioanglis turi daugiau suardytų vidinių makroporų, kurios didina sulaikomo vandens kiekị.

Bioanglies modifikacija ramnolipidinio tirpalo garais turèjo didesnị poveikị jos hidrofiliškumo didinimui nei dejonizuoto vandens (3.27 pav.). Dejonizuoto vandens garai buvo mažiausiai efektyvūs didinant bioanglies hidrofiliškumą, nes bioanglies drèkumas padidejjo tik 1,2 ir 1,7 k. (atitinkamai didèjant kaitinimo laikui nuo 1 iki 3 val.), lyginant su nemodifikuota bioanglimi. Didžiausios ramnolipidinio tirpalo koncentracijos $(40 \mathrm{mg} / \mathrm{l})$ garai buvo daugiau nei tris kartus efektyvesni, nes bioanglies drèkumas po modifikacijos padidejo 3,6 ir 3,9 k. (atitinkamai po 1 iki 3 val.). Vis dèlto modifikacija azoto rūgšties tirpalu (20 \%) buvo efektyvesnè bioanglies drèkumo didinimui, lyginant kitais modifikacijos būdais, nes drèkumas buvo 4,8 k. didesnis, lyginant su nemodifikuota bioanglimi, o tai yra $1,9 \mathrm{k}$. efektyviau nei poveikis $40 \mathrm{mg} / \mathrm{l}$ ramnolipidinio tirpalo garais. Tai galima aiškinti tuo, kad bioanglies poveikis rūgštimi didina deguonies turinčių funkcinių grupių skaičių ant jos paviršiaus (Wolak et al., 2017). Efektyviausiai bioanglies drékumą didino lietaus vandens garai (3 val.), kai jis padidejo $12 \mathrm{k}$., lyginant su nemodifikuota bioanglimi. Tokị rezultatą galèjo lemti lietaus vandens 
anijoninės bei katijoninès aktyvios paviršiaus medžiagos. Po modifikacijos visi bioanglies tipai išlaikè didelị pradinį hidrofobiškumą.

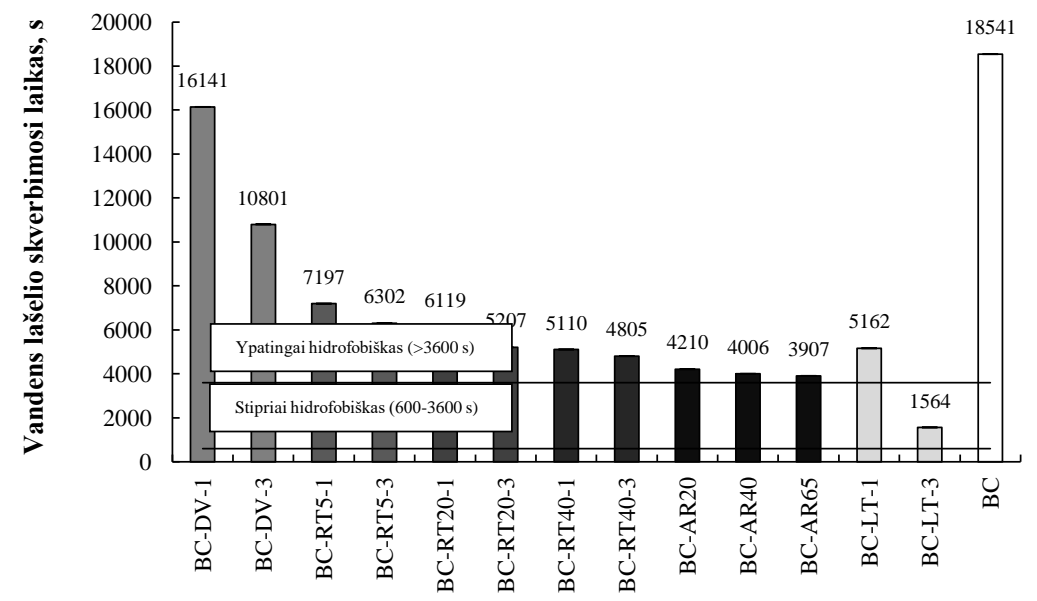

3.27 pav. Beržo žievès bioanglies drèkumo (s) priklausomybẻ nuo modifikacijos būdo: BC - nemodifikuota bioanglis; BC-DV-1 - modifikuota 1 val. dejonizuoto vandens garais; BC-DV-3 - modifikuota 3 val. dejonizuoto vandens garais; BC-RT40-1 modifikuota 1 val. ramnolipidinio tirpalo $(40 \mathrm{mg} / \mathrm{l})$ garais; BC-RT40-3 - modifikuota

3 val. ramnolipidinio tirpalo ( $40 \mathrm{mg} / \mathrm{l})$ garais; BC-RT20-1 - modifikuota 1 val. ramnolipidinio tirpalo $(20 \mathrm{mg} / \mathrm{l})$ garais; BC-RT20-3 - modifikuota 3 val. ramnolipidinio tirpalo (20 mg/l) garais; BC-RT5-1 - modifikuota 1 val. ramnolipidinio tirpalo (5 mg/l) garais; BC-RT5-3 - modifikuota 3 val. ramnolipidinio tirpalo $(5 \mathrm{mg} / \mathrm{l})$ garais; BCAR20 - modifikuota $20 \%$ azoto rūgšties tirpalu; BC-AR40 - modifikuota $40 \%$ azoto rūgšties tirpalu; BC-AR65 - modifikuota $65 \%$ azoto rūgšties tirpalu; BC-LT-1 modifikuota lietaus vandens garais 1 val.; BC-LT-3 - modifikuota lietaus vandens garais 1 val., $n=3, \pm$ standartinis nuokrypis

Fig. 3.27. Dependence of birch bark biochar wettability (s) on the modification technique: BC - unmodified biochar; BC-DV-1 - modified for $1 \mathrm{~h}$ with steam of deionized water; BC-DV-3 - modified for $3 \mathrm{~h}$ with steam of deionized water; BC-RT401 - modified $1 \mathrm{~h}$ with steam of rhamnolipid solution (40 mg/l); BC-RT40-3 - modified $3 \mathrm{~h}$ with steam of rhamnolipid solution $(40 \mathrm{mg} / \mathrm{l})$; BC-RT20-1 - modified for $1 \mathrm{~h}$ with steam of rhamnolipid solution (20 mg/l); BC-RT20-3 - modified for $3 \mathrm{~h}$ with steam of rhamnolipid solution $(20 \mathrm{mg} / \mathrm{l})$; BC-RT5-1 - modified for $1 \mathrm{~h}$ with steam of rhamnolipid solution (5 mg/l); BC-RT5-3 - modified for $3 \mathrm{~h}$ with steam of rhamnolipid solution (5 mg/l); BC-AR20 - modified with nitric acid (20\%); BC-AR40 - modified with nitric acid (40\%); BC-AR65 - modified with nitric acid (65\%); BC-LT-1 - modified for $1 \mathrm{~h}$ with steam of rainwater; BC-LT-3 - modified for $3 \mathrm{~h}$ with steam of rainwater, $n=3, \pm$ standard deviation 
Ankstesniais tyrimais tirta, kaip skirtingi bioanglies poveikio būdai veikia bioanglies paviršiaus fizikines ir chemines savybes. Kadangi bioanglies drèkumas daugiausia priklauso nuo jos paviršiaus ploto, poringumo, rūgštinių funkcinių grupių ir iš dalies nuo dujų, sulaikytų oru pripildytose porose, bioanglies aktyvacija garais gali būti puikus būdas didinti jos hidrofiliškumą. Tai dažnas bioanglies modifikacijos būdas, naudojamas bioanglies struktūriniam poringumui, paviršiaus plotui didinti ir nevisiško degimo likučiams pašalinti (Sizmur et al., 2017).

Kadangi žinoma, kad deguonies turinčios funkcinės grupès (hidroksilinès, karboksilinès ir karbonilinès) siejasi su bioanglies hidrofiliškumu, šiuo tyrimu buvo siekiama ịvertinti, ar jos susidaro beržo žievès bioanglyje po jos poveikio tirpalų garais ir azoto rūgštimi. Modifikuotos bioanglies FTIR spektrai pavaizduoti 3.28 paveiksle. Rezultatai parodè, kad paveiktos tirpalų garais bioanglies struktūroje atsirado $-\mathrm{OH}$ funkcinè grupé (pikai ties $3433 \mathrm{~cm}^{-1}$ ir $3421 \mathrm{~cm}^{-1}$ ) (3.30a pav.). Didžiausią ịtaką hidroksilinių funkcinių grupių sukūrimui ant bioanglies paviršiaus turèjo jos poveikis lietaus vandens garais (1 val.) dèl $-\mathrm{OH}$ piko didžiausio absorbcijos intensyvumo. Tai rodo, kad bioanglis, paveikta lietaus vandens garais, pasižymèjo geresniu drèkumu lyginant su dejonizuotu vandeniu. Didžiausias skirtumas tarp FTIR spektrų matyti tarp pikų absorbcijos verčių. Kuo didesnè šviesos absorbcijos vertė, tuo didesnè yra adsorbcija bei potencialiai didesnis konkrečios funkcinès grupès kiekis. Didesni adsorbcijos pikai ties $1697 \mathrm{~cm}^{-1}, 1592 \mathrm{~cm}^{-1}, 1435 \mathrm{~cm}^{-1}, 1250 \mathrm{~cm}^{-1}, 877 \mathrm{~cm}^{-1}$, $819 \mathrm{~cm}^{-1}$ ir $756 \mathrm{~cm}^{-1}$ bangos skaičiais rodo didesni $\mathrm{C}=\mathrm{O}, \mathrm{C}=\mathrm{C}, \mathrm{C}-\mathrm{O}$ ir $\mathrm{C}-\mathrm{H}$ funkcinių grupių skaičių paveikus po poveikio, lyginant su nemodifikuota bioanglimi. Nežymus pikas ties $1697 \mathrm{~cm}^{-1}$ bangos skaičiumi rodo $\mathrm{C}=\mathrm{O}$ jungties vibracijas, kurios žymi ketonų, kuinonų, karboksilinių ir aromatinių komponentų formavimąsi (Liu et al., 2018).

Lyginant rhamnolipidinių tirpalų garais modifikuotos bioanglies FTIR spektrus, matyti, kad modifikuotos bioanglies visų funkcinių grupių adsorbcijos intensyvumai buvo didesni ir tai rodo, kad modifikacija rhamnolipidinio tirpalo garais sukūrè daugiau deguonies turinčių funkcinių grupių, kurios yra svarbios adsorbcijai (3.28b pav.). Didesni adsorbcijos pikai ties $3421 \mathrm{~cm}^{-1}, 1599 \mathrm{~cm}^{-1}$, $1431 \mathrm{~cm}^{-1}, 1270 \mathrm{~cm}^{-1}, 876 \mathrm{~cm}^{-1}, 818 \mathrm{~cm}^{-1}$ ir $758 \mathrm{~cm}^{-1}$ rodo $-\mathrm{OH}, \mathrm{C}=\mathrm{O}, \mathrm{C}=\mathrm{C}, \mathrm{C}-\mathrm{O}$ ir $\mathrm{C}-\mathrm{H}$ funkcinių grupių kiekio padidejjimą po modifikacijos rhamnolipidinio tirpalo garais lyginant su nemodifikuota bioanglimi. Modifikacija $20 \mathrm{mg} / \mathrm{l}$ rhamnolipidiniu tirpalu (1 val.) turejjo geriausią poveikị funkcinių grupių sukūrimui ant bioanglies paviršiaus dèl didžiausių atskirų funkcinių grupių adsorbcijos intensyvumų.

Po bioanglies modifikacijos skirtingų koncentracijų azoto rūgšties tirpalais nustatyti trys stipriausi pikai: ties $3411 \mathrm{~cm}^{-1}, 1606 \mathrm{~cm}^{-1}$ ir $1385 \mathrm{~cm}^{-1}$ (3.28c pav.). Pikas ties $3411 \mathrm{~cm}^{-1}$ siejasi su hidroksilinėmis $-\mathrm{OH}$ funkcinèmis grupèmis, pikas 
ties $1606 \mathrm{~cm}^{-1}$ - su $\mathrm{C}=\mathrm{O}, \mathrm{C}=\mathrm{C}$ ir $\mathrm{C}=\mathrm{N}$ funkcinemis grupèmis bei pikas ties $1385 \mathrm{~cm}^{-1}$ - su $\mathrm{N}=\mathrm{O}$ vibracijomis. Panašiai Tan et al. (2017) nustatè, kad pikas ties $1410 \mathrm{~cm}^{-1}$ atsiranda dèl laktoninès struktūros, kuri atsiranda po poveikio rūgštimi. Padidèjęs deguonies turinčių funkcinių grupių kiekis ant bioanglies po jos modifikacijos azoto rūgšties tirpalais gali paaiškinti jos geresnę adsorbcinę gebą vandeniui. Lyginant skirtingų koncentracijų poveiki paviršiaus funkcinių grupių sukūrimui, $40 \%$ azoto rūgšties tirpalas turèjo didžiausią poveikį dèl didžiausių adsorbcijos intensyvumų lyginant su kitų koncentracijų tirpalais.
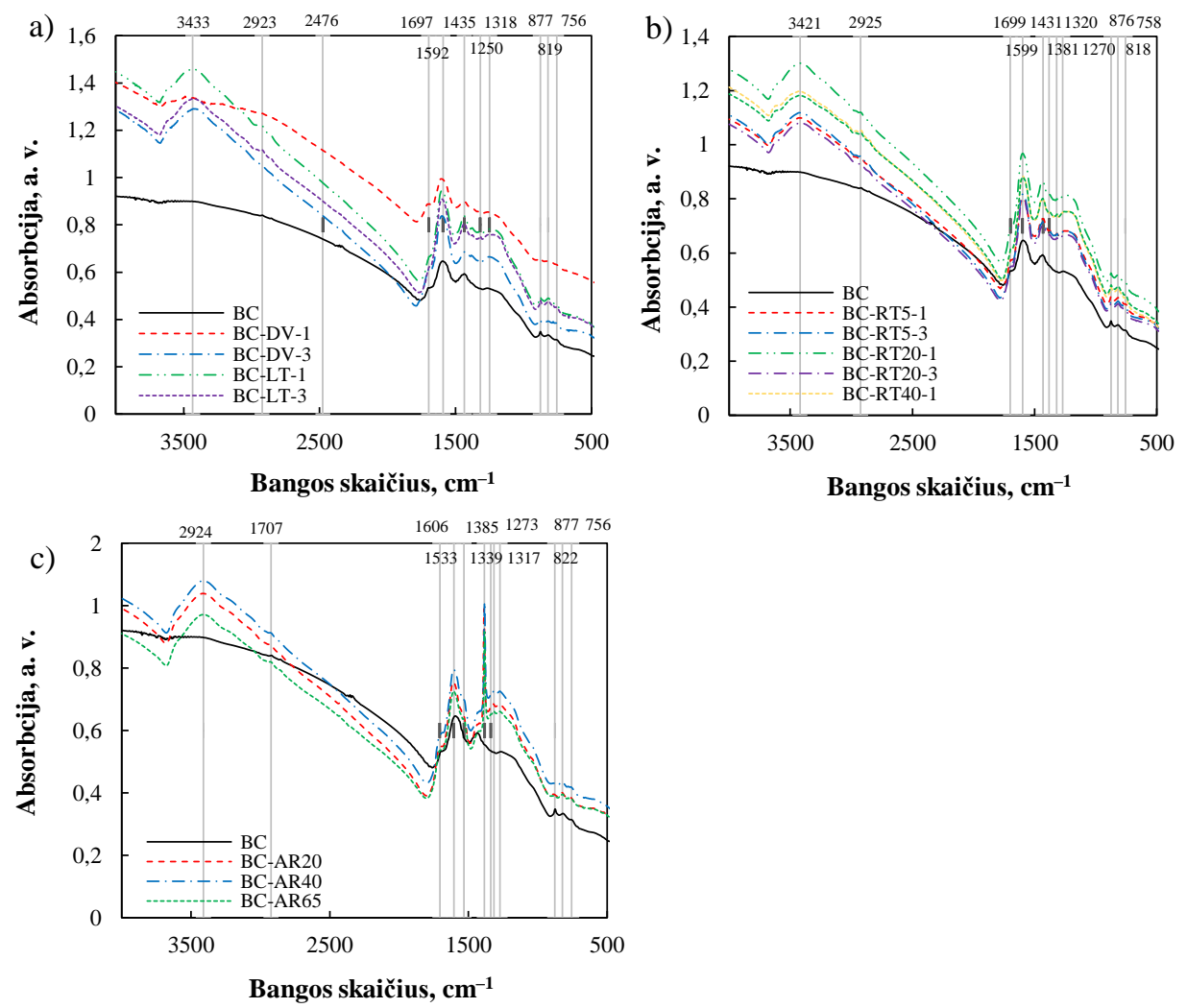

3.28 pav. Furjè transformacijos infraraudonujų spindulių spektrų paveikslai: a) nemodifikuotos, dejonizuoto ir lietaus vandens garais modifikuotos beržo žievès bioanglies; b) nemodifikuotos ir ramnolipidinio tirpalo $(5,20$ ir $40 \mathrm{mg} / \mathrm{l})$ garais modifikuotos bioanglies; c) nemodifikuotos ir azoto rūgštimi (20 \%, $40 \%$ ir $65 \%$ ) modifikuotos bioanglies, $n=2$

Fig. 3.28. Images of the Fourier-transform infrared spectra: a) unmodified birch bark biochar and modified by the steam of deionized water and rainwater, b) biochar unmodified and steam modified by rhamnolipid solution $(5,20$, and $40 \mathrm{mg} / \mathrm{l})$, c) biochar unmodified and modified by nitric acid solutions (20\%, $40 \%$ and $65 \%), n=2$ 
Panašiai Shim et al. (2015) ịvertino, kad drambliažolès ir garais aktyvintos bioanglies FTIR spektruose atsirado pikai ties $3000-3700 \mathrm{~cm}^{-1}$ ( $-\mathrm{OH}$ grupè), 1695 ir $1696 \mathrm{~cm}^{-1}(\mathrm{C}=\mathrm{O}), 1605$ ir $1616 \mathrm{~cm}^{-1}(\mathrm{C}=\mathrm{C}$ aromatinès jungtys). Pikai ties $1384 \mathrm{~cm}^{-1}$ ir $887-823 \mathrm{~cm}^{-1}(-\mathrm{CH})$ taip pat buvo nustatyti abiejų bioanglies tipu spektruose. Šie rezultatai rodo, kad funkcinès grupès bioanglyje nèra pašalinamos po jos fizikinès modifikacijos garais. Kitu tyrimu (Nguyen et al., 2019) nustatyta, kad funkcinių $\mathrm{O}-\mathrm{H}, \mathrm{C}-\mathrm{H}$, aromatinių $\mathrm{C}=\mathrm{C}, \mathrm{C}=\mathrm{O}, \mathrm{C}-\mathrm{O}$ ir aromatinių $\mathrm{C}-\mathrm{H}$ grupių reikšmingai padaugèjo po bioanglies modifikacijos $\mathrm{HNO}_{3}$. Pikas ties 3200$3650 \mathrm{~cm}^{-1}$ žymi -OH grupę, kylančią iš fenolių, alkoholių ir vandens. Bioanglies paviršiaus ploto ir funkcinių grupių kiekio padidejjimas po jos modifikacijos rūgštimis buvo nustatytas ir kitais tyrimais (Yakout et al., 2015). Remiantis Sahin et al. (2017) tyrimu, kai bioanglis buvo modifikuota azoto ir fosforo rūgščių tirpalais, ji buvo papildyta fosfatais, azoto grupemis ir nitratais, kuriuos parodè FTIR spektrai. Buvo nustatyti trys reikšmingi pikai: $\mathrm{N}=\mathrm{O}$ vibracijos ties 1340 $1350 \mathrm{~cm}^{-1}$ ir $\mathrm{C}=\mathrm{O}, \mathrm{C}=\mathrm{C}$ bei $\mathrm{C}=\mathrm{N}$ vibracijos ties $1600-1650 \mathrm{~cm}^{-1}$. Šie signalai siejasi su nitratais, karboksilinèmis $(-\mathrm{COOH})$, karbonilinemis $(\mathrm{C}=\mathrm{O})$ ir iminų $(\mathrm{C}=\mathrm{N})$ jungtimis bioanglies struktūroje.

Bioanglies porų charakteristikos buvo ivertintos naudojantis azoto adsorbcija. Modifikuotos bioanglies $\mathrm{N}_{2}$ adsorbcijos-desorbcijos izotermès bei porų dydžio pasiskirstymai pavaizduoti 3.29 ir 3.30 paveiksluose. Remiantis IUPAC klasifikacija, garais modifikuotos bioanglies adsorbcijos-desorbcijos izotermès gali būti klasifikuojamos kaip I tipo (3.29a ir 3.29b pav.), o azoto rūgštimi modifikuotos bioanglies - kaip II tipo (3.29c pav.). I tipo izotermès rodo, kad bioanglies tipai pasižymi mikroporinga struktūra, o II tipo - makroporinga. Bioanglies izotermių kilimas ties santykiniu slègiu $\left(\mathrm{P} / \mathrm{P}_{0}\right)$ tarp 0,1 ir 0,9 rodo mikroporingos ir mezoporingos struktūros egzistavimą.

3.30 paveiksle porų dydis apskaičiuotas BJH metodu. Didžiausi pikai visų bioanglies tipų atvejais siekè ties $3,1-6,6 \mathrm{~nm}$ dydžio poromis ir tai rodo mezoporų tūrio padidejjimą. Pikas ties $60,5 \mathrm{~nm}$ porų dydžiu buvo nustatytas azoto rūgštimi (65\%) modifikuotos bioanglies, o tai rodo makroporų buvimą. Nemodifikuotos bioanglies atveju buvo nustatyti pikai ties $6,36,16,9$ ir $60,5 \mathrm{~nm}$ porų dydžiu, kas rodo mezoporingą ir mikroporingą bioanglies struktūrą. Platus porų dydžio pasiskirstymas ir nežymiai heterogeniškos struktūros buvo nustatytos modifikuotuose bioanglies tipuose. Lyginant su nemodifikuota bioanglimi, jos poveikis garais ir azoto rūgštimi lèmè mezoporingesnès struktūros susikūrimą dèl siauro monomodalinio porų dydžio pasiskirstymo ties mezoporų dydžiu (2$50 \mathrm{~nm}$ ). Akivaizdu, kad bioanglis pasižymėjo plačiu porų dydžio pasiskirstymu nuo siaurų mikroporų iki platesnių mezoporų ir mikroporų. Skirtingi bioanglies modifikacijos būdai gali labai paveikti jos porų charakteristikas. Detalus porų struktūros charakterizavimas gali padèti efektyviai prognozuoti bioanglies potencialų poveikị dirvožemio gerinimui ir teršalų sorbcijai. 
a)

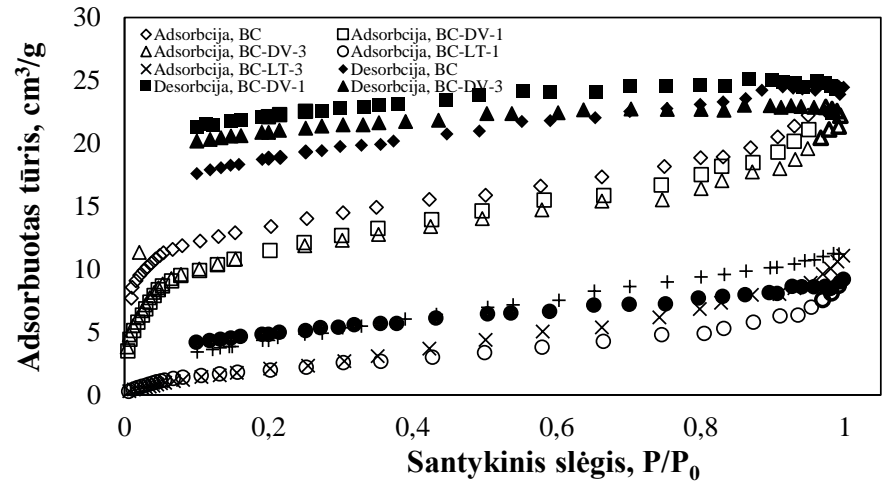

b)

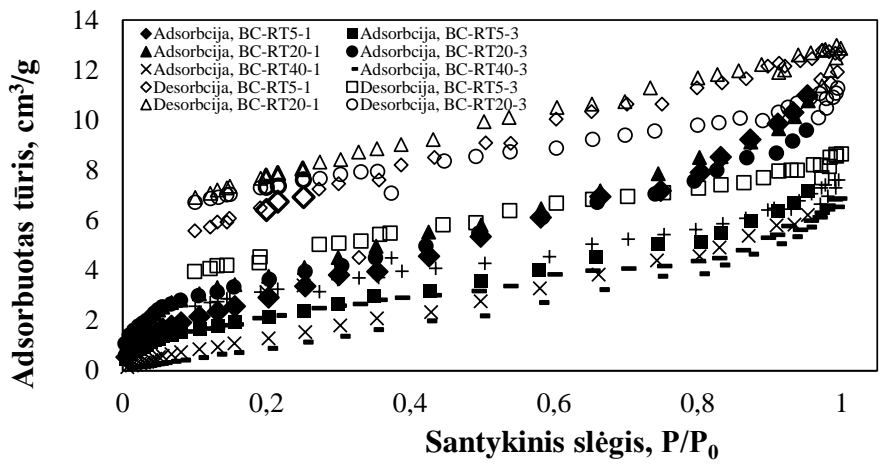

c)

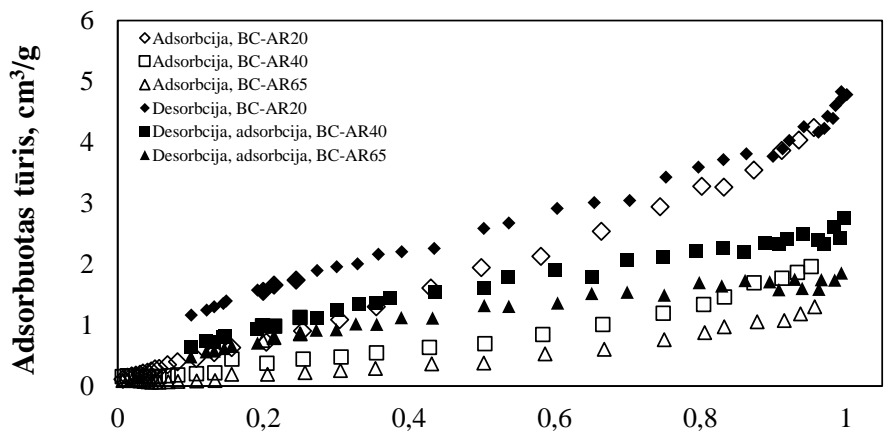

Santykinis slègis, $\mathbf{P} / \mathbf{P}_{0}$

3.29 pav. Azoto adsorbcijos-desorbcijos izotermès: a) nemodifikuotos ir modifikuotos dejonizuoto ir lietaus tirpalo garais bioanglies; b) nemodifikuotos ir modifikuotos ramnolipidinio tirpalo $(5,20$ ir $40 \mathrm{mg} / \mathrm{l})$ garais bioanglies; c) nemodifikuotos ir modifikuotos azoto rūgštimi (20, 40 ir $65 \%)$ bioanglies

Fig. 3.29. Nitrogen adsorption-desorption isotherms: a) unmodified and modified biochar by the steam of deionized and rain water; b) unmodified and modified biochar by the steam of rhamnolipid solution $(5,20$ and $40 \mathrm{mg} / \mathrm{l})$ steam; c) unmodified and modified biochar by nitric acid solutions (20,40 and 65\%) 
a)

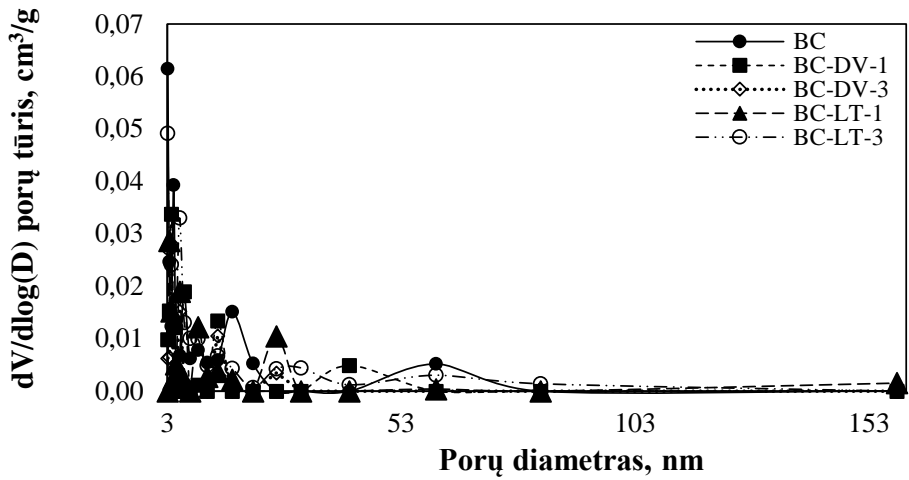

b)

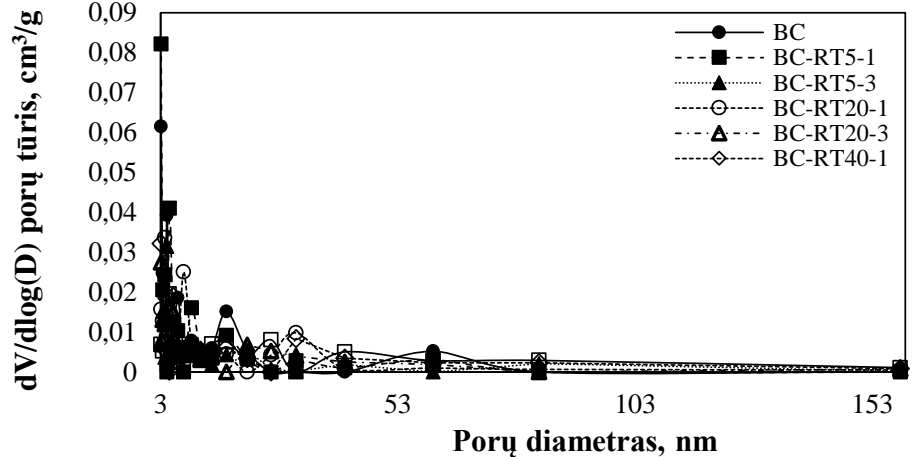

c)

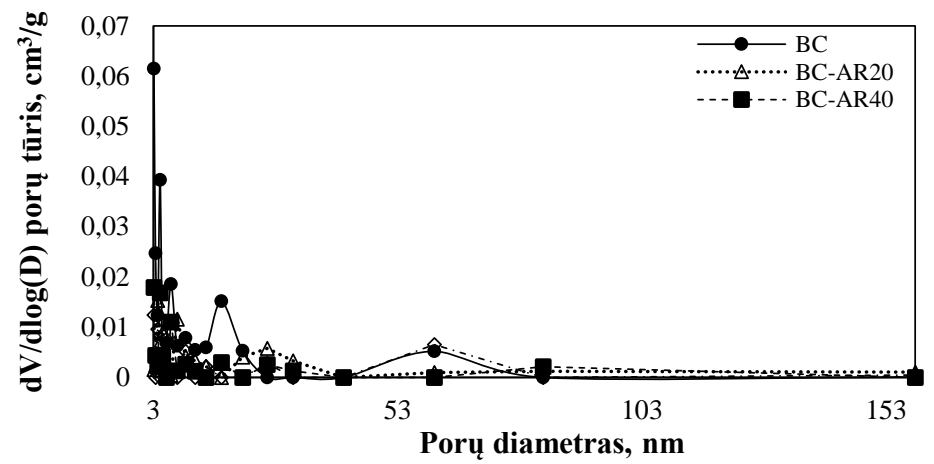

3.30 pav. Porų dydžio pasiskirstymas: a) nemodifikuotos ir modifikuotos bioanglies dejonizuoto ir lietaus tirpalo garais; b) nemodifikuotos ir modifikuotos bioanglies ramnolipidinio tirpalo $(5,20$ ir $40 \mathrm{mg} / \mathrm{l})$ garais; c) nemodifikuotos ir modifikuotos bioanglies azoto rūgšties tirpalu (20, 40 ir $65 \%)$

Fig. 3.30. Pore size distribution: a) biochar unmodified and modified by steam of deionized and rain water, $b$ ) biochar unmodified and modified by steam of rhamnolipid solutions $(5,20$, and $40 \mathrm{mg} / \mathrm{l})$, c) biochar unmodified and modified by nitric acid solutions $(20,40,65 \%)$ 
Fizikinis adsorbcijos procesas yra veikiamas bioanglies porų struktūros ir ji gali skirtis (Li et al., 2017). Vidutinis bioanglies tipų porų dydis varijavo nuo 1,93 iki 2,77 nm, kuris siejasi su mikroporinga ir mezoporinga struktūra (3.12 lentelè). Modifikuotos tirpalu garais bioanglies paviršiaus plotas padidèjo, o bendrasis porų tūris sumažèjo. Iš visų tirpalų garų didžiausią efektyvumą bioanglies paviršiaus ploto didejjimui turèjo ramnolipidinis tirpalas $(20 \mathrm{mg} / \mathrm{l})-15,2 \mathrm{~m}^{2} / \mathrm{g}$. Bioanglies tipai pagal SPP rikiuojasi tokia tvarka: BC-RT20-1 $\left(15,2 \mathrm{~m}^{2} / \mathrm{g}\right)<\mathrm{BC}-$ LT-1 $\left(10,4 \mathrm{~m}^{2} / \mathrm{g}\right)<$ BC $\left(4,42 \mathrm{~m}^{2} / \mathrm{g}\right)<\mathrm{BC}-\mathrm{DV}-1\left(3,95 \mathrm{~m}^{2} / \mathrm{g}\right)$. Galima teigti, kad mikroporingiausi bioanglies tipai buvo tie, kurie buvo modifikuoti $5 \mathrm{mg} / \mathrm{l}$ (3 val.) ir $20 \mathrm{mg} / \mathrm{l}$ (1 val.) ramnolipidiniu tirpalu, nes viso paviršiaus ploto mikroporų plotas sudare atitinkamai 98 ir $95 \%$. Modifikuotų garais bioanglies tipų bendrasis porų tūris varijavo nuo 0,0089 iki $0,035 \mathrm{~cm}^{3} / \mathrm{g}$, o modifikuotų azoto rūgštimi nuo 0,0026 iki $0,0063 \mathrm{~cm}^{3} / \mathrm{g}$.

3.12 lentelè. Nemodifikuotų ir modifikuotų bioanglies tipų paviršiaus struktūros charakteristikos

Table 3.12. Characteristics of the surface structure of unmodified and modified biochar types

\begin{tabular}{|l|l|l|l|l|l|}
\hline $\begin{array}{c}\text { Bioanglies } \\
\text { modifikacijos } \\
\text { būdas }\end{array}$ & $\begin{array}{c}|c| \\
\text { peviršiaus } \\
\text { plotas, } \\
\mathrm{m}^{2} / \mathrm{g}\end{array}$ & $\begin{array}{c}\text { Mikroporu } \\
\text { paviršiaus } \\
\text { plotas, } \mathrm{m}^{2} / \mathrm{g}\end{array}$ & $\begin{array}{c}\text { Bendrasis } \\
\text { poru tūris, } \\
\mathrm{cm}^{3} / \mathrm{g}\end{array}$ & $\begin{array}{c}\text { Mikroporu } \\
\text { tūris, } \mathrm{cm}^{3} / \mathrm{g}\end{array}$ & $\begin{array}{c}\text { Vidutinis } \\
\text { poru } \\
\text { dydis, } \mathrm{nm}\end{array}$ \\
\hline BC & 4,42 & 1,29 & 0,035 & 0,0216 & 1,93 \\
\hline BC-DV-1 & 3,95 & 2,31 & 0,035 & 0,0194 & 1,93 \\
\hline BC-DV-3 & 3,81 & 0,88 & 0,032 & 0,0186 & 1,93 \\
\hline BC-LT-1 & 10,4 & 8,27 & 0,013 & 0,00368 & 1,93 \\
\hline BC-LT-3 & 9,68 & 7,8 & 0,016 & 0,00278 & 2,02 \\
\hline BC-RT5-1 & 12,9 & 11,7 & 0,019 & 0,00415 & 1,93 \\
\hline BC-RT5-3 & 8,81 & 8,66 & 0,0313 & 0,012 & 1,93 \\
\hline BC-RT20-1 & 15,2 & 14,4 & 0,018 & 0,0054 & 1,93 \\
\hline BC-RT20-3 & 14,7 & 13,3 & 0,016 & 0,00522 & 1,93 \\
\hline BC-RT40-1 & 6,78 & 5,13 & 0,01 & 0,00182 & 2,02 \\
\hline BC-RT40-3 & 6,15 & 2,61 & 0,0089 & 0,000929 & 2,02 \\
\hline BC-AR20 & 4,36 & 2,31 & 0,0063 & 0,000821 & 2,02 \\
\hline BC-AR40 & 1,99 & 0,75 & 0,0037 & 0,000268 & 2,77 \\
\hline BC-AR65 & 1,27 & 0,28 & 0,0026 & 0,000101 & 2,77 \\
\hline
\end{tabular}


Kitu tyrimu (Yakout 2015) panašiai nustatyta, kad po poveikio azoto rūgštimi, ryžių šiaudų bioanglies SPP taip pat sumažèjo nuo 76,2 iki $68,8 \mathrm{~m}^{2} / \mathrm{g}$. Mikroporu paviršiaus plotas sumažèjo vykstant rūgšties poveikiui (nuo 52,8 iki $33,2 \mathrm{~m}^{2} / \mathrm{g}$ ) dèl didelès dalies deguonies turinčių funkcinių grupių, kurios trukdo azoto molekulèms patekti i porų vidų. Buvo pastebėtas reikšmingas porų skersmens padidejjimas $\mathrm{HNO}_{3}$ atveju nuo 1,6 iki 2,4 $\mathrm{nm}$. Tai rodo, kad nemodifikuotos bioanglies poveikis rūgštimis lemia mikroporų suirimą, kurios formuoja mezoporas ir didina porų skersmeni. Taip pat mikroporu procentinè frakcija sumažejo $\mathrm{HNO}_{3}$ atveju (nuo 53 iki $28 \%$ ), o mezoporų frakcija padidejo (nuo 47 iki $72 \%$ ). Bioanglies SPP sumažejimas $\mathrm{HNO}_{3}$ atveju buvo aiškinamas mikroporų tūrio sumažèjimu. Bioanglies poveikis rūgštimi lèmè porų išplatèjimą, suardant porų sieneles ir suardant porų struktūrą, taip mažinant jos paviršiaus plotą. Panašiai Guzel et al. (2017) nustatè, kad oksiduotos piktžolių bioanglies $\left(500{ }^{\circ} \mathrm{C}\right) \mathrm{SPP}$, bendrasis porų tūris ir porų skersmuo sumažèjo didejjant $\mathrm{HNO}_{3}$ koncentracijai nuo 20 iki $65 \%$ atitinkamai nuo $25,6 \mathrm{iki} 5,14 \mathrm{~m}^{2} / \mathrm{g}$, nuo 0,019 iki $0,006 \mathrm{~cm}^{3} / \mathrm{g}$ ir nuo 3,74 iki $3,57 \mathrm{~nm}$. Šis sumažejjimas aiškinamas porų susiaurejjimu, deguonies grupių susiformavimu arba porų sienelių destrukcija ir mikroporų bei mezoporų konversija ị makroporas dèl stiprių oksidacinių sąlygų.

Taigi, vertinant skirtingas modifikacijas, matyti, kad $20 \mathrm{mg} / \mathrm{l}$ koncentracijos ramnolipidinio tirpalo garai turèjo didžiausią poveikį didesniam bioanglies SPP vystymuisi, kuris po 1 val. trukmès poveikio siekè $15,2 \mathrm{~m}^{2} / \mathrm{g}$. Panašiai dèl minètos modifikacijos susidare didžiausias bioanglies mikroporų paviršiaus plotas $14,4 \mathrm{~m}^{2} / \mathrm{g}$. Tai rodo, kad šio modifikuoto bioanglies tipo didžiają dali porų sudaré mikroporos (iki $95 \%$ mikroporu plotas sudarè bendrojo ploto). Bioanglies paviršiaus plotas yra didelis dèl mikroporingos struktūros, kuri teikia geras sąlygas teršalų adsorbcijai bei mikroorganizmams išgyventi biofiltre.

\subsection{Modifikuotos bioanglies ịtaka lakiụjų teršalų šalinimo efektyvumo didinimui biofiltre}

Yra siūloma, kad hidrofiliška bioịkrova yra tinkama polinių junginių šalinimo efektyvumui didinti. Šiame tyrime buvo pasirinkta hidrofiliška smulkios frakcijos pušies medienos bioanglis, modifikuota vidutinès koncentracijos $(20 \mathrm{mg} / \mathrm{l})$ ramnolipidinio tirpalo garais, nes tokia modifikacija lèmè didesnio paviršiaus ploto ir mikroporingumo formavimąsi, gausesnes deguonies turinčias funkcines grupes, svarbias vandens adsorbcijai ant bioanglies paviršiaus. Tyrimo tikslas įvertinti hidrofiliškos bioanglies įtaką skirtingo poliškumo lakiųjų organinių ir neorganinių junginių šalinimo efektyvumui. Geresnis junginių šalinimo efektyvumas modifikuotos bioanglies atveju buvo susietas su didesniu bioịkrovos 
drègmès kiekiu (iki 10 procentinių vienetų), santykiniu oro drègniu (iki $8 \%$ ) bei vidutiniu oro greičiu $(0,32 \mathrm{~m} / \mathrm{s})$.

Remiantis 3.31 paveikslu, didelis oro valymo nuo acetono efektyvumas gali būti pasiektas iš karto praejus 14 dienų po bioịkrovos aktyvinimo. Nuo 1 iki 5 eksperimento dienos po aktyvinimo acetono garu pašalinimo efektyvumas biofiltre, užpildytame nemodifikuota bioanglimi ir plaušu, varijavo nuo 68,2 iki $83,8 \%$, kai vidutinis oro srauto greitis sieke $0,37 \mathrm{~m} / \mathrm{s}$. Tai galima sieti su potencialiu bakterijų skaičiaus didejjimu (Baltrènas, Mačaitis, 2014). Šiame tyrime pradine acetono koncentracija kito nuo $277 \mathrm{iki} 356 \mathrm{mg} / \mathrm{m}^{3}$. Santykinis drègnis šio eksperimento metu buvo išlaikytas 57-91,6\%, o bioịkrovos drégmès kiekis - 57-61,8\%.

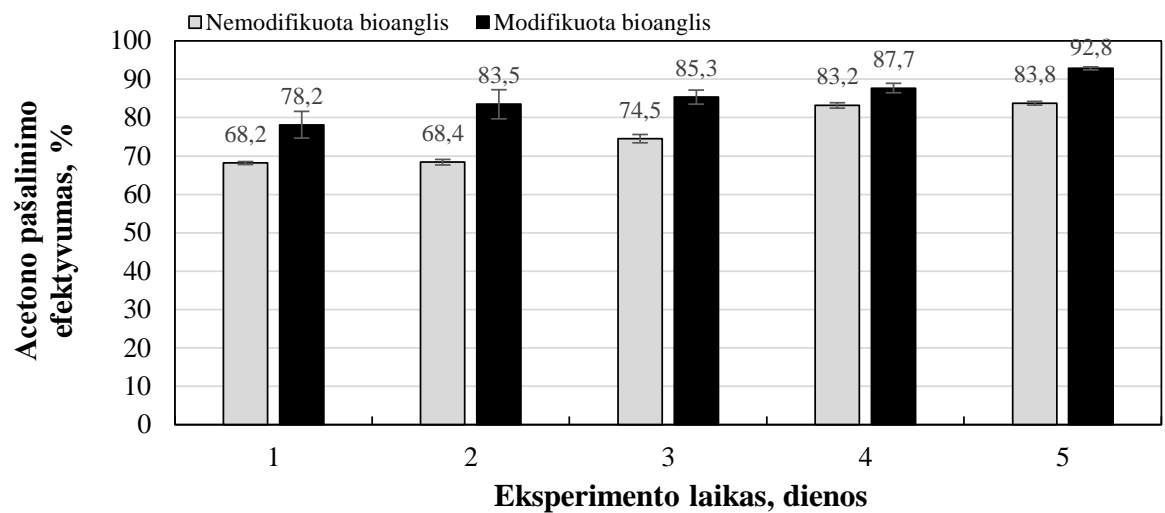

3.31 pav. Acetono valymo efektyvumo priklausomybé nuo laiko biofiltre, užpildytame nemodifikuotos ir modifikuotos bioanglies bei plaušo mišiniais, $n=3$

Fig. 3.31. Time dependence of acetone cleaning efficiency in a biofilter filled with a mixture of unmodified and modified biochar and fiber mixtures, $n=3$

Remiantis 3.31 paveikslu, kuriame rodomas biofiltro, užpildyto garais modifikuotos bioanglies ir plaušo mišiniu, efektyvumas naudojant acetoną, matyti, kad pašalinimo efektyvumas per 1-5 dienų siekè 78,2-92,8 \%, o tai buvo 4,53-15,1\% daugiau, lyginant su nemodifikuota bioanglimi, kai vidutinis oro srauto greitis biofiltre siekè $0,32 \mathrm{~m} / \mathrm{s}$. Šiame tyrime pradinè acetono koncentracija siekè $291-316 \mathrm{mg} / \mathrm{m}^{3}$. Galima teigti, kad bioanglies modifikacija ramnolipidinio tirpalo garais reikšmingai padidino (iki $9 \%$ ) acetono valymo efektyvumą biofiltre su savaiminiais mikroorganizmais. Tai galima sieti su geresnemis biofiltro oro drègmès sąlygomis ir didesniu (iki 9,7 \%) bioịkrovos drègmès kiekiu. Santykinis oro drègnis šio eksperimento metu buvo išlaikytas 50,2-99,9\%, o bioịkrovos drègmès kiekis -66,7-69,2\%. Remiantis kitu tyrimu (Baltrėnas et al., 2015) buvo gautas panašus acetono valymo efektyvumas, kuris siekẻ nuo 70 iki $90 \%$, kai 
buvo taikomas tiesios konstrukcijos plokščiu biofiltras su medienos plaušo bioịkrova. Minètame tyrime didžiausias acetono išvalymo efektyvumas $(90,3 \%)$ gautas, kai acetono koncentracija siekè $300 \mathrm{mg} / \mathrm{m}^{3}$, o oro srauto greitis $-0,08 \mathrm{~m} / \mathrm{s}$.

Buvo nustatyta, kad ksileno pašalinimo efektyvumas biofiltre su nemodifikuotos bioanglies įkrova po 5 dienų buvo mažesnis nei acetono ir sieké $68,9 \%$, kai vidutinis oro srauto greitis bioịkrovoje buvo $0,37 \mathrm{~m} / \mathrm{s}$ (3.32 pav.). Prastesni ksileno bioskaidymą, lyginant su acetonu, galima sietu su didesne jo Henrio konstanta $\left(\mathrm{K}_{\mathrm{H}}, 7,18 \cdot 10^{-3} \mathrm{~atm}-\mathrm{m}^{3} / \mathrm{mol}\right)$, kuri parodo dujų tirpumo vandenyje lygi. Hidrofobiniai junginiai, turintys aukštą $\mathrm{K}_{\mathrm{H}}$, pasižymi ribota masès pernaša dèl vandens sluoksnio, supančio bioplèvelę, pasipriešinimo. Kiti tyrimai taip pat parodé, kad LOJ bioskaidymas biofiltruose yra stipriai veikiamas Henrio konstantos. Deshusses and Johnson (2000) tyre 18 LOJ biofiltre 48 valandoms ir padare išvadą, kad LOJ junginių bioskaidymas stipriai priklause nuo jų prieinamumo arba $\mathrm{K}_{\mathrm{H}}$ bei hidrofobiškumo (oktanolio / vandens pasiskirstymo). Panašiai buvo nustatyta, kad junginius su aukštomis $K_{H}$ biofiltruose yra sunku pašalinti. Ksileno bioskaidymą taip pat riboja jo toksiškumas (Morgado et al., 2004). Pradinè ksileno koncentracija šiame tyrime siekè nuo 314 iki 371 mg/m³.

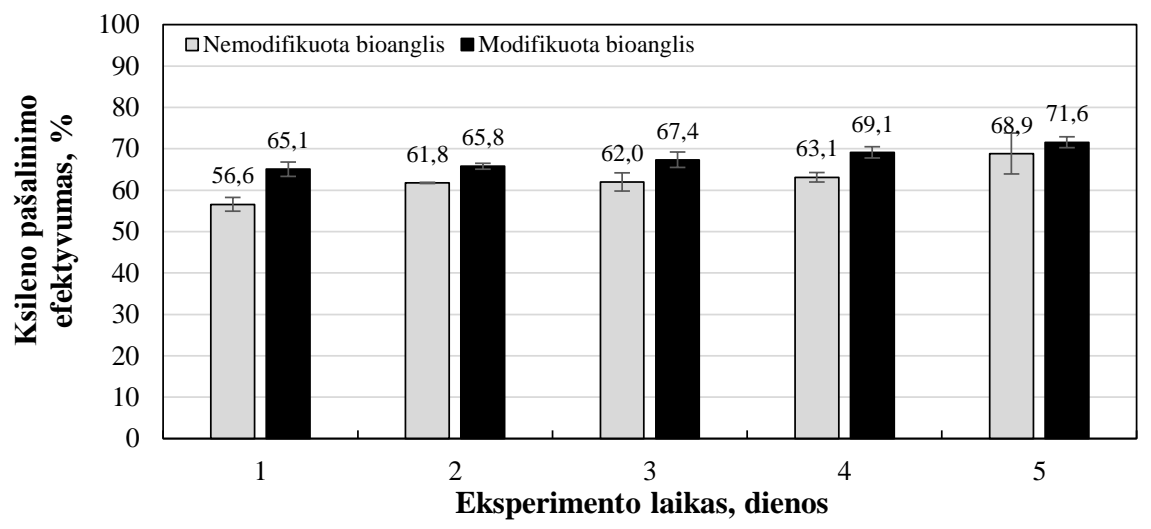

3.32 pav. Ksileno valymo efektyvumo priklausomybė nuo laiko biofiltre, užpildytame nemodifikuotos ir modifikuotos bioanglies bei plaušo mišiniais, $n=3$

Fig. 3.32. Time dependence of xylene cleaning efficiency in a biofilter filled with a mixture of unmodified and modified biochar and fiber mixtures, $n=3$

Biofiltro, užpildyto garais modifikuotos bioanglies atveju, ksileno šalinimo efektyvumas sieke $65,1-71,6 \%$ ir buvo iki 8,5 procentinių vienetų didesnis lyginant su nemodifikuotos bioanglies bioịkrova. Tai galima sieti su geresnèmis drėgmès sulaikymo sąlygomis biofiltre bei geresniu grybų išsivystymu. Kitame tyrime (Baltrènas, Mačaitis, 2014) maksimalus ksileno pašalinimo efektyvumas siekė $87,9 \%$ biofiltre su poringomis polimerinėmis plokštelèmis ir beržo skaidulų 
bioịkrova bei kapiliarine drèkinimo sistema. Morgado et al. (2004) nustatè, kad iš trijų tirtų medžiagų (durpių, medienos pjuvenų ir granulinès bazaltinès uolienos $\left(40-50 \% \mathrm{SiO}_{2}\right)$ durpès pasižymėjo geriausiu poveikiu m-ksileno šalinimui iš oro biofiltracijos būdu. Durpès pasižymèjo $52 \%$ drègmès kiekiu, kuris puikiai tiko oro biofiltracijos procesui.

Biologinis ksileno valymas vyksta dèl dviejų fenomenų: 1) fizikinio ir cheminio, kuris lemia masès pernašą iš dujų i skysčio fazę (bioplèvelę), kurioje vystosi biomasé; 2) biologinio, kuris atsakingas už ksileno oksidaciją mikroorganizmuose (Morgado et al., 2004). Remiantis LOJ šalinimu biofiltruose, yra pirmoji dominantinè adsorbcijos proceso fazė, kurios metu teršalų pašalinimo efektyvumas yra mažesnis dèl adsorbcinès gebos prisotinimo bei mikroorganizmų prisitaikymo periodo (Colon et al., 2009). Ilgainiui biofiltro valymo efektyvumas didejja dèl bioskaidymo dominavimo.

Biofiltro valymo efektyvumas amoniako atveju reikšmingai padidejo po 5 eksperimento dienų ir sieké nuo 68,5 iki 78,8\% (3.33 pav.). Nemodifikuotos bioanglies ir plaušo bioịkrovos atveju acetono ir amoniako maksimalus išvalymo efektyvumas buvo panašus (atitinkamai $83,8 \%$ ir 78,8 \%). Tai būtų galima aiškinti šių teršalų panašiomis $\mathrm{K}_{\mathrm{H}}$ (atitinkamai $1,87 \cdot 10^{-5}$ ir $1,61 \cdot 10^{-5} \mathrm{~atm}-\mathrm{m}^{3} / \mathrm{mol}$ ). 4 ir 5 eksperimento dieną amoniako pašalinimo efektyvumas buvo pastovus ir siekè 78,6 ir $78,8 \%$.

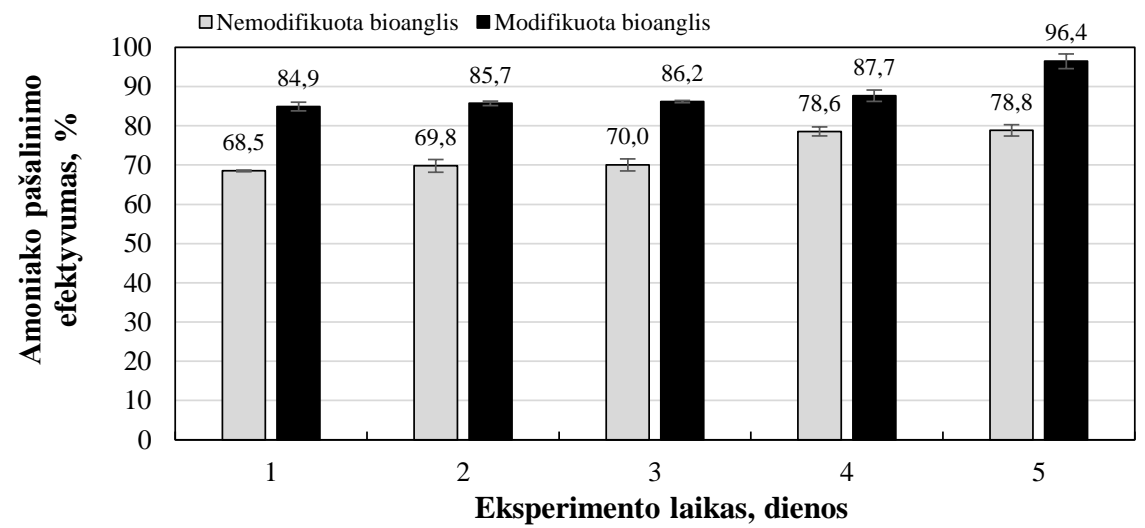

3.33 pav. Amoniako valymo efektyvumo priklausomybè nuo laiko biofiltre, užpildytame nemodifikuotos ir modifikuotos bioanglies bei plaušo mišiniais, $n=3$

Fig. 3.33. Time dependence of ammonia cleaning efficiency in a biofilter filled with a mixture of unmodified and modified biochar and fiber mixtures, $n=3$

Biofiltro, užpildyto modifikuotos bioanglies ir plaušo mišiniu, efektyvumas buvo didesnis ir kito nuo 84,9 iki 96,4\%. Modifikuotos bioanglies atveju amoniako šalinimo efektyvumas buvo didesnis nei nemodifikuotos (iki 
17,6 procentinių vienetu). Pradinè amoniako koncentracija kito nuo 264 iki $273 \mathrm{mg} / \mathrm{m}^{3}$. Atliekant kitą tyrimą (Zhang et al., 2008) buvo gautas $80-100 \%$ amoniako šalinimo efektyvumas biofiltre su ceolito ir tuopų pjuvenų bioịkrova, esant ịvairioms amoniako pradinems koncentracijoms. Remiantis Gabriel et al. (2007) tyrimu, amoniako šalinimo efektyvumas kokoso pluošto bioịkrovos atveju siekè nuo 30 iki $100 \%$. Šie autoriai teigia, kad sausos zonos biofiltre lemia mažesni amoniako pašalinimo efektyvumą.

Taigi, ramnolipidinio tirpalo garais modifikuota bioanglis gali efektyviai šalinti acetoną, ksileną ir amoniaką esant atitinkamai 93\%, 72\% ir $96 \%$ pašalinimo efektyvumams. Reikšmingai didesnis pašalinimo efektyvumas (iki 17,6 procentiniu vienetų) stebètas amoniako atveju. Galima teigti, kad garais modifikuota bioanglis yra efektyvesnè šalinant lakiuosius neorganinius polinius junginius, lyginant su organiniais poliniais ir nepoliniais junginiais. Modifikuota bioanglis pasižymėjo iki 8 procentinių vienetų didesniu drègmès kiekiu (67\%), kuris gali būti aiškinamas didesniu vidutiniu porų spinduliu $(22 \mu \mathrm{m})$. Kai kapiliaro (poros) spindulys yra didesnis, kapiliarinis procesas yra greitesnis. Prastesni ksileno šalinimo efektyvumą, lyginant su kitais junginiais, galima sieti su jo nepoliškumu ir didesne Henrio konstanta $\left(7,18 \cdot 10^{-3} \mathrm{~atm}-\mathrm{m}^{3} / \mathrm{mol}\right)$.

\subsection{Trumpalaikẻ bioanglies geba didinti rudžemio drèkumą}

Tyrimo tikslas - ịvertinti, ar bioanglies norma, tręšimas ir žemès dirbimas bei data veikia dirvožemio funkcijas. Tyrimo uždaviniai: 1) įvertinti dirvožemio, pagerinto bioanglimi, cheminių ir hidrofizikinių savybių pokyčius priklausomai nuo minètų veiksnių; 2) nustatyti ryši tarp pagerinto dirvožemio drèkumo, susieto su jos hidrofilinèmis funkcinèmis grupėmis bei kitomis jo savybėmis. Tikètina, kad hidrofobinè bioanglis neturès poveikio dirvožemio drèkumo pokyčiams dèl išorinių veiksnių poveikio (vèjo, kritulių) ir daugiau organinès medžiagos turintis dirvožemis turès mažiau hidroksilinių funkcinių grupių.

Pušies medienos bioanglis pasižymèjo dideliu hidrofobiškumu (VLSL $=1810 \mathrm{~s}$ ), kuris buvo didesnis nei beržo medienos ar kanapių bioanglies (3.34a pav.). Šio tyrimo labai hidrofobiškos bioanglies buvo mažas SPP $\left(2,77 \mathrm{~m}^{2} / \mathrm{g} ; 3.34 \mathrm{~d}\right.$ pav.), mažas O kiekis (3,39\%; 3.34f pav.), didelis peleningumas $(16,6 \% ; 3.34 \mathrm{~b}$ pav. $)$, didelis elektrinis laidis $(8,28 \mu \mathrm{s} / \mathrm{cm}$; $3.34 \mathrm{c}$ pav.), didesnis $\mathrm{C}$ kiekis $(88,7 \%$; 3.34e pav.), nežymiai didesnis $\mathrm{pH}(8,53$; 3.13 lentelè), palyginus su nežymiai hidrofobiškais beržo medienos ir kanapių bioanglies tipais. Šio tyrimo bioanglies dideli hidrofobiškumą galima sieti su palyginti didesniu pelenų kiekiu, kuris blokuoja porų erdvę ir neleidžia vandeniui prasiskverbti pro bioanglies paviršių. 

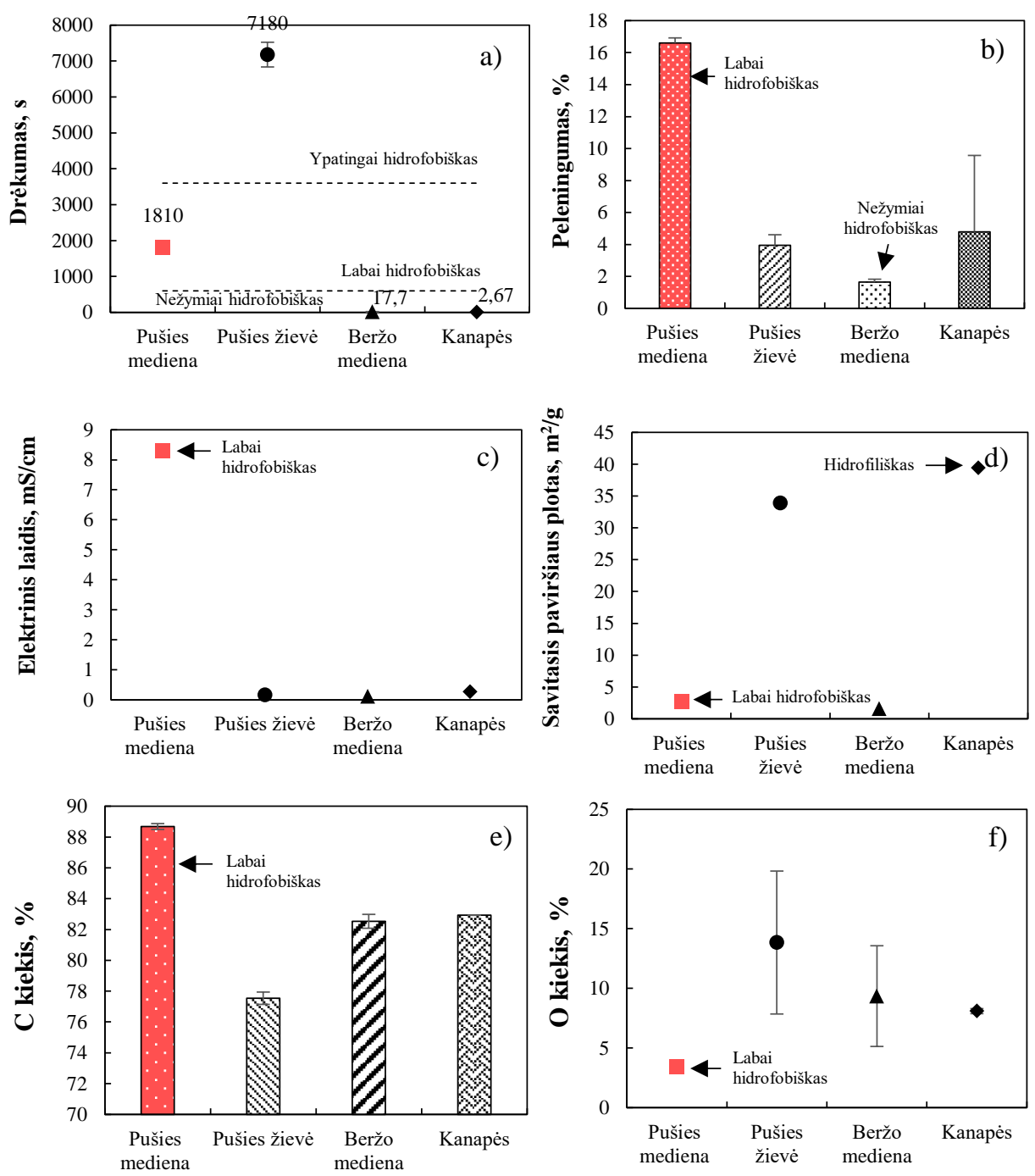

3.34 pav. Lignoceliuliozinès bioanglies $\left(450^{\circ} \mathrm{C}, 2\right.$ val.) fizikinių-cheminių savybių palyginimas: a) drèkumas, $\mathrm{s}$; b) peleningumas, $\%$; c) elektrinis laidis, $\mu \mathrm{s} / \mathrm{cm}$;

d) savitasis paviršiaus plotas, $\mathrm{m}^{2} / \mathrm{g}$; e) C kiekis, \%; f) O kiekis, $\%, n=3$

Fig. 3.34. Comparison of physico-chemical properties of lignocellulosic biochar ( $450{ }^{\circ} \mathrm{C}, 2$ hours): a) wettability, s; b) ash content, $\%$; c) electrical conductivity, $\mu \mathrm{s} / \mathrm{cm}$; d) specific surface area, $\mathrm{m}^{2} / \mathrm{g}$; e) C content, \%; f) O content, $\%, n=3$ 
3.13 lentelè. Pušies medienos žematemepratūrès $\left(450{ }^{\circ} \mathrm{C}\right)$ bioanglies fizikinès ir cheminès savybès, $n=3, \pm$ standartinis nuokrypis

Table 3.13. Physico-chemical properties of low-temperature biochar $\left(450^{\circ} \mathrm{C}\right)$ from pine wood, $n=3, \pm$ standard deviation

\begin{tabular}{|c|c|c|c|c|}
\hline $\mathrm{pH}_{\mathrm{KCl}}$ & $\begin{array}{c}\text { Vandens } \\
\text { laikomoji geba, } \\
\%\end{array}$ & $\mathrm{H}, \%$ & $\mathrm{~N}, \%$ & $\begin{array}{c}\text { Katijonu } \\
\text { mainų geba, } \\
\text { cmol } / \mathrm{kg}\end{array}$ \\
\hline $8,53 \pm 0,13$ & $449 \pm 8,08$ & $11,07 \pm 0,19$ & $0,25 \pm 0,006$ & $0,68 \pm 0,11$ \\
\hline
\end{tabular}

Bioanglies tipai su dideliu pradiniu peleningumu yra mažiau tinkami dirvožemiui gerinti dèl didelių potencialiai toksiškų elementų (PTE) kiekių, kurie gali sukelti dirvožemio taršą (Pituello et al., 2014). Tirta pušies medienos žematemperatūrè bioanglis atitiko standartinę kokybę, remiantis EBS penkių PTE atvejais: $\mathrm{Pb}$ koncentracija $(\mathrm{mg} / \mathrm{kg}$ ) buvo 3,83 karto mažesnè už standartinę bioanglies kokybę pagal didžiausią leidžiamają Pb koncentraciją $(150 \mathrm{mg} / \mathrm{kg})$, $\mathrm{Zn}-1,23$ karto mažesnè, $\mathrm{Cr}-8,39$ karto mažesnè, $\mathrm{Cu}-3,89$ karto mažesnè ir $\mathrm{Ni}-5,36$ karto mažesnè (3.35 pav.). Pagal Cd koncentraciją $(2,48 \mathrm{mg} / \mathrm{kg})$ tirta bioanglis neatitiko standartinès bioanglies kokybès pagal didžiausią leidžiamają koncentraciją (1,5 mg/kg) (3.35b pav.). Kai kurie tyrèjai nurodè, kad Zn, $\mathrm{Cu}$ ir $\mathrm{Pb}$ yra stabilizuojami bioanglyje. Dèl ilgalaikio bioanglies įterpimo ị dirvožemį ji turi būti gerai ištiriama dèl PTE, kurie gali kauptis dirvožemyje. Remiantis EBS, bioanglis negali viršyti PTE ribinių verčių, jei norima ją naudoti žemès ūkyje (Hilber et al., 2017).

a)

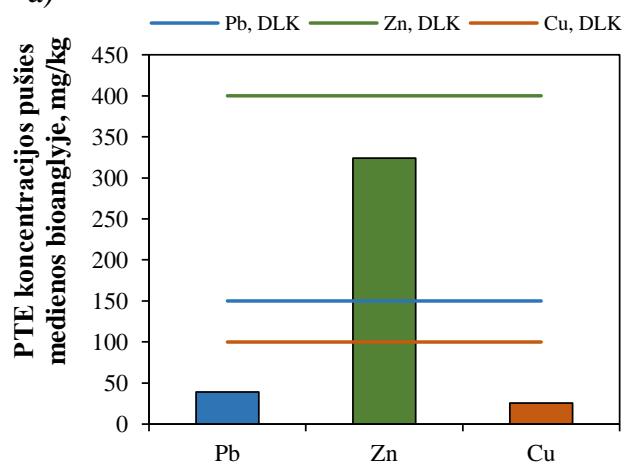

b)

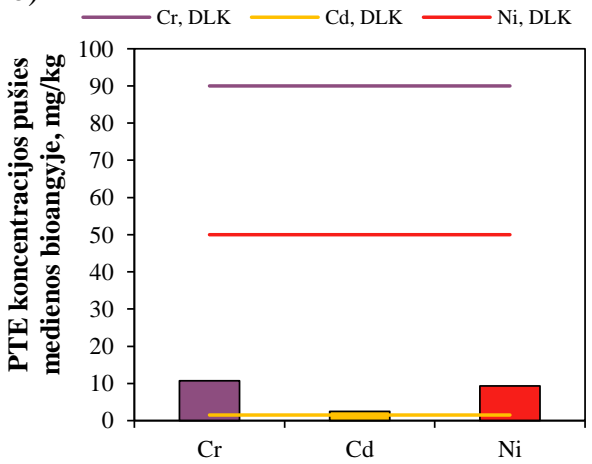

3.35 pav. Pušies medienos bioanglies potencialiai toksiškų elementų koncentracijos $(\mathrm{mg} / \mathrm{kg})$ : a) švino, cinko ir vario; b) chromo, kadmio ir nikelio, $n=3$

Fig. 3.35. Concentrations of potentially toxic elements in pine wood biochar $(\mathrm{mg} / \mathrm{kg})$ : a) lead, zinc, and copper; b) chromium, cadmium, and nickel, $n=3$ 
Tirta bioanglis pasižymėjo aštuoniais pikais FTIR grafike, kurie rodo tam tikrų funkcinių grupių buvimą jos struktūroje: alkoholinių $-\mathrm{OH}\left(3442 \mathrm{~cm}^{-1}\right)$, rūgštinių $\mathrm{C}=\mathrm{O}\left(1684 \mathrm{~cm}^{-1}\right)$, aromatinių $\mathrm{C}=\mathrm{C}\left(1684 \mathrm{~cm}^{-1}, 1584 \mathrm{~cm}^{-1}, 1429 \mathrm{~cm}^{-1}\right)$, anhidridinių C-O $\left(1174 \mathrm{~cm}^{-1}\right)$ ir aromatinių C-H $\left(805 \mathrm{~cm}^{-1}, 879 \mathrm{~cm}^{-1}, 752 \mathrm{~cm}^{-1}\right)$ (3.36 pav.). Neįterptos i dirvožemį bioanglies FTIR spektras parode stipriai kondensuotą anglies struktūrą be charakteringesnių pikų.

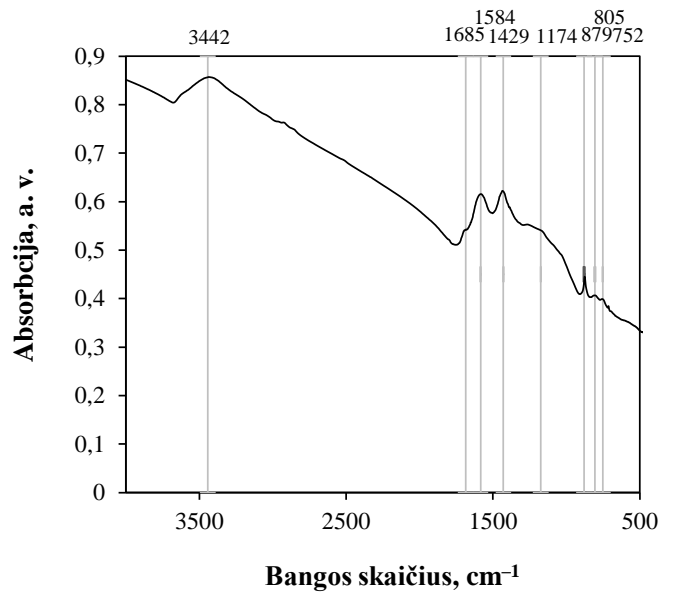

3.36 pav. Žematemepratūrès pušies medienos bioanglies Furjè transformacijos infraraudonųų spindulių spektras, $n=1$

Fig. 3.36. Fourier-transform infrared spectra of low-temperature pine wood biochar, $n=1$

Intensyvesni pikai buvo nustatyti ties $1584 \mathrm{~cm}^{-1}$ ir $1429 \mathrm{~cm}^{-1}$, kurie rodo didelio intensyvumo $\mathrm{C}=\mathrm{C}$ žiedų regioną (Abdulrazzaq et al., 2014). Tai rodo aromatingumo didejjimą pirolizès metu. Piko atsiradimas ties $879 \mathrm{~cm}^{-1}$ bangos skaičiumi siejamas su aromatinès $\mathrm{C}-\mathrm{H}$ grupès deformacijomis.

Remiantis vidutiniais viso eksperimento duomenimis, po 6 mèn. organinès medžiagos (OM) kiekis buvo 22,7 \% didesnis nei po 3 mèn. Vertinant vidutinius trečio ir šešto mènesių duomenis, tręšimas azoto, fosforo ir kalio (NPK) trąšomis sudare didesnị OM kiekị. Seklaus neariminio žemès dirbimo sistemoje tręšiant (S-2) OM kiekis buvo vidutiniškai 12,6 \% didesnis, nei netręšiant (S-1), o taikant tiesioginę sėją tręšimo (M-2) efektyvumas minimam rodikliui buvo didesnis, t. y. OM kiekis buvo vidutiniškai 41,9 \% didesnis, nei netręšiant (M-1). Vidutiniais viso eksperimento duomenimis ir nepriklausomai nuo žemès dirbimo ir tręšimo sistemos bei datos, 5 t/ha bioanglies norma OM kieki padidino 33,7 \%, o 15 t/ha net $58 \%$ (3.37 pav.), palyginti su variantais be bioanglies.

Eksperimento žemès dirbimo ir tręšimo sistemų sąveikos analizè atskleidè, kad, nepriklausomai nuo bioanglies naudojimo, per 3 mèn. laikotarpi $\mathrm{S}$ sistemoje 
OM kiekis padidejo 12,4-16,1 \%, o M sistemoje - iki 57,6 \%. Taigi, M taikymas buvo efektyvesnis OM kiekiui nei S dirbimas. Naudojant mineralines NPK trąšas, M sistemoje OM pokyčiai per 3 mèn. laikotarpị buvo didesni, nei jų nenaudojant ir siekè 57,6\%. Praejjus 3 mèn. nuo bioanglies iterpimo, 5 t/ha bioanglies norma OM kieki padidino 15,4\%, o 15 t/ha norma esmingai, t. y. $40 \%$. Praejus 6 mèn. po bioanglies iterpimo, OM kiekis visais variantais buvo $2,1-34,1 \%$ didesnis. Taigi, įterptos bioanglies abiejų normų teigiamas poveikis tęsèsi - OM kiekis išliko esmingai didesnis $(51,6-75,6 \%)$, nei bioanglies nenaudojant.

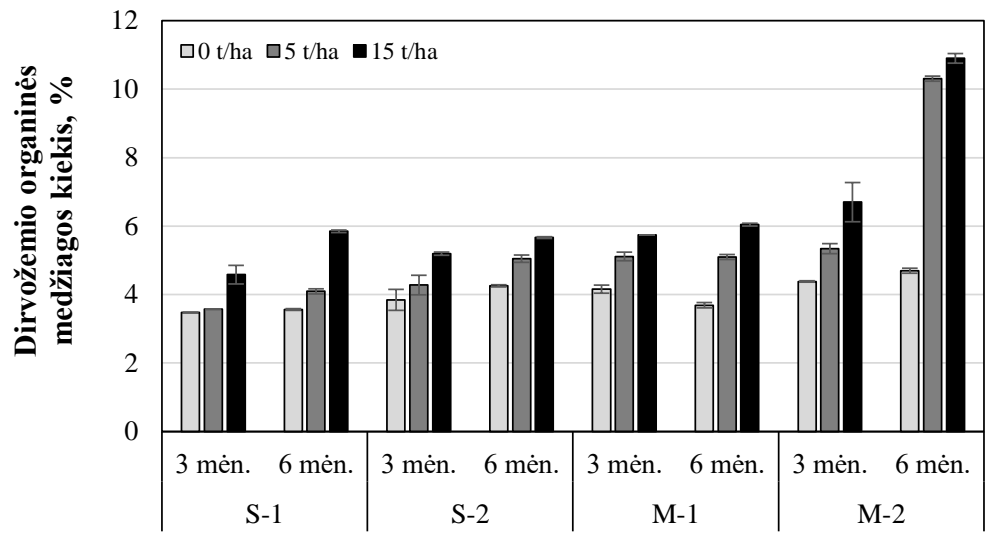

3.37 pav. Bioanglies įtaka organinès medžiagos kiekiui (\%) skirtingose žemės dirbimo ir tręšimo sistemose ( $\mathrm{S}$ - seklus neariminis žemè dirbimas, $\mathrm{M}$ - tiesioginè sèja, 1 - netręšta, 2 - tręšta) praejus 3 bei 6 menesiams, $n=2$

Fig. 3.37. Influence of biochar on soil's organic matter content (\%) in different tillagefertilization systems ( $\mathrm{S}$ - ploughless shallow tillage, $\mathrm{M}$ - direct drilling, 1 - unfertilized,

$2-$ fertilized) after 3 and 6 months, $n=2$

Nepriklausomai nuo tyrimo datos, bioanglies normos įtaka OM kiekiui buvo esminè visose žemès dirbimo ir tręšimo sistemose $(p<0,05)$ (3.14 lentelè). Kartu pažymètina, kad bioanglies naudojimas žemès nedirbant, bet taikant tiesioginę sėją (M), yra perspektyvesnis ir jos efektas yra didesnis dirvožemio OM didinti, nei S taikymas. S sistemoje (tiek netręšiant mineralinèmis trąšomis, tiek tręšiant) bioanglies 5 t/ha norma OM kiekị didino 8,8-15,2 \%, 15 t/ha norma - 34-48 \%, o M sistemoje - atitinkamai 30,2-72,4\% ir 50,2-93,9\%, palyginti su variantais be bioanglies. Verta pažymèti ir tai, kad, vidutiniais tyrimo duomenimis, $15 \mathrm{t} / \mathrm{ha}$ bioanglies normos naudojimas eksperimente sudare geriausias OM sąlygas tik tręšiant mineralinėmis trąšomis tiek $\mathrm{S}$, tiek $\mathrm{M}$ žemès dirbimo sistemose $(5,43 \%$ ir 8,79\%, atitinkamai). Svarbu ir tai, kad taikant M sistemą, ryškesnį efektą davė 15 t/ha bioanglies norma, ypač naudojant mineralines trąšas. 
3.14 lentelè. Dirvožemio organinès medžiagos kiekio dispersinès analizès rezultatai, $n=3$

Table 3.14. Results of analysis of variance of soil's organic matter, $n=3$

\begin{tabular}{|l|l|l|}
\hline \multicolumn{1}{|c|}{ Veiksniai ir jų sąveikos } & \multicolumn{1}{|c|}{ F-fakt } & \multicolumn{1}{|c|}{$\begin{array}{c}\text { Mažiausia patikimo } \\
\text { skirtumo riba } \mathrm{R}_{05}\end{array}$} \\
\hline Veiksnys A - tyrimo data & $1268,82^{* *}$ & 0,03 \\
\hline $\begin{array}{l}\text { Veiksnys B - žemės dirbimo ir tręšimo } \\
\text { sistema }\end{array}$ & $1767,05^{* *}$ & 0,052 \\
\hline Veiksnys C - bioanglies norma & $2030,74 * *$ & 0,043 \\
\hline $\mathrm{A} \times \mathrm{B}$ & $569,03 * *$ & 0,07 \\
\hline $\mathrm{A} \times \mathrm{C}$ & $270,39 * *$ & 0,064 \\
\hline $\mathrm{B} \times \mathrm{C}$ & $223,98 * *$ & 0,064 \\
\hline $\mathrm{A} \times \mathrm{B} \times \mathrm{C}$ & $120,28 * *$ & 0,104 \\
\hline$* * p<0,01$ & & \\
\hline
\end{tabular}

Galutinis rezultatų vertinimas parodè, kad taikant S dirbimą (tiek netręšiant, tiek tręšiant), 5 t/ha bioanglies norma OM kieki per pirmuosius 3 mèn. po jos iterpimo padidino $2,8-11,3 \%$, o 15 t/ha norma - 31,8-35,1\% palyginti su variantais be bioanglies. Bioanglies efektyvumas $\mathrm{M}$ sistemoje (tiek netręšiant, tiek tręšiant) buvo esmingai didesnis - 21,9-23\% ir 38-52,8\%, atitinkamai naudojant $5 \mathrm{t} / \mathrm{ha}$ ir $15 \mathrm{t} / \mathrm{ha}$ normas. Praejus 3 mèn. po bioanglies ịterpimo didžiausiu OM kiekiu pasižymèjo variantas, kuriame taikyta tiesioginè sèja + tręšimas +15 t/ha bioanglies norma $(6,69 \%)$.

Per kitus tris mėnesius (po 6 mèn.), taikant $\mathrm{S}$ dirbimą (tiek netręšiant, tiek tręšiant), 5 t/ha bioanglies norma OM kieki padidino dar 14,5-18 \%, o 15 t/ha norma - 8,9-27,5\%. Taikant $\mathrm{M}$ - atitinkamai iki 92,9 \% (5 t/ha atveju) ir 5,3$62,6 \%$ (15 t/ha atveju). Tręšimas tik M sistemoje padejjo išlaikyti didesni OM kiekį, naudojant $5 \mathrm{t} / \mathrm{ha}$ ir $15 \mathrm{t} / \mathrm{ha}$ bioanglies normas. Po 6 mèn. didžiausiu OM kiekiu pasižymèjo M-2 variantas, kuriame buvo ịterpta $15 \mathrm{t} / \mathrm{ha}$ bioanglies $(10,9 \%)$.

Po 6 mèn. dirvožemio $\mathrm{pH}$ buvo vidutiniškai 3,9 \% mažesnis nei po 3 mèn. Tręšimas lėmè mažesnị dirvožemio $\mathrm{pH}$ abiejose žemès dirbimo sistemose (S-2 $15,9 \%$ ir $\mathrm{M}-2-18,6 \%$ ). Vidutiniais viso eksperimento duomenimis ir nepriklausomai nuo žemès dirbimo ir tręšimo sistemos bei datos, 5 t/ha bioanglies norma $\mathrm{pH}$ padidino 3,6\%, o $15 \mathrm{t} / \mathrm{ha}$ esmingai, t. y. $10 \%$ (3.38 pav.). Nepriklausomai nuo bioanglies naudojimo per trijų mènesių laikotarpi $\mathrm{S}$ sistemoje pH sumažèjo 0,4-6,1\%, o M sistemoje 2,6-7,5\%. Naudojant mineralines NPK trąšas, abiejose žemès dirbimo sistemose $\mathrm{pH}$ pokyčiai per 3 mèn. laikotarpi buvo 
gerokai didesni, nei jų nenaudojant ir siekè 6,1-7,5\%. Nepriklausomai nuo žemès dirbimo ir tręšimo sistemos, praejus 3 mèn. nuo bioanglies įterpimo, $5 \mathrm{t} / \mathrm{ha}$ bioanglies norma $\mathrm{pH}$ padidino 2,5\%, o 15 t/ha norma esmingai, t. y. 7,6\%. Praejjus 6 mèn. po bioanglies įterpimo, $\mathrm{pH}$ padidèjo visuose variantuose $-1,8$ $6,1 \%$. Taigi, įterptos bioanglies abiejų normų teigiamas poveikis dirvožemio $\mathrm{pH}$ didèjimui tęsèsi - $\mathrm{pH}$ išliko esmingai didesnis $(4,8-12,5 \%)$, nei bioanglies nenaudojant.

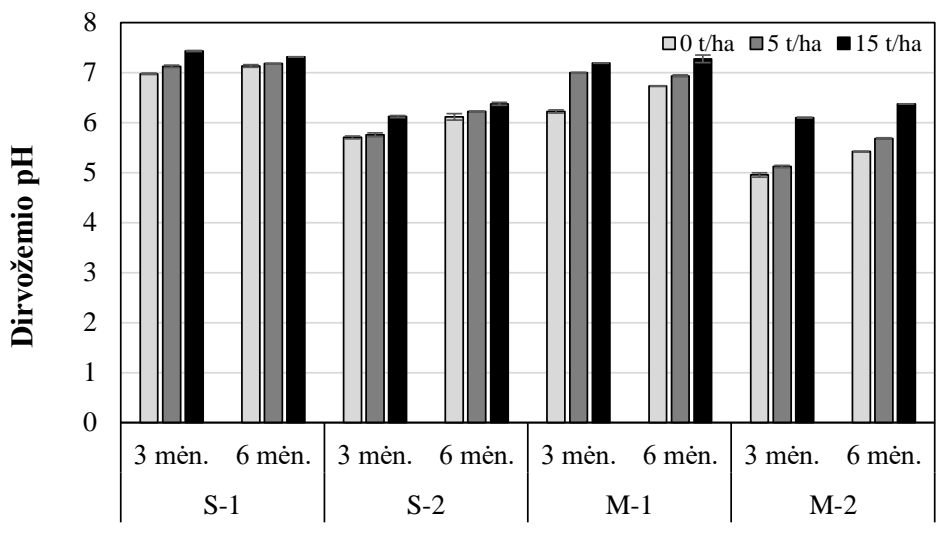

3.38 pav. Bioanglies įtaka dirvožemio $\mathrm{pH}$ skirtingose žemès dirbimo ir tręšimo sistemose ( $\mathrm{S}$ - seklus neariminis žemé dirbimas, $\mathrm{M}$ - tiesioginè sèja, 1 - netręšta, 2 - tręšta) praejjus 3 bei 6 mènesiams, $n=2$

Fig. 3.38. Influence of biochar on soil's $\mathrm{pH}$ in different tillage-fertilization systems ( $\mathrm{S}$ - ploughless shallow tillage, $\mathrm{M}$ - direct drilling, 1 - unfertilized, 2 - fertilized) after 3 and 6 months, $n=2$

Nepriklausomai nuo tyrimo datos, bioanglies ịtaka $\mathrm{pH}$ buvo esminè visose Žemès dirbimo ir tręšimo sistemose $(p<0,05)$ (3.15 lentelè). Bioanglies naudojimas taikant $\mathrm{M}$ buvo perspektyvesnis dirvožemio $\mathrm{pH}$ didinti. Jeigu $\mathrm{S}$ sistemoje (tiek netręšiant, tiek tręšiant) bioanglies $5 \mathrm{t} / \mathrm{ha}$ norma $\mathrm{pH}$ didino $1,4 \%$, o 15 t/ha norma - 4,5-5,7\%, tai M sistemoje - atitinkamai 4,2-7,6\% ir 11,7$20,2 \%$, palyginti su variantais be bioanglies. Vidutiniais tyrimo duomenimis, $15 \mathrm{t} / \mathrm{ha}$ bioanglies normos naudojimas lëmé aukštesni $\mathrm{pH}$ netręštame dirvožemyje tiek S, tiek M žemès dirbimo sistemose ( $\mathrm{pH} 7,37$ ir 7,23, atitinkamai).

Galutinis vertinimas parode, kad per pirmuosius 3 mèn. bioanglies ịterpimas padidino dirvožemio $\mathrm{pH}$, palyginti su dirvožemiu be bioanglies visose sistemose. Taikant $\mathrm{S}$ dirbimą (tiek netręšiant, tiek tręšiant) $5 \mathrm{t} / \mathrm{ha}$ bioanglies norma $\mathrm{pH}$ padidino atitinkamai $0,7-1,8 \%$, o $15 \mathrm{t} / \mathrm{ha}-2,5-4,3 \%$, palyginti su variantais be bioanglies. Tuo tarpu bioanglies efektyvumas M sistemoje (tiek netręšiant, tiek 
tręšiant) buvo esmingai didesnis, t. y. $3-4,9 \%$ ir $8,1-17,6 \%$, atitinkamai naudojant $5 \mathrm{t} / \mathrm{ha}$ ir $15 \mathrm{t} / \mathrm{ha}$ normas. Tiek tręštas, tiek netręštas $\mathrm{S}$ sistemos dirvožemis pasižymèjo didesnèmis $\mathrm{pH}$ vertėmis nei $\mathrm{M}$ dirvožemio. Praejjus 3 mèn. po bioanglies ịterpimo didžiausiu pH pasižymèjo variantas, kuriame taikytas seklus neariminis dirbimas + netręšta +15 t/ha bioanglies norma $(\mathrm{S}-1, \mathrm{pH} 7,31)$. Po 6 mèn. taikant $S$ dirbimą (tiek tręšiant, tiek netręšiant) 5 t/ha bioanglies norma $\mathrm{pH}$ sumažino $0,8-7,5 \%$, o 15 t/ha norma padidino $\mathrm{pH} 1,6 \%$ netręšiant, tačiau tręšiant sumažino $4 \%$. Taikant $\mathrm{M}-5 \mathrm{t} / \mathrm{ha}$ bioanglies norma padidino $\mathrm{pH} 0,9 \%$ netręšiant, o tręšiant sumažino $\mathrm{pH} 9,9 \%$, o naudojant 15 t/ha normą $\mathrm{pH}$ sumažèjo 4-4,3\%. Taigi laiko atžvilgiu bioanglies šarminimo poveikis dirvožemiui silpsta. Tręšimas NPK trąšomis tiek $\mathrm{S}$, tiek $\mathrm{M}$ sistemoje sumažino dirvožemio $\mathrm{pH}$ nepriklausomai nuo bioanglies ịterpimo. Po bioanglies įterpimo didžiausiu $\mathrm{pH}$ pasižymejjo S-1 ir 15 t/ha variantas ( $\mathrm{pH} 7,31$ ir 7,43, atitinkamai po 3 ir 6 mèn.).

3.15 lentelè. Dirvožemio $\mathrm{pH}$ dispersinès analizès rezultatai, $n=3$

Table 3.15. Results of analysis of variance of soil's $\mathrm{pH}, n=3$

\begin{tabular}{|l|l|l|}
\hline \multicolumn{1}{|c|}{ Veiksniai ir jų sąveikos } & \multicolumn{1}{|c|}{ F-fakt } & \multicolumn{1}{|c|}{$\begin{array}{c}\text { Mažiausia patikimo } \\
\text { skirtumo riba R05 }\end{array}$} \\
\hline Veiksnys A - tyrimo data & $3216,45^{* *}$ & 0,005 \\
\hline $\begin{array}{l}\text { Veiksnys B - žemės dirbimo ir } \\
\text { tręšimo sistema }\end{array}$ & $26515,51^{* *}$ & 0,008 \\
\hline Veiksnys C - bioanglies norma & $6367,2 * *$ & 0,006 \\
\hline $\mathrm{A} \times \mathrm{B}$ & $427,79 * *$ & 0,01 \\
\hline $\mathrm{A} \times \mathrm{C}$ & $280,09 * *$ & 0,01 \\
\hline $\mathrm{B} \times \mathrm{C}$ & $669,48^{* *}$ & 0,01 \\
\hline $\mathrm{A} \times \mathrm{B} \times \mathrm{C}$ & $98,33^{* *}$ & 0,016 \\
\hline
\end{tabular}

$* * p<0,01$

Po 6 mèn. elektrinis laidis (EL) buvo vidutiniškai 63,7 \% mažesnis nei po 3 mèn. Remiantis vidutiniais trečio ir šešto mènesių duomenimis, tręšimas lèmè didesnị EL. S sistemoje tręšiant (S-2) EL buvo vidutiniškai 116 \% didesnis, nei netręšiant (S-1). Taikant $\mathrm{M}$ sistemą tręšimo (M-2) efektyvumas minimam rodikliui buvo didesnis, t. y. EL buvo vidutiniškai 147 \% didesnis, nei netręšiant (M-1). Vidutiniais viso eksperimento duomenimis, 5 t/ha bioanglies ịterpimas EL padidino 8,2 \%, o 15 t/ha esmingai, t. y. 26,2 \% (3.39 pav.). 


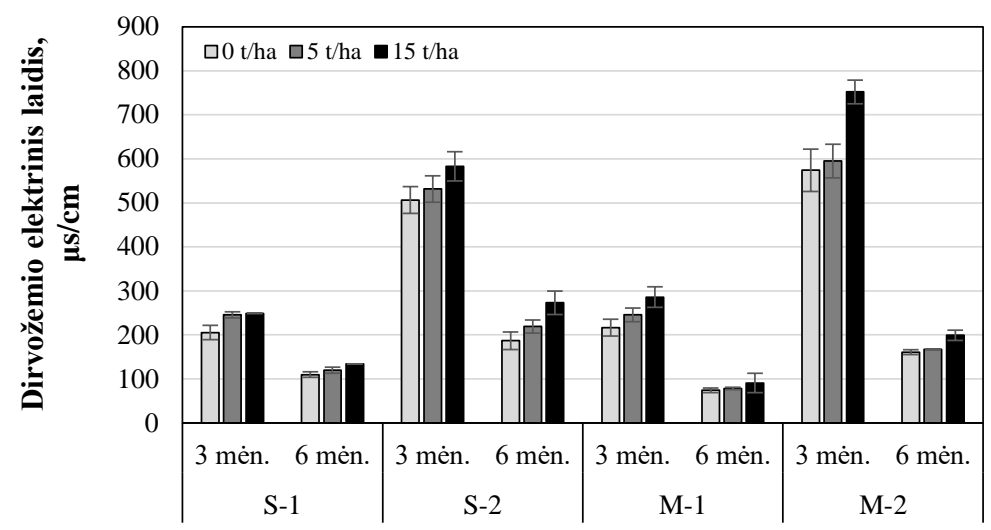

3.39 pav. Bioanglies ịtaka dirvožemio elektriniams laidžiui $(\mu \mathrm{s} / \mathrm{cm})$ skirtingose žemès dirbimo ir tręšimo sistemose ( $\mathrm{S}$ - seklus neariminis žemè dirbimas, $\mathrm{M}$ - tiesioginè sejja, 1 - netręšta, 2 - tręšta) praejjus 3 bei 6 mènesiams, $n=2$

Fig. 3.39. Influence of biochar on soil's electrical conductivity $(\mu \mathrm{s} / \mathrm{cm})$ in different tillage-fertilization systems ( $\mathrm{S}-$ ploughless shallow tillage, $\mathrm{M}$ - direct drilling, 1 - unfertilized, 2 - fertilized) after 3 and 6 months, $n=2$

Analizè atskleidè, kad nepriklausomai nuo bioanglies įterpimo, per 3 mèn. laikotarpi S sistemoje EL sumažejo 47,9-58,1 \%, M sistemoje - 67,5-72,6\%. Nepriklausomai nuo bioanglies naudojimo M taikymas sumažino dirvožemio EL, palyginti su S, vadinasi, augalų mitybos sąlygos M sistemoje buvo prastesnès nei $\mathrm{S}$ sistemoje. Tačiau, naudojant trąšas abiejose žemès dirbimo sistemose, EL teigiami pokyčiai per 3 mèn. laikotarpi buvo didesni, nei jų nenaudojant ir siekè 58,1-72,6\%. Nepriklausomai nuo žemès dirbimo ir tręšimo sistemos, praejjus 3 mèn. nuo bioanglies iterpimo, 5 t/ha bioanglies norma EL padidino 7,6\%, o 15 t/ha norma esmingai, t. y. 24,5\%. Praejjus 6 mèn. po bioanglies ịterpimo, EL sumažèjo visais variantais $62,7-64,6 \%$. Tokị dirvožemio EL sumažèjimą galèjo paskatinti aplinkos meteorologinės sąlygos (aukšta oro ir dirvožemio temperatūra liepos-rugpjūčio mẻnesiais) bei pakitusi dirvožemio fizikinè būklè (padidèjęs tankis ir kietumas). Visgi ịterptos bioanglies abiejų normų teigiamas poveikis tęsèsi - EL išliko esmingai didesnis (9,9-31,1\%), nei bioanglies nenaudojant. Nepriklausomai nuo tyrimo datos bioanglies įtaka dirvožemio EL buvo esminè visose žemès dirbimo ir tręšimo sistemose $(p<0,05)$ (3.16 lentelè). S sistemoje (tiek netręšiant, tiek tręšiant) bioanglies 5 t/ha norma EL didino 8,3-15,5\%, o 15 t/ha norma - 21,4-23,5\%, M sistemoje - atitinkamai 3,7-11,4\% ir 29,4$29,7 \%$, palyginti su variantais be bioanglies. 15 t/ha bioanglies normos 
naudojimas lèmé didžiausias EL vertes tik tręšiant trąšomis tiek $\mathrm{S}$, tiek $\mathrm{M}$ žemès dirbimo sistemose (428 ir $476 \mu \mathrm{s} / \mathrm{cm}$ atitinkamai).

3.16 lentelè. Dirvožemio elektrinio laidžio dispersinès analizès rezultatai, $n=3$

Table 3.16. Results of analysis of variance of soil's electrical conductivity, $n=3$

\begin{tabular}{|l|l|l|}
\hline \multicolumn{1}{|c|}{ Veiksniai ir jų sąveikos } & \multicolumn{1}{|c|}{ F-fakt } & \multicolumn{1}{c|}{$\begin{array}{c}\text { Mažiausia patikimo skirtumo } \\
\text { riba R05 }\end{array}$} \\
\hline Veiksnys A - tyrimo data & $10637,27 * *$ & 2,58 \\
\hline $\begin{array}{l}\text { Veiksnys B - žemès } \\
\text { dirbimo ir tręšimo sistema }\end{array}$ & $2569,38^{* *}$ & 4,47 \\
\hline $\begin{array}{l}\text { Veiksnys C - bioanglies } \\
\text { norma }\end{array}$ & $235,03^{* *}$ & 3,65 \\
\hline $\mathrm{A} \times \mathrm{B}$ & $950,54^{* *}$ & 5,97 \\
\hline $\mathrm{A} \times \mathrm{C}$ & $33,98^{* *}$ & 5,48 \\
\hline $\mathrm{B} \times \mathrm{C}$ & $22,03^{* *}$ & 5,48 \\
\hline $\mathrm{A} \times \mathrm{B} \times \mathrm{C}$ & $17,52^{* *}$ & 11,9 \\
\hline
\end{tabular}

$* * p<0,01$

Apibendrinant galima teigti, kad, taikant $\mathrm{S}$ dirbimą (tiek tręšiant, tiek netręšiant), 5 t/ha bioanglies norma dirvožemio EL per pirmuosius 3 mèn. po jos iterpimo padidino 4,9-19\%, o 15 t/ha - 15,1-21,2 \%, palyginti su variantais be bioanglies. $\mathrm{M}$ sistemoje (tiek tręšiant, tiek netręšiant) bioanglies efektyvumas buvo esmingai didesnis tik naudojant 15 t/ha normą - atitinkamai 31-32,1\%. Tręšimas abiejose dirbimo sistemose padejjo išlaikyti didesnị EL nepriklausomai nuo bioanglies įterpimo. Tai rodo, kad tręšimas dirvožemio porose esmingai padidino druskų koncentraciją. Praèjus 3 mèn. po bioanglies įterpimo didžiausiu EL pasižymejjo variantas, kuriame taikyta tiesioginè sèja + tręšimas +15 t/ha bioanglies norma $(752 \mu \mathrm{s} / \mathrm{cm})$.

Po 6 mèn., taikant $S$ dirbimą (tiek tręšiant, tiek netręšiant) ir naudojant 5 t/ha bioanglies normą, EL sumažėjo 51-58,8 \%, o naudojant 15 t/ha normą EL sumažejo mažiau ir siekè 46,2-53,2\%. Taikant $M$ sistemą bioanglies $5 \mathrm{t} / \mathrm{ha}$ ir 15 t/ha normų įtaka buvo labai panaši - EL sumažejjo atitinkamai $68,1-71,9 \%$ ir 68,3-73,5\%. Tręšimas abiejose sistemose padejo išlaikyti didesni EL nepriklausomai nuo bioanglies ịterpimo. Didžiausiu EL pasižymėjo S-2 variantas, kuriame buvo ịterpta $15 \mathrm{t} / \mathrm{ha}$ bioanglies $(273 \mu \mathrm{s} / \mathrm{cm})$. Taigi, rezultatai demonstruoja, kad žemės dirbimas ir tręšimas tiesiogiai veikdami dirvožemio fizikinę būklę, nulemia ir jo elektrinį laidị bei augalų mitybos sąlygas. Ir 
dirvožemio tipas, ir žemėnauda turi reikšmingą itaką bendram makroporingumui, jo paviršiaus plotui ir porų pasiskirstymui dirvožemyje. Atitinkamai makroporų, taip pat ir mezoporų skaičius bei jų pasiskirstymas yra svarbus veiksnys, lemiantis vandens kiekị tose porose ir jų elektrinị laidị (Kochiieru et al., 2018, 2020).

Remiantis FTIR analizès rezultatais, eksperimento pradžioje (po 3 mèn.) tiek $\mathrm{M}$, tiek S sistemų dirvožemio FTIR spektrai buvo panašūs ir pasižymėjo šiomis funkcinėmis grupėmis: alkoholinėmis $-\mathrm{OH}\left(3626 \mathrm{~cm}^{-1}\right)$, alkoksinėmis $\mathrm{C}-\mathrm{O}$ $\left(1023-1084 \mathrm{~cm}^{-1}\right)$, aromatinèmis $\mathrm{C}-\mathrm{H}\left(777-873 \mathrm{~cm}^{-1}\right)$ ir $\mathrm{C}=\mathrm{C}\left(1643 \mathrm{~cm}^{-1}\right)$ (3.42 pav.). Lyginant tręštus dirvožemius, paveiktus skirtingo kiekio bioanglimi, abiejose dirvožemio sistemose matyti, kad didžiausiu funkcinių grupių kiekiu pasižymejjo $5 \mathrm{t} / \mathrm{ha}$ bioanglies norma (dèl didesnio infraraudonujų spindulių absorbcijos intensyvumo), o mažiausiu - $15 \mathrm{t}$ /ha norma. Netręštame dirvožemyje (S-1) absorbcijos pikai ties $1023-1084 \mathrm{~cm}^{-1}$ ir $466-522 \mathrm{~cm}^{-1}$ bangos skaičiais buvo stipresni, esant $5 \mathrm{t} / \mathrm{ha}$ bioanglies iterpimo kiekiui, o $\mathrm{M}$ sistemoje - visi absorbcijos pikai buvo stipresni prie 15 t/ha bioanglies normos. Galima teigti, kad dirvožemio tręšimas mineralinèmis trąšomis lèmė stabilesnę jo struktūrą skirtingose sistemose nepriklausomai nuo bioanglies ịterpimo, o netręšto dirvožemio cheminè struktūra stipriai kito priklausomai nuo bioanglies normos.
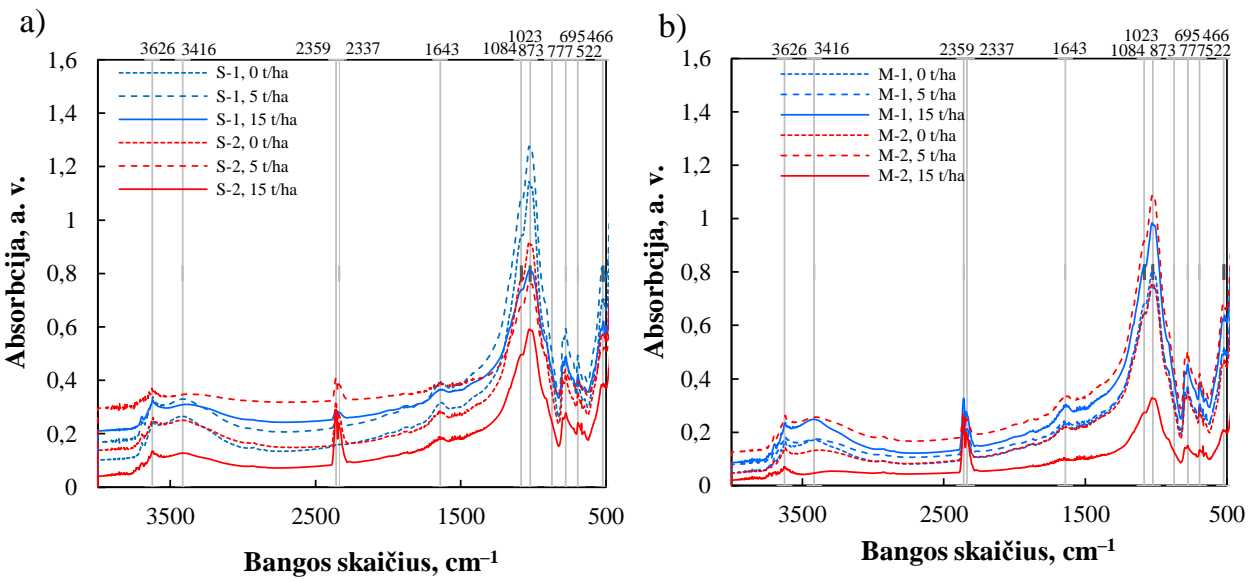

3.40 pav. Bioanglies įtaka dirvožemio paviršiaus funkcinėms grupėms skirtingose žemės dirbimo ir tręšimo sistemose praejjus 3 mèn.: a) $\mathrm{S}$ - seklus neariminis žemè dirbimas;

b) M - tiesioginè sèja; 1 - netręšta; 2 - tręšta, $n=2$

Fig. 3.40. Influence of biochar on functional groups of soil surface in different tillage-fertilization systems after 3 months: a) $\mathrm{S}$ - ploughless shallow tillage,

b) M - direct drilling, 1 - unfertilized, 2 - fertilized, $n=2$ 
-OH grupé dirvožemyje siejama su kaolinito molio mineralais $(3694,3620$, $\left.3526 \mathrm{~cm}^{-1}\right)$, Si-O grupe - su silikatais $\left(1031 \mathrm{~cm}^{-1}\right)$, o Al-Al-OH - aliuminio junginiais $\left(913 \mathrm{~cm}^{-1}\right)$ (Qayyum et al., 2014). Panašiai šiame tyrime nustatyti pikai ties $3626,3416,1023$ ir $873 \mathrm{~cm}^{-1}$ bangos skaičiais, o tai rodo $\mathrm{O}, \mathrm{H}, \mathrm{Al}$ ir $\mathrm{Si}$ junginių buvimą dirvožemio struktūroje. Pikas ties $471 \mathrm{~cm}^{-1}$ bangos skaičiumi paprastai siejamas su Si kiekiu (Wang et al., 2018). Iš FTIR spektrų matyti, kad visos dirvožemio tiriamosios grupès nepasižymėjo hidrofobinèmis $\mathrm{C}-\mathrm{H}$ metilo ir metileno funkcinėmis grupèmis (pikų neatsiradimas ties 2920 ir $2860 \mathrm{~cm}^{-1}$ ). C-O funkcinès grupès (pikai ties $1600-1740 \mathrm{~cm}^{-1}$ ), kurios siejamos su hidrofiliškumu, buvo nustatytos visose dirvožemio grupèse (pikai ties $1643 \mathrm{~cm}^{-1}$ ). Dirvožemių hidrofiliškumas didejja augant polinių grupių (kaip kad $-\mathrm{OH},-\mathrm{COOH}$ ir $-\mathrm{NH}_{2}$ ) tankiui, bet mažèja augant nepoliniu grupių $\left(-\mathrm{CH}_{3}\right.$ ir $\left.=\mathrm{CH}_{2}\right)$ tankiui (Zemfira, Milanovskiy, 2015).

Po 6 mèn. dirvožemio VSG buvo 19,7\% didesnè nei po 3 mèn. Vidutiniais trečio ir šešto mènesių duomenimis, tręšimas lèmé didesnę VSG. S sistemoje tręšiant (S-2) VSG buvo vidutiniškai 3,8 \% didesnè nei netręšiant (S-1), o taikant $\mathrm{M}$ tręšimo sistemą (M-2) poveikis minimam rodikliui buvo didesnis, t. $y$. VSG buvo 7,0 \% didesnè nei netręšiant (M-1). Nepriklausomai nuo žemès dirbimo ir tręšimo sistemos bei datos, 5 t/ha bioanglies įterpimas VSG padidino $4,9 \%$, o 15 t/ha esmingai stipriau, t. y. $8,9 \%$ (3.41 pav.).

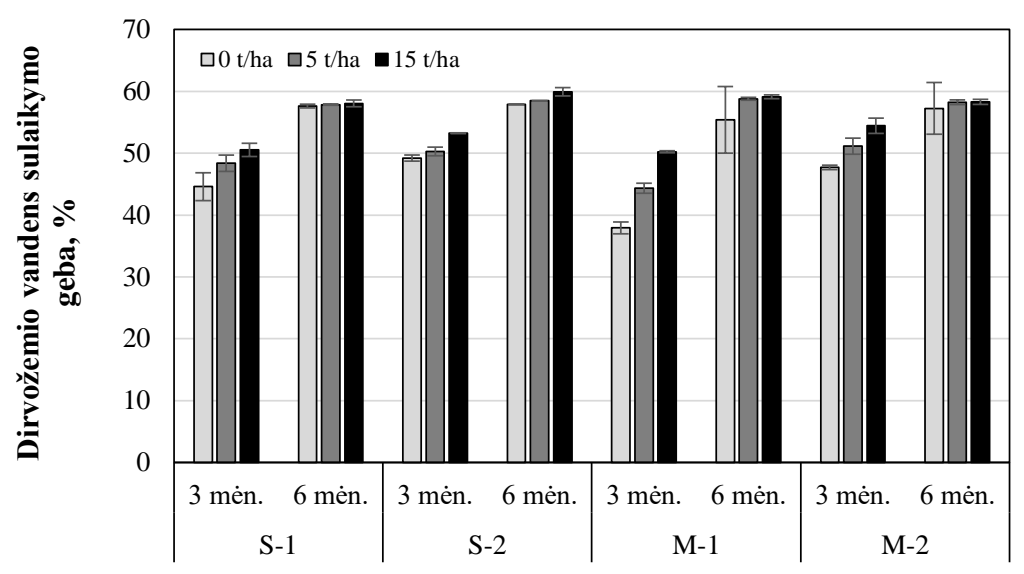

3.41 pav. Bioanglies įtaka dirvožemio vandens laikomajai gebai (\%) skirtingose dirbimo ir tręšimo sistemose praejjus 3 ir 6 mènesiams: a) $\mathrm{S}$ - seklus neariminis žemė dirbimas;

b) M - tiesioginè sejja; 1 - netręšta; 2 - tręšta, $n=2$

Fig. 3.41. Influence of biochar on soil's water holding capacity (\%) different tillagefertilization systems after 3 and 6 months: a) $\mathrm{S}$ - ploughless shallow tillage;

b) M - direct drilling; 1 - unfertilized; 2 - fertilized, $n=2$ 
Nepriklausomai nuo bioanglies naudojimo, per 3 mèn. laikotarpi S sistemoje VSG padidèjo 15,4-20,9\%, o M sistemoje - 13,4-30,8 \%. Taigi, M sistemos taikymas buvo efektyvesnis nei S. Tačiau naudojant NPK trąšas, abiejose žemès dirbimo sistemose VSG pokyčiai per 3 mèn. laikotarpi buvo kur kas mažesni, nei jų nenaudojant, ir siekè 13,4-15,4\%. Praejjus 3 mèn. nuo bioanglies įterpimo, $5 \mathrm{t} /$ ha bioanglies norma VSG padidino $8,2 \%$, o 15 t/ha norma esmingai, t. y. $16,2 \%$. Praejus 6 mèn., VSG padidejjo visais variantais 12,9-27,2 \%. Tam įtakos turejjo ir meteorologinès sąlygos, ir dirvožemio fizikinès savybès. Bioanglies abiejų normų teigiamas poveikis tęsèsi - VSG išliko esmingai didesnè $(2,3-$ $3,2 \%$ ) nei be bioanglies. Nepriklausomai nuo tyrimo datos, bioanglies įtaka VSG buvo esminè visose žemès dirbimo ir tręšimo sistemose $(p<0,05)$ (3.17 lentelè). Kartu pažymėtina, kad bioanglies naudojimas taikant $M$ yra perspektyvesnis ir jos efektas yra didesnis. Jeigu S sistemoje (tiek netręšiant, tiek tręšiant) bioanglies $5 \mathrm{t} /$ ha norma VSG didino $1,5-3,9 \%$, o 15 t/ha norma - 5,7-6,2\%, tai $\mathrm{M}$ sistemoje - atitinkamai $4,2-10,5 \%$ ir 7,4-17,2\% palyginti su variantais be bioanglies. $15 \mathrm{t} / \mathrm{ha}$ bioanglies normos naudojimas sudarè geriausias VSG sąlygas tik tręšiant mineralinemis trąšomis tiek $\mathrm{S}$, tiek $\mathrm{M}$ žemès dirbimo sistemose (56,6 \% ir 56,4\%, atitinkamai).

3.17 lentelė. Dirvožemio vandens laikomajai gebos dispersinès analizės rezultatai, $n=3$

Table 3.17. Results of analysis of variance of soil's water holding capacity, $n=3$

\begin{tabular}{|l|l|l|}
\hline \multicolumn{1}{|c|}{ Veiksniai ir jų sąveikos } & \multicolumn{1}{|c|}{ F-fakt } & \multicolumn{1}{|c|}{$\begin{array}{c}\text { Mažiausia patikimo } \\
\text { skirtumo riba } \mathrm{R}_{05}\end{array}$} \\
\hline Veiksnys A - tyrimo data & $1320,84^{* *}$ & 0,265 \\
\hline $\begin{array}{l}\text { Veiksnys B }- \text { žemės dirbimo ir tręšimo } \\
\text { sistema }\end{array}$ & $45,48^{* *}$ & 0,459 \\
\hline Veiksnys C - bioanglies norma & $98,96^{* *}$ & 0,375 \\
\hline $\mathrm{A} \times \mathrm{B}$ & $32,27 * *$ & 0,612 \\
\hline $\mathrm{A} \times \mathrm{C}$ & $35,69 * *$ & 0,563 \\
\hline $\mathrm{B} \times \mathrm{C}$ & $7,35^{* *}$ & 0,563 \\
\hline $\mathrm{A} \times \mathrm{B} \times \mathrm{C}$ & $2,49^{*}$ & 0,919 \\
\hline
\end{tabular}

$* * p<0,01 ; * p<0,05$

Galutinis vertinimas parode, kad taikant $\mathrm{S}$ dirbimą (tiek tręšiant, tiek netręšiant) 5 t/ha bioanglies norma per pirmuosius 3 mèn. VSG padidino 2,2$8,5 \%$, o 15 t/ha norma $-8,2-13,3 \%$, palyginus su variantais, kuriuose bioanglis nebuvo naudota. Bioanglies efektyvumas $M$ sistemoje (tiek tręšiant, tiek 
netręšiant) buvo esmingai didesnis - naudojant $5 \mathrm{t} / \mathrm{ha}$ ir $15 \mathrm{t} / \mathrm{ha}$ normas atitinkamai 7,2-16,9\% ir 14,1-32,5\%. Tręšimas abiejose dirbimo sistemose padejo išlaikyti didesnę VSG nepriklausomai nuo bioanglies įterpimo. Praejjus 3 mèn. po jos įterpimo geriausia VSG pasižymèjo variantas, kuriame taikyta tiesioginè sèja + tręšimas +15 t/ha bioanglies norma $(54,4 \%)$.

Po 6 mèn. taikant $S$ dirbimą (tiek tręšiant, tiek netręšiant) 5 t/ha bioanglies norma VSG padidino dar 16,3-19,6 \%, o 15 t/ha norma - 12,6-14,9\%. Taikant $\mathrm{M}$ - atitinkamai 13,9-32,6\% ir 7,1-17,7\%. Tręšimas tik S sistemoje padejo išlaikyti didesnę VSG, naudojant tiek $5 \mathrm{t} / \mathrm{ha}$, tiek ir $15 \mathrm{t} / \mathrm{ha}$ bioanglies normas. Praejjus 6 mèn. geriausia VSG pasižymejjo S-2 ir M-1 variantai, kuriuose buvo iterpta 15 t/ha bioanglies (atitinkamai 59,9\% ir 59,1\%).

Po 6 mèn. dirvožemio drègmès kiekis (DK) buvo vidutiniškai 357 \% didesnis nei po 3 mèn. Tręšimas lèmė didesnị DK. S dirbimo sistemoje, tręšiant (S-2) DK buvo $50,5 \%$ didesnis, nei netręšiant $(\mathrm{S}-1)$. Taikant $\mathrm{M}$ sistemą, tręšimo poveikis minimam rodikliui buvo mažesnis ir sieke $34,8 \% .5$ t/ha bioanglies įterpimas DK padidino 33,8 \%, o 15 t/ha - esmingai stipriau, t. y. 65,1 \% (3.44 pav.).

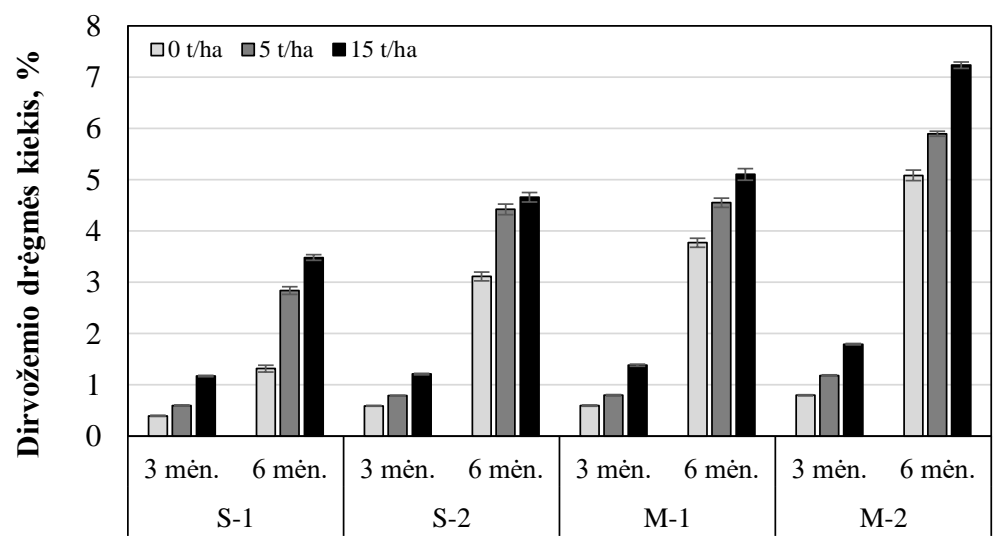

3.42 pav. Bioanglies įtaka dirvožemio drègmès kiekiui (\%) skirtingose dirbimo ir tręšimo sistemose praejjus 3 ir 6 mènesiams: a) $\mathrm{S}$ - seklus neariminis žemé dirbimas;

b) M - tiesioginè sèja; 1 - netręšta; 2 - tręšta, $n=2$

Fig. 3.42. Influence of biochar on soil water content $(\%)$ different tillage-fertilization systems after 3 and 6 months: a) $\mathrm{S}$ - ploughless shallow tillage; b) $\mathrm{M}$ - direct drilling; 1 - unfertilized; 2 - fertilized, $n=2$

Per 3 mèn. laikotarpi S sistemoje DK padidèjo 255-375 \%, o M sistemoje 383-385 \%. Taigi, M taikymas buvo efektyvesnis DK didejjimui nei S dirbimas. Naudojant NPK trąšas, S ir M sistemose DK pokyčiai per 3 mèn. laikotarpi buvo didesni, nei netręšiant (atitinkamai $375 \%$ ir $385 \%$ ). Nepriklausomai nuo žemès 
dirbimo ir tręšimo sistemos, 5 t/ha bioanglies norma DK padidino $41,1 \%$, o 15 t/ha norma tris kartus daugiau, t. y. $132 \%$. Praejjus 6 mèn., DK padidejo visais variantais 269-461\%. Tam įtakos galèjo turèti meteorologinès sąlygos, visų pirma krituliai (balandžio-birželio mèn. kritulių kiekis buvo mažesnis $(10,4 \mathrm{~mm})$ nei liepos-rugpjūčio mèn. $(28,8 \mathrm{~mm}))$. Bioanglies abiejų normų teigiamas poveikis tęsèsi - DK išliko esmingai didesnis $(32,6-53,1 \%)$ nei be bioanglies. Nepriklausomai nuo tyrimo datos, bioanglies įtaka dirvožemio DK buvo esminè visose žemès dirbimo ir tręšimo sistemose $(p<0,05)$ (3.18 lentelè). Kartu reikia pabrěžti, kad bioanglies naudojimas taikant $\mathrm{S}$ yra perspektyvesnis ir jos efektas yra didesnis. S sistemoje (tiek netręšiant mineralinèmis trąšomis, tiek tręšiant) bioanglies $5 \mathrm{t} / \mathrm{ha}$ norma DK didino 40,2-97,9\%, o $15 \mathrm{t} / \mathrm{ha}$ norma - 57,6-166\%, o M sistemoje - atitinkamai tik 19,5-22,2\% ir 48,3-52,3\%, palyginti su variantais be bioanglies. $15 \mathrm{t} / \mathrm{ha}$ bioanglies normos naudojimas lèmé geriausias DK sąlygas tik tręšiant mineralinèmis trąšomis tiek $\mathrm{S}$, tiek $\mathrm{M}$ žemès dirbimo sistemose (atitinkamai 2,97\% ir 4,54\%).

3.18 lentelè. Dirvožemio drègmès kiekio dispersinès analizès rezultatai, $n=3$

Table. 3.18. Results of analysis of variance of soil water content, $n=3$

\begin{tabular}{|l|l|l|}
\hline \multicolumn{1}{|c|}{ Veiksniai ir jų sąveikos } & \multicolumn{1}{|c|}{ F-fakt } & \multicolumn{1}{c|}{$\begin{array}{c}\text { Mažiausia } \\
\text { patikimo skirtumo } \\
\text { riba } \mathrm{R}_{05}\end{array}$} \\
\hline Veiksnys A - tyrimo data & $1320,84^{* *}$ & 0,265 \\
\hline Veiksnys B - žemės dirbimo ir tręšimo sistema & $45,48^{* *}$ & 0,459 \\
\hline Veiksnys C - bioanglies norma & $98,96^{* *}$ & 0,375 \\
\hline $\mathrm{A} \times \mathrm{B}$ & $32,27^{* *}$ & 0,612 \\
\hline $\mathrm{A} \times \mathrm{C}$ & $35,69^{* *}$ & 0,563 \\
\hline $\mathrm{B} \times \mathrm{C}$ & $7,35^{* *}$ & 0,563 \\
\hline $\mathrm{A} \times \mathrm{B} \times \mathrm{C}$ & $2,49^{*}$ & 0,919 \\
\hline
\end{tabular}

$* * p<0,01 ; * p<0,05$

Galutinis vertinimas parodè, kad taikant $\mathrm{S}$ dirbimą (tiek tręšiant, tiek netręšiant), $5 \mathrm{t} / \mathrm{ha}$ bioanglies norma DK per pirmuosius 3 mèn. po jos įterpimo padidino 33-50\%, o $15 \mathrm{t} / \mathrm{ha}$ norma - 104-192\%, palyginus su variantais be bioanglies. M sistemoje (tiek netręšiant, tiek tręšiant) DK buvo esmingai didesnis naudojant 15 t/ha normą (atitinkamai $132 \%$ ir $124 \%$ ). Praejjus 3 mèn. geriausiu DK pasižymėjo M-2 variantas, kuriame buvo įterpta $15 \mathrm{t} / \mathrm{ha}$ bioanglies (DK = 1,8 \%). Po 6 mèn., taikant $S$ dirbimą (tiek netręšiant, tiek tręšiant) 5 t/ha 
bioanglies norma DK padidino dar 377-466 \%, o 15 t/ha norma - 198-287\%. Taikant M, atitinkamai 397-472\% ir 271-304\%. Praejus 6 mèn. geriausiu DK pasižymèjo M-2 variantas, kuriame buvo įterpta $15 \mathrm{t} / \mathrm{ha}$ bioanglies $(7,28 \% \mathrm{DK})$.

Visuose variantuose tirtas dirvožemis pasižymėjo dideliu drèkumu (VLSL $\leq$ $1 \mathrm{~s})$ per visą 6 mẻnesių tyrimų laikotarpį. Dirvožemiai, pasižymintys momentiniu drèkumu (kai VLSL $\leq 1 \mathrm{~s}$ ), laikomi hidrofiliškais. Tokị šių tyrimų rezultatą galima aiškinti hidrofilinèmis funkcinėmis grupèmis, kurios siejasi su natūraliu dirvožemio drèkumu dèl jos galimai drèkios minerologinès sudèties. Remiantis kitu tyrimu (Ojeda et al., 2015), kai buvo vertintas bioanglies poveikis kai kurioms dirvožemio savybėms, nustatytas bioanglies drèkumo padidejimas remiantis vandens lašelio skverbimosi laiko testu po jos įterpimo ị dirvožemị po 1 metų. Vidutinès kontakto laipsnio vertės sumažèjo $69,5 \%$. Šis rezultatas parodè, kad pradinis bioanglies hidrofobiškumas (kontakto laipsnis daugiau nei $90^{\circ}$ ) buvo prarastas po 1 metų.

Buvo ịvertinta dirvožemio hidrofilinès funkcinès grupès $(\mathrm{C}-\mathrm{O})$ absorbcijos intensyvumo koreliacija su dirvožemio organinès medžiagos kiekiu (\%), $\mathrm{pH}$, elektriniu laidžiu $(\mu \mathrm{s} / \mathrm{cm})$, vandens laikomaja geba (\%) bei drègmès kiekiu (\%). Gauti koreliacijos rezultatai pateikiami 3.19 lentelèje.

3.19 lentelè. Koreliacija tarp dirvožemio hidrofilinès grupès $(\mathrm{C}-\mathrm{O})$ intensyvumo bei kitų fizikinių ir cheminių savybių, išreikšta Pirsono koreliacijos koeficientais $r, n=12$

Table 3.19. Correlation between soil hydrophilic group $(\mathrm{C}-\mathrm{O})$ intensity and other physico-chemical properties expressed by Pearson correlation coefficients $r, n=12$

\begin{tabular}{|l|l|l|l|l|l|}
\hline \multicolumn{1}{|c|}{ Parametras } & $\begin{array}{c}\text { Organinès } \\
\text { medžiagos } \\
\text { kiekis, \% }\end{array}$ & $\begin{array}{c}\text { Elektrinis } \\
\text { laidis, } \mu \mathrm{s} / \mathrm{cm}\end{array}$ & $\mathrm{pH}$ & $\begin{array}{c}\text { Vandens } \\
\text { laikomoji } \\
\text { geba, \% }\end{array}$ & $\begin{array}{l}\text { Drègmès } \\
\text { kiekis, \% }\end{array}$ \\
\hline $\begin{array}{l}\mathrm{C}-\mathrm{O} \text { grupés } \\
\text { intensyvumas, a.u. }\end{array}$ & $-0,59$ & $-0,47$ & 0,25 & $-0,081$ & $-0,46$ \\
\hline
\end{tabular}

Reikšminga stipriausia neigiama koreliacija pasižymejjo dirvožemio hidrofilinių grupių intensyvumo ir OM kiekio sąveika $(r=-0,59)$. Esant mažesniam dirvožemio OM kiekiui, hidrofilinių funkcinių grupių buvo daugiau (dèl ịvertintų didesnių absorbcijos intensyvumų FTIR spektruose), o didejjant OM kiekiui šių grupių mažèjo (3.43 pav.).

Kiti tyrimai panašiai nurodè, kad dirvožemio drèkumas ir organinè medžiaga reikšmingai koreliavo su dirvožemio hidrofiliniais komponentais. Voelkner et al. (2015) tyrime akumuliuoti hidrofobinès $\mathrm{C}-\mathrm{H}$ grupès absorbcijos pikai buvo lyginami su hidrofilinès $\mathrm{C}-\mathrm{O}$ grupès pikais siekiant įvertinti potencialų dirvožemio drèkumą. Nustatyta, kad hidrofobinių ir hidrofilinių grupių santykis geriausiai koreliavo su dirvožemio drèkumu. 


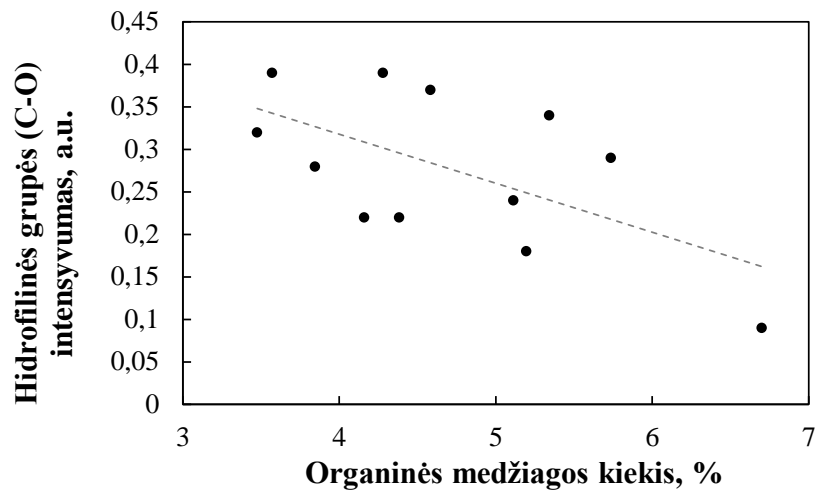

3.43 pav. Dirvožemio hidrofilinès grupès ( $\mathrm{C}-\mathrm{O}$, a.u.), susietos su dirvožemio organinès medžiagos kiekiu (\%)

Fig. 3.43. Soil hydrophilic groups $(\mathrm{C}-\mathrm{O}$, a.u.) related to the soil organic matter content $(\%)$

Taigi, tirtas smėlingasis lengvojo priemolio rudžemis nepriklausomai nuo tyrimo datos, dirvožemio dirbimo ir tręšimo sistemos bei bioanglies normos, buvo hidrofilinis (VLSL $\leq 1 \mathrm{~s}$ ). Dirvožemio hidrofiliškumo tendencija priklausé nuo molekulinès spektrometrijos rezultatų, kurie parodè, kad jo struktūroje buvo kaolinitų (pikai ties 3626 ir $3416 \mathrm{~cm}^{-1}$ ) ir aliumosilikatinių mineralų. Kaolinitas iš pradžiu yra hidrofiliškas, o-OH grupe yra pagrindinis veiksnys, lemiantis jo didelę trauką vandeniui. Silikatams būdingas hidrofiliškumas, kurio pagrindinis vienetas ( $\mathrm{Si}-\mathrm{O}$ grupè) buvo rastas tirtuose dirvožemio FTIR spektruose (pikai ties 1023 ir $466 \mathrm{~cm}^{-1}$ ). Nors pušies medienos bioanglis buvo hidrofobinè $(\mathrm{VLSL}=1810 \mathrm{~s})$, žemès ūkio dirvožemis išliko hidrofiliškas, neatsižvelgiant ị bioanglies normą. Tai gali būti siejama su natūraliu abiotinių veiksnių (kritulių ir vejo) poveikiu didinti bioanglies hidrofiliškumą. Didesnị bioanglies hidrofobiškumą galima sieti su jos didesniu pelenų kiekiu (16,6 \%), mažesniu deguonies kiekiu (3,39\%) ir SPP $\left(2,77 \mathrm{~m}^{2} / \mathrm{g}\right)$, lyginant su kitais žematemperatūriais bioanglies tipais. Žaliavų, turinčių didesnị pelenų kiekį, paviršiaus plotas paprastai yra mažesnis, palyginti su žaliavomis, kurių pelenų kiekis yra mažesnis, nes pelenai blokuoja porų erdvę. Dirvožemio hidrofilinių funkcinių grupių intensyvumas $(\mathrm{C}-\mathrm{O})$ neigiamai koreliavo su $\mathrm{OM}$ kiekiu $(r=-0,59)$. Tai rodo, kad mažesnị dirvožemio OM kiekị galima apibūdinti didesniu hidrofilinių funkcinių grupių kiekiu, todèl dirvožemiai, kuriuose yra daugiau organinių medžiagų, pasižymės mažesniu hidrofiliškumu. Tiesioginė sėja pagerino fizines ir chemines dirvožemio savybes: VSG, drègmès kiekį, $\mathrm{pH}$ ir $\mathrm{OM}$ kiekị. Tiesioginè sejja, tręšimas mineralinèmis azoto, fosforo, kalio trąšomis ir 15 t/ha bioanglies norma padidino VSG 32,5\%, o $\mathrm{pH}-17,6 \%$ praejjus 3 mèn. 


\subsection{Kapiliarinio kilimo greičio bioanglyje skaitinio modeliavimo rezultatai}

Buvo atliktas $600 \mathrm{~min}$. vandens kapiliarinio kilimo greičio $(\mathrm{m} / \mathrm{s})$ modeliavimas, remiantis multifazès tekejjimo poringaja medžiaga modeliu naudojant stambios, vidutinès bei smulkios frakcijos pušies medienos bioangli (3.44 pav.). Nustatyta, kad praejjus $36000 \mathrm{~s}$, stambi bioanglis buvo prisotinta vandeniu iki $3,1 \mathrm{~cm}$ aukščio (3.44a pav.), vidutinè - iki $3,79 \mathrm{~cm}$ (3.44b pav.), o smulki - iki $9,83 \mathrm{~cm}$ (3.44c pav.). Mažèjant frakcijos dydžiui iki $<300 \mu \mathrm{m}$, kapiliarinis kilimo greitis didèjo. Matyti, kad smulki bioanglis pasižymèjo didžiausiu kapiliariniu kilimu ir tai galèjo lemti mažiausias porų spindulys $\left(6,38 \cdot 10^{-6} \mathrm{~m}\right)$ ir kontakto laipsnis $\left(79^{\circ}\right)$, didžiausias poringumas $(82 \%)$ ir laidumas $\left(4,55 \cdot 10^{-16} \mathrm{~m}^{2}\right)$, lyginant su kitomis frakcijomis.

a)

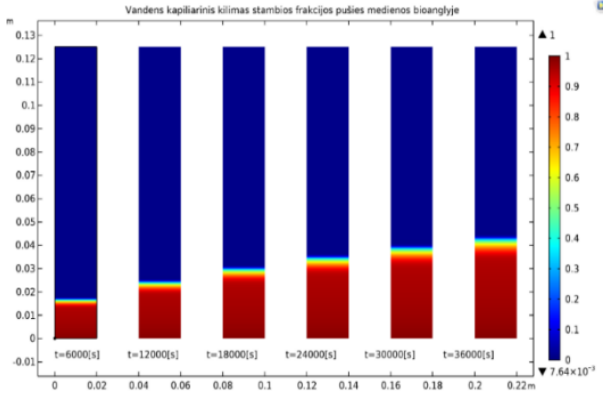

c)

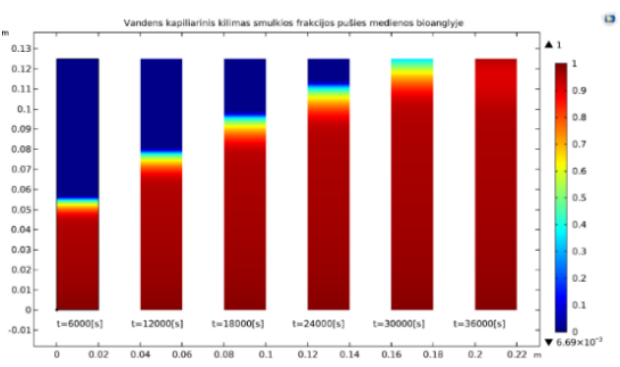

b)

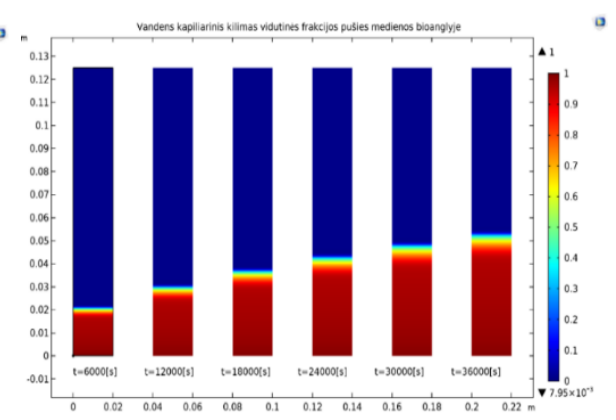

3.44 pav. Vandens kapiliarinio kilimo greičio $(\mathrm{m} / \mathrm{s})$ modeliavimo rezultatai skirtingose pušies medienos bioanglies frakcijose: a) stambioje; b) vidutineje; c) smulkioje

Fig. 3.44. Modelling results for the water capillary rise rate $(\mathrm{m} / \mathrm{s})$ in different pine wood biochar fractions: a) coarse; b) medium; c) fine

Smulkiausios frakcijos bioanglies eksperimentinis, modifikuoto Luko ir Vašburno modelio bei kompiuterinio modelio kapiliarinis pakilimo aukštis buvo 
didesnis, lyginant su stambios ir vidutinès frakcijos (3.45 pav.). Kuo mažesnès yra bioanglies dalelès, tuo vandens pakilimo aukštis yra didesnis. Eksperimentinius rezultatus geriau atitiko modifikuoto Luko ir Vašburno modelio rezultatai nei kompiuterinio modelio. Remiantis modifikuoto Luko ir Vašburno modelio rezultatais, vandens pakilimas praejus $28800 \mathrm{~s}$ smulkiausioje frakcijoje buvo $7,58 \%$ didesnis, lyginant su eksperimentine verte; vidutinès frakcijos atveju $13,9 \%$ didesnis, o stambios $-13,2 \%$ didesnis. Remiantis multifazès tekejjimo poringaja medžiaga modelio, atitinkamai $2,53 \%, 56,7 \%$ ir $61,5 \%$ mažesnis, lyginant su eksperimento vertèmis.

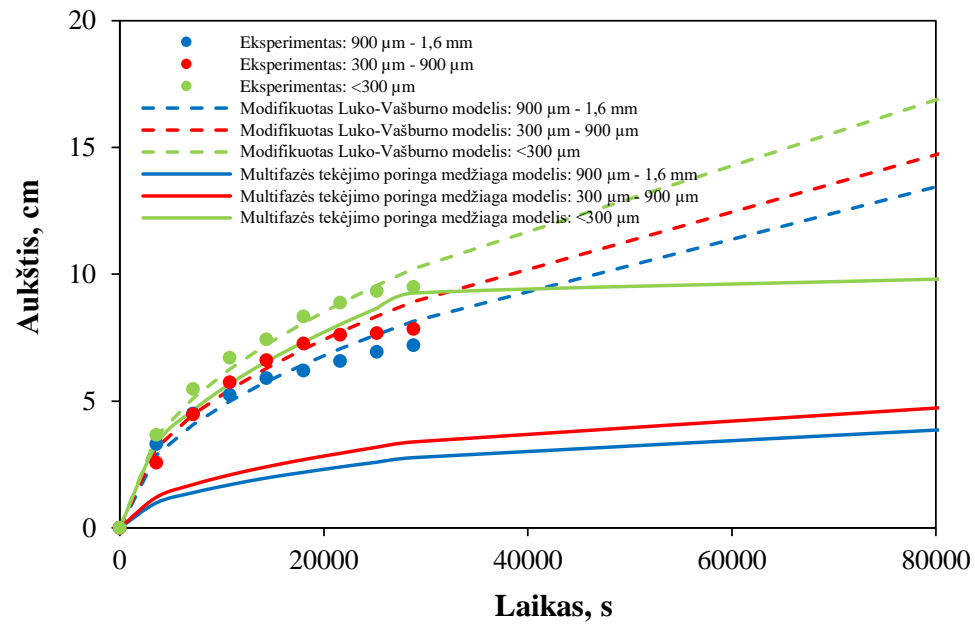

3.45 pav. Kapiliarinio kilimo greičio $(\mathrm{cm} / \mathrm{s})$ eksperimentiniai (taškinè linija), modifikuoto Luko ir Vašburno modelio (punktyrinè linija) ir multifazès tekèjimo poringaja medžiaga modelio (ištisinè linija) rezultatai priklausomai nuo bioanglies frakcijos, $n=3$

Fig. 3.45. Experimental results of capillary rise rate $(\mathrm{cm} / \mathrm{s})$ (dotted line), modified Lucas-Washburn model (dashed line) and multiphase flow in porous material model (solid line) depending on biochar fraction, $n=3$

Vertinant, kaip kinta bioanglies tūrinis brinkimas priklausomai nuo skirtingu bioanglies frakcijų, smulkiausia pušies medienos bioanglis brinko daugiausia $(5,3 \%)$, o stambiausia - mažiausiai $(2,5 \%)$. Panašiai smulkesnès frakcijos bioanglies poringumas buvo didesnis ( $82 \%)$ nei stambios frakcijos $(77 \%)$. Nepaisant panašios medžiagų cheminès sudèties, poringesnè medžiaga (su didesniu SPP) turi didesnę gebą išbrinkti nei mažesnio poringumo medžiaga (Sienkiewicz et al., 2017). Yra nedidelis skirtumas tarp santykinai didelių ir mažų medžiagos dalelių brinkimo. 
Buvo atliktas $600 \mathrm{~min}$. multifazès tekèjimo poringaja medžiaga modeliavimas vandens ir stambios frakcijos pušies medienos, pušies žievès ir kanapių bioanglies atvejais (3.46 pav.). Nustatyta, kad praejus $36000 \mathrm{~s}$ stambios frakcijos pušies medienos bioanglis buvo prisotinta vandeniu iki $3,1 \mathrm{~cm}$ aukščio (3.44a pav.), pušies žievès - iki 1,09 cm (3.46a pav.) ir kanapių - iki 7,62 cm (3.46b pav.). Matyti, kad kanapiu bioanglies vandens kapiliarinis kilimas buvo geriausias, ir taip galèjo būti dèl jos mažiausio kontakto laipsnio $\left(65^{\circ}\right)$ ir didžiausio poringumo (86 \%), lyginant su kitomis frakcijomis.

a)

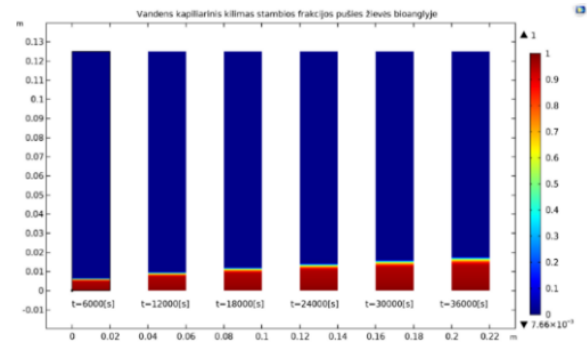

b)

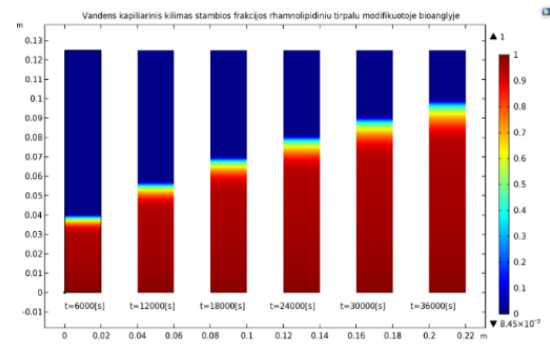

3.46 pav. Multifazės tekèjimo poringaja medžiaga modelio vandens kapiliarinio kilimo greičio $(\mathrm{m} / \mathrm{s})$ rezultatai skirtingos žaliavos bioanglies tipuose: a) pušies žievès;

b) kanapių

Fig. 3.46. Results of capillary rise rate $(\mathrm{m} / \mathrm{s})$ of water in the multiphase flow porous material model using different biochar types: a) pine bark; b) hemp

Iš visų žaliavų eksperimento pradžioje (iki 8 val. arba 28800 s) didžiausias kapiliarinio kilimo aukštis $(9 \mathrm{~cm})$ buvo būdingas kanapių bioangliai $(3.47$ pav.). Modifikuoto Luko ir Vašburno modelio ir multifazès tekejjimo poringaja medžiaga modelio rezultatai taip pat parodè, kad kanapių bioanglis eksperimento pradžioje (po 8 val.) pasižymèjo didžiausiu pakilimo aukščiu (atitinkamai $10 \mathrm{~cm}$ ir $6,82 \mathrm{~cm}$ ). Tokius rezultatus galëjo lemti didesnis kanapių bioanglies poringumas $(86 \%)$, drèkumas $\left(65^{\circ}\right)$ ir brinkimas $(3 \%)$. Skirtingos pradinès žaliavos rikiuojasi tokia tvarka: kanapès $>$ pušies mediena $>$ pušies žievè. Tokị žaliavų eiliškumą daugiausia galèjo lemti bioanglies poringumas: kanapès (86 \%) $>$ pušies mediena $(77 \%)>$ pušies žievè $(65 \%)$. Bioanglies poringumas gali varijuoti nuo 55 iki $86 \%$ ir daugiausia priklauso nuo jos pradinès žaliavos (mediena < žolè) (Brewer et al., 2014). Panašiai kaip ir bioanglies frakcijų atveju, eksperimentinius rezultatus geriau atitiko modifikuoto Luko ir Vašburno modelio rezultatai nei kompiuterinio modelio. Modifikuoto Luko ir Vašburno modelio vandens pakilimas praejjus $28800 \mathrm{~s}$ pušies medienos bioanglyje buvo 3,89 \% didesnis, lyginant su eksperimentine verte; pušies žievès ir kanapių bioanglies atvejais - atitinkamai 9,85 \% ir 15,5 \% mažesnis. Remiantis multifazès tekejjimo 
poringaja medžiaga modeliu, atitinkamai $65,5 \%, 85,3 \%$ ir 21,3 \% mažesnis, lyginant su eksperimento vertėmis.

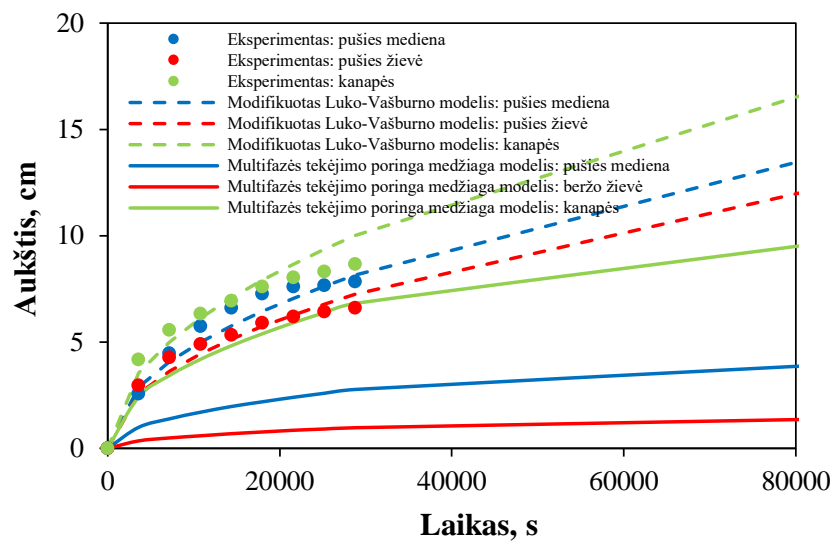

3.47 pav. Kapiliarinio kilimo greičio $(\mathrm{cm} / \mathrm{s})$ eksperimentiniai (taškinè linija), modifikuoto Luko ir Vašburno modelio (punktyrinè linija) ir multifazės tekejjimo poringaja medžiaga modelio (ištisinè linija) rezultatai priklausomai nuo bioanglies pradinès žaliavos, $n=3$

Fig. 3.47. Experimental results of capillary rise rate $(\mathrm{cm} / \mathrm{s})$ (dotted line), modified Lucas-Washburn model (dashed line), and the multiphase flow in porous material model (solid line) depending on biochar initial feedstock, $n=3$

Šie rezultatai patvirtina mintị, kad didesnio poringumo medžiagos lemia didesni kapiliarinio kilimo greiti (Cai et al., 2014). Taip ir šiame tyrime poringiausia medžiaga (kanapès, poringumas - $86 \%$ ) tiek eksperimentiškai, tiek remiantis multifazès tekejjimo poringaja medžiaga modeliu turèjo didžiausią kapiliarinio kilimo greitị ( $9 \mathrm{~cm}$ per 8 val.), lyginant su kitų žaliavų bioanglimi. Remiantis multifazès tekèjimo poringaja medžiaga modelio rezultatais, po 8 val. kanapių bioanglies pakilimo aukštis siekė $8,67 \mathrm{~cm}$, o pušies medienos ir žievès bioanglies - atitinkamai $7,83 \mathrm{~cm}$ ir $6,6 \mathrm{~cm}$. Taip pat svarbus kapiliarinio kilimo aukščio veiksnys yra porų skersmuo, kuris šiame tyrime buvo didesnis kanapių atveju $(29,7 \mu \mathrm{m})$, nei lyginant su pušies medienos ar žievès (atitinkamai 20,2 ir $24,7 \mu \mathrm{m}$ ). Panašiai ankstesniais tyrimais (Tsunazawa et al., 2016) nustatyta, kad modeliuotas kapiliarinis kilimas didesnio dirvožemio kapiliarų skersmens atveju buvo aukštesnis nei mažų porų. Šiame tyrime dirvožemio dalelès, kurios turèjo didesni vidutini kapiliarų spinduli $(10 \mu \mathrm{m})$, pasižymèjo kur kas aukštesniu modeliuotu pakilimo aukščiu $(12,5 \mathrm{~cm}>2,5 \mathrm{~cm})$ nei mažo kapiliarų spindulio $(0,35 \mu \mathrm{m})$ dalelès, praèjus $10 \mathrm{~min}$.

Šiame tyrime kapiliarinio kilimo kreives galima skirstyti ị dvi zonas: greito kilimo zoną iki 8 val. ir stabilią zoną po to laiko. Ši savybè patvirtina teorinę 
analizę, kad gravitacinès jègos poveikis kapiliarinio kilimo metu gali būti neittraukiamas pradinèse stadijose, prognozuojamose Vašburno lygtimi (Zeng et al., 2017). Pradinèse stadijose kapiliarinis kilimo aukštis yra proporcingas laiko kvadratinei šakniai $\left(h(t) \approx t^{1 / 2}\right)$, tačiau kai skystis toliau kyla, gravitacijos poveikis igauna didesnę reikšmę ir kapiliarinio kilimo kinetika sumažeja nuo $h(t) \approx t^{1 / 2}$ iki $h(t) \approx t^{1 / 3}$.

Buvo atliktas $600 \mathrm{~min}$. multifazès tekèjimo poringaja medžiaga modeliavimas vandens ir modifikuotos lietaus vandens garais ir modifikuotos ramnolipidinio tirpalo garais bioanglies atvejais. Nustatyta, kad praejus $36000 \mathrm{~s}$ modifikuota lietaus vandens garais bioanglis buvo prisotinta vandeniu iki $6,14 \mathrm{~cm}$ aukščio (3.48a pav.), o ramnolipdinio tirpalo garais - iki 7,13 cm (3.48b pav.). Matyti, kad modifikuota ramnolipidinio tirpalo garais bioanglis pasižymejjo geresniu vandens pakilimu ir tai galèjo lemti jos mažiausias kontakto laipsnis $\left(54^{\circ}\right)$ ir kapiliaro spindulys $\left(1,05 \cdot 10^{-5} \mathrm{~m}\right)$ bei didžiausias poringumas $(79 \%)$, lyginant su kitomis modifikacijomis.

a)

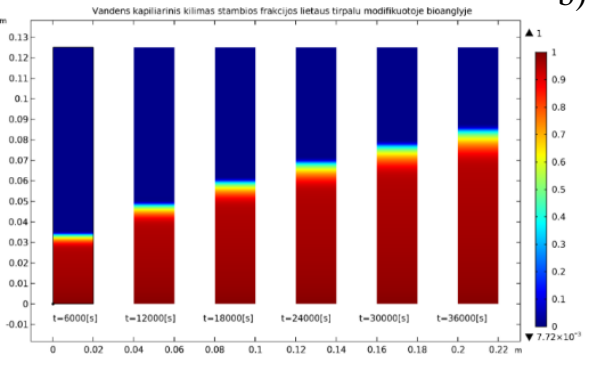

b)

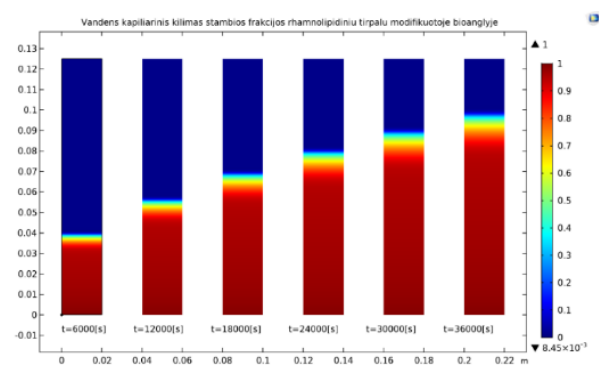

3.48 pav. Multifazès tekejjimo poringaja medžiaga modelio vandens kapiliarinio kilimo greitis (m/s) skirtingo bioanglies modifikuojančio tirpalo garų atveju: a) lietaus vandens;

b) ramnolipidinio tirpalo

Fig. 3.48. Capillary rise rate $(\mathrm{m} / \mathrm{s})$ of water in modified biochar according to the multiphase flow porous model in the case of steam of different solutions: a) rainwater;

b) rhamnolipid solution

Vertinant vandens kapiliarini pakilimo aukšti nemodifikuotoje ir modifikuotoje tirpalų garais bioanglyje, matyti, kad tiek eksperimentiškai, tiek teoriškai gautais rezultatais modifikuotuose pušies medienos bioanglies tipuose jis yra kiek didesnis, lyginant su nepaveikta bioanglimi (3.49 pav.). Eksperimentinius rezultatus geriau atitiko modifikuoto Luko ir Vašburno modelio rezultatai nei multifazès tekèjimo poringaja medžiaga modelio. Teoriškai vandens pakilimas praejus $28800 \mathrm{~s}$ lietaus vandens garais modifikuotoje bioanglyje buvo $0,99 \%$ didesnis, lyginant su eksperimentine 
verte; ramnolipidinio tirpalo garais modifikuotos bioanglies atveju - 3,9\% mažesnis. Remiantis multifazès tekèjimo poringaja medžiaga modeliu, atitinkamai $32,2 \%$, ir 22,2 \% mažesnis, lyginant su eksperimento vertemis.
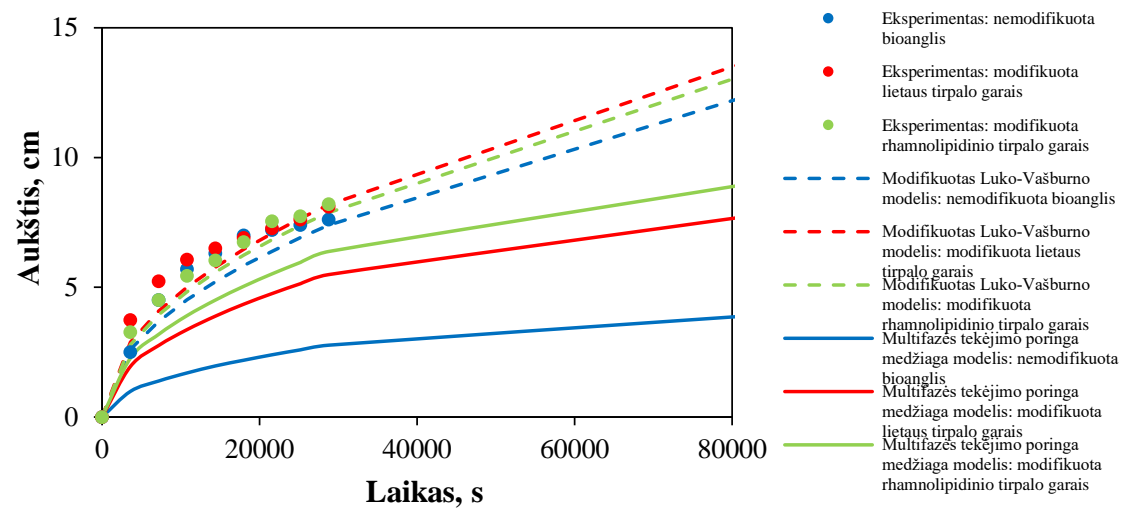

3.49 pav. Kapiliarinio kilimo greičio $(\mathrm{cm} / \mathrm{s})$ eksperimentiniai (grafike pavaizduota taškais), modifikuoto Luko ir Vašburno modelio (punktyrinè linija) ir multifazès tekejimo poringaja medžiaga modelio (ištisinè linija) rezultatai priklausomai nuo skirtingo bioanglies modifikuojančio tirpalo garų, $n=3$

Fig. 3.49. Experimental results of capillary rise rate $(\mathrm{cm} / \mathrm{s})$ (dotted line), modified Lucas-Washburn model (dashed line), and the multiphase porous material flow model (solid line) depending on the steam of different biochar modifying solutions, $n=3$

Taigi, buvo pasiūlyta modifikuota Luko ir Vašburno lygtis, kuria galima modeliuoti skysčio kapiliarini pakilimo aukšti bioanglyje, kuri sugeria skysčius ir brinksta. Pateiktame modelyje buvo atsižvelgta į beveik visas poringos terpès ir skysčio savybes, kurios kontroliuoja savaiminio sudrékimo (kapiliarinio kilimo) procesą; šiame modelyje buvo atsižvelgta ne tik ị medžiagos ir skysčio masę skysčio kapiliarinio kilimo metu, bet ir ị tūrinį bioanglies dalelių brinkimą, apie kurị anksčiau nebuvo minèta literatūroje, kalbant apie skysčio kapiliarinị kilimą išbrinkusioje bioanglyje. Modeliuojant skysčio kapiliarinị kilimo greiti, galima atsižvelgti i efektyvaus kapiliaro spindulio pokytị brinkimo metu, išbrinkusių kapiliarų spindulị ir bioanglies tūrinį brinkimą. Kaip matyti iš gautų SEM paveikslų, bioanglis turi nevienodą porų dydžio pasiskirstymą priklausomai nuo pradinès žaliavos. Taigi, matematinis modelis, apimantis kompozito parametrą, susijusi su srauto vingiuotumu ir poringos terpès porų forma, buvo pritaikytas skirtingų porų apertūrų formų lignoceliuliozinèje bioanglyje. Eksperimento rezultatai parodè skirtingus pradinių bioanglies žaliavų (pušies medienos, kanapių, pušies žievès) ir jos frakcijų (smulkių, vidutinių ir stambių) kapiliarinio kilimo bruožus. Buvo ịrodyta, kad didesnis bioanglies tūrinis brinkimas (5\%), 
poringumas (86\%), drèkumas $\left(65^{\circ}\right.$ kontakto laipsnis) ir vidutinis porų spindulys $\left(1,48 \cdot 10^{-5} \mathrm{~m}\right)$ yra palankesnis didesniam skysčio kapiliariniam pakilimo aukščiui, praejjus tam tikram laiko tarpui. Esant didesniam vidutiniam poru spinduliui, padidèjo ir vandens kapiliarinis kilimo greitis. Lyginant skirtingas frakcijas, smulkios bioanglies $(<300 \mu \mathrm{m})$ pakilimo greitis buvo didžiausias, lyginant su vidutinemis ir stambiomis frakcijomis. Siūlomas modifikuotas Luko ir Vašburno modelis buvo patvirtintas trumpalaikiam (iki 8 val.) skysčio kapiliarinio kilimo greičiui, tačiau modelis nebuvo tinkamas ilgalaikiam (24 val.) greičiui modeliuoti. Lyginant modifikuoto Luko ir Vašburno modelio ir multifazès tekejjimo poringaja medžiaga modelio rezultatus su eksperimentiniais, modifikuoto Luko ir Vašburno modelio rezultatai geriau atitiko eksperimentinius.

\subsection{Bioanglies modifikacijos garais inžineriniai sprendimai}

Atlikus kompleksinius eksperimentinius ir teorinius tyrimus, sukurtas bioanglies hidrofiliškumo didinimo įrenginys. Šis ịrenginys skirtas bioanglies hidrofiliškumo didinimo įrenginiams, konkrečiai - vakuuminiams įrenginiams, skirtiems slėgio pokyčiams tarp bioanglies dalelių sukurti ir skysčių infiltracijai ir eksfiltracijai iš bioanglies porų didinti, dèl to yra paveikiamas tiek išorinis, tiek vidinis porų paviršius. Dèl to didejja bioanglies geba sulaikyti vandenį. Tokia modifikuota bioanglis gali būti naudojama daugelyje aplinkosaugos technologijų, ịtraukiant biofiltraciją. Yra gautas patentas „Bioanglies hidrofiliškumo didinimo įrenginys ir būdas" (Valstybinis patentų biuras, patento Nr. LT 6661) (Baltrènas et al., 2019).

Tradiciniai bioanglies hidrofiliškumo didinimo įrenginiai turi trūkumą siūloma bioangli modifikuoti tirpalu. Priešingai nei garai, skystis paveikia tik išrorinị porų paviršiaus plotą ir tik mažą dalị vidinio ploto. Bioanglies aktyvacija garais gali padidinti bioanglies hidrofiliškumą dèl: 1) paviršiaus ploto didinimo, nes modifikacijos metu yra išlaisvinami kondensuoti junginiai, užkemšantys bioanglies poras; 2) mikroporingumo didinimo dèl mažų porų susijungimo bei vidinių ertmių didinimo; 3) bioanglies porų paviršiaus oksidacijos, dèl ko susiformuoja paviršiaus rūgštinès deguonies turinčios funkcinès grupès. Kita trūkumas yra tas, kad bioanglị siūloma modifikuoti cheminių paviršiaus aktyviujų medžiagų tirpalais, kurie yra toksiški. Tokiai modifikacijai naudojamas iki 100 kartų didesnis cheminių medžiagų kiekis, lyginant su biologinèmis paviršiaus aktyviosiomis medžiagomis. Šiai problemai spręsti reikia modifikuoti tokių ịrenginių konstrukciją. Bioanglies hidrofiliškumo didinimo įrenginio brěžinys pateiktas 3.50 paveiksle. 


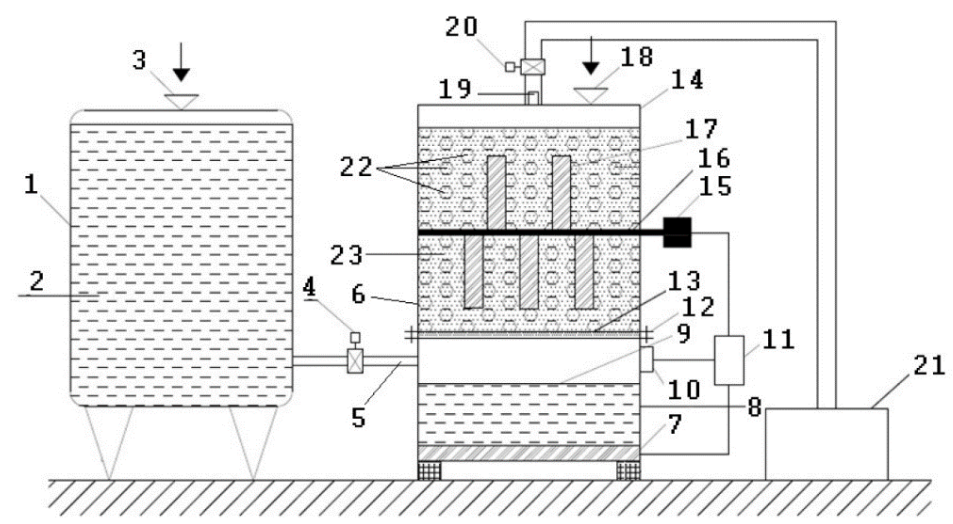

3.50 pav. Bioanglies hidrofiliškumo didinimo įrenginio schema: 1 - ramnolipidinès medžiagos tirpalo talpykla; 2 - ramnolipidinès medžiagos tirpalas; 3 - tirpalo užpildymo anga; 4 - sklendè; 5 - žarnelè; 6 - bioanglies vakuuminio apdorojimo talpykla; 7 - kaitinimo elementas; 8 - apatinè vakuuminio apdorojimo talpyklos dalis; 9 - ramnolipidinès medžiagos tirpalas; 10 - temperatūros daviklis; 11 - automatinis valdymo blokas; 12 - flanšinè jungtis su tarpikliu; 13 - perforuota pertvara; 14 - viršutinè vakuuminio apdorojimo talpyklos dalis; 15 - elektros variklis; 16 - velenas; 17 - maišymo mentès; 18 - bioanglies įdejjimo anga; 19 - antgalis; 20 - sklende்; 21 - vakuuminè pompa; 22 - bioanglies dalelès; 23 - tirpalo garai (Baltrènas et al., 2019)

Fig. 3.50. Scheme of the device for enhancement of biochar hydrophilicity: 1 - chamber for the solution of the rhamnolipid material; 2 - rhamnolipid solution; 3 - filling opening; 4 - valve; 5 - hose; 6 - biochar vacuum treatment chamber; 7 - heating element; 8 - lower part of the vacuum treatment chamber; 9 - rhamnolipid solution; 10 - temperature sensor; 11 - automatic control block; 12 - flange connection with a gasket; 13 - perforated partition; 14 - upper part of the vacuum treatment chamber; 15 - electric motor; 16 - shaft; 17 - mixing blades; 18 - opening for biochar feeding; 19 - nipple; 20 - valve; 21 - vacuum pump; 22 - biochar particles; 23 - steam of the solution (Baltrènas et al., 2019)

Irenginio veikimo principą sudaro tai, kad visų pirma ramnolipidinès medžiagos tirpalas iš tirpalo talpyklos (1) per sklendę (4) tiekiamas ị apatinę vakuuminio apdorojimo talpyklos dali (6). Kaitinimo elementu (7) tirpalas apatinejje apdorojimo talpykloje yra pakaitinimas iki virimo temperatūros siekiant gauti maksimaliai $(100 \%)$ prisotintą orą. Oro temperatūra vakuuminio apdorojimo talpykloje pamatuojama temperatūros davikliu (10), sujungtu su automatiniu valdymo bloku (11), kuris reguliuoja automatinị kaitinimo elemento išjungimą. Automatinis valdymo blokas (11) taip pat reguliuoja nenutrūkstamą maišyklès, susidedančios iš elektrinio variklio (15), veleno (16) ir strypelių pavidalo menčiu (17), darbą. Kai bioanglis (22) yra modifikuojama, kondensuoti 
junginiai išlaisvinami iš išorinès ir vidinès bioanglies struktūros, todèl yra skatinami ramnolipidinio tirpalo garų mainai su vidine bioanglies struktūra. Perforuota pertvara (13) skirta tam, kad būtų galima išvengti bioanglies dalelių (22) patekimo ị ramnolipidinès medžiagos tirpalą (9). Kai bioanglis (22) yra prisotinama garais, viršutineje vakuuminio apdorojimo talpyklos dalyje (6) yra sukuriamas vakuumas (99 990-1333 Pa) naudojant vakuuminę pompą (21). Bioanglis laikoma vakuume 2,5-3 val. Vakuumas pagreitina skysčiu infiltraciją ir eksfiltraciją iš bioanglies porų. Sukurtas bandomasis bioanglies hidrofiliškumo didinimo įrenginys pavaizduotas 3.51 paveiksle.

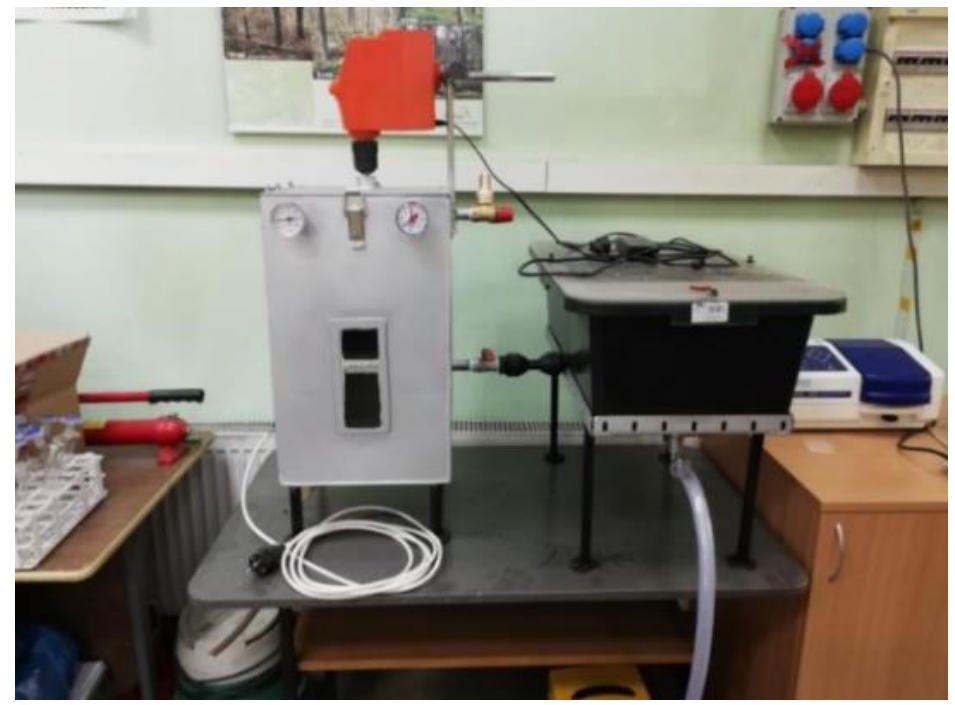

3.51 pav. Bioanglies hidrofiliškumo didinimo ịrenginys (autorès nuotrauka)

Fig. 3.51. Device for enhancing biochar hydrophilicity (author's photo)

Nuo kitų panašių įrenginių šis hidrofiliškumo didinimo įrenginys skiriasi tuo, kad turi kaitinimo elementą, irengtą apatinèje apdorojimo talpos dalyje, perforuotą pertvarą, atskiriančią vakuuminès talpyklos viršutinę dali (užpildytą bioanglimi) nuo apatinès dalies, vakuuminę pompą, skirtą vakuumo ir pseudosluoksnio bioanglyje sukūrimui. Apatinè apdorojimo talpyklos dalis yra užpildoma ramnolipidiniu tirpalu iki $60 \%$ jos tūrio. Bioanglies frakcija ịrenginyje - 2-4 mm. Ramnolipidinès medžiagos koncentracija vandenyje - 30$40 \mathrm{mg}$. Bioanglis maišoma maišykle viršutineje apdorojimo talpyklos dalyje nuo 2,5 iki 3 valandų. Kaitinimo elemento ir maišyklès darbą reguliuoja temperatūros daviklis per automatinị valdymo bloką. 


\subsection{Trečiojo skyriaus išvados}

1. Kapiliarinị kilimo procesą bioanglyje galima skirstyti ị dvi fazes: trumpą (iki 8 valandu), kai nèra įtraukiamas gravitacijos poveikis, ir ilgą (nuo 8 valandų), kai šis poveikis turètų būti įtraukiamas. Maksimali santykinè vandens paklaida trumpam kapiliarinio kilimo laikui (iki 5 val.) siekia 4,4\% naudojant kanapių bioanglị. Modifikuoto Luko ir Vašburno modelio pagrịstumas, esant trumpam kapiliarinio kilimo laikui (iki 5 val.), buvo verifikuotas.

2. Smulkiausios frakcijos pušies medienos bioanglies $(<300 \mu \mathrm{m})$ kapiliarinio kilimo aukštis yra didžiausias, kuris, remiantis eksperimentu, siekia $9,5 \mathrm{~cm}$ praejjus 8 valandoms. Tokị rezultatą lemia $5 \%$ didesnis poringumas, $5,95 \%$-drèkumas ir 50\% - tūrinis brinkimas, lyginant su stambia frakcija. Kanapių bioanglis pasižymi didžiausiu vandens pakilimu, kuris eksperimentiškai siekè $8,67 \mathrm{~cm}$. Tai galima sieti su $21 \%$ didesniu poringumu, 15,5\%-kapiliarų spinduliu ir $27 \%$-drèkumu

3. Didejjant temperatūrai nuo 300 iki $700{ }^{\circ} \mathrm{C}$, pušies medienos bioanglies $\mathrm{pH}$ didèja $24,5 \%$, pelenų kiekis $-85,5 \%$, C kiekis - 6,62 \%, savitasis paviršiaus plotas $-98,7 \%$, bendrasis poru tūris - 98,2\%, mikroporu tūris - $100 \%$ bei drèkumas - 99,9 \%. Pušies medienos bioanglies išeiga mažejja $61,5 \%$, elektrinis laidis - 9,47\%, vandens laikomoji geba $-52,7 \%$, O kiekis - $75 \%$, H kiekis $55,4 \%$, N kiekis $-88,8 \%$, vidutinis porų dydis $-81,1 \%$. Drèkumo didejjimas siejamas su alifatiniu grupių garavimu.

4. Remiantis daugialypès regresinès analizès rezultatais, galima teigti, kad ịvairiatemperatūrès $\left(300-700{ }^{\circ} \mathrm{C}\right)$ lignoceliuliozinès bioanglies drèkumo $54 \%$ variacijos gali būti prognozuojama vidutiniu porų dydžiu. Koreliacijos koeficientas, taikant ši modeli, siekè 0,73 , o $p$ vertè $-0,02$. Bioanglies vandens laikomosios gebos $77 \%$ variacijos gali būti prognozuojama remiantis jos peleningumu. Koreliacijos koeficientas šio modelio atveju siekè 0,87 , o $p$ vertè 0,001 .

5. Ypač didelis hidrofobiškumas būdingas žematemperatūriams $\left(300^{\circ} \mathrm{C}\right)$ beržo ir pušies žievès bioanglies tipams (atitinkamai 12480 ir 9600 s). Ypač didelị pušies ir beržo žievès bioanglies tipų hidrofobiškumą galima sieti su žaliavos lipofilinėmis medžiagomis, kurios sudaro $20 \%$ sausos žievès masès.

6. Pušies ir beržo žievès bioanglies hidrofobiškumas yra atspariausias temperatūros poveikiui, kuris išnyksta tik $600{ }^{\circ} \mathrm{C}$ temperatūroje, o pušies medienos ir kanapių - palyginti žemoje $350^{\circ} \mathrm{C}$ temperatūroje. Beržo medienos bioanglis visame temperatūrų intervale yra nežymiai hidrofobiška arba hidrofiliška. Hidrofiliškumas siejamas su mažesniu kontakto laipsniu $\left(75,8^{\circ}\right.$, pušies mediena, $\left.700^{\circ} \mathrm{C}\right)$, o hidrofobiškumas - su didesniu $\left(107^{\circ}\right.$, beržo žievè, $\left.450{ }^{\circ} \mathrm{C}\right)$. 
7. Smulkiausia beržo žievès bioanglies frakcija $(<300 \mu \mathrm{m})$ pasižymi drèkumu (vandens lašelio skverbimosi laikas - $3 \mathrm{~s}$ ), kai vidutinè $(300-900 \mu \mathrm{m})$ ir stambi $(900 \mu \mathrm{m}-1,6 \mathrm{~mm})$ frakcijos buvo ypač hidrofobiškos (atitinkamai 6120 ir $18541 \mathrm{~s})$. Mažesnių dalelių dydžių bioanglis turi daugiau suardytų vidinių makroporų, kurios didina sulaikomo vandens kiekị ant bioanglies paviršiaus.

8. 1 valandos trukmès beržo žievès bioanglies poveikis $20 \mathrm{mg} / \mathrm{l}$ ramnolipidinio tirpalo garais lemia didesnio savitojo paviršiaus ploto $\left(15,2 \mathrm{~m}^{2} / \mathrm{g}\right)$ ir mikroporų paviršiaus ploto $\left(14,4 \mathrm{~m}^{2} / \mathrm{g}\right)$ susidarymą, lyginant su nemodifikuota bioanglimi. Po modifikacijos garais ant jos paviršiaus atsiranda daugiau hidroksilinių $(-\mathrm{OH})$, karbonilinių $(\mathrm{C}=\mathrm{O})$ ir karbokslinių $(-\mathrm{COOH})$ funkcinių grupių, kurias žymi pikai atitinkamai ties $3421-3433 \mathrm{~cm}^{-1}, 1697-1699 \mathrm{~cm}^{-1}$ ir $1592-1599 \mathrm{~cm}^{-1}$ bangos skaičiais.

9. Po beržo žievès bioanglies poveikio azoto rūgšties tirpalu atsiranda azotą ir deguoni turinčių funkciniu grupių $\left(\mathrm{N}=\mathrm{O}, 1385 \mathrm{~cm}^{-1}\right)$. Deguonį ir azotą turinčios funkcinès grupès ant bioanglies paviršiaus teikia pagrindines aktyvias vietas adsorbcijai.

10. Nustatyta, kad, naudojant nemodifikuotos pušies medienos bioanglị ir plaušą, acetono, ksileno ir amoniako šalinimo efektyvumas siekia atitinkamai $84 \%, 69 \%$ ir $79 \%$, o naudojant ramnolipidinio tirpalo garais modifikuotą pušies medienos bioangli jis yra didesnis ir siekia atitinkamai $93 \%, 72 \%$ ir $96 \%$.

11. Tiek nemodifikuotos, tiek modifikuotos pušies medienos bioanglies ir plaušo bioįkrovos atvejais ksileno pašalinimo efektyvumas yra mažesnis, lyginant su acetono ir amoniako. Tai galima sieti su ksileno nepoliškumu ir didesne Henrio konstanta $\left(7,18 \cdot 10^{-3} \mathrm{~atm}-\mathrm{m}^{3} / \mathrm{mol}\right)$. Hidrofobiniai junginiai (kaip kad ksilenas) turi ribotą masès pernašą dèl vandens sluoksnio, supančio bioplèvelę, pasipriešinimo.

12. Smèlingasis lengvojo priemolio rudžemis, nepriklausomai nuo tyrimo laiko, žemès dirbimo ir tręšimo sistemos bei pušies medienos bioanglies normų, pasižymi hidrofiliškumu (VLSL $\leq 1 \mathrm{~s}$ ). Hidrofiliška dirvožemio tendencija sietina su molekulinès spektrometrijos rezultatais, kurie parodè dirvožemio struktūroje esant kaolinito (pikai ties 3626 ir $3416 \mathrm{~cm}^{-1}$ bangos skaičiais) bei aliumosilikatų mineralų, kurie yra hidrofiliški.

13. Tiesioginè sẻja lemia šių fizikinių ir cheminių savybių didèjimą visu tiriamuoju laikotarpiu: vandens laikomosios gebos, drègmès kiekio, $\mathrm{pH}$ ir organinès medžiagos. Naudojant tiesioginę sèją, tręšimą mineralinėmis azoto, fosforo ir kalio trąšomis bei $15 \mathrm{t} / \mathrm{ha}$ pušies medienos bioanglies normą, po 3 mėnesių labiausiai padidèja dirvožemio vandens laikomoji geba $(32,5 \%)$ ir $\mathrm{pH}$ $(17,6 \%)$, o po 6 mènesiu - drègmès kiekis (304 \%) ir organinès medžiagos kiekis $(62,6 \%)$. 



\section{Bendrosios išvados}

1. Remiantis modifikuoto Luko ir Vašburno modelio ir eksperimentiniais vandens kapiliarinio kilimo greičio rezultatais, modelis, itraukiantis kompozito parametrą, apibūdinantị porų formą bei srovès vingiuotumą, energijos praradimo koeficientą, tūrinị brinkimą ir išbrinkusio kapiliaro spindulị, gali būti taikomas trumpo (iki 5 val.) kapiliarinio kilimo greičio prognozei lignoceliuliozinèje bioanglyje.

2. Kanapių bioanglis pasižymi didesniu vandens kapiliariniu kilimu, lyginant su kitomis žaliavomis, kuris eksperimentiškai ir remiantis modifikuotu Luko ir Vašburno modeliu siekia 8,67 ir $10 \mathrm{~cm}$ praejjus 8 valandoms. Tai siejama su $21 \%$ didesniu medžiagos poringumu, 15,5\% didesniu vidutiniu kapiliarų spinduliu ir $27 \%$ didesniu drèkumu, lyginant su pušies žievès bioanglimi. Smulkiausia bioanglis $(<300 \mu \mathrm{m})$ pasižymi didesniu kilimo aukščiu, kuris atitinkamai siekia 9,5 ir 10,2 cm. Tai galëjo lemti $5 \%$ didesnis poringumas, $5,95 \%$ didesnis drëkumas ir $50 \%$ didesnis tūrinis brinkimas, lyginant su stambios frakcijos bioanglimi.

3. Didejjant temperatūrai nuo $300{ }^{\circ} \mathrm{C}$ iki $700{ }^{\circ} \mathrm{C}$, pušies medienos bioanglies pH didèja 24,5 \%, pelenų kiekis $-85,5 \%$, C kiekis $-6,62 \%$, savitasis paviršiaus 
plotas - 98,7\%, bendrasis porų tūris - 98,2 \%, mikroporų tūris - $100 \%$ bei drèkumas - 99,9 \%. Pušies medienos bioanglies išeiga mažèja $61,5 \%$, elektrinis laidis - 9,47\%, vandens laikomoji geba $-52,7 \%$, O kiekis $-75 \%$, H kiekis $55,4 \%$, N kiekis - 88,8 \%, vidutinis porų dydis $-81,1 \%$. Hidrofiliška bioanglis pasigamina aukštesnèje nei $500{ }^{\circ} \mathrm{C}$ temperatūroje dèl staigaus savitojo paviršiaus ploto didejjimo bei alifatinių grupių garavimo.

4. Lignoceliuliozinès bioanglies hidrofobiškumas priklausomai nuo žaliavos prarandamas skirtingose temperatūrose: naudojant pušies medieną ir kanapes jis išnyksta žemoje $350^{\circ} \mathrm{C}$ temperatūroje, o naudojant pušies ir beržo žieves jis yra atspariausias ir išnyksta tik $600{ }^{\circ} \mathrm{C}$ temperatūroje. Tai siejama su skirtinga biomasių biochemine sudètimi (celiuliozès, hemiceliuliozès ir lignino komponentų kiekiu).

5. Beržo medienos bioanglis yra hidrofiliškiausia, nes visame temperatūros intervale pasižymi mažiausiu vandens lašelio skverbimosi laiku (nuo 2,47 iki $2,33 \mathrm{~s})$. Pušies ir beržo žievès bioanglis $\left(300^{\circ} \mathrm{C}\right)$ pasižymi ypač dideliu hidrofobiškumu (12 480 ir $9600 \mathrm{~s}$, atitinkamai), kuris siejasi su lipofiliniais junginiais, randamais pradinèje žaliavoje (iki $20 \%$ ). Daugialypè regresinè analizè parodè, kad $77 \%$ bioanglies vandens laikomosios gebos variacijos gali būti prognozuojama remiantis jos pelenu kiekiu, o $54 \%$ jos drèkumo variacijos vidutiniu poru dydžiu. Pirmojo modelio atveju koreliacijos koeficientas siekè 0,87 , o $p$ vertè - 0,001, o antrojo - atitinkamai 0,73 ir 0,02 .

6. Pirsono koreliacinè analizė parodè visų trijų drèkumo metodų tinkamumą bioanglies drèkumui vertinti dèl stiprios $(0,4 \leq r \geq 0,69$ arba $-0,4 \leq r \geq-0,69)$ arba labai stiprios koreliacijos ( $r \geq 0,7$ arba $r \leq-0,7)$. Vandens lašelio skverbimosi laiko testas laikomas tinkamiausiu, nes skirtingų bioanglies tipų drékumas buvo plačių ribų (nuo hidrofiliškos (1 s) iki labai hidrofobiškos (1904 s)), ko neparodė kiti testai. Hidrofiliškumas siejasi su mažesniais kontakto laipsniais $\left(75,8^{\circ}\right.$, pušies mediena, $\left.700^{\circ} \mathrm{C}\right)$, o hidrofobiškumas - su didesniais $\left(107^{\circ}\right.$, beržo žievè, $\left.450^{\circ} \mathrm{C}\right)$.

7. Mažejant bioanglies frakcijai, beržo žievès bioanglies drèkumas didejja ir, esant $<300 \mu \mathrm{m}$ dydžiui, jis yra didžiausias $(3 \mathrm{~s})$. Bioanglies poveikis ramnolipidinio tirpalo $(20 \mathrm{mg} / \mathrm{l})$ garais turi didžiausią poveiki jos paviršiaus ploto didejjimui $\left(15,2 \mathrm{~m}^{2} / \mathrm{g}\right)$. Šio bioanglies tipo didžiają dali porų sudaro mikroporos (iki $95 \%$ mikroporu plotas sudaro bendrojo ploto). Modifikacija lemia tokių funkcinių grupių, kaip hidroksilinès $\left(3421 \mathrm{~cm}^{-1}\right)$, karboksilinès $\mathrm{C}=\mathrm{O}\left(1599 \mathrm{~cm}^{-1}\right)$, aromatinès $\mathrm{C}=\mathrm{C}\left(1431 \mathrm{~cm}^{-1}\right)$, aromatinès $\mathrm{C}-\mathrm{H}\left(876 \mathrm{~cm}^{-1}\right)$ didžiausius absorbcijos intensyvumus, kurių susidarymas didina bioanglies hidrofiliškumą.

8. Beržo žievès bioanglis, modifikuota $20 \%$ azoto rūgšties tirpalu, pasižymi didžiausiu drèkumu $(3907 \mathrm{~s})$, savituoju paviršiaus plotu $\left(4,36 \mathrm{~m}^{2} / \mathrm{g}\right)$, mikroporų tūriu $\left(0,0008 \mathrm{~cm}^{3} / \mathrm{g}\right)$ bei deguoni ir azotą turinčiu funkcinių grupių išsivystymu (pikai ties $3411 \mathrm{~cm}^{-1}, 1606 \mathrm{~cm}^{-1}$ ir $1385 \mathrm{~cm}^{-1}$ bangos skaičiais), lyginant su beržo žievès bioanglies tipais, modifikuotais $40 \%$ ir $65 \%$ azoto rūgšties tirpalais. 
9. Naudojant ramnolipidinio tirpalo garais modifikuotą pušies medienos bioanglies ir plaušo bioịkrovą, pasiekiamas didesnis acetono, ksileno ir amoniako junginių išvalymo efektyvumas, ypač polinio amoniako atveju (atitinkamai $93 \%$, $72 \%$ ir $96 \%$ ). Amoniako šalinimo efektyvumas biofiltre didejja iki 17,6 procentinių vienetų.

10. Tirtas smėlingasis lengvojo priemolio rudžemis, nepriklausomai nuo tyrimo laiko, žemès dirbimo ir tręšimo sistemos bei pušies medienos bioanglies normu, pasižymi hidrofiliškumu (VLSL $\leq 1 \mathrm{~s}$ ), kuris gali sietis su kaolinito (pikai ties 3626 ir $3416 \mathrm{~cm}^{-1}$ bangos skaičiais) bei aliumosilikatų mineralais (pikai ties 1023 ir $466 \mathrm{~cm}^{-1}$ bangos skaičiais), kurie iš prigimties yra hidrofiliški. Naudojant tiesioginę sèją, tręšiant mineralinėmis trąšomis bei ịterpiant $15 \mathrm{t} / \mathrm{ha}$ bioanglies normą, po 3 mènesių labiausiai padidèja dirvožemio vandens laikomoji geba $(32,5 \%)$ ir $\mathrm{pH}(17,6 \%)$, o po 6 ménesių - drègmès kiekis $(304 \%)$ ir organinès medžiagos kiekis $(62,6 \%)$. 



\section{Rekomendacijos}

1. Norint gauti hidrofobišką bioangli tolesnei jos modifikacijai, rekomenduojama ją gaminti žemesnejje nei $500^{\circ} \mathrm{C}$ pirolizès temperatūroje. Tai yra riba, žemiau kurios bioanglies $\left(400^{\circ} \mathrm{C}\right)$ savitasis paviršiaus plotas yra gerokai mažesnis (iki 38 kartų pušies medienos bioanglies atveju) bei turi alifatinę funkcinę grupę (pikas ties $2850 \mathrm{~cm}^{-1}$ ), kuri siejasi su bioanglies hidrofobiškumu. Žievès (pušies arba beržo) bioanglis pasižymi mažesniu drėkumu, savituoju paviršiaus plotu, mikroporų tūriu ir didesniu peleningumu, dẻl ko tokia bioanglis yra tinkama jos hidrofiliškumui didinti.

2. Siūloma žematemperatūrę $\left(450^{\circ} \mathrm{C}\right)$ beržo žievès bioanglị modifikuoti $20 \mathrm{mg} / \mathrm{l}$ ramnolipidinio tirpalo garais 1 valandą bioanglies hidrofiliškumo didinimo įrenginyje, nes tokia bioanglis turi didesni bendrajj savitaji paviršiaus ir mikroporų paviršiaus plotą, reikalingą amoniako garų sorbcijai iš užteršto oro srauto.

3. Tiesioginè sejja, tręšimas mineralinèmis azoto, fosforo ir kalio trąšomis bei 15 t/ha pušies medienos bioanglies įterpimo norma yra tinkama dirvožemio vandens laikomajai gebai $(32,5 \%), \mathrm{pH}(17,6 \%)$, drègmès kiekiui (304 \%) ir organinès medžiagos kiekiui (62,6\%) didinti. 



\section{Literatūros sąrašas}

Abdulrazzaq, H.; Jol, H.; Husni, A.; Abu-Bakr, R. 2014. Characterization and stabilisation of biochars obtained from empty fruit bunch, wood, and rice husk, BioResources 9(2): 2888-2898.

Agrafioti, E.; Bouras, G.; Kalderis, D.; Diamadopoulosa, E. 2012. Sewage sludge as a precursor for biochar production, in Third International Conference on Industrial and Hazardous Waste Management, Crete, 7.

Ahmed, M. B.; Zhou, J. L.; Ngo, H. H.; Guo, W. 2016. Insight into biochar properties and its cost analysis, Biomass and Bioenergy 84: 76-86.

Aplinkos apsaugos agentūra 2020. Oro tarša Lietuvoje. I aplinkos orą išmetamų teršalų analizė ir pasiskirstymas ūkio sektoriuose 2005-2018 m. Informacinè santrauka, Vilnius. Ardjmand, M.; Safekordi, A.; Farjadfard, S. 2005. Simulation of biofilter for removal of air contaminants (ethanol), International Journal of Environmental Science and Technology 2(1): 69-82.

Aston, S.; Stret-Perrott, A.; Doerr, S. 2014. Factors influencing biochar hydrophobicity and the influence of biochar content on the hydrological and erosional response of a slit loam under simulated rainfall, Geophysical Reseacrh Abstracts V. 16.

Ataskaita 2016. Tolimųjų oro teršalų pernašų iš kitų valstybių poveikio bendram Lietuvos oro baseino užterštumo lygiui Lietuvoje ịvertinimas 2016. Užsakomojo darbo ataskaita. 
Atkinson, C. J.; Fitzgerald, J. D.; Hipps, N. A. 2010. Potential mechanisms for achieving agricultural benefits from biochar application to temperate soils: a review, Plant and Soil 337(1-2): 1-18.

Baltrènaitė, E.; Baltrènas, P.; Bhatnagar, A.; Vilppo, T.; Selenius, M.; Koistinen, A.; Dahl, M.; Penttinen, O.-P. 2017. A multicomponent approach to using waste-derived biochar in biofiltration: A case study based on dissimilar types of waste, International Biodeterioration and Biodegradation 119: 565-576.

Baltrènas, P.; Baltrènaitè, E.; Kleiza, J.; Švedienė, J. 2016. A bichar-based medium in the biofiltration system: removal efficiency, microorganism propagation, and the medium penetration modeling, Journal of the air and waste management association 66(7): 673686.

Baltrènas, P.; Baltrènaite, E.; Spudulis, E. 2015. Biochar from pine and birch morphology and pore structure change by treatment in biofilter, Water, air and soil pollution 226: 69.

Baltrènas P.; Mačaitis K 2014. Effectiveness of air treatment using a plate-type biofilter with a capillary system for humidification of packing material, Environmental Engineering and Management Journal 13(8): 2063-2072.

Biria, D.; Maghsoudi, E.; Roostaazad, R. 2013. Application of biosurfactants to wettability alteration and IFT reduction in enhanced oil recovery from oil-wet carbonates, Petroleum Science and Technology 32(12): 1259-1267.

Bontchev, R.; Kim, H. S.; Wilson, R. W.; Belcher, R. W.; Cheyne, C.; Manzer, L. E.; Jarand, M. L.; Wan. H.; Malyala, R. 201612 22. Enhanced biochar. US patent No. 62/162, 219.

Branco, F. R.; Gil, N. A. 2017. NMR study of carbonates wettability, Journal of petroleum science and engineerring 157: 288-294.

Bravo, D.; Ferrero, P.; Penya-Roja, J. M.; Alvarez-Fornos, F. J.; Gabaldon, C. 2017. Control of VOCs from printing press air emissions by anaerobic bioscrubber: performance and microbial community of an on-site pilot unit, Journal of Environmental Management 197: 287-295.

Brewer, C. E.; Chuang, V. J.; Masiello, C. A.; Gonnermann, H.; Gao, X.; Dugan, B.; Driver, L. E.; Panzacchi, P.; Zygourakis, K.; Davies, C. A. 2014. New approaches to measuring biochar density and porosity, Biomass and Bioenergy 66: 176-185.

Brewer, C. E. 2012. Biochar characterization and engineering. Doctoral dissertation, Iowa State University, 1-197.

Brischke, C.; Wegener, F. L. 2019. Impact of water holding capacity and moisture content of soil substrates on the moisture content of wood terrestrial microcosms, Forests 10(6): 485.

Brownsort 2009. Biomass pyrolysis processes: review of scope, control and variability, UKBRC Working paper.

Bruneel, J.; Walgraeve, C.; Mukurarinda, J.; Boon, N.; Van Langenhove, H. 2018. Biofiltration of hexane, acetone and dimethyl sulphide using wood, compost and silicone foam, Journal of Chemical Technology and Biotechnology 93(8): 2234-2243. 
Bubici, S.; Korb, J.-P.; Kučerik, J.; Conte, P. 2016. Evaluation of the surface affinity of water in three biochars using fast field cycling NMR relaxometry, Magnetic Resonance in Chemistry 54: 365-370.

Buivydaitè, V.; Motuzas, A. 2000. Dirvožemio organinė medžiaga ir humusas. Geologijos ir dirvotyros laboratoriniai darbai.

Cai, J.; Perfect, E.; Cheng, C.-L.; Hu, X. 2014. Generalized modeling of spontaneous imbibition based on Hagen-Poiseuille flow in tortuous capillaries with variably shaped apertures, Langmuir 30: 5142-5151.

Cheng, Y.; He, H.; Yang, Ch.; Zeng, G.; Li, X.; Chen, H.; Yu, G. 2016. Challenges and solutions for biofiltration of hydrophobic volatile organic compounds, Biotechnology Advances 34(6): 1091-1102.

Colon, J.; Martinez-Blanco, J.; Gabarrell, X.; Rieradevall, J.; Font, X.; Artola, A.; Sanchez A. 2009. Performance of an industrial bifilter from a composting plant in the removal of ammonia and VOCs after material replacement, Journal of Chemical Technology and Bioetchnology 84(8): 1111-1117.

Conte, P.; Nestle, N. 2015. Water dynamics in different biochar fractions, Magnetic Resonance in Chemistry 53(9): 726-34.

Conz, R. F.; Abbruzzini, T. F.; Andrade, C. A.; Milori, D. M. B. P.; Cerri, C. E. P. 2017. Effect of pyrolysis temperature and feedstock type on agricultural properties and stability of biochars, Agricultural Sciences 8: 914-933.

Crombie, K.; Masek, O.; Sohi, S. P.; Brownsort, P.; Cross, A. 2013. The effect of pyrolysis conditions on biochar stability as determined by three methods, GCB Bioenergy 5: 122131.

Das, O.; Sarmah, A. K. 2015. The love-hate relationship of pyrolysis biochar and water: a perspective, Science of the total environment 512-513: 682-685.

Daukšas, K.; Barkauskas, J.; Daukšas, V. 2003. Chemijos terminų aiškinamasis žodynas, mokslo ir enciklopedijų leidybos institutas, $659 \mathrm{psl}$.

Depalo, A.; Santomaso, A. C. 2013. Wetting dynamics and contact angles of powders studied through capillary rise experiments, Colloids and Surfaces A: Physicochemical and Engineering Aspects 436: 371-379.

Deshusses M.A.; Johnson C.T. 2000. Development and validation of a simple protocol to rapidly determine the performance of biofilters for VOC treatment, Environmental Science and Technology 34(3): 461-467.

Dieguez-Alonso, A.; Funke, A.; Anca-Couce, A.; Rombola, A. G.; Ojeda, G.; Bachmann, J.; Behrendt, F. 2018. Towards biochar and hydrochar engineering - influence of process conditions on surface physical and chemical properties, thermal stability, nutrient availability, toxicity and wettability, Energies 11(3): 496.

Domingues, R. R.; Trugilho, P. F.; Silva, C. A.; de Melo, I. C. N. A.; Melo, L. C. A.; Magriotis, Z. M.; Sanchez-Monedero 2017. Properties of biochar derived from wood and high-nutrient biomasses with the aim of agronomic and environmental benefits, Plos One 12(5): e0176884. 
Dorado, A. D.; Lafuente, F. J.; Gabriel, D.; Gamisans, X. 2010. A comparative study based on physical charactersitics of suitable packing materials in biofiltration, Environmental Technology 31(2): 193-204.

EBC, 2012. European Biochar Certificate - Guidelines for a sustainable production of biochar. European Biochar Foundation (EBC), Arbaz, Switzerland. http//http://www.european-biochar.org/en. Version 6.3E of 14th August 2017: http://www.european-biochar.org/en/download\%20the\%20certificate.

Elnour, A. Y.; Alghyamah, A. A.; Shaikh, H. M.; Poulose, A. M.; Al-Zahrani, S. M.; Anis, A.; Al-Wabel, M. I. 2019. Effect of pyrolyi temperature on biochar microstructural evolution, physicochemical characteristics, and its influence on biochar/polypropylene composites, Applied Sciences 9(6): 1149.

Environment Agency 2013. Biofilter performance and operation as related to commercial composting, Bristol, $11 \mathrm{p}$.

Gabriel, D.; Maestre, J. P.; Martin, L.; Gamisans, X.; Lafuente, J. 2007. Characterisation and performance of coconut fibre as packing material in the removal of ammonia in gasphase biofilters, Biosystems Engineering 97(4): 481-490.

Gezahegn, S.; Sain, M.; Thomas, S. C. 2019. Variation in feedstock wood chemistry strongly influences biochar liming potential, Soil Sciences 3(2): 26.

Giffin, S.; Littke, R.; Klaver, J.; Urai, J. L. 2013. Application of BIB-SEM technology to characterize macropore morphology in coal, International Journal of Coal Geology 114: 85-95.

Glab, T.; Palmowska, J.; Zaleski, T.; Gondek, K. 2016. Effect of biochar application on soil hydrological properties and physical quality of sandy soil, Geoderma 281: 11-20.

Gondim, R. S.; Celli, R.; Muniz, C. R.; Eduardo, C. 2018. Explaining the water-holding capacity of biochar by scanning electron microscope images, Revista Caatinga 31(4): 972-979.

Gosselin, D.; Berthier, J.; Chaussy, D.; Belgacem, N. 2015. Capillary flows: Dynamics and geometry effects, Proceedings of COMSOL conference in Grenoble.

Gray, M.; Johnson, M. G.; Dragila, M. I.; Kleber, M. 2014. Water uptake in biochars: the roles of porosity and hydrophobicity, Biomass and Bioenergy 61: 196-205.

Guzel, F.; Saygili, H.; Saygili, G. A.; Koyuncu, F.; Yilmaz, C. 2017. Optimal oxidation with nitric acid of biochar derived from pyrolysis of weeds and its application in removal of hazardous dye methylene blue from aqueous solution, Journal of Cleaner Production 144: 260-265.

Gwenzi, W.; Chaukura, N.; Noubactep, C.; Mukome, F. N. D. 2017. Biochar-based water treatment systems as a potential low-cost and sustainable technology for clean water provision, Journal of Environmental Management 197: 732-749.

Ha, J.; Kim, J.; Jung, Y.; Yun, G.; Kim, D.-N.; Kim, H.-Y. 2018. Poro-elasto-capillary wicking of cellulose sponges, Science Advances.

Hagemann, N.; Spokas, K.; Schmidt, H.-P.; Kagi, R.; Bohler, M. A.; Bucheli, T. D. 2018. Activated carbon, biochar and charcoal: linkages and synergies across pyrogenic carbon's ABC's, Water 10(182): 1-19. 
Hale, L.; Luth, M.; Crowley, D. 2015. Biochar characteristics relate to its utility as an alternative soil inoculum carrier to peat and vermiculite, Soil biology and chemistry 81: 228-235.

Hallin, I. L.; Douglas, P.; Doerr, S. H.; Bryant, R. 2015. The effect of addition of a wettable biochar on soil water repellency, European Journal of Soil Science 66: 10631073.

Herath, H. M. S. K. 2012. Stability of biochar and its influence on the Dynamics of soil properties. Doctoral theses, Massey University, New Zealand 10-18.

Hilber, I.; Bastos, A. C.; Loureiro, S.; Soja, G.; Marsz, A.; Cornelissen, G.; Bucheli, T. D. 2017. The different faces of biochar: contamination risk versus remediation tool, Journal of Environmental Engineering and Landscape Management 25(02): 86-104.

Hirt, C. W. 2017. Surface tension validation - simple test problems, Flow Science, Inc.

Huang, H.; Tang, J.; Gao, K.; He, R.; Zhao, H.; Werner, D. 2017. Characterization of $\mathrm{KOH}$ modified biochars from different pyrolysis temperatures and enhanced adsorption of antibiotics, RSC Advances 7: 14640-14648.

Inyang, M. I. 2013. Engineered biochars for the removal of metallic, organic and emerging contaminants from aqueous solutions. Dissertation, University of Florida, 19-21 p.

Jafri, N.; Wong, W. Y.; Doshi, V.; Yoon, L. W.; Cheah, K. H. 2018. A review on production and characterization of biochars for application in direct carbon fuel cells, Process Safety and Environmental Protection 118: 152-166.

Jeffery, S.; Meinders, M. B. J.; Stoof, C. R.; Bezemer, T. M.; van de Voorde, T. F. J.; Mommer, L.; van Groenigen, J. W. 2015. Biochar application does not improve the soil hydrological function of a sandy soil, Geoderma 251-252: 47-54.

Kambo, H. S.; Dutta, A. 2015. A comparative review of biochar and hydrochar in terms of production, physico-chemical properties and applicatins, Renewable and sustainable energy review 45: 359-378.

Kan, T.; Strezov, V.; Evans, T. J. 2016. Lignocellulosic biomass pyrolysis: a review of product properties and effects of pyrolysis parameters, Renewable and Sustainable Energy Reviews 57: 1126-1140.

Karim, R. K.; Halim, M. A.; Gale, N. V.; Thomas, S. C. 2020. Biochar effects on soil physiochemical properties in degraded managed ecosystems in Northeastern Bangladesh, Soil Systems 4(4): 69.

Kauselya, K.; Narendiran, R.; Ravi, R. 2015. Biofiltration emerging technology for removal of volatile organic compounds (VOC's) - a review, International Journal of Environment and Bioenergy 10(1): 1-8.

Kinney, T. J.; Masiello, C. A.; Dugan, B., Hockaday, W. C.; Dean, M. R.; Zygourakis, K.; Barnes, R. T. (2012). Hydrologic properties of biochars produced at different temperatures, Biomass and Bioenergy 41: 34-43.

Kochiieru, M.; Feiziene, D.; Feiza, V.; Volungevicius, J.; Velykis, A.; Slepetiene, A.; Deveikyte, I.; Seibutis, V. 2020. Freezing-thawing impact on aggregate stability as affected by land management, soil genesis and soil chemical and physical quality, Soil and Tillage Research 203: 104705. 
Kochiieru, M.; Lamorski, K.; Feiza, V.; Feizienè, D.; Volungevičius, J., 2018. The effect of soil macroporosity, temperature and water content on $\mathrm{CO}_{2}$ efflux in the soils of different genesis and land management, Zemdirbyste-Agriculture 105(4): 291-298.

Komkiene, J.; Baltrenaite, E. 2016. Biochar as adsorbent for removal of heavy metal ions [Cadmium(II), Copper(II), Lea(II), Zinc(II)] from aqueous phase, International Journal of Environmental Science and Technology 13: 471-482.

Korenkova, L.; Šimkovic, I.; Dlapa, P.; Jurani, B.; Matuš, P. 2015. Identifying the origin of soil water repellency at regional level using multiple soil characteristics: the White Carpathians and Myjavska Pahorkatina Upland case study, Soil and Water Resources 10(2): 78-89.

Kumar, R.; Tabatabaei, M.; Karimi, K.; Horvath, I. S. 2016. Recent updates on lignocellulosic biomass derived ethanol - a review, Biofuel Research Journal 9: 347-356.

Leelamanie, D. A. L.; Karube, J.; Yoshida, A. 2008. Characterizing water repellency indices: contact angle and water drop penetration time of hydrophobized sand, Soil Science and Plant Nutrition 54: 179-187.

Lehmann and Joseph 2009. Biochar for Environmental Management: Science and Technology. Available online: [https://books.google.co.kr/books?id=wCUty_JIfcC\&printsec $=$ frontcover \&source=gbs_ge_summary_r\&cad=0\#v=onepage\&q\& $\mathrm{f}=$ false.

Leng, L.; Xiong, Q.; Yang, L.; Li, H.; Zhou, Y.; Zhang, W.; Jiang, S.; Li, H.; Huang, H. 2021. An overview on engineering the surface area and porosity of biochar, Science of The Total Environment 763: 144204.

Li N.; Ma, X.; Zha, Q.; Kim, K.; Chen, Y. 2011. Maximizing the number of oxygencontaining functional groups on activated carbon by using ammonium persulfate and improving the temperature-programmed desorption characterization of carbon surface chemistry, Carbon 49(15): 5002-5013.

Li, B.; Yang, L.; Wang, C.-Q.; Zhang, Q.-P.; Liu, Q.-C.; Li, Y.-D.; Xiao, R. 2017. Adsorption of $\mathrm{Cd}$ (II) from aqueous solutions by rape straw biochar derived from different modification processes, Chemosphere 175: 332-340.

Liang, H.; Chen, L.; Liu, G.; Zheng, H. 2016. Surface morphology properties of biochars produced from different feedstocks, International Conference on Civil, Transportation and Environment (ICCTE 2016).

Liao, W.; Thomas, S. C. 2019. Biochar particle size and post-pyrolysis mechanical processing affect soil $\mathrm{pH}$, water retention capacity, and plant performance, Soil Systems 3(1): 14 .

Liu, Z.; Niu, W.; Chu, H.; Zhou, T.; Niu, Z. 2018. Effect of the carbonization temperature on the properties of biochar produced from the pyrolysis of crop residues, BioResources 13(2): 3429-3446.

Liu, Z.; Dugan, B.; Masiello, C. A.; Gonnermann, H. M. 2017. Biochar particle size, shape, and porosity act together to influence soil water properties, PloS One 12(6).

Liu, W.-J.; Jiang, H.; Yu, H.-Q. 2015. Development f biochar-based functional materials: toward a sustainable platform carbon material, Chemical Reviews 115(22): 12251-12285. 
Lou, K.; Rajapaksha, A. U.; Ok, Y. S.; Chang, S. X. 2016. Pyrolysis temperature and steam activation effects on sorption of phosfate on pine sawdust biochars in aqueous solutions, Chemical Speciation and Bioavailability 28(1-4): 42-50.

Lucas, R. 1918. Uber das Zeitgesetz des kapillaren Aufstiegs von Flussigkeiten, KolloidZeitschrift 23: 15-22.

Lu, N.; Likos, W. J. 2004. Unsaturated soil mechanics. Wiley, New York.

Mansoori, A. N.; Mori, M.; Higuchi, T. 2017. Simultaneous observations of moisture behavior and gaseous VOCs removal in biofiltration system, $15^{\text {th }}$ International Conference on Environmental Science and Technology, Rhodes, Greece, 31 August to 2 September.

Markl, D.; Yassin, S.; Wilson, D. I.; Goodwin, D. J.; Anderson, A.; Zeitler, J. A. 2017. Mathematical modelling of liquid transport in swelling pharmaceutical immediate release tablets, International Journal of Pharmaceutics 526: 1-10.

Mary, G. S.; Sugumaran, P.; Niveditha, S.; Ramalakshmi, B.; Ravichandran, P.; Seshadri, S. 2016. Porduction, characterization and evaluation of biochar from pod (Pisum sativum), leaf (Brassica oleracea) and peel (Citrus sinensis) wastes, International Journal of Recycling of Organic Waste 5: 43-53.

Mochado, D. R.; Hasson, D.; Semiat, R. 1999. Effect of solvent properties on permeate flow through nanofiltration membranes. Part I: investigation of parameters affecting solvent flux, Journal of Membrane Science 163: 93-102.

Morgado J.; Merlin G.; Gonthier Y.; Eyraud A. 2004. A mechanistic model for m-xylene treatment with peat-bed biofilter, Environmental Technology 25:123-132.

Morral, E.; Gabriel, D.; Dorado, A. D.; Gamisans, X. 2020. A review of biotechnologies for the abatement of ammonia emissions, Chemosphere 15: 128606.

Motuzas, A.J.; Buivydaitė, V.; Danilevičius, V.; Šleinys R. 1996. Dirvotyra. Vilnius: Mokslo ir enciklopedijų leidykla, 375.

Mudliar, S.; Giri, B.; Padoley, K.; Satpute, D.; Dixit, R.; Bhatt, P.; Pandey, R.; Juwarkar, A.; Vaidya, A. 2010. Bioreactors for treatment of VOCs and odours - a review, Journal of Environmental Management 91: 1039-1054.

Mukherjee, A.; Lal, R. 2013. Biochar impacts on soil physical properties and greenhouse gas emissions, Agronomy 3: 313-339.

Naeem, M. A.; Khalid, M.; Arshad, M.; Ahmad, R. 2014. Yield and nutrient composition of biochar produced from different feedstocks at varying pyrolytic temperatures, Pakistan Journal of Agricultural Sciences 51(1): 75-82.

Nartey, D. O.; Zhao, B. 2014. Biochar preparation, characterization, and adsorptive capacity and its effect on bioavailability of contaminants: an overview, Advances in Materials Science and Engineering 2014: 1-14.

National Research Council 2010. Acute exposure guideline levels for selected airborne chemicals, Washington, DC, National Academic Press. 
Nguyen, D. H.; Tran, H. N.; Chao, H.-P.; Lin, C.-C. 2019. Effect of nitric acid oxidation of hydrochars to sorb methylene blue: an adsorption mechanism comparison, Adsorption Science and Technology 37(7-8): 607-622.

Nguyen, B.T.; Lehmann, J. 2009. Black carbon decomposition under varying water regimes, Organic Geochemistry 40: 846-853.

Novotny, E. H.; de Freitas Maia, C. M. B.; de Melo Carvalho, M. T.; Madari, B. E. 2015. Biochar: pyrogenic carbon for agricultural use - a critical review, Revista Brasileira de Ciencia do Solo 39(2): 321-344.

Nsamba, H. K.; Hale, S. E.; Cornelissen, G.; Bachmann, R. T. 2015. Designing and performance evaluation of biochar production in a top-lit updraft up-scaled gasifier, Journal of Sustainable Bioenergy Systems 5(2): 41-55.

Nwajiaku, I. M.; Olanrewaju, J.; S.; Sato, K.; Tokunari, T.; Kitano, S.; Masunaga, T. 2018. Changein nutrient composition of biochar from rice husk and sugarcane bagasse at varying pyrolytic temperatures, International journal of recycling of organic waste in agriculture 7(4): 269-276.

Ojeda, G.; Mattana, S.; Avila, A.; Alcaniz, J. M.; Volkmann, M.; Bachmann, J. 2015. Are soil-water functions affected by biochar application? Geoderma 249-250: 1-11.

Okechukwu, I. K. 2019. Determination of contact angle measurement of sub-bituminous and bituminous coal particles through capillary rise method using washburn equation for surface free energy and interfacial energy, International Journal of Advances Engineering and Technology 3(2): 58-62

Oliveira, F. R.; Patel, A. K.; Jaisi, D. P.; Adhikari, S.; Lu, H.; Khanal, S. K. 2017. Environmental application of biochar: current status and perspectives, Bioresource technology 246: 110-122.

Omondi, M. O.; Xia, X.; Nahayo, A.; Liu, X.; Korai, P. K.; Pan, G. 2016. Quantification of biochar effects on soil hydrological properties using meta-analysis of literature data, Geoderma 274: 28-34.

Oni, B. A.; Oziegbe, O.; Olawole, O. O. 2019. Significance of biochar application to the environment and economy, Annals of Agricultural Sciences 64(2): 222-236.

Or, D.; Tuller, M. 2005. Capillarity, in: Encyclopedia of Soils and the Environment.

PAC 2007. Definitions of terms relating to the structure and processing of sols, gels, networks, and inorganic-organic hybrid materials. IUPAC Recommendations, 79: 1801.

PAC 2004. Definitions of terms relating to reactions of polymers and to functional polymeric materials. IUPAC Recommendations, 76: 891.

PAC 1997. Glossary of terms used in computational drug design. IUPAC Recommendations, 69: 1145.

PAC 1996. Glossary of terms in quantities and units in Clinical Chemistry. IUPAC-IFCC Recommendations, 68: 995.

PAC 1994. Glossary of terms used in physical organic chemistry. IUPAC Recommendations, 66: 1116. 
PAC 1992. Glossary for chemists of terms used in biotechnology. IUPAC Recommendations, 64: 148.

PAC 1990. Glossary of atmospheric chemistry terms. Recommendations, 62: 2215.

PAC 1972. Manual of Symbols and Terminology for Physicochemical Quantities and Units, Appendix II: Definitions, Terminology and Symbols in Colloid and Surface Chemistry. Recommendations, 31: 577.

Pagans, E.; Font, X.; Sanchez, A. 2005. Biofiltration for ammonia removal from composting exhaust gases, Chemical Engineering Journal 113(2-3): 105-110.

Page-Dumroese, D. S.; Robichaud, P. R.; Brown, R. E.; Tirocke, J. M. 2015. Water repellency of two forest soils after biochar addition, American Society of Agricultural and Biological Engineers 58(2): 335-342.

Paulauskas, A.; Jankevičius, K.; Liužinas, R.; Raškauskas, V.; Zajančkauskas, P. 2008. Ekologijos terminų aiškinamasis žodynas, Vilnius, 503 p.

Peng, J.; Wan, A. 1998. Effect of ionic strength on Henry's constants of volatile organic compound, Chemosphere 36(13): 2731-2741.

Peterson, S. C.; Jackson, M. A. 2014. Simplifying pyrolysis: using gasification to produce corn stover and wheat straw biochar for sorptive and horticultural media, Industrial Crops and Products 53: 228-235.

Pirola, C.; Mattia, M. 2021. Purification of air from volatile organic compounds by countercurrent liquid gas mass transfer absorption process, International Journal of Thermofluids 9: 100060.

Pituello, C.; Francioso, O.; Simonetti, G.; Pisi, A. 2014. Characterization of chemicalphysical, structural and morphological properties of biochars from biowastes produced at different temperatures, Journal of Soils and Sediments 15: 792-804.

Pituya, P.; Sriburi, T.; Wijitkosum, S. 2016. Properties of biochar prepared from acacia wood and coconut shell for soil amendment, Engineering Journal 21(3): 63-75.

Qayyum, M.F.; Steffens, D.; Reisenauer, H.P.; Schubert, S. 2014. Biochars influence differential distribution and chemical compostinio of soil organic matter, Plant, Soil and Environment 60(8): 337-343.

Rafiq, M. K.; Bachmann, R. T.; Rafiq, M. T.; Shang, Z.; Joseph, S.; Long, R. 2016. Influence of pyrolysis temperature on physico-chemical properties of Corn Stover (Zea mays L.) bioachar and feasibility for carbon capture and energy balance, Plos One 11(6): e0156894.

Rajapaksha, A. U.; Chen, S. S.; Tsang, D. C. W.; Zhang, M.; Vithanage, M.; Mandal, S.; Gao, B.; Bolan, N. S.; Ok, Y. S. 2016. Engineered/designer biochar for contaminant removal/immobilisation from soil and water: potential and implication of biochar modification, Chemosphere 148: 276-291.

Rao, M. A.; Simeone, G. D. S.; Scelza, R.; Conte, P. 2017. Biochar based remediation of water and soil contaminated by phenanthrene and pentachlorophenol, Chemosphere 186: 193-201. 
Revah, S.; Vergara-Fernandez, A.; Hernandez, S. 2011. Fungal biofiltration for the elimination of gaseous pollutants from air. In book: Mycofactories, pp. 109-120.

Ronsse, F.; Hecke, van S.; Dickinson, D.; Prins, W. 2013. Production and characterization of slow pyrolysis biochar: influence of feedstock types and pyrolysis conditions, Bioenergy 5(2): 104-115.

Rowen, J. W.; Gagliardi, D. 1947. Properties of water-repellent fabrics, Part of the Journal of Research of the National Bureau of Standarts 38.

Sahin, O.; Taskin, M. B.; Kaya, E. C.; Atakol, O.; Emir, E.; Inal, A.; Gunes, A. 2017. Effect of acid modification of biochar on nutrient availability and maize growth in a calcareous soil, Soil Use and Management 33: 447-456.

Saletnik, B.; Zagula, G.; Bajcar, M.; Tarapatskyy, M.; Bobula, G.; Puchalski, C. 2019. Bioachar as multifunctional component of the environment - a review, Applied sciences 9: 1139.

Shang, J.; Flury, M.; Harsh, J. B.; Zollars, R. L. 2008. Comparison of different methods to measure contact angles of soil colloids, Journal of Colloid and Interface Science 328(2): 299-307.

Shi, S.; Gardner, D. J. 2000. A new model to determine contact angles on swelling polymer particles by the column wicking method, Journal of Adhesion Science and Technology, 14(2): 301-314.

Shim, T.; Yoo, J.; Ryu, C.; Park, Y.-K.; Jung, J. 2015. Effect of steam activation of biochar produced from a giant Miscanthus on copper sorption and toxicity, Bioresource Technology 197: 85-90.

Sienkiewicz, A.; Krasucka, P.; Charmas, B.; Stefaniak, W.; Goworek, J. 2017. Swelling effects in cross-linked polymers by thermogravimetry, Journal of Thermal Analysis and Calorimetry 130: 85-93.

Siipola, V.; Pflugmacher, S.; Romar, H.; Wendling, L.; Koukkari, P. 2020. Low-cost biochar adsorbents for water purification including microplastics removal, Applied Sciences 10(3): 788.

Singh, R. K.; Ramteke, D. S.; Juneja, H. D.; Pandya, G. H. 2013. Ambient Air Quality Monitoring in Terms of Volatile Organic Compounds (VOCs) Occupational Health Exposure at Petroleum Refinery, International Journal of Environmental Protection 3(7): 22-32.

Sizmur, T.; Fresno, T.; Akgul, G.; Frost, H.; Moreno-Jimenez, E. 2017. Biochar modification to enhance sorption of inorganics from water, Bioresource Technology 246: 34-47.

Smetanova, A.; Dotterweich, D.; Ulrich, U.; Fohrer, N. 2013. Influence of biochar and terra preta substrates on wettability and erodibility of soild, Zeitschrift Fur Geomorphologie 57: 111-134.

Solar, J.; Marco, I. de Caballero, B. M.; Lopez-Urionabarrenechea, A.; Rodriguez, N.; Agirre, I.; Adrados, A. 2016. Influence f temperature and residence time in the pyrolysis of woody biomass waste in a continuous screw reactor, Biomass and bioenergy 95: 416423. 
Stevenson, W. 2016. Evaluating soaking times on the hydrophobicity of biochar using the water droplet penetration time method, the soil fertility project, University of Amsterdam. Suliman, W.; Harsh, J. B.; Abu-Lail, N. I.; Fortuna, A.-M.; Dallmeyer, I.; Garcia-Perez, M. 2017. The role of biochar porosity and surface functionality in augmenting hydrologic properties of a sandy soil, Science of The Total Environment 574: 139-147.

Suliman, W.; Harsh, J. B.; Abu-Lail, N. I.; Fortuna, A.-M.; Dallmeyer, I.; Garcia-Perez, M. 2016. Influence of feedstock source and pyrolysis temperature on biochar bulk and surface properties, Biomass and bioenergy 84: 37-48.

Sun, X.; Shan, R.; Li, X.; Pan, J.; Liu, X.; Deng, R.; Song, J. 2017. Characterization of 60 types of Chinese biomass waste and resultant biochars in terms of their candidacy for soil spplication, GCB Bioenergy 9: 1423-1435.

Tan, I. A. W.; Abdullah, M. O.; Lim, L. L. P.; Yeo, T. H. C. 2017. Surface modification and characterization of coconut shell-based activated carbon subjected to acidic and alkaline treatments, Journal of Applied Science and Progress Engineering 4(2): 186-194.

Tsang, Y. F.; Wang, Y.; Wang, H.; Yang, Y.; Zhang, Y.; Chua, H. 2017. Biodegradation of ammonia in biofiltration systems: changes of metabolic products and microbial communities. In book: Nitrification and Denitrification. DOI: 10.5772/intechopen.68155.

Tsunazawa, Y.; Yokoyama, T.; Nishiyama, N. 2016. An experimental study on the rate and mechanism of capillary rise in sandstone, Progress in Earth and Planetary Science 3: 8.

Unece 2019. Assessment report on ammonia - 2019.

Vantieghem, S. 2016. Carbon dioxide sequestration by means of biochar: analytical pyrolysis as a stability proxy method, master dessertation, 9-10 p.

Vigouroux 2001. Pyrolysis of biomass. Dissertation, Royal Institute of Technology, Stockholm.

Vinš, V.; Hruby, J.; Hykl, J.; Blaha, J.; Šmid, B. 2013. Design of an experimental apparatus for measurement of the surface tension of metastable fluids, EPJ Web of Conferences 45.

Voelkner, A.; Holthusen, D.; Ellerbrock, R. H.; Horn, R. 2015. Quantity of hydrophobic functional $\mathrm{CH}$-groups - decisive for soil water repellency caused by digestate amendment, International Agrophysics 29: 247-255.

Vu, K. A.; Tawiq, K.; Chen, G. 2015. Rhamnolipid transport in biochar-amended agricultural soil, Water, Air and Soil Pollution 226(8): 226-256.

Wang, Y.; Xiao, X.; Chen, B. 2018. Biochar impacts on soil silicon dissolution kinetics and their interaction mechanisms, Scientific Reports 8(1): 8040.

Wangler, J.; Kohlus, R. 2017. Dynamics of capillary wetting of biopolymer powders, Chemical Engineering Technology 40(9): 1552-1560.

Washburn, E. W. 1921. The Dynamics of Capillary Flow, Physical Review (17)3: 273283.

Weber, K.; Quicker, P. 2018. Properties of biochar, Fuel 217: 240-261. 
Werdin, J.; Fletcher, T. D.; Rayner, J. P.; Williams, N. S. G.; Farrell, C. 2020. Biochar made from low density wood has greater plant available water than biochar made from high density wood, Science of the total Environment 705: 135856.

Williams, D. L.; Kuhn, A. T.; Amann, M. A.; Hausinger, M. B.; Konarik, M. M.; Nesselrode, E. I. 2010. Computerized measurement of contact angles, Galvanotechnik 111.

Wolak, E.; Vogt, E.; Szczurowski, J. 2017. Chemical and hydrophobic modification of activated WD-axtra carbon, Energy and fuels 14.

Woschnagg, E.; Cipan, J. 2004. Evaluating forecast accuracy, 406347 Okonometrische Prognose, University of Vienna, Department of Economics.

Xiu, S.; Shahbazi, A.; Li, R. 2017. Characterizatin, modification and application of biochar for energy storage and catalysis: a review, Trends in renewable energy 3(1): 86101.

$\mathrm{Xu}, \mathrm{H}$; Guetari, C. 2004. The use of CFD to simulate capillary rise and comparison to experimental data, ANSYS INC.

Yakout, S. M. 2015. Monitoring the changes of chemical properties of rice straw-derived biochars modified by different oxidizing agents and their adsorptive performance for organics, Bioremediation Journal 19(2): 171-182.

Yakout, S. M.; Daifullah, A. E. H. M.; El-Reefy, S. A. 2015. Pore structure characterization of chemically modified biochar derived from rice straw, Environmental Engineering and Management Journal 14(2): 473-480.

Yang, W.; Shang, J.; Baoguo, L.; Flury, M. 2019. Surface and colloid properties of biochar and implications for transoprt in porous media, Critical Reviews in Environmental Science and Technology 50(23): 2484-2522.

Yuan, Y.; Lee, T. R. 2013. Contact angle and wetting properties, Surface Science Techniques 51: 3-34.

Yu, O. Y.; Raichle, B.; Sink, S. 2013. Impact of biochar on the water holding capacity of loamy sandy soil, International Journal of Energy and Environmental Engineering 4(1): 44.

Yuan, P.; Wang, J.; Pan, Y.; Shen, B.; Wu, C. 2019. Review of biochar for the management of contaminated soil: preparation, application and prospect, Science of The Total Environment 659: 473-490.

Zagorskis, A.; Baltrènas, P.; Vasarevičius, S.; Rimeika, M. 2012. Investigations on the sustainability of a biofilter with activated packing materials of different origins, Environmental Engineering and Management Journal 11(4): 773-782.

Zemfira, T.; Milanovskiy, E. 2015. The contact angle of wetting of the solid phase of soil before and after chemical modification, Eurasian Journal of Soil Science 4(3): 191-197.

Zeng, Y.; Tian, S.; Pan, Y. 2018. Revealing the sources of atmospheric ammonia: a review, Air Pollution 4: 189-197. 
Zeng, J.; Lin, L.; Tang, Y.; Sun, Y.; Yuan, W. 2017. Fabrication and capillary characterization of micro-grooved wicks with reetrant cavity array, International Journal of Heat and Mass Transfer 104: 918-929.

Zhang, H. 2016. Biochar characteristics and effects on phosphorus availability and dynamics in tropical soils, doctoral thesis, Australia.

Zhang, J.; You, C. 2013. Water holding capacity and absorption properties of wood shars, Energy Fuels 27(5): 2643-2648.

Zhang, J.; Zhang, L.; Sun, Q.; Yang, P. 2008. Removal of high concentration of ammonia gas in a hybrid biofilter. Published in: 2008 2nd International Conference on Bioinformatics and Biomedical Engineering.

Zhang, Z.; Zhu, Z.; Shen, B.; Liu, L. 2019. Insights into biochar and hydrochar production and applications: a review, Energy 171: 581-598.

Zhao, J. J.; Shen, X.-S.; Domene, X.; Alcaniz, J.-M.; Liao, X.; Palet, C. 2019. Comparison of biochars derived from different types of feedstock and their potential for heavy metal removal in multiple-metal solutions, Scientific Reports 9: 9869.

Zhao, S.-X.; Ta, N.; Wang, X.-D. 2017. Effect of temperature on the structural and physicochemical properties of biochar with apple tree branches as feedstock material, Energies 10(9): 1293.

Zhao, L.; Cao, X.; Mašek, O.; Zimmerman, A. 2013. Heterogeneity of biochar properties as a function of feedstock sources and production temperatures, Journal of Hazardous Materials 256-257: 1-9.

Zhu, R.; Li, S.; Wu, Z.; Dumont, E. 2016. Performance evaluation of a slow-release packing material-embedded functional microrganisms in biofiltration, Environmental Technology 38(8): 945-955.

Zornoza, R.; Moreno-Barriga, F.; Acosta, J. A.; Munoz, M. A.; Faz, A. 2016. Stability, nutrient availability and hydrophobicity of biochars derived from manure, crop residues, and municipal solid waste for their use as soil amendments, Chemosphere 144: 122-130. 



\section{Autorès mokslinių publikacijų disertacijos tema sąrašas}

\section{Straipsniai recenzuojamuose mokslo žurnaluose}

Usevičiūtè, L.; Baltrènaitè-Gedienè, E. 2021. Modelling of a capillary rise height of biochar by modified Lucas-Washburn equation, Environmental Modeling and Assessment (Clarivate Analytics Web of Science, DOI: https://doi.org/10.1007/s10666-021-09782$6)$.

Usevičiūtè, L.; Baltrènaitè-Gedienė, E.; Baltrėnas, P. 2021. Hydrophilicity enhancement of low-temperature lignocellulosic biochar modified by physical-chemical techniques, Journal of Material Cycles and Waste Management 23(5): 1838-1854 (Clarivate Analytics Web of Science).

Usevičiūtè, L.; Baltrènaitė-Gedienė, E. 2020. Dependence of pyrolysis temperature and lignocellulosic physical-chemical properties of biochar on its wettability, Biomass Conversion and Biorefinery (Clarivate Analytics Web of Science, DOI: https://doi.org/10.1007/s13399-020-00711-3).

Usevičiūtè, L.; Baltrènaitè, E. 2020. Methods for determing lignocellulosic biochar wettability, Waste and Biomass Valorization 11: 4457-4468 (Clarivate Analytics Web of Science).

Usevičiūtè, L.; Baltrėnaitè, E. 2019. Application of pyrogenic carbonaceous product for immobilisation of potentially toxic elements in railway sleepers and polluted soil, 
International Journal of Environmental Science and Technology 16(1): 23-36 (Clarivate Analytics Web of Science).

\section{Patentai}

Baltrènas, P.; Baltrènaitė, E.; Usevičiūtè, L. 201803 23. Bioanglies hidrofiliškumo didinimo ịrenginys ir büdas. Lietuvos patentas Nr. 6661. Lietuvos Respublikos valstybinis patentų biuras. 


\section{Summary in English}

\section{Introduction}

\section{Formulation of the problem}

Phenomena related to water interactions that occur only on hydrophilic surfaces have recently been observed on biochar surfaces as well. Biochar, like black coal produced from forestry waste, is initially hydrophobic. The hydrophobicity may prevent water from penetrating into the inner pores of the biochar. The hydrophobicity of biochar is not constant over time and, although biochar is initially hydrophobic, it can become hydrophilic after a certain period of time (e.g. one year). Therefore, wettability of biochar is not constant and is not yet well understood.

Biochar produced at temperatures above $500{ }^{\circ} \mathrm{C}$ was found to be more hydrophilic than those produced at lower temperatures. On the other hand, the production of biochar at high temperatures is a costly process. For this reason, there is a need to produce biochar at the lowest possible pyrolysis temperatures and to reduce energy consumption in the intensive pyrolysis process which is used to produce hydrophilic biochar.

\section{Relevance of the thesis}

Biochar is receiving an increasing attention from scientists for its potential role in carbon sequestration, greenhouse gas reduction, renewable energy, waste reduction, and soil improvement. It is currently being extensively studied for its application in agriculture, 
effect on increased cereal yields, improved soil properties. The ecotoxicological effects of biochar, understanding of nutrients' transport and harmful biochar compounds, the impact of feedstock and pyrolysis conditions on the main properties of biochar are areas that need more attention in the future.

There is a need to gain more knowledge about the development of engineered biochar based on the feedstock and pyrolysis processes. The impact of biochar on the soil environment, including its physical and chemical properties, is still not well understood and more research is needed on this.

\section{The object of the research}

Interaction of hydrophobic low-temperature $\left(450^{\circ} \mathrm{C}\right)$ lignocellulosic biochar with aqueous solutions is the object of the research.

\section{The aim of the thesis}

The aim of this work is to evaluate the interaction of low-temperature lignocellulosic biochar with solutions to increase its hydrophilicity.

\section{The task of the thesis}

In order to achieve the aim, the following tasks need to be solved:

1. Using a modified Lucas-Washburn model, to evaluate the rate of capillary rise of organic and inorganic liquids in lignocellulosic biochar.

2. To determine the physicochemical properties of lignocellulosic biochar produced under low temperature $\left(300-500{ }^{\circ} \mathrm{C}\right)$ pyrolysis conditions and its connection to wettability and water holding capacity.

3. To apply different methods for wettability determination of low-temperature lignocellulosic biochar.

4. To reduce hydrophobicity of low-temperature biochar $\left(450^{\circ} \mathrm{C}\right)$ by nonaggressive to environment modification techniques (steam of rainwater, steam of rhamnolipid solution).

5. To compare the effect of modified and unmodified biochar on the efficiency of removal of volatile organic and inorganic pollutants in a biofilter with a capillary irrigation system.

6. To evaluate wettability changes of soil, amended with lignocellulosic biochar under field conditions.

7. To evaluate the rate of water capillary rise in lignocellulosic biochar using the modified Lucas-Washburn model and multiphase transport in porous material model. 


\section{Research methodology}

The methodologies were applied for theoretical, experimental, and numerical modelling studies to determine biochar wettability and estimate the capillary rise rate of liquids in biochar (by modified Lucas-Washburn model, Brooks and Corey model with Darsi law), to experimentally evaluate physico-chemical properties of biochar depending on temperature, wettability (by water droplet penetration time test, molarity of ethanol droplet test, contact angle analysis), to evaluate changes in biochar properties after its modification by physical (steam of rhamnolipid solution and rainwater) and chemical (nitric acid) methods, to determine efficiency of removal of volatile organic and inorganic pollutants in the biofilter filled with unmodified and steam modified biochar, and to increase physicochemical properties of the soil.

\section{Scientific novelty of the thesis}

The method was developed for the determination of biochar wettability. The mathematical model for the prediction of liquid capillary rise height was modified including volumetric biochar swelling, radius of swelled capillary.

\section{Practical value of the research findings}

Low-temperature pine wood biochar is suitable for increasing the removal efficiency of volatile inorganic pollutants in the biofilter and for increasing water retention in sandy loam. Higher than $500{ }^{\circ} \mathrm{C}$ pyrolysis temperature is suitable for the creation of hydrophilic biochar with a high surface area.

\section{Defended statements}

1. Wood biochar has a higher hydrophilicity and water holding capacity compared to bark biochar due to a lower ash content up to 6 times, which blocks the pore space.

2. 3-fold increase in the specific surface area of biochar enhanced the ammonia removal efficiency by 18 percentage points.

3. Irrespectively of incorporated biochar dose, the sandy loam remained hydrophilic due to surface hydrophilic functional groups.

\section{Approval of the research findings}

Five scientific articles on the topic of the dissertation were published in international journals. Three of them were published in international scientific journals referenced in the Clarivate Analytics Web of Science database and two scientific publications were accepted for publication in an international scientific journals referenced in the Clarivate Analytics Web of Science database.

The results of the research conducted in the dissertation were published at four national conferences and three foreign conferences: 
- In 4 national conferences for young researchers "Science - Future of Lithuania", 2017-2021, in Vilnius.

- In international scientific conference "International Conference on Plant Systems Biology and Biotechnology", 2021, Golden Sands Black Sea resort, Bulgaria.

- In international scientific conference "European Geosciences Union", 2019, Vienna, Austria.

- In international scientific conference "Central and Eastern European Conference on Health and the Environment", 2018, Krakow, Poland.

\section{The structure of the dissertation}

The dissertation consists of an introduction, three chapters and a summary of the results. There are also two annexes.

The volume of the work is 181 pages, excluding annexes, 31 numbered formula, 78 figures, and 32 tables are used in the text. 181 reference entries were used in writing the dissertation.

\section{Increasing the hydrophility of lignocellulosis low temperature biochar and its application in soil, air cleaning technologies}

Lignocellulosic biomass has received a special attention for biochar production in recent decades. Lignocellulosic biomass consists of forestry waste (corn cobs, wheat straw, rice straw), herbaceous plants (e.g. ivory), and arid crops (Kumar et al. 2016). Many studies have shown that lignocellulosic biomass offers great potential due to its abundance as a renewable waste material and its availability. It consists of cellulose (25-50\%), hemicellulose (15-40\%), lignin ( $0-40 \%)$, extracts $(0-15 \%)$, and, usually, a small fraction of inorganic minerals (Kan et al., 2016). The major part of lignocellulosic biomass is cellulose.

Studies have shown that biochar wettability is strongly influenced by the pyrolysis temperature. In one study (Kinney et al., 2012), biochar hydrophobicity decreased with an increasing temperature. For all feedstocks, a higher biochar hydrophobicity was observed at lower temperatures. Biochar hydrophobicity ranged from extremely hydrophobic as was assessed by molarity of ethanol droplet test (MED, 17) for magnolia leaf biochar $\left(300^{\circ} \mathrm{C}\right)$ to hydrophilic ( $\mathrm{MED}=0$ for maize and apple wood biochar, $>500{ }^{\circ} \mathrm{C}$ ). In the case of maize and apple wood biochar, they became hydrophilic $(\mathrm{MED}=0)$ when temperature exceeded $400{ }^{\circ} \mathrm{C}$. The hydrophobicity of magnolia leaf biochar decreased with increasing temperature, but biochar maintained a low hydrophobicity $(\mathrm{MED}=1)$ at temperatures between 500 and $600{ }^{\circ} \mathrm{C}$.

Zornoza et al. (2016) investigated the effects of feedstock properties, pyrolysis temperature, and time on the stability, nutrient content, and wettability of biochar produced from cereal waste. Biochar was produced at $300,400,500$, and $700{ }^{\circ} \mathrm{C}$ for different holding times: 1, 2, 4, and $5 \mathrm{~h}$. The choice of feedstock affected all properties except $\mathrm{pH}$ and wettability. Temperature affected all properties, whereas the holding time had no effect except wettability and thermal stability. Biochar types produced at $300{ }^{\circ} \mathrm{C}$ were strongly 
hydrophobic (>3600 s), and at $500{ }^{\circ} \mathrm{C}$ hydrophobicity disappeared due to loss of aliphatic compounds. At $400{ }^{\circ} \mathrm{C}$ ( 1 and 2 hours) biochar types were strongly hydrophobic (901 s and $>3600 \mathrm{~s}$ ). After 4 hours, cereal waste biochar reduced its degree of hydrophobicity. Above $500{ }^{\circ} \mathrm{C}$, all biochar types became hydrophilic. In another study (Aston et al., 2014), biochar hydrophobicity was influenced by both the feedstock (heather, ivory, spruce) and pyrolysis temperature $\left(350,500,600\right.$, and $\left.800^{\circ} \mathrm{C}\right)$. Biochar hydrophobicity decreased with an increasing temperature, what was associated with both the decomposition of alkyl groups and the retraction of particles during pyrolysis.

In summary, both pyrolysis conditions (both heating time and temperature) and selection of feedstock have a significant influence on changes in lignocellulosic biochar wettability. After 4 and more hours and when pyrolysis temperature increased, the biochar hydrophilicity increased as well. Temperature of $500{ }^{\circ} \mathrm{C}$ is considered to be the boundary from which biochar becomes hydrophilic. The increase of biochar hydrophilicity with increasing temperature is often associated with the decomposition of aliphatic functional groups at higher temperatures. Various sources of lignocellulosic biomass (energetic cereals, forestry waste, organic waste, agricultural waste, etc.) can be used for biochar production. Wood is one of the most important sources for biochar production due to its high potential for usage. Biomass with more lignin and less cellulose has been found to be more suitable for higher biochar yields and porosities.

\section{Determination of biochar physico-chemical properties, modification, capillary rise, its usage in soil and biofiltration}

The Cai et al. (2014) model was chosen as the initial equation for the modelling of the time $(t)$ dependence on capillary rise height $(h)$. The model estimates the time dependence on saturated material mass during the capillary rise process. The model was modified and, instead of a dry capillary radius $r$, an effective capillary radius $\left(r_{e}\right)$ was included, which is equal to the quotient of the swollen capillary square $\left(r_{s}^{\wedge} 2\right)$ and the dry capillary $(r)\left(r_{e}=\right.$ $\left.\left(r_{s}^{\wedge} 2\right) / r\right)$. Therefore, the effective radius $\left(r_{e}\right)$ of the capillary was included in the final form of the new model and, similarly to another study (Shi, Gardner 2000), the volumetric swelling $\left(\delta_{v}\right)$ and the energy recovery coefficient $(C)$ was included. The new model takes the following final form:

$$
m^{2}=\zeta \frac{\rho^{2} A^{2} \phi^{2}\left(S_{w f}-S_{w i}\right)^{2} r_{e} \gamma \cos \theta}{2 \eta} t-\frac{C \delta_{v}}{4 \eta \pi}\left(\frac{r_{s}}{r}\right)^{2} t
$$

here $m$ - saturated mass of material during capillary rise $(\mathrm{g}) ; \phi$ - porosity of material $(\%)$; $\zeta$ - constant of curvature.

The aim of one research was to experimentally evaluate the influence of pyrolysis conditions (temperature, heating time) and lignocellulosic biochar's chemical and physical properties and their relation with wettability and the water holding capacity. A multiple regression analysis was performed using Origin 2018b program for determination of relationship between the properties. Pine and birch bark, pine and birch wood, hemp were heated at 300, 350, 400, 450, 500, 550, 600, 650, $700{ }^{\circ} \mathrm{C}$ temperatures and 2 hours holding time in a muffle furnace (SNOL, E5CK-T). Feedstocks were wrapped into aluminium foil due to the creation of oxygen deficiency conditions (Baltrènaitè et al., 2017). The yield of 
biochar is expressed as a percentage by dry weight (Naeem et al., 2014). To determine the ash content, the crucible with the sample was weighed and placed in the oven. The sample was heated to $550{ }^{\circ} \mathrm{C}$ for 1 hour. The mass remaining after heating was expressed as the mass of ash (Sun et al., 2017). The $\mathrm{pH}$ was adjusted in $0.01 \mathrm{M} \mathrm{CaCl}_{2}$ in a ratio of 1:5, which after $1 \mathrm{~h}$ of shaking was determined using a Mettler Toledo Seven Multi $\mathrm{pH}$ meter. The electrical conductivity was determined in a mixture of biochar and deionized water in a ratio of 1:10 with a conductometer (EBC 2012). The elemental composition $(\mathrm{C}, \mathrm{H}, \mathrm{N}, \mathrm{O})$ of the biochar samples was determined using a EuroEA3000-Single analyser (EBC 2012). The $\mathrm{N}_{2}$-Brunauer-Emmett-Teller (BET) theory was used to calculate the specific surface area (SSA) (Baltrènas et al., 2016). Functional groups were evaluated by Fourier transfer infrared spectroscopy (FTIR) at wavelengths between 450 and $4000 \mathrm{~cm}^{-1}$ (Huang et al., 2017).

The aim of the biochar wettability study was to determine its wettability for different types of biochar using different methods (water droplet penetration time test (WDPT), MED, and contact angle analysis) and to determine linear correlation between wettability results based on Pearson correlation analysis using software Statistica10. The WDPT procedure consists of dropping a water droplet on the biochar surface and estimating the time for complete penetration (Kinney et al., 2012). Seven concentrations of ethanol solutions $(0,3,5,11,13,18,24$, and $36 \%$ ) were used in the MED test and their sorption on the biochar surface over $3 \mathrm{~s}$ was evaluated. MED values are categorized from 1 (highly hydrophilic) to 7 (extremely hydrophobic), when a $0 \%$ ethanol value corresponds to a highly hydrophilic and a $36 \%$ ethanol value corresponds to an extremely hydrophobic substance (Page-Dumroese et al., 2015). The degree of a contact angle of the water droplet lowered on the biochar surface was measured by the Sessile Drop method. Droplet profile photos were taken using an Alcatel Idol-4 camera. Photos were analysed using ImageJ with the DropSnake droplet analysis plug-in (Jeffery et al., 2015).

The aim of the biochar modification study was to alter low-temperature birch bark biochar hydrophobicity based on different physical and chemical methods. For physical modification, biochar was mechanically exposed (crushed) and activated by the steam of different solutions (rainwater, rhamnolipid solution $(5,20$, and $40 \mathrm{mg} / \mathrm{l})$ ) to increase its microporosity and the content of oxygen-containing functional groups. Nitric acid was used for chemical modification due to formation of oxygen and nitrogen-containing functional groups that are important for the adsorption of contaminants. Biochar was produced from birch bark under anaerobic conditions at $450{ }^{\circ} \mathrm{C}$ and $2 \mathrm{~h}$ holding time in a pipe type furnace (SNOL 0.7/1250). Biochar was then crushed and fractionated using a sieving method (Retsch, $1.6 \mathrm{~mm}, 900 \mu \mathrm{m}$ and $300 \mu \mathrm{m}$ sieves). The biochar fractions were selected on the basis of another study (Liu et al., 2017). Wettability, functional groups, and structural properties of biochar were evaluated by the methods described in Section 2. Rainwater for the modification was collected at the Aukštaitija complex monitoring station located in Rūgšteliškis village, Utena district. A biochar hydrophilicity enhancement device was used for its modification (Baltrènas et al., 2019). For chemical modification, $1.0 \mathrm{~g}$ of dried powdered biochar was treated with $25 \mathrm{ml}$ of 20,40 , and $65 \%$ of $\mathrm{HNO}_{3}$ solution at $80{ }^{\circ} \mathrm{C}$ (Guzel et al., 2017).

The biofiltration study evaluated the efficiency of steam-modified pine wood biochar for the removal of volatile organic (acetone, xylene) and inorganic (ammonia) compounds. 
Since steam-modified biochar is more wettable, more microporous, and has a larger surface area, it is likely that such biochar will be more efficient in removing hydrophilic polar compounds from the air. Biofilter consisted of two inlet and outlet tubes and a reservoir containing 86 plexiglass tubes filled with biocharge of pine wood biochar and wood fiber. A biochar hydrophilicity enhancement device was used for its modification by steam of $20 \mathrm{mg} / \mathrm{l}$ rhamnolipid solution (Baltrènas et al., 2019). The air flow rate in the biofilter was controlled using an inlet valve. To ensure capillary irrigation of the biocharge, the filled tubes were immersed in a solution of nutrients (dicalcium phosphate, potassium chloride, magnesium sulfate, ferrous sulfate, and sodium nitrate). The relative humidity and temperature at the biofilter were assessed using a moisture meter M0290. The moisture content of biocharge was assessed by the weighting method (Zagorskis et al., 2012). The biocharge was activated by the steam of all compounds $\left(20 \mathrm{mg} / \mathrm{m}^{3}\right)$ for 2 weeks, after which the efficiency of biofilter air purification was monitored. The steam of $300 \mathrm{mg} / \mathrm{m}^{3}$ of acetone xylene and ammonia were periodically fed to the biofilter for 5 days. Contaminant concentrations were determined with a photoionization detector, a MiniRAE 2000 instrument (American RaeSystems company) at two points (for $5 \mathrm{~min}$.). The cleaning efficiency of biofilter was calculated according to the formula (Baltrènas et al., 2015).

The aim of soil amended with biochar study was to determine the influence of time, tillage-fertilization system and pine wood biochar $\left(450{ }^{\circ} \mathrm{C}, 2 \mathrm{~h}\right)$ dose on soil wettability changes for sandy light loam. The studied soil had the highest amount of sand particles $(53.7 \%)$, on the average, dust particles $(32.6 \%)$ and, at least, clay particles $(13.7 \%)$. Effects of tillage (plougless shallow tillage, direct drilling), fertilization (with NPK fertilizers and without them), and biochar dose (0,5 and $15 \mathrm{t} / \mathrm{ha})$ were investigated. Soil samples were collected from a $15 \mathrm{~cm}$ layer of soil at two times -3 and 6 months after the start of the experiment. Soil wettability was assessed using the WDPT test. The properties of biochar (wettability, elemental composition, cation exchange capacity, $\mathrm{pH}$, concentrations of potentially toxic elements, etc.) were assessed. To determine significant differences between the combinations of studied factors on soil physico-chemical properties, a threeway ANOVA analysis was performed (STATISTICA 6.0).

A 2D model with a rectangular geometry with a length of $12.5 \mathrm{~cm}$ and a width of 2 $\mathrm{cm}$ was chosen for the computational capillary rise in biochar modelling. The model has three main assumptions, that there are three phases: water, air, and porous matrix. The Brooks and Corey model for capillary pressure and relative conductivity is used for timedependent modelling.

\section{Results of theoretical and experimental investigations of biochar wettability}

Compared all compounds, hexane had the highest capillary rise height, which was $26 \mathrm{~cm}$ after $8 \mathrm{~h}$ from the beginning of the experiment (Fig. S3.1). This solution had the lowest surface tension $(0.02 \mathrm{~N} / \mathrm{m})$ and dynamic viscosity $\left(0.14 \mathrm{mN} \cdot \mathrm{s} / \mathrm{m}^{2}\right)$. Meanwhile, water and ammonia had the lowest rise height $(9.87$ and $11.8 \mathrm{~cm}$ after $8 \mathrm{~h}$, respectively). This may be attributed to the surface tensions of the solutions, which were 0.07 and $0.08 \mathrm{~N} / \mathrm{m}$ for water and ammonia, respectively. 


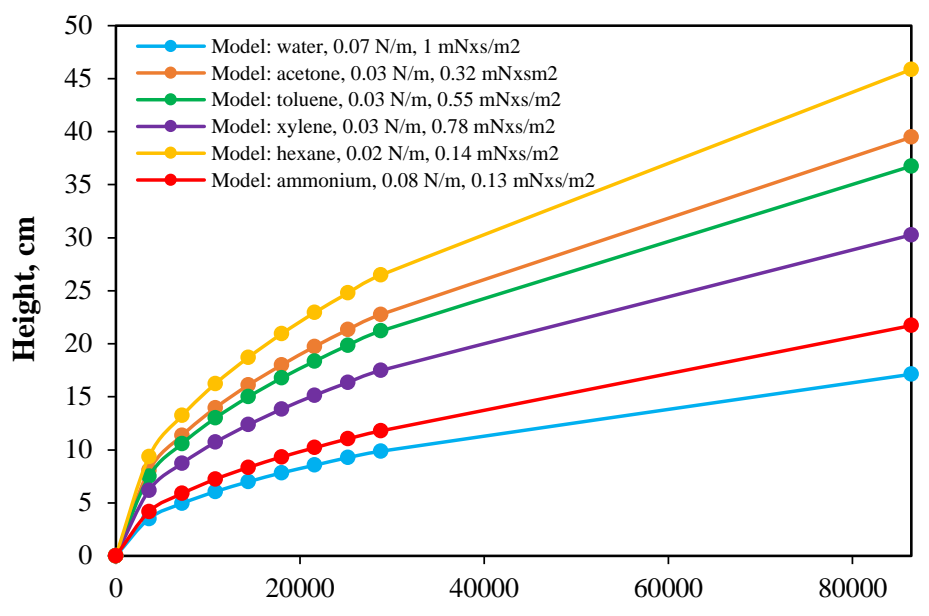

Time, $\mathbf{s}$

Fig. S3.1. Modelling results of capillary rise rate $(\mathrm{cm} / \mathrm{s})$ depending on the solution properties (surface tension and dynamic viscosity) based on the modified Lucas-Washburn model, $n=3$

In summary, the surface tension of a liquid is a parameter that strongly affects its capillary rise height in a vertical tube filled with biochar, because the lower it is, the higher the capillary rise height. Besides, the lower the Henry's constant of a compound, the higher the capillary rise. The capillary rise heights for different volatile organic compounds, depending on their Henry's constants, are in the following order: acetone $(h(8)=22.8 \mathrm{~cm}$, $\left.\mathrm{K}_{\mathrm{H}}=0.00159\right)>$ toluene $\left(h(8)=21.2 \mathrm{~cm}, \mathrm{~K}_{\mathrm{H}}=0.235\right)>$ xylene $\left(h(8)=17.49 \mathrm{~cm}, \mathrm{~K}_{\mathrm{H}}=\right.$ $0.3)$.

Based on the obtained FTIR results, all biochar types were characterized by amine functional groups $\left(3300-3500 \mathrm{~cm}^{-1}\right)$, alkanes $(\mathrm{CH})\left(2850-3000 \mathrm{~cm}^{-1}\right)$, acidic $(1680-$ $\left.1700 \mathrm{~cm}^{-1} ; 1700-1730 \mathrm{~cm}^{-1} ; 1715-1740 \mathrm{~cm}^{-1}\right)$, aromatic $\mathrm{C}=\mathrm{C}\left(1400-1600 \mathrm{~cm}^{-1} ; 1550\right.$ $\left.1640 \mathrm{~cm}^{-1}\right)$, anhydride $\left(1150-1350 \mathrm{~cm}^{-1}\right)$, and C-H $\left(880-900 \mathrm{~cm}^{-1} ; 790-840 \mathrm{~cm}^{-1} ; 750-\right.$ $810 \mathrm{~cm}^{-1}$ ) (Fig. S3.2). O-H functional groups (3500-3700 $\mathrm{cm}^{-1}$ ) were present in all biochar types, except for birch bark. All $300{ }^{\circ} \mathrm{C}$ biochar types had a slight absorption peak at $2850 \mathrm{~cm}^{-1}$ indicating the existence of aliphatic functional groups. The presence of these groups in low-temperature biochar results in its low wettability.

According to the structural analysis, as temperature increased, biochar's specific surface area and total pore volume increased, but its average pore size decreased. A sudden increase in the surface area was observed from 400 to $500{ }^{\circ} \mathrm{C}$, which was the largest in the case of pine bark biochar - up to 191 times. The pore volume increased mainly in the case of pine bark biochar, which was 19 times higher at 500 and $600{ }^{\circ} \mathrm{C}$. The sudden increase in surface area and pore volume above $500{ }^{\circ} \mathrm{C}$ is due to the decomposition of lignin and the release of $\mathrm{H}_{2}$ and $\mathrm{CH}_{4}$ gases from the biochar structure. 

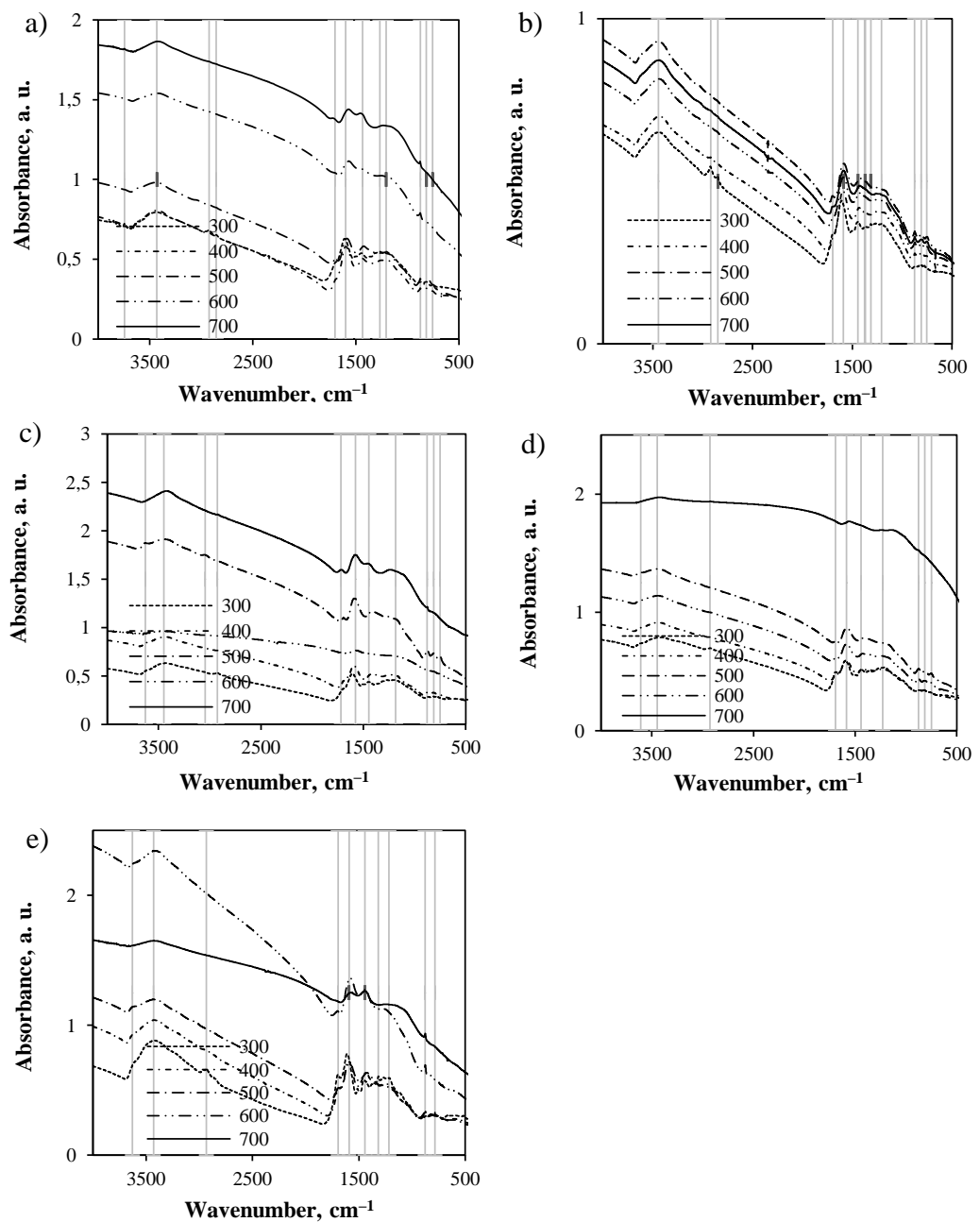

Fig. S3.2. Dependence of surface functional groups of biochar on pyrolysis temperature based on the Fourier-transform infrared spectra: a) pine bark; b) birch bark; c) pine wood; d) birch wood; e) hemp, $n=2$

According to WDPT results, pine and birch bark biochar types were less hydrophilic compared to wood or hemp. These types of biochar lost their extreme hydrophobicity only at $600{ }^{\circ} \mathrm{C}$, while pine wood and hemp biochar at a relatively low temperature of $300{ }^{\circ} \mathrm{C}$ and $350{ }^{\circ} \mathrm{C}$ (WDPT from $8340 \mathrm{~s}$ to $14.1 \mathrm{~s}$ for hemp and from $2945 \mathrm{~s}$ to $3.53 \mathrm{~s}$ for pine wood). Meanwhile, birch wood biochar maintained slight hydrophobicity (WDPT from $2.47 \mathrm{~s}$ to $2.33 \mathrm{~s}$ ) throughout the whole temperature range (Fig. S3.3). 


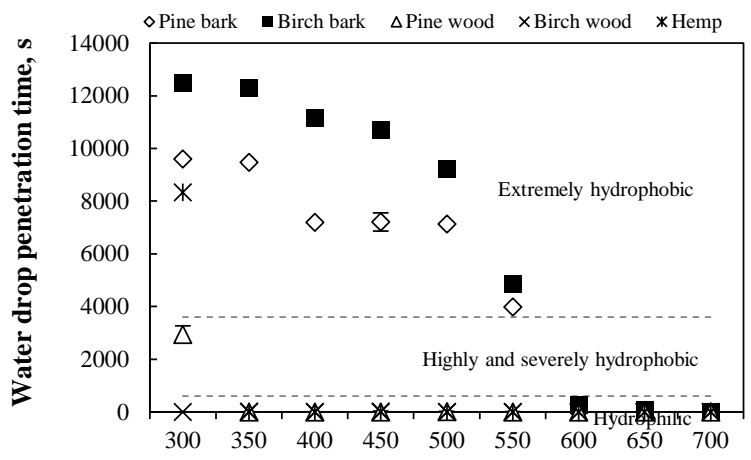

Pyrolysis temperature, ${ }^{\circ} \mathrm{C}$

Fig. S3.3. Wettability of lignocellulosic biochar types, $n=3$

Based on a multiple regression analysis, the following equations were obtained for the prediction of biochar water holding capacity (Equation S3.1) and wettability (Equation S3.2):

$$
\begin{gathered}
Y=1.508+(0.27 \times A C) \\
\log (Y)=0.796-(2.13 \times \log (A P S)),
\end{gathered}
$$

here $A C$ - ash content of biochar, \%; $A P S$ - average pore size of biochar, $\mathrm{nm}$.

Table S3.1. Results of multiple regression analysis for biochar $(n=14)$

\begin{tabular}{|l|l|l|l|l|}
\hline Dependent variable & \multicolumn{1}{|c|}{ Independent variable } & \multicolumn{1}{|c|}{$R^{2}$} & \multicolumn{1}{|c|}{$p$} \\
\hline $\begin{array}{l}\text { Water holding } \\
\text { capacity }\end{array}$ & Ash content & 0.77 & 22.9 & 0.001 \\
\hline Wettability & Average pore size & 0.54 & 8.16 & 0.024 \\
\hline
\end{tabular}

The water holding capacity (by times) of biochar can be predicted based on its ash content. A high coefficient of determination $R_{2}(=0.77)$ and $p$ value of the model is less than 0.05 ( $p=0.001)$ mean that the model is good because it explains $77 \%$ of the scatter of the dependent variable about its mean. Meanwhile, biochar wettability (s) can be predicted based on the average pore size of the biochar. A higher than average coefficient of determination $R_{2}(=0.54)$ and $p(=0.024)$ means that the model is good because it explains $54 \%$ of the scatter of the dependent variable about its mean. The feedstock (bark) with more ash usually has a lower surface area compared to the raw material (wood) with a lower ash content. Meanwhile, decreasing pore sizes increase the physical adsorption of water as the pyrolysis temperature increases. Low-temperature types of biochar have a lower surface area and porosity due to the effect of pore clogging with tars, which reduces the attraction 
of biochar to water. The average pore size decreased with an increasing temperature, and this is best seen in the case of hemp biochar (4.54 to $1.13 \mathrm{~nm}$ ).

Based on the wettability estimation using different tests, the water droplet penetration time test is the most suitable for biochar, as the obtained results showed the largest variation of biochar wettability (Fig. S3.4) depending on the feedstock and pyrolysis conditions compared to ethanol droplet molarity test and contact angle analysis.

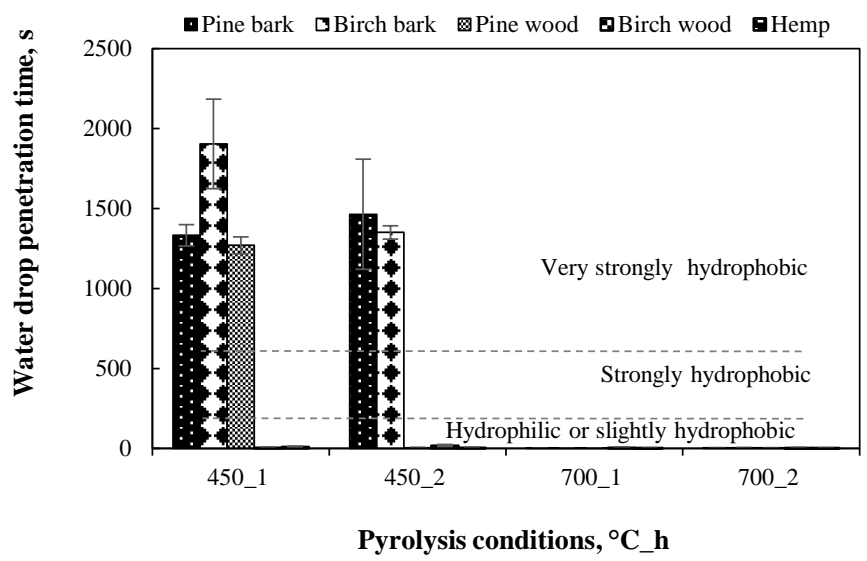

Fig. S3.4. Water droplet penetration time for lignocellulosic biochar types $(n=3)$

Wettability of biochar ranged from hydrophilic to strongly hydrophobic. Lowtemperature $\left(450{ }^{\circ} \mathrm{C}\right)$ biochar types made from almost all feedstocks (except pine wood, birch wood, and hemp biochar) were characterized by high hydrophobicity (600-3600 s substrate is very hydrophobic). According to WDPT, the highest hydrophobicity had birch bark biochar $\left(450^{\circ} \mathrm{C}, 1 \mathrm{~h}\right)$, whose WDPT reached 1904 s. Meanwhile, all other hightemperature $\left(700^{\circ} \mathrm{C}\right)$ biochar types showed hydrophilicity or slight hydrophobicity (WDPT from 1 to $4 \mathrm{~s})$. Hydrophilicity is associated with lower contact angles $\left(76^{\circ}\right.$, pine wood, $\left.700{ }^{\circ} \mathrm{C}, 1 \mathrm{~h}\right)$ and hydrophobicity with higher angles $\left(107^{\circ}\right.$, birch bark, $\left.450{ }^{\circ} \mathrm{C}, 1 \mathrm{~h}\right)$. Although biochar wettability is easier to assess using the water droplet penetration time test or the ethanol droplet molarity test, they have little scientific value. Information of the physical processes between biochar and water droplet, such as the critical surface tension of solids, can be obtained from the contact angle analysis.

Steam-modified birch bark biochar from different solutions had higher hydrophilicity compared to unmodified biochar, but after modification it retained its high initial hydrophobicity (Fig. S3.5). Comparing the effect of steam from different solutions, rainwater had the greatest effect, as wettability increased 12-fold compared to the unmodified. Meanwhile, exposure to the lowest concentration (20\%) of nitric acid solution increased biochar wettability about 5 times. It showed that steam activation was a suitable way to modify biochar and to increase its wettability. 


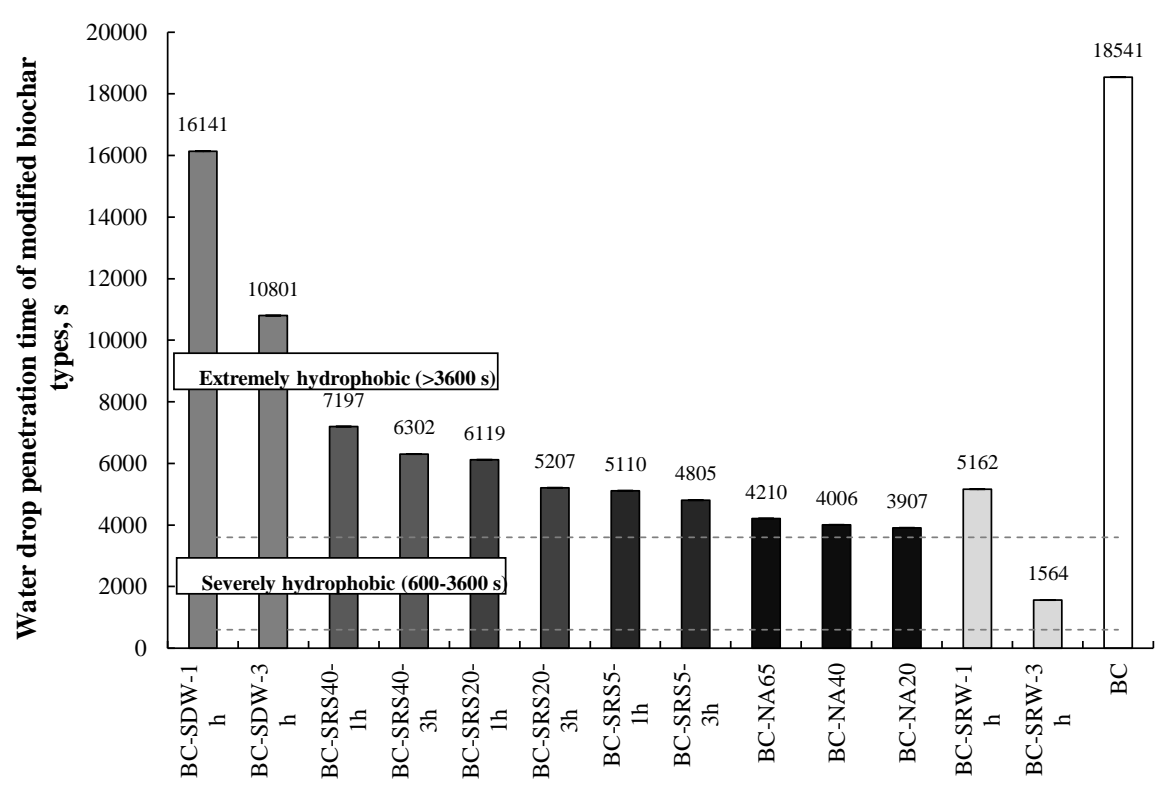

Fig. S3.5. Dependence of birch bark biochar wettability (s) on different modification methods: BC - unmodified biochar; BC-SDW-1h - modified for $1 \mathrm{~h}$ with deionized water vapor; BC-SDW-

$3 \mathrm{~h}-$ modified for $3 \mathrm{~h}$ deionized water vapor; BC-SRS40-1h - modified 1 hour rhamnolipid (40 mg/l) solution steam; BC-SRS40-3h - modified 3 hours rhamnolipid (40 mg/l) solution steam; BC-SRS20-1h - modified with steam for 1 hour of rhamnolipid $(20 \mathrm{mg} / \mathrm{l})$ solution; BC-SRS20$3 \mathrm{~h}$ - modified with steam of 3 hours of rhamnolipid (20 mg/l) solution; BC-SRS5- $1 \mathrm{~h}$ - modified with steam of 1 hour of rhamnolipid $(5 \mathrm{mg} / \mathrm{l})$ ) solution steam; BC-SRS5-3h - modified for 3 hours with rhamnolipid (5 mg/l) solution steam; BC-NA20 - modified with $20 \%$ nitric acid solution; BC-NA40 - modified with $40 \%$ nitric acid solution; BC-NA65 - modified with $65 \%$ nitric acid solution; BC-SRW-1h - modified with natural acid solution for 1 hour; BC-SRW-3h modified with natural acid solution for 1 hour, $n=3, \pm$ standard deviation

To evaluate the effect of the modification on the biochar functional groups, the modification with $20 \mathrm{mg} / \mathrm{l}$ rhamnolipid solution (for $1 \mathrm{~h}$ ) formed maximum absorption intensities of aromatic $\mathrm{C}=\mathrm{C}\left(1431 \mathrm{~cm}^{-1}\right)$ and $\mathrm{C}-\mathrm{H}\left(876 \mathrm{~cm}^{-1}\right)$ groups. The weak peak at $2923 \mathrm{~cm}^{-1}$ indicates an aliphatic $\mathrm{C}-\mathrm{H}$ bond that did not disappear after the steam modification, indicating that the aliphatic structure is resistant to heat and water. After modification with nitric acid solutions, peaks were found at $3411 \mathrm{~cm}^{-1}$ (hydroxyl-OH functional groups), $1606 \mathrm{~cm}^{-1}\left(\mathrm{C}=\mathrm{O}, \mathrm{C}=\mathrm{C}\right.$ and $\mathrm{C}=\mathrm{N}$ groups) and $1385 \mathrm{~cm}^{-1}(\mathrm{~N}=\mathrm{O}$ group) wavenumbers. The formation of oxidative functional groups (such as carbonyl, hydroxyl and carboxyl) on the biochar surface after modification by steam and nitric acid solution increases its hydrophilicity, thus improving the adsorption of the pollutants in water systems. 
Assessing different modification methods, it can be seen that the steam of $20 \mathrm{mg} / \mathrm{l}$ rhamnolipid solution had the greatest effect on the development of biochar surface area which was $15.2 \mathrm{~m}^{2} / \mathrm{g}$ after $1 \mathrm{~h}$ duration of exposure. Similarly, the above modification resulted in the biochar micropores' surface area $\left(14.4 \mathrm{~m}^{2} / \mathrm{g}\right)$. This indicates that the majority of the pores in modified biochar were micropores (up to $95 \%$ of the total area was micropore area). Biochar has a large surface area due to the microporous structure, which provides a good adsorptive capacity for contaminants and survival of microorganisms in the biofilter.

The steam modified biochar with the rhamnolipid solution can efficiently remove acetone, xylene, and ammonia at removal efficiencies of 93\%, 72\%, and 96\%, respectively. Significantly higher removal efficiency (up to 17.6 percentage points) were observed for ammonia (Fig. S3.6).

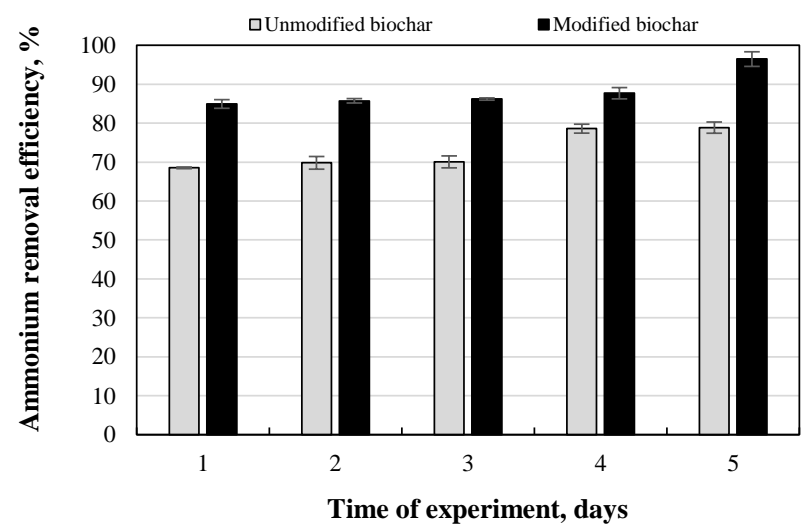

Fig. S3.6. Time dependence of efficiency of pollutant removal in a biofilter filled with a mixture of unmodified biochar and fiber and a mixture of steam modified biochar and fiber to which an air stream contaminated with ammonia vapor was supplied, $n=3$

Thus, it can be argued that steam modified biochar is more efficient in removing volatile inorganic polar compounds compared to organic polar and non-polar compounds. Modified biochar had up to 8 percentage points higher moisture content (67\%), which can be explained by a higher average pore radius $(22 \mu \mathrm{m})$. When the radius of the capillary (pore) is larger, the capillary process is faster. The lower efficiency of xylene removal compared to other pollutants can be attributed to its non-polarity and higher Henry's constant $\left(7.18 \cdot 10^{-3} \mathrm{~atm}-\mathrm{m}^{3} / \mathrm{mol}\right)$.

Tested sandy loam soil irrespectively of investigation date, soil tillage-fertilization system, and biochar dose remained hydrophilic (WDPT $\leq 1 \mathrm{~s}$ ). The tendency of hydrophilicity of soil depended on the results of molecular spectrometry which showed the presence of kaolinite (peaks at 3626 and $3416 \mathrm{~cm}^{-1}$ wavenumbers) and aluminosilicate minerals in its structure (Fig. S3.7). Kaolinite is initially hydrophilic and -OH group is the main factor contributing to its high attraction to water. Silicates are characterized by the hydrophilicity whose main unit ( $\mathrm{Si}-\mathrm{O}$ group) was found in the tested soil FTIR spectra (peaks at 1023 and $466 \mathrm{~cm}^{-1}$ wavenumbers). Though pine wood biochar, which was 
incorporated into the soil, was hydrophobic (1810 s), agricultural soil remained hydrophilic irrespective of biochar dose. It can be related with a natural effect of abiotic factors (precipitation and temperature), which renders biochar hydrophobicity. Higher biochar hydrophobicity $\mathrm{r}$ can be related with its higher ash content (16.6\%), lower oxygen content (3.39\%), and specific surface area $\left(2.77 \mathrm{~m}^{2} / \mathrm{g}\right)$ compared to other low-temperature biochar types. Feedstocks having higher ash contents most usually have lower surface area compared to the feedstocks having lower ash content, since ashes block the pore space.
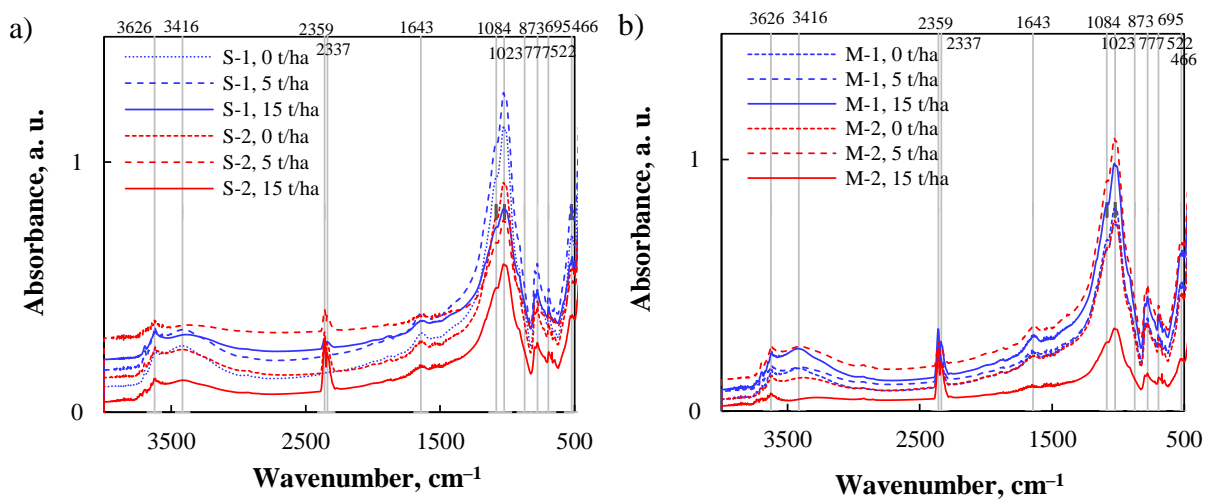

Fig. S3.7. Influence of biochar on soil surface functional groups in different tillage-fertilization systems after 3 months from the beginning of the experiment: a) $\mathrm{S}$ - ploughless shallow tillage,

b) M - direct drilling, 1 - unfertilized, 2 - fertilized, $n=2$

Intensity of soil's hydrophilic functional groups $(\mathrm{C}-\mathrm{O})$ correlated with the organic matter content. An average negative correlation $(r=-0.59)$ was obtained between the mentioned parameters. It shows that a lower soil's organic matter content can be characterized by the higher amount of hydrophilic functional groups, therefore soils having a higher organic matter content will have higher hydrophobicity. Direct drilling improved soil's physical-chemical properties: water holding capacity, moisture content, $\mathrm{pH}$, and organic matter content. Direct drilling, fertilization with NPK fertilizers and $15 \mathrm{t} / \mathrm{ha}$ biochar dose increased the water holding capacity by $32.5 \%$, and $\mathrm{pH}$ by $17.6 \%$ after 3 months from biochar application. After 6 months, the same soil management practice caused increase in moisture content by $304 \%$ and organic matter content by 6.21 percent units.

\section{General conclusions}

1. Based on the results of the modified Lucas-Washburn model and experiment water capillary rise rate using the modified Lucas-Washburn model, which includes composite parameter, energy loss coefficient, volumetric swelling and swollen capillary radius, can be used to predict a short-term (up to $5 \mathrm{~h}$ ) capillary rise rate in biochar.

2. Hemp biochar is characterized having higher water capillary rise compared to other feedstocks, which after 8 hours reaches 8.67 and $10 \mathrm{~cm}$ experimentally and based on the modified Lucas-Washburn model, respectively. This is associated with the higher porosity 
of the material $(86 \%)$, average capillary radius $\left(1.48 \cdot 10^{-5} \mathrm{~m}\right)$, and wettability $\left(65^{\circ}\right)$. The finest biochar $(<300 \mu \mathrm{m})$ had a higher rise height of 9.5 and $10.2 \mathrm{~cm}$, respectively. This could be due to higher porosity $(82 \%)$, wettability $\left(79^{\circ}\right)$, and volumetric swelling $(5 \%)$.

3. As the temperature increases from $300{ }^{\circ} \mathrm{C}$ to $700{ }^{\circ} \mathrm{C}$, biochar's $\mathrm{pH}$, electrical conductivity, ash content, water holding capacity, $\mathrm{C}$ content, specific surface area, total and micropore volume, and wettability increases. Meanwhile, yields, O, H, N contents, average pore size, and organic functional groups decreases. Hydrophilic biochar is produced at temperatures above $500{ }^{\circ} \mathrm{C}$ due to a sudden increase in a specific surface area and evaporation of aliphatic groups.

4. The hydrophobicity of biochar is lost at different temperatures depending on the feedstock: in the case of birch wood and hemp it disappears at a low temperature $\left(300^{\circ} \mathrm{C}\right.$ and $350{ }^{\circ} \mathrm{C}$ ), and in the case of bark it is most resistant and disappears only at $600{ }^{\circ} \mathrm{C}$. This is due to the different biochemical composition of the biomass (amount of cellulose, hemicellulose, and lignin components).

5. Birch wood biochar is the most hydrophilic because it has the lowest water droplet penetration time (from 2.47 to $2.33 \mathrm{~s}$ ) in the whole temperature range. Pine and birch bark biochar $\left(300{ }^{\circ} \mathrm{C}\right)$ are characterized by extreme hydrophobicity $(12,480$ and $9600 \mathrm{~s}$, respectively) which is associated with lipophilic compounds found in the initial material (up to 20\%). Multiple regression analysis showed that $77 \%$ of the variation of biochar water holding capacity can be predicted based on its ash content and $54 \%$ of its wettability variation depending on the average pore size.

6. Pearson correlation analysis showed the suitability of all three methods for the assessment of biochar wettability due to strong or very strong correlation. The water droplet penetration time test is considered the most appropriate because the wettability of different types of biochar gaines a wide variation (from hydrophilic (1 s) to very hydrophobic (1904 s)), which was not shown by other tests. Hydrophilicity is associated with lower contact angles $\left(75.8^{\circ}\right.$, pine wood, $\left.700^{\circ} \mathrm{C}\right)$ and hydrophobicity with higher angles $\left(107^{\circ}\right.$, birch bark, $\left.450{ }^{\circ} \mathrm{C}\right)$.

7. As the biochar fraction decreases, wettability of the biochar increases as well and is the highest ( $3 \mathrm{~s})$ at $<300 \mu \mathrm{m}$. The effect of the steam of rhamnolipid solution $(20 \mathrm{mg} / \mathrm{l})$ has the largest effect on the increase of biochar surface area $\left(15.2 \mathrm{~m}^{2} / \mathrm{g}\right)$. The majority of the pores in this type of biochar are micropores (up to $95 \%$ of the micropore area is the total area). The modification results in the highest absorption intensities of such functional groups as hydroxyl $\left(3421 \mathrm{~cm}^{-1}\right)$, carboxylic $\mathrm{C}=\mathrm{O}\left(1599 \mathrm{~cm}^{-1}\right)$, aromatic $\mathrm{C}=\mathrm{C}\left(1431 \mathrm{~cm}^{-1}\right)$, aromatic $\mathrm{C}-\mathrm{H}\left(876 \mathrm{~cm}^{-1}\right)$, the formation of which increases the hydrophilicity of biochar.

8. Biochar modified with $20 \%$ nitric acid solution has the highest wettability (3907 s), specific surface area $\left(4.36 \mathrm{~m}^{2} / \mathrm{g}\right)$, micropore volume $\left(0.0008 \mathrm{~cm}^{3} / \mathrm{g}\right)$, and development of oxygen-nitrogen functional groups compared to biochar modified with $40 \%$ and $65 \%$ nitric acid solutions: peaks at $3411 \mathrm{~cm}^{-1}, 1606 \mathrm{~cm}^{-1}$, and $1385 \mathrm{~cm}^{-1}$ wavelengths.

9. The usage of steam-modified biochar with rhamnolipid solution and wood fiber biocharge achieves higher removal efficiencies of acetone, xylene, and ammonia compounds, especially with respect to polar ammonia (93\%, 72\% and 96\%, respectively). The ammonia removal efficiency of the biofilter increases up to 17.6 percentage points compared to unmodified biochar. 
10. The studied sandy loam, regardless of the study time, tillage-fertilization system and biochar application rate, is characterized by hydrophilicity (WDPT $\leq 1 \mathrm{~s}$ ), which can be related to kaolinite (peaks at 3626 and $3416 \mathrm{~cm}^{-1}$ wavelengths) and aluminosilicates minerals (peaks at 1023 and $466 \mathrm{~cm}^{-1}$ wavelengths) that are inherently hydrophilic. Usage of direct sowing, fertilization with mineral fertilizers, and the $15 \mathrm{t} / \mathrm{ha}$ biochar dose, after 3 months increases the soil water holding capacity $(32.5 \%)$ and $\mathrm{pH}(17.6 \%)$, and after 6 months it increases the moisture content (304\%) and organic matter content $(62.6 \%)$.

\section{Recommendations}

1. In order to obtain hydrophilic biochar, it is recommended to produce it at temperature higher than $500{ }^{\circ} \mathrm{C}$. This is the limit beyond which the surface area of the biochar increases significantly (up to 38 times in the case of pine wood biochar) and the aliphatic functional group disappears (peak at $2850 \mathrm{~cm}^{-1}$ ) compared to biochar made at $400{ }^{\circ} \mathrm{C}$. Wood (pine or birch) biochar has higher wettability, specific surface area, micropore volume and lower ash content, which makes such biochar more suitable for sorption of volatile pollutants compared to bark biochar.

2. It is proposed to modify biochar by the steam of $20 \mathrm{mg} / \mathrm{l}$ of rhamnolipid solution for 1 hour in a biochar hydrophilicity enhancement device because such biochar has a higher total specific surface area and a micropore surface area which are required for the sorption of ammonia from the polluted air stream.

3. Direct sowing, fertilization with mineral nitrogen, phosphorus and potassium fertilizers, and biochar application dose of $15 \mathrm{t} / \mathrm{ha}$ are suitable for increasing soil water holding capacity (32.5\%), $\mathrm{pH}(17.6 \%)$, moisture content $(304 \%)$, and organic matter content $(62.6 \%)$. 
Priedai $^{3}$

A priedas. Disertacijos autorès sąžiningumo deklaracija B priedas. Autorès mokslinių publikacijų disertacijos tema kopijos

${ }^{3}$ Priedai pateikiami pridètoje kompaktinèje plokštelèje. 


\section{Luiza USEVIČIŪTÉ \\ LIGNOCELIULIOZINĖS ŽEMATEMPERATŪRĖS BIOANGLIES HIDROFILIŠKUMO DIDINIMO TYRIMAI IR TECHNOLOGIJOS KŪRIMAS}

Daktaro disertacija

Technologijos mokslai, aplinkos inžinerija (T 004)

INVESTIGATIONS AND TECHNOLOGY DEVELOPMENT OF HYDROPHILICITY ENHANCEMENT OF LIGNOCELLULOSIC LOW TEMPERATURE BIOCHAR

Doctoral Dissertation

Technological Sciences,

Environmental Engineering (T 004)

202110 11. 17,3 sp. I. Tiražas 20 egz.

Leidinio el. versija https://doi.org/10.20334/2021-044-M

Vilniaus Gedimino technikos universitetas

Saulètekio al. 11, 10223 Vilnius

Spausdino BI UAB „Baltijos kopija“,

Kareivių g. 13B, 09109 Vilnius 